\title{
A Retrospective Analysis of Energy Use and \\ Conservation Trends: 1972-1982
}

\section{Appendix}
R. C. Adams
D. H. Lax
D. B. Belzer
R. J. Moe
J. M. Fang
J. M. Roop
K. L. Imhoff
A. R. Wusterbarth

June 1985

Prepared for the U.S. Department of Energy under Contract DE-AC06-76RLO 1830

Pacific Northwest Laboratory

Operated for the U.S. Department of Energy

by Battelle Memorial Institute 


\section{DISCLAIMER}

This report was prepared as an account of work sponsored by an agency of the United States Government. Neither the United States Government nor any agency thereof, nor any of their employees, makes any warranty, express or implied, or assumes any legal liability or responsibility for the accuracy, completeness, or usefulness of any information, apparatus, product, or process disclosed, or represents that its use would not infringe privately owned rights. Reference herein to any specific commercial product, process, or service by trade name, trademark, manufacturer, or otherwise, does not necessarily constitute or imply its endorsement, recommendation, or favoring by the United States Government or any agency thereof. The views and opinions of authors expressed herein do not necessarily state or reflect those of the United States Government or any agency thereof.

\section{PACIFIC NORTHWEST LABORATORY operated by \\ BATTELLE \\ for the \\ UNITED STATES DEPARTMENT OF ENERGY \\ under Contract DE-AC06-76RLO 1830}

\begin{tabular}{|c|c|}
\hline \multirow{2}{*}{\multicolumn{2}{|c|}{ Printed in the United States of America }} \\
\hline & \\
\hline \multicolumn{2}{|c|}{$\begin{array}{l}\text { Available from } \\
\text { National Technical information Service }\end{array}$} \\
\hline \multicolumn{2}{|c|}{ United States Department of Commerce } \\
\hline \multirow{2}{*}{\multicolumn{2}{|c|}{$\begin{array}{c}5285 \text { Port Royal Road } \\
\text { Springfield, Virginia } 22161\end{array}$}} \\
\hline & \\
\hline \multirow{2}{*}{\multicolumn{2}{|c|}{$\begin{array}{l}\text { NTIS Price Codes } \\
\text { Microfiche A01 }\end{array}$}} \\
\hline & \\
\hline \multicolumn{2}{|c|}{ Printed Copy } \\
\hline & Price \\
\hline Pages & Codes \\
\hline $001-025$ & $\mathrm{AO2}$ \\
\hline $026-050$ & $\mathrm{A03}$ \\
\hline $051-075$ & $\mathrm{~A} 04$ \\
\hline $076-100$ & A05 \\
\hline $101-125$ & $A 06$ \\
\hline $126 \cdot 150$ & $\mathrm{~A} 07$ \\
\hline $151-175$ & $\mathrm{~A} 0 \mathrm{~B}$ \\
\hline $176-200$ & $A 09$ \\
\hline $201-225$ & $A 010$ \\
\hline $226-250$ & A011 \\
\hline $251-275$ & $A 012$ \\
\hline $276-300$ & $A 013$ \\
\hline
\end{tabular}




\title{
A RETROSPECTIVE ANALYSIS OF ENERGY USE AND CONSERVATION TRENDS: 1972-1982 \\ APPENDIX
}

\author{
R.C. Adams \\ D.B. Belzer \\ J.M. Fang \\ K.L. Imhqff
D.H. Lax \\ R.J. Moe \\ J.M. Roop \\ A.R. Wusterbarth
}

June 1985

Prepared for

the U.S. Department of Energy

under Contract DE-ACO6-76RLO 1830

Pacific Northwest Laboratory

Richland, Washington 99352

(a) Energy and Environmental Analysis, Inc. Arlington, Virginia 22209 



\section{PREFACE}

This appendix contains the detailed documentation correspnding to the enduse sectoral analyses presented in our main report, A Retrospective Analysis of Energy Use and Conservation Trends: 1972-1982, PNL-5026, Pacific Northwest Laboratory, Richland, Washington, July 1984. The data and methods used to calculate alternative scenarios for estimating energy savings in four economic sectors are provided in this volume. Appendix A contains the detailed documentation for the residential sector analysis. The methodology used to prepare estimates of building energy savings in the commercial sector is provided in Appendix B. Finally, Appendixes $C$ and $D$ discuss the data and explain the analytical techniques used to derive estimates of energy savings in the industrial and transportation sectors, respectively. 
$-$

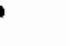

.

$\checkmark$ 
PREFACE

APPENDIX A - DETAILED DOCUMENTATION: RESIDENTIAL SECTOR ANALYSIS

i i i

A. 1

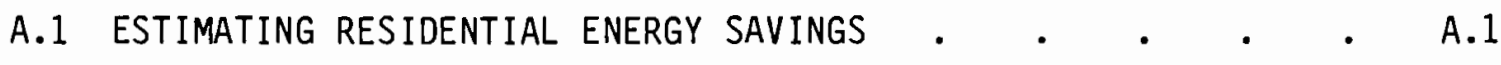
A.1.1 Line $A$.
A.1.2 Line $B$.
A.1.3 Line $C$
A.1.4 Line D
A.1.5 Line $E$.

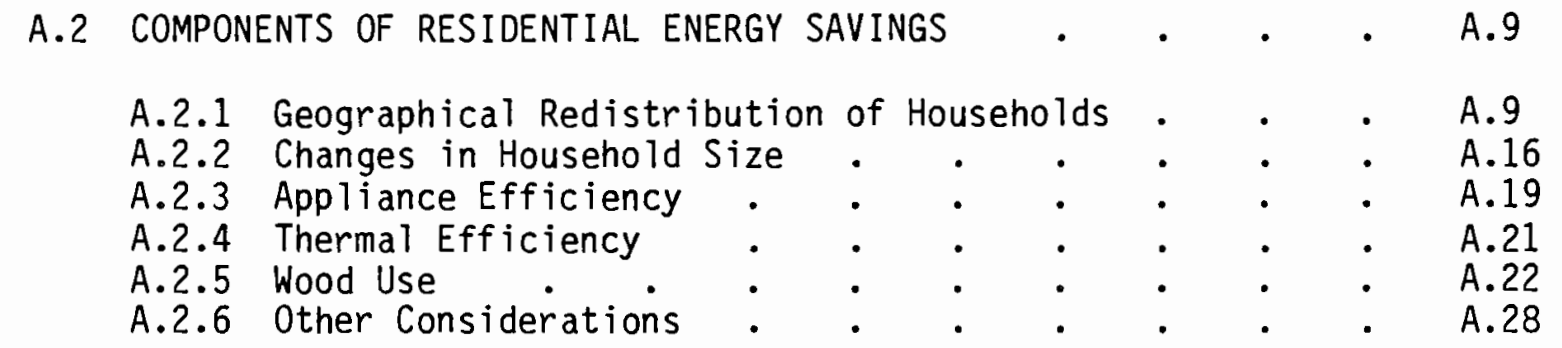

A. 1

A. 4

A. 7

A. 7

A. 8

APPENDIX B - COMMERCIAL ENERGY SAVINGS ESTIMATES: DETAILED METHODOLOGY B.1

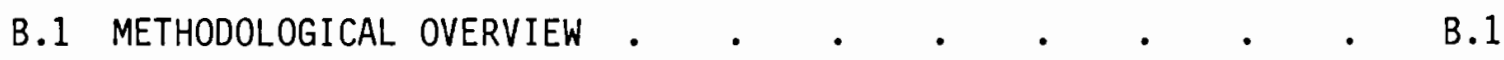

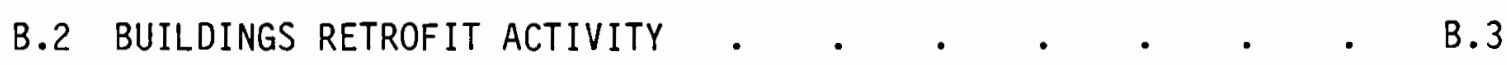

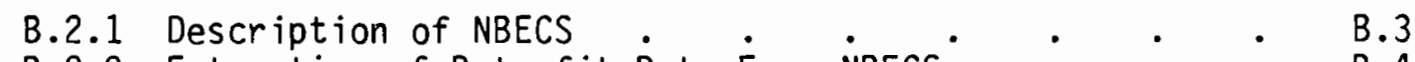

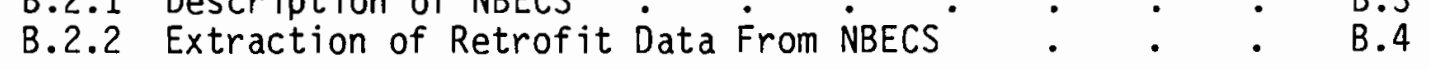

B.3 ENERGY SAVINGS IN PROTOTYPICAL BUILDINGS $\quad . \quad$. $\quad$ • $\quad$. $\quad$. 6

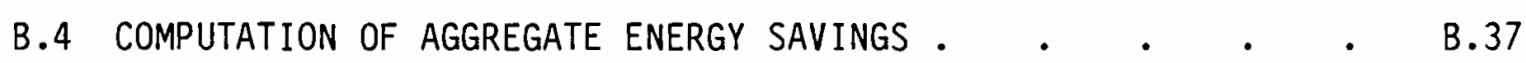

APPENDIX C - THE INDUSTRIAL SECTOR: DATA AND STATISTICAL ESTIMATES - $\quad$ C.1

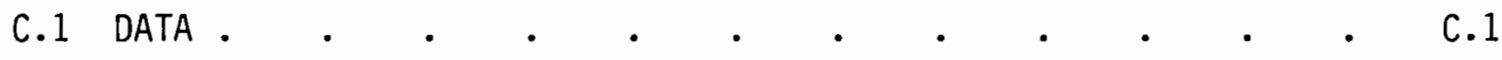

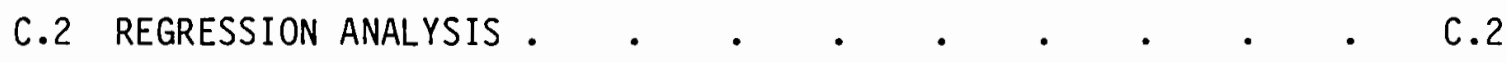

APPENDIX D - DETAILED DOCUMENTATION: TRANSPORTATION SECTOR ANALYSIS • D.1

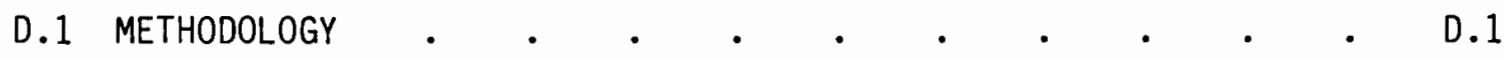

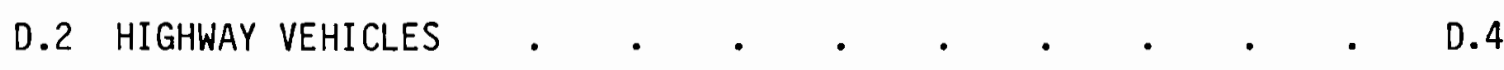

D.2.1 Automobiles. . . . . . . . . . . . D.4

D.2.2 Light-Duty Trucks . . . . . . . . . . . $\quad$. 0.20

D.2.3 Commercial Trucks . . . . . . . . . . $\quad$. 0.30 


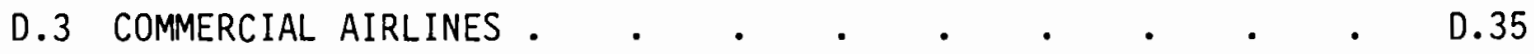

D.3.1 Introduction . . . . . . . . . . . . D.35

D.3.2 Overall Trends in Commercial Airline Fuel Consumption D. 35

D.3.3 Components of Fuel Efficiency Improvement in

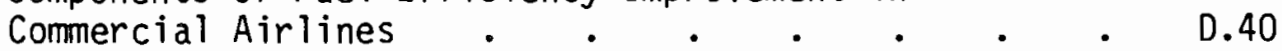

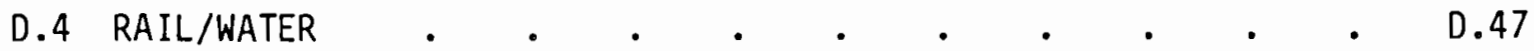

D.4.1 Rail . . . . . . . . . . . . . 0.47

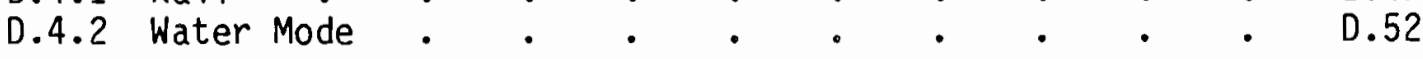

D.5 REFERENCES . . . . . . . . . . . . . D. . . D6

APPENDIX E - GENERAL METHODOLOGY FOR MEASURING ENRGY SAVINGS • • E.1

E.1 ALgebraic DEFINITIONS OF ENERGY SAVINGS . . • . . . E.1

E.1.1 Energy Savings Due to Changes in Economic Activity . E.2

E.1.2 Energy Savings Due to Energy Efficiency Improvements

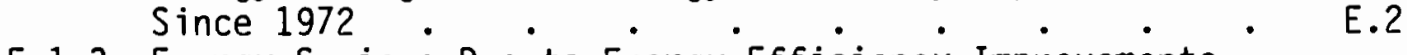

E.1.3 Energy Savings Due to Energy Efficiency Improvements
Relative to Trends . E.5

E.2 COMPUTING HISTORICAL GROWTH RATES OF EUIS AND ACTIVITIES - E.5

E.3 DERIVING TRENDED VALUES OF EUIS AND ECONOMIC ACTIVITIES . E.6

E.4 ECONOMY-WIDE AGGREGATIONS . . . . . . . . . E.6

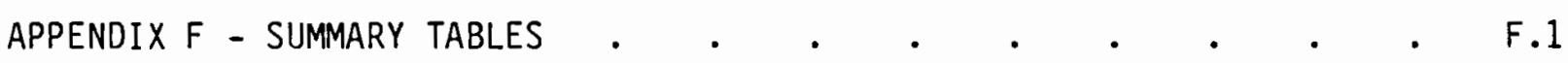




\section{FIGURES}

A.1 Alternative Estimates of Total Energy Use in the U.S., Residential Sector

A.2 Decomposing Estimated Energy Savings Due to Changes in Energy Use Intensity Since 1972, Residential Sector $\quad . \quad$ • $\quad$ • . . A.10

C.1 Decomposing Estimated Energy Savings Due to Changes in Energy Use Intensity Since 1972, Industrial Sector . $. \quad . \quad . \quad$. $\quad$ C.5

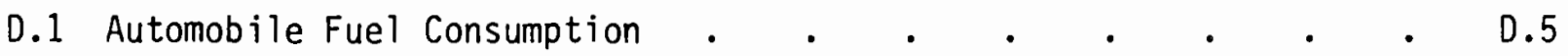

D.2 Components of the Reduction in Automobile Fuel Consumption . . D.19

D.3 Light Duty Truck Fuel Consumption . • • • • • • • • 0.21

D.4 Components of Fuel Savings in the Light Duty Truck Sector . • D.29

D.5 Commercial Truck Fuel Consumption . . . . . . . . . . . D.31

D.6 Fuel Use, Activity and Efficiency in Commercial Trucking . • D.33

D.7 Fuel Use in the U.S. Commercial Airlines Industry . . . . D.38

\begin{tabular}{l} 
D.8 Components of Fuel Efficiency Improvements in the U.S. Commercial \\
Airline Industry... \\
\hline
\end{tabular}

D.9 Fuel Consumption in the Railroad Sector . . . . . . . . . D.48

D.10 Fuel Consumption by the Water Mode . . . . . . . . . D.54

E.1 Energy Savings Measured with Lines A Through E . . • . E.4

\section{TABLES}

A.1 Actual Number of Households, Residential Energy Use, and Energy Use per Household, 1960-1982 . . . . . . . . . . A.3

A.2 Values for Lines A Through E, 1972-1982 . . . . . . . A.5

A.3 Actual and Estimated Values for Households and Energy Use per
Household, 1972 to 1982 .. . . . . . . . . . 6

A.4 Components of Total Residential Energy Savings Due to Efficiency Improvements Relative to 1972 . $\quad$ • . . . . .

A.5 Residential Energy Savings Due to Geographical Redistribution of Households 
A.6 Regression Coefficient Estimates for Equation A5 . . . . . A.15

A.7 Regression Coefficient Estimates for Equation A7 . . . . . . A.17

A.8 Calculation of Energy Savings Due to Changes in Household Size - A.18

A.9 Calculation of Energy Savings Due to Improvements in Appliance

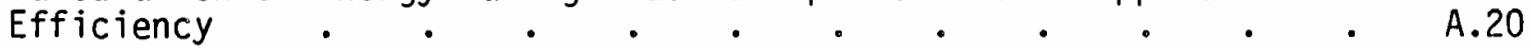

A.10 Calculation of Energy Use Reductions Due to Thermal Efficiency

Improvements $\quad . \quad+\quad \cdot \quad \cdot \quad \cdot \quad \cdot \quad \cdot \quad \cdot \quad \cdot \quad$ A.23

A.11 Calculation of Residential Energy Savings Due to Increased Wood

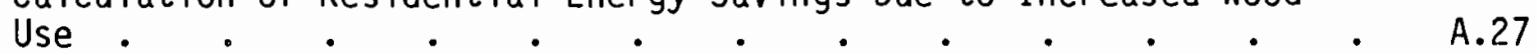

B.1 Natural Gas and Electricity Consumption, and Expenditures for

Commercial Buildings that Use Natural Gas or Electricity or Both:

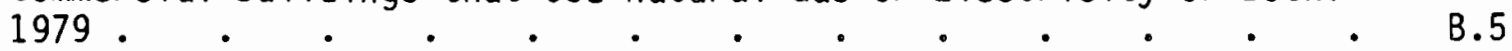

B.2 Building Categories Used in Commercial Analysis . $\quad$ • $\quad$ • $\quad$ B $\quad$ B.7

B.3 Historical Retrofit Activity, Caulking and Weatherstripping, in Assembly Buildings . . . . . . . . . B.8

B.4 Historical Retrofit Activity, Insulation, in Assembly Buildings . B.9

B.5 Historical Retrofit Activity, Window Replacement, in Assembly

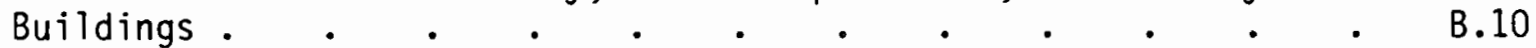

B.6 Historical Retrofit Activity, Caulking and Weatherstripping, in

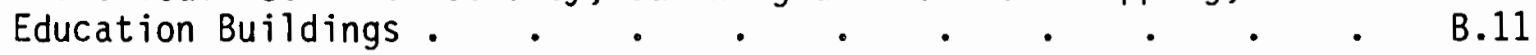

B.7 Historical Retrofit Activity, Insulation, in Education Buildings . B.12

B.8 Historical Retrofit Activity, Window Replacement, in Education

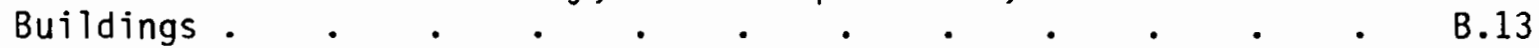

B.9 Historical Retrofit Activity, Caulking and Weatherstripping, in Small Food Sales Buildings . . . . . . . . . B.14

B.10 Historical Retrofit Activity, Insulation, in Small Food Sales

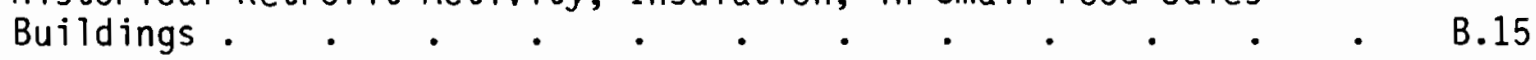

B.11 Historical Retrofit Activity, Window Replacement, in Small Food Sales Buildings

B.12 Historical Retrofit Activity, Caulking and Weatherstripping, in Large Food Sales Buildings

B.13 Historical Retrofit Activity, Insulation, in Large Food Sales Buildings. 
B.14 Historical Retrofit Activity, Window Replacement, in Large Food Sales Buildings

B.15 Historical Retrofit Activity, Caulking and Weatherstripping, in Small Office Buildings

B.16 Historical Retrofit Activity, Insulation, in Small office Buildings .

B.17 Historical Retrofit Activity, Window Replacement, in Small office Buildings .

B.18 Historical Retrofit Activity, Caulking and Weatherstripping, in Large Office Buildings

B.19 Historical Retrofit Activity, Insulation in Large Office Buildings

B.20 Historical Retrofit Activity, Window Replacement, in Assembly Buildings.

B.21 Historical Retrofit Activity, Caulking and Weatherstripping, in Small Retail/Service Buildings

B.22 Historical Retrofit Activity, Insulation in Small Retail/Service Buildings.

B.23 Historical Retrofit Activity, Window Replacement, in Small Retail/ Service Buildings

B.24 Historical Retrofit Activity, Caulking and Weatherstripping, in Large Retail/Service Buildings

B.25 Historical Retrofit Activity, Insulation, in Large Retail/Service Buildings.

B.26 Historical Retrofit Activity Window Replacement, in Large Retail/ Service Buildings

B.27 Specifications for Prototype Buildings . . . • . . B.32

B.28 Cities Used for Weather Zone Sensitivity Anatysis . . . . B.35

B.29 Simulated Energy Reductions for Retrofit Measures: Assembly

B.30 Simulated Energy Reductions for Retrofit Measures: School • . B.39

B.31 Simulated Energy Reductions for Retrofit Measures: Small Grocery Building

B.32 Simulated Energy Reductions for Retrofit Measures: Supermarket . 
B.33 Simulated Energy Reductions for Retrofit Measures: Small Office Building . $. \quad . \quad . \quad . \quad . \quad . \quad . \quad . \quad . \quad$.

B.34 Simulated Energy Reductions for Retrofit Measures: Large Office Building

B.35 Simulated Energy Reductions for Retrofit Measures: Smal1 Retail Building.

B.36 Simulated Energy Reductions for Retrofit Measures: Large Retail Building.

C.1 Data Used in the Analys is

D.1a Energy, Activity and Efficiency in Transportation.

D.1b Total Transportation Energy Use and Activity 1972-1982 • • • D.3

D.2 Actual Transportation Energy Use and Alternative Base Cases . . D.4

D.3 Actual Automobile Fuel Use and Alternative Base Cases . • • D.6

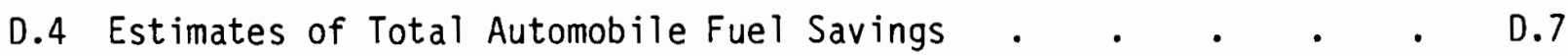

0.5 Actual Passenger Car Fuel Demand . . . . . . . . . . 0.8

D.6 Automobile Production by Percent of EPA Size Class and Corresponding Fuel Economy, Model Years 1972-1982 . . • . D.10

0.7 Impact of Size Class Shifts on New Car Fuel Economy and Fleet Fuel Consumption

D.8 Impact of New Passenger Car Technology on Fuel Consumption . - D.13

D.9 Components of Total Net Fuel Savings in the Automobile Sector $\quad$ D.14

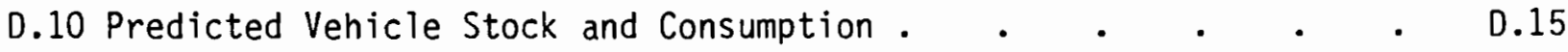

D.11 Predicted Vehicle Miles Travelled and Consumption . • • • . 0.16

D.12 Components of the Reduction in Automobile Fuel Use . . . $\quad$ D.18

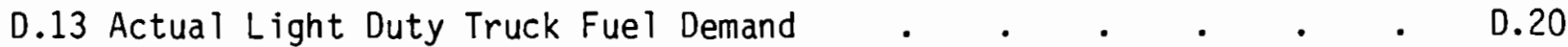

D.14 Actual Light Duty Truck Fuel Use and Alternative Base Cases . . 0.22

D.15 Estimates of Total Light Duty Truck Fuel Savings . . • • • $\quad$ 0.23

D.16 Analysis of Light Truck Market Size Mix Shift 1975-1982 • • D.25

D.17 Components of Total Net Fuel Savings in the Light Truck Sector • D.26 
D.18 Components of the Reduction in LDT Fuel Use . . . . . D.27

D.19 Actual Commercial Truck Fuel Use and Alternative Base Cases . . D.32

D.20 Alternative Estimates of Commercial Truck Fuel Savings . . . D.34

D.21 Actual U.S. Commercial Airline Fuel Use and Alternative Base Cases D.36

D.22 Actual and Trended Fuel Efficiency and Activity in the U.S.

Commercial Aircraft Sector . . . . . . . . 0.37

D.23 Alternative Estimates of Fuel Savings in the U.S. Commercial

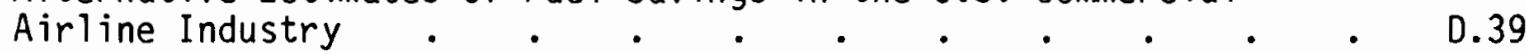

D.24 Components of Fuel Efficiency Improvement in the U.S. Commercial

Airline Industry . $. . . \quad . \quad . \quad . \quad . \quad 0.42$

D.25 Summary Statistics for Commercial Aircraft . . . . . 0.43

D.26 Actual Railroad Fuel Use and Alternative Base Cases . . . D.49

D.27 Railroad Fuel Efficiency and Activity Levels . . . . . D.50

D.28 Alternative Estimates of Railroad Fuel Savings . . . . 0.51

D.29 Summary Statistics for Domestic Waterborne Commerce . . . D.53

D.30 Actual Fuel Use and Alternative Base Cases for the Water Mode . D.55

D.31 Alternative Estimates of Fuel Savings for the Water Mode . . D.56

E.1 Concepts of "Energy Savings" . . . . . . . . E.3

F.1 Estimated Energy Savings Due to Changes in Economic Activity:
1972-1982. . . . F.1

F.2 Estimated Energy Savings Due to Efficiency Improvements Relative to 1972 Stock: 1972-1982 . . . . . . . . F.2

F.3 Estimated Energy Savings Due to Efficiency Improvements Relative to 1960-1972 Trends: 1972-1982 . . . . . . . F.3

F.4 Alternative Estimates of Total Energy Use In the Total U.S. Economy, GNP Approach, 1978-1982 . . . . . . . F.4

F.5 Alternative Estimates of Total Energy Use: Sum of Four Sectors, 1972-1982 . . . • . . . . . . . . F.5

F.6 Ratio of Alternative Estimates for Total Energy Use in the U.S. Economy: Sum-of-Four-Sector Approach versus Real Gross National Product Approach 

APPENDIX $A$

DETAILED DOCUMENTATION: RESIDENTIAL SECTOR ANALYSIS 



\section{APPENDIX A}

\section{DETAILED DOCUMENTATION: RESIDENTIAL SECTOR ANALYSIS}

This appendix contains the detailed documentation corresponding to the residential sector analysis found in Chapter 2.0 of the main report. The methods used to calculate the alternative scenarios for estimating energy savings are discussed first. Afterwards, a discussion of the methods and data used to explain residential energy savings is presented.

\section{A.1 ESTIMATING RESIDENTIAL ENERGY SAVINGS}

Total residential energy use can be expressed as the product of the number of households and the average energy use per household. The decline in total residential energy use that began in the last decade implies that energy savings have taken place through decreases in either or both of these factors. Since the available data on residential energy use include any energy savings that took place, it is necessary to estimate what energy use might have been without energy savings in order to estimate how much energy was saved. The difference between energy use without reductions and energy use with reductions is, of course, energy savings.

Four alternative scenarios were developed to simulate total residential energy consumption under various conditions. These four scenarios plus actual residential energy use are graphed in Figure A.1 for the 1972-1982 study period. All five lines are based on data from the State Energy Data System (energy use) and the Bureau of the Census in Statistical Abstract of the United States (households). Table A.1 shows the actual number of households, energy use, and energy use per household for 1960 to 1982, taken from these two data sources and used to estimate Lines $A$ through $E$. The steps used to calculate each line are discussed below.

\section{A.1.1 Line A}

Line $A$ of Figure A.1 represents the actual residential energy consumption that took place between 1972 and 1982, including any energy savings that took 


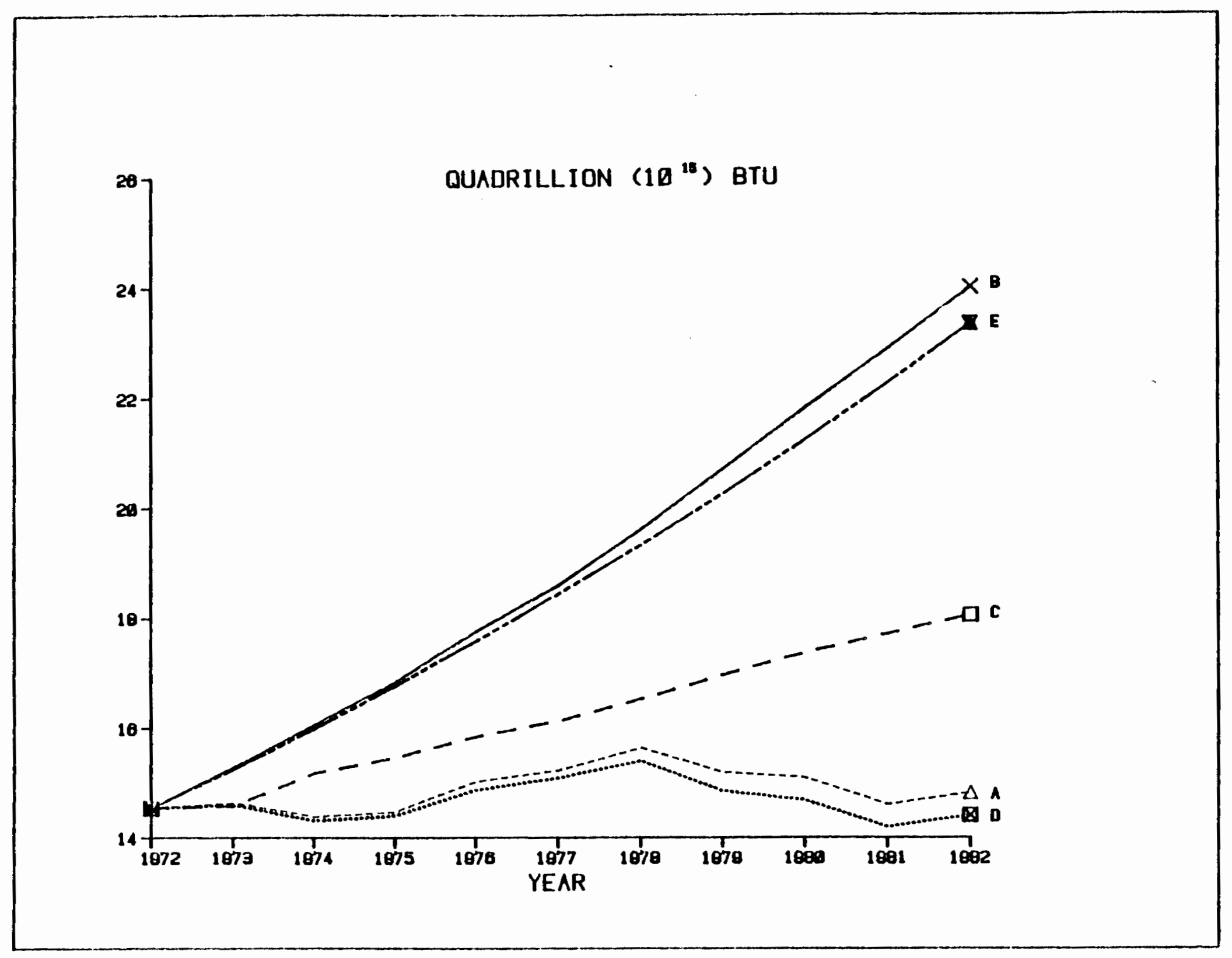

FIGURE A.1. Alternative Estimates of Total Energy Use in the U.S., Residential Sector 
TABLE A.1. Actual Number of Households, Residential Energy Use, and Energy Use per Household, 1960-1982

\begin{tabular}{|c|c|c|c|}
\hline Year & $\begin{array}{l}\text { (1) } \\
\text { Residential (a) } \\
\text { Energy Use } \\
\text { (Quads) }\end{array}$ & $\begin{array}{l}(2) \\
\text { Number of }(b) \\
\text { Households } \\
(000)\end{array}$ & $\begin{array}{l}\text { (3) } \\
\text { Energy Use }(c) \\
\text { per Household } \\
\text { (million Btu) }\end{array}$ \\
\hline $\begin{array}{l}1960 \\
1961 \\
1962 \\
1963 \\
1964\end{array}$ & $\begin{array}{l}8.312 \\
8.606 \\
9.127 \\
9.397 \\
9.714\end{array}$ & $\begin{array}{l}53,021.0 \\
53,689.0 \\
54,880.9 \\
55,418.6 \\
56,227.7\end{array}$ & $\begin{array}{l}156.762 \\
160.301 \\
166.298 \\
169.559 \\
172.821\end{array}$ \\
\hline $\begin{array}{l}1965 \\
1966 \\
1967 \\
1968 \\
1969\end{array}$ & $\begin{array}{l}10.147 \\
10.689 \\
11.171 \\
11.890 \\
12.744\end{array}$ & $\begin{array}{l}57,300.0 \\
58,332.0 \\
58,845.8 \\
60,726.0 \\
61,805.8\end{array}$ & $\begin{array}{l}177.086 \\
183.244 \\
189.835 \\
195.789 \\
206.194\end{array}$ \\
\hline $\begin{array}{l}1970 \\
1971 \\
1972 \\
1973 \\
1974\end{array}$ & $\begin{array}{l}13.366 \\
13.898 \\
14.540 \\
14.637 \\
14.381\end{array}$ & $\begin{array}{l}63,450.0 \\
64,966.8 \\
67,293.5 \\
68,737.0 \\
70,236.0\end{array}$ & $\begin{array}{l}210.654 \\
213.925 \\
216.068 \\
212.942 \\
204.753\end{array}$ \\
\hline $\begin{array}{l}1975 \\
1976 \\
1977 \\
1978 \\
1979\end{array}$ & $\begin{array}{l}14.466 \\
15.013 \\
15.218 \\
15.629 \\
15.186\end{array}$ & $\begin{array}{l}71,535.0 \\
73,297.0 \\
74,601.0 \\
76,473.0 \\
78,515.7\end{array}$ & $\begin{array}{l}202.223 \\
204.824 \\
203.992 \\
204.373 \\
193.414\end{array}$ \\
\hline $\begin{array}{l}1980 \\
1981 \\
1982\end{array}$ & $\begin{array}{l}15.084 \\
14.598 \\
14.812\end{array}$ & $\begin{array}{l}80,390.0 \\
81,968.9 \\
83,527.0\end{array}$ & $\begin{array}{l}187.635 \\
178.092 \\
177.332\end{array}$ \\
\hline
\end{tabular}
(a) SEDS.
(b) Bureau of the Census, Statistical Abstract of the United States.
(c) Column 1 divided by Column 2 . 
place. Values graphed for Line $A$ are given in Table A.2 and are equal to those in Column 1 (or Column 2 multiplied by Column 3) in Table A.1. The 1982 figure for energy use was not available from SEDS; this number was estimated by calculating the residential sector's share of combined residential and commercial energy use from SEDS for 1981 and applying the resulting proportion to the combined residential/commercial energy consumption for 1982 found in the May 1983 issue of Monthly Energy Review. Different measures of energy savings result from comparisons of Line $A$ to each of the other four lines.

\section{A.1.2 Line B}

Line $B$ represents total residential energy use assuming the actual number of households multiplied by trended energy use per household (Table A.3, Columns 1 and 4 ). Trended energy use per household was estimated using the average rate of change in energy use per household for 1960 to 1972 . When the equation:

$$
\log \text { ENERHLD }=a+b(\text { TIME) }
$$

was regressed, the average rate of change of ENERHLD (energy use per household)

was equal to $e^{b}$. The value of $e^{b}$ was found equal to 0.02868 , with $a$ standard error of 0.000885 . The rate of change (0.029) was added to one and multiplied by the energy use per household for the previous year to estimate the trended values for 1973 through 1982. In equation form the procedure looked like this:

$$
\begin{aligned}
& \text { ENERHLD }_{1972} \text { * } 1.029=\text { ENERHLD }_{1973} \\
& \text { ENERHLD }_{1973} \text { * } 1.029=\text { ENERHLD }_{1974} \\
& \text { ENERHLD }_{1981} \text { * } 1.029=\text { ENERHLD }_{1982}
\end{aligned}
$$


TABLE A.2. Values for Lines A Through E, 1972-1982 (Quadrillion Btus)

\begin{tabular}{|c|c|c|c|c|c|}
\hline Year. & Line $A$ & Line $B$ & Line $C$ & Line D & Line $\mathrm{E}$ \\
\hline 1972 & 14.540 & 14.540 & 14.540 & 14.540 & 14.540 \\
\hline 1973 & 14.637 & 15.283 & 14.582 & 14.602 & 15.246 \\
\hline 1974 & 14.381 & 16.069 & 15.176 & 14.307 & 15.986 \\
\hline 1975 & 14.466 & 16.840 & 15.456 & 14.400 & 16.762 \\
\hline 1976 & 15.013 & 17.756 & 15.837 & 14.861 & 17.576 \\
\hline 1977 & 15.218 & 18.596 & 16.119 & 15.082 & 18.429 \\
\hline 1978 & 15.629 & 19.615 & 16.523 & 15.397 & 19.324 \\
\hline 1979 & 15.186 & 20.723 & 16.965 & 14.848 & 20.262 \\
\hline 1980 & 15.084 & 21.833 & 17.370 & 14.678 & 21.246 \\
\hline 1981 & 14.598 & 22.908 & 17.711 & 14.197 & 22.278 \\
\hline 1982 & 14.812 & 24.020 & 18.048 & 14.405 & 23.359 \\
\hline
\end{tabular}

Source: Pacific Northwest Laboratory 
TABLE A.3. Actual and Estimated Values for Households and Energy Use per Household, 1972 to 1982

\begin{tabular}{|c|c|c|c|c|c|}
\hline Year & $\begin{array}{c}\text { (1) } \\
\text { Actual } \\
\text { Number of } \\
\text { Households }(a) \\
(000) \\
\end{array}$ & $\begin{array}{c}\text { (2) } \\
\text { Trended } \\
\text { Number of } \\
\text { Households }(b) \\
(000) \\
\end{array}$ & $\begin{array}{c}\text { (3) } \\
\text { Actual } \\
\text { Energy Use } \\
\text { per Household (c) } \\
\text { (million Btu) } \\
\end{array}$ & $\begin{array}{c}\text { (4) } \\
\text { Trended } \\
\text { Energy Use } \\
\text { per Household (b) } \\
\text { (million Btu) } \\
\end{array}$ & $\begin{array}{c}(5) \\
1972 \\
\text { Energy Use } \\
\text { per Household (b) } \\
\text { (million Btu) } \\
\end{array}$ \\
\hline 1972 & $67,293.5$ & $67,293.5$ & 216.068 & 216.068 & 216.068 \\
\hline 1973 & $68,737.0$ & $68,572.1$ & 212.942 & 222.334 & 216.068 \\
\hline 1974 & $70,236.0$ & $69,874.9$ & 204.753 & 228.782 & 216.068 \\
\hline 1975 & $71,535.0$ & $71,202.6$ & 202.223 & 235.416 & 216.068 \\
\hline 1976 & $73,297.0$ & $72,555.4$ & 204.824 & 242.243 & 216.068 \\
\hline 1977 & $74,601.0$ & $73,934.0$ & 203.992 & 249.268 & 216.068 \\
\hline 1978 & $76,473.0$ & $75,338.7$ & 204.373 & 256.497 & 216.068 \\
\hline 1979 & $78,515.7$ & $76,770.2$ & 193.414 & 263.936 & 216.068 \\
\hline 1980 & $80,390.0$ & $78,228.8$ & 187.635 & 271.590 & 216.068 \\
\hline 1981 & $81,968.9$ & $79,715.1$ & 178.092 & 279.466 & 216.068 \\
\hline 1982 & $83,527.0$ & $81,229.7$ & 177.332 & 287.570 & 216.068 \\
\hline
\end{tabular}

\footnotetext{
(a) Bureau of the Census, Statistical Abstract

(b) Pacific Northwest Laboratory

(c) SEDS
} 
Where: $\quad$ ENERHLD $t=$ actual energy use per household for year $t$ ENERHLD $t=$ trended energy use per household for year $t$

The actual values for ENERHL $D_{t}$ derived and graphed in Figure $A .1$ are given in Table A.2.

The difference between $L$ ine $B$ and Line $A$ results in the largest measure of energy savings. Since both lines use actual households as a factor, the difference between the two results is the difference between trended and actual energy use per household. Since the trended estimate is based on the rapidly rising average increases in energy use per household between 1960 and 1972, its continued increase does not account for the effects of the dramatic increase in some fuel prices that accompanied the Arab oil embargo of 1973-1974 and appear to have motivated households to save energy.

\section{A.1.3 Line C}

Line $C$ was calculated by multiplying the actual number of households for each year by the 1972 level of energy use per household (Table A.3, Columns 1 and 5). Like Line $B$, Line $C$ shares with Line $A$ the common factor of actual households but has a different measure of energy use per household. As seen in Figure $A .1$, Line $C$ is a more conservative measure of total residential energy use than Line $B$ because it does incorporate a change in energy use per household. It was the difference between Line $C$ and Line $A$ that was used as the measure of energy savings in the second phase of the residential sector analysis.

\section{A.1.4 Line D}

Residential energy use graphed as Line $D$ was based on the actual level of energy use per household (as in Line A) and a trended estimate of the number of households (Table A.3, columns 2 and 3 ). The computation of trended households is analogous to that for the trended energy use per household calculated for Line B: 


$$
\begin{aligned}
& H L D_{1972} \text { * } 1.019=\hat{H L D_{1973}} \\
& \hat{H L D_{1973}} \text { * } 1.019=\hat{H L D_{1974}}
\end{aligned}
$$

Where: $\quad H L D_{t}=$ actual number of households for year $t$

$H L D_{t}=$ estimated (trended) number of households for year $t$

$1.019=$ factor that adjusts the number of households according to the historical rate of change of the number of households from 1960 to 1972

Line $O$ differs from Line $B$ and $L$ ine $C$ by both the household factor and the energy use per household and differs from Line $A$ by only the household factor. Line D lies below Line A (Figure A.1), because trended households were less than actual households. This implies that more total energy, rather than less, was consumed in the residential sector because of changes in the number of households. In other words, no energy savings can be attributed to changes in the number of households because households grew at a faster rate from 1972 to 1982 than they had between 1960 and 1972 .

\section{A.1.5 Line $E$}

Line $E$ differs from Line $A$ by both the household and energy use factors. Line $E$ is calculated by multiplying trended households by trended energy use per household (Table A.3, Columns 2 and 4 ). Line $E$ shares a relationship with Line $B$ that is similar to the relationship between Lines $A$ and $D$ just discussed. Because Line $E$ is based on estimated households and lies below Line $B$, it can be assumed that more, rather than less, energy was consumed because of the change in the number of households. Because it uses trended energy use per household, Line $E$ is considerably larger than Line $A$ (see discussion for Line B). 


\section{A.2 COMPONENTS OF RESIDENTIAL ENERGY SAVINGS}

The next step in the residential-sector analysis was to attempt to explain the factors contributing to the conservation of energy for the study period. Graphically this task involved estimating the lines that fall between Line $C$ and Line $A$, as shown in Figure A.2. The areas between the lines represent the energy savings attributable to each of six components: geographical redistribution of households (migration), changes in household size, improved appliance efficiency, improved building thermal efficiency, increase in wood use, and a residual category, which includes changes in public attitudes toward energy conservation and any unidentified factors. The data which support these trends are shown in Table A.4. Changes in dwelling unit size were determined to be insignificant in the King et al. (1982) study, so that category will be omitted from this report. The remainder of this appendix contains the documentation for estimating the five lines shown in Figure A.2.

\section{A.2.1 Geographical Redistribution of Households}

The migration of households from the colder states of the Northeast and Midwest to the warmer Sun Belt states over the past decade has contributed to the reduction in residential energy consumption. In order to measure the impact of migration on energy use, it was necessary to compare energy use both with and without the effects of migration. Actual energy use already includes the effects of migration, so it was only necessary to construct a scenario of what energy use would have been without migration. The scenario developed involved holding state proportions of total U.S.households constant throughout the study period at the 1972 levels.

Since the effects of geographical redistribution of households occur at the state level, national energy use for both the actual and base-case scenarios needed to be defined in state-level terms. For the case of actual energy use, national energy use per state was defined as the sum of the products of each state's proportion of total U.S. households and energy use per household for a given year:

$$
E_{t}=\sum_{r=1}^{51} P_{r t} E_{r t}
$$




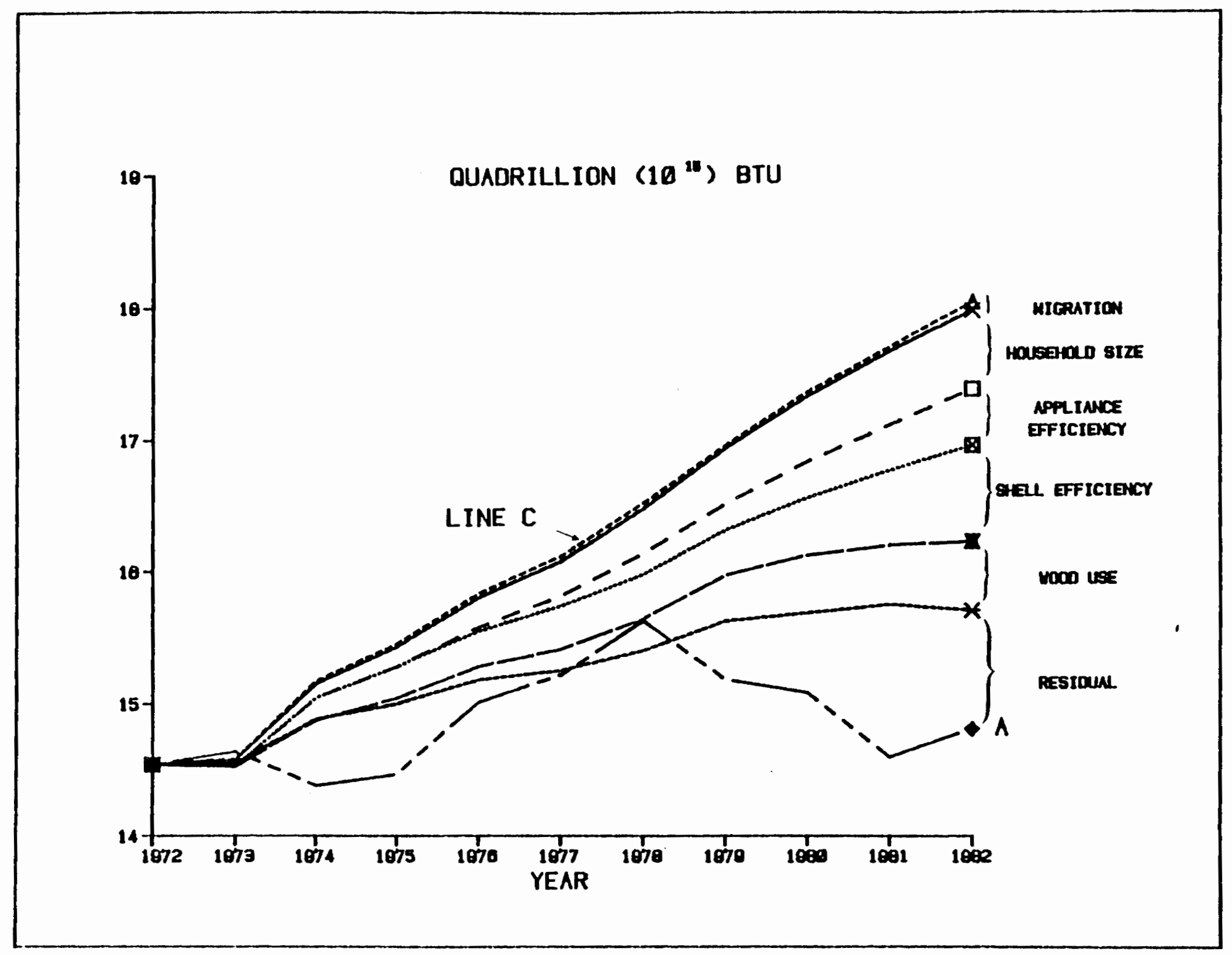

FIGURE A.2. Decomposing Estimated Energy Savings Due to Changes in Energy Use Intensity Since 1972, Residential Sector 
TABLE A.4. Components of Total Residential Energy Savings Due to Efficiency Improvements Relative to 1972

(Quadrillion Btu)

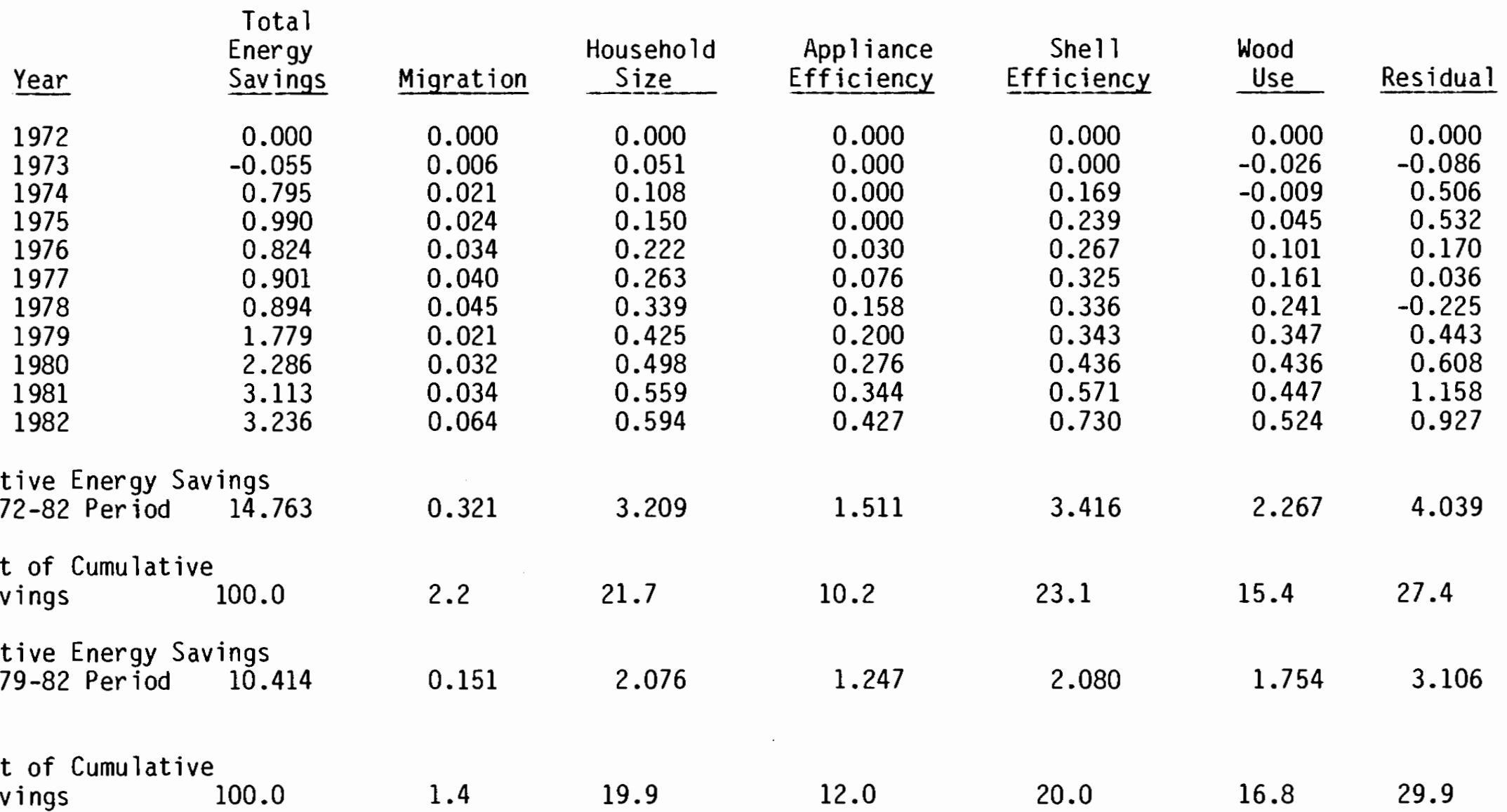


Where: $E_{t}=$ national energy use per household for year $t$ $P_{r t}=$ proportion of U.S. households in state $r$ in year. $t$ $E_{r t}=$ energy use per household for state $r$ in year $t$

This measure of national energy use per household includes the effects of population shifts because the state proportions of U.S. households were allowed to vary by year.

To calculate the base case scenario that excludes the effects of migration, it was assumed that each state's proportion of U.S. households remained at its respective 1972 value throughout the study period. In equation form, the base case energy use per household is:

$$
\hat{E}_{t}=\sum_{r=1}^{51} P_{r 72} E_{r t}
$$

$$
\text { Where: } \begin{aligned}
& \hat{E}_{\mathrm{t}}=\text { national energy use per household for the base-case } \\
& \text { scenario in year } t
\end{aligned}
$$

National savings in energy use per household are equal to the difference $\hat{E}_{t}-E_{t}$. Total residential sector energy savings are equal to that difference multiplied by the corresponding number of U.S. households for each year in the study period. The final results are shown in Table A.5.

In order to use Equations $A 2$ and $A 3$, data on state proportions of U.S. households and state energy use per household were needed for 1972 through 1982. State-level proportions for 1960 through 1980 were calculated from the data available from the Bureau of the Census, as shown in Equation A4:

$$
\text { PHLD } r t=\frac{H L D_{r t}}{H L D_{U S t}}
$$


TABLE A.5. Residential Energy Savings Due to Geographical Redistribution of Households

\section{(Quads)}

$\begin{array}{llll}\frac{\hat{E}_{t}}{1} & \frac{E_{t}}{14.540} & \text { Savings } \\ 1972 & \frac{14.540}{14.637} & 14.637 & 0 \\ 1973 & 14.402 & 14.381 & 0.006 \\ 1974 & 14.490 & 14.466 & 0.021 \\ 1975 & 15.047 & 15.013 & 0.024 \\ 1976 & 15.258 & 15.218 & 0.034 \\ 1977 & 15.674 & 15.629 & 0.040 \\ 1978 & 15.207 & 15.186 & 0.045 \\ 1979 & 15.116 & 15.084 & 0.021 \\ 1980 & 14.632 & 14.598 & 0.032 \\ 1981 & 14.876 & 14.812 & 0.034 \\ 1982 & & & 0.064\end{array}$

Source: Pacific Northwest Laboratory 
Where: $\quad$ PHLD $_{r t}=$ proportion of U.S. households in state $r$ in year $t$ $\mathrm{HLD}_{r \mathrm{t}}=$ number of households in state $r$ in year $\mathrm{t}$ HLD ${ }_{\text {USt }}=$ number of households in the U.S. in year $t$

Only national values for the number of households were available for 1981 and 1982. To estimate state-level proportions for those two years, the following regression was run:

$$
\log \text { PHLD }_{r t}=a+b\left(\text { TIME }_{t}\right)+c(\text { DUM1980 })_{t}
$$

Where: $\quad \operatorname{TIME}_{t}=$ year $t$, where $t$ is equal to 1960-1980

$$
\begin{aligned}
\text { DUM1980 }= & \text { dummy variable for state } r \text { in year } t \text {, where DUM1980 }=1 \\
& \text { for } t=1980 \text { and } 0 \text { otherwise }
\end{aligned}
$$

Values for the coefficients $a, b$, and $c$ are shown in Table A.6.

The other data requirement for Equations $A 2$ and $A 3$ was energy use per household by state. State-level data were available for 1960 through 1981 from SEDS, and a national figure was available for 1982. Calculations similar to those just described for state proportions of households were used to estimate energy use per household at the state level for 1982. First, each state's share of total U.S. residential-sector energy consumption was computed for the years in which data were available:

$$
\text { ENERSH }_{r t}=\frac{\text { ENER }_{r t}}{\text { ENER }_{\text {USt }}}
$$

Where: ENERSH $_{r t}=$ proportion of U.S. energy use consumed in state $r$ in year $t$

$$
\begin{aligned}
\text { ENER }_{r t} & =\text { energy use in state } r \text { in year } t \\
\text { ENER }_{\text {USt }} & =\text { energy use in the U.S. in year } t \\
t & =1960 \text { to } 1981
\end{aligned}
$$

The resulting energy proportions were run in regressions by state to estimate the proportions for 1982:

$$
\log \text { ENERSH }_{r t}=e+f\left(\text { TIME }_{t}\right)+\text { gDUM1981 } r t
$$

Where: $\quad$ DUM1981 $r t=$ dummy variable, where DUM1981 $=1$ if $t=1981$ and DUM1981 $=0$ if $t \neq 1981$ 
IABLE A.6. Regression Coefficient Estimates for Equation A5

\begin{tabular}{|c|c|c|c|c|c|c|c|}
\hline State & a & b & c & State & a & $b$ & $c$ \\
\hline$A L$ & -4.0717 & -0.0016 & 0.0290 & MT & -5.5811 & -0.0038 & 0.0195 \\
\hline AK & -6.9315 & 0.0235 & 0.02115 & NE & -4.8110 & -0.0060 & -0.0037 \\
\hline$A Z$ & -5.0121 & 0.0258 & 0.0507 & NV & -6.3133 & 0.0304 & 0.1005 \\
\hline AR & -4.6084 & 0.0004 & 0.0198 & $\mathrm{NH}$ & -5.7109 & 0.0080 & 0.0298 \\
\hline $\mathrm{CA}$ & -2.2470 & 0.0077 & -0.0334 & NJ & -3.3190 & -0.0022 & -0.0536 \\
\hline CO & -4.6431 & 0.0143 & 0.0291 & NM & -5.4038 & 0.0062 & 0.0727 \\
\hline CT & -4.2205 & -0.0006 & -0.0503 & NY & -2.1685 & -0.0109 & -0.0601 \\
\hline DE & -6.0223 & 0.0047 & -0.0347 & $N C$ & -3.7661 & 0.0048 & 0.0189 \\
\hline$D C$ & -5.2981 & -0.0171 & -0.1020 & ND & -5.7217 & -0.0083 & 0.0335 \\
\hline $\mathrm{FL}$ & -3.5538 & 0.0248 & 0.0134 & $\mathrm{OH}$ & -2.8537 & -0.0061 & -0.0130 \\
\hline GA & -3.8840 & 0.0058 & 0.0254 & OK & -4.2692 & -0.0010 & 0.0288 \\
\hline HI & -5.8779 & 0.0134 & -0.0110 & $O R$ & -4.5551 & 0.0062 & 0.0419 \\
\hline ID & -5.6393 & 0.0027 & 0.0718 & PA & -2.6904 & -0.0089 & -0.0166 \\
\hline IL & -2.7709 & -0.0074 & -0.0106 & RI & -5.3192 & -0.0066 & -0.0070 \\
\hline IN & -3.6134 & -0.0041 & -0.0065 & SC & -4.4769 & 0.0047 & 0.0332 \\
\hline IA & -4.1346 & -0.0090 & 0.0022 & SD & -5.6129 & -0.0099 & 0.0220 \\
\hline KS & -4.3455 & -0.0084 & 0.0086 & TN & -3.9507 & 0.0018 & 0.0281 \\
\hline KY & -4.1260 & -0.0018 & 0.0256 & $T X$ & -2.9076 & 0.0059 & 0.0556 \\
\hline LA & -4.0590 & -0.0006 & 0.0483 & UT & -5.3929 & 0.0066 & 0.0727 \\
\hline ME & -5.2715 & -0.0037 & 0.0387 & VT & -6.2029 & 0.0033 & 0.0227 \\
\hline MD & -4.1034 & 0.0083 & -0.0594 & VA & -3.8881 & 0.0072 & -0.0051 \\
\hline MA & -3.5200 & -0.0045 & -0.0375 & WA & -4.0960 & 0.0049 & 0.0577 \\
\hline MI & -3.1182 & -0.0022 & -0.0210 & WV & -4.6267 & -0.0082 & 0.0440 \\
\hline MN & -3.9777 & -0.0011 & 0.0007 & WI & -3.8328 & -0.0012 & -0.0069 \\
\hline MS & -4.5207 & -0.0040 & 0.0379 & WY & -6.3569 & 0.0017 & 0.1407 \\
\hline MO & -3.6312 & -0.0068 & -0.0060 & & & & \\
\hline
\end{tabular}

Source: Pacific Northwest Laboratory 
Values for the coefficients e, $f$, and $g$ are shown in Table A.7. The estimated 1982 proportion for each state was then multiplied by the national energy-use figure of 14.842 quads to get the estimated energy use per state. Division of energy use per state by the corresponding number of households per state ${ }^{1}$ yielded the energy use per household for 1972 to 1982 that was used in Equations $A 2$ and $A 3$.

\section{A.2.2 Changes in Household Size}

Between 1972 and 1982, the average number of persons per household in the U.S. fell from 3.11 to 2.78. The econometrics literature suggests that there is a significant relationship between energy use per household and the number of people residing in each household. Although changes in household size are not a factor directly impacted by policy makers, it is a factor of which they should be aware.

Table A.8 shows the steps used to calculate energy savings from changes in household size. The number of persons per household (household size) was calculated based on population and household data published in various issues of Statistical Abstract. Next, the percentage change in household size from 1972 to each of the remaining years in the study period was calculated (Column 2, Table A.8). The estimated percentage change in energy use per household (Column 3) was then calculated by multiplying the household cumulative percentage-change series by 0.3047 , the estimated weighted-average elasticity of household electricity and natural gas demand with respect to household size. $^{2}$ This elasticity was derived from the Residential Energy Consumption Survey (RECS) data set, by estimating a household electricity and natural gas demand function in which household electricity use was related to electricity

1 Note that the number of households per state for 1981 and 1982 had to be estimated by multiplying the estimated state-level shares by the national totals for 1981 and 1982 .

2

The elasticity of $Y$ with respect to $X$ represents the percentage change in $Y$ caused by a 1 percent increase in $X$. 
TABLE A.7. Regression Coefficient Estimates for Equation A7

\begin{tabular}{lrrrrrrrr} 
State & \multicolumn{1}{c}{$\mathrm{e}$} & $\mathrm{f}$ & $\mathrm{g}$ & $\mathrm{State}$ & $\mathrm{e}$ & $\mathrm{f}$ & $\mathrm{g}$ \\
AL & -4.3934 & 0.0179 & -0.0656 & $\mathrm{NT}$ & -5.5966 & 0.0017 & -0.0263 \\
AK & -6.9780 & 0.0539 & -0.2950 & NE & -4.6428 & -0.0073 & -0.0167 \\
AZ & -5.3501 & 0.0339 & -0.0407 & NV & -6.3725 & 0.0400 & -0.0610 \\
AR & -4.9010 & 0.0232 & -0.1948 & NH & -5.3446 & -0.0024 & -0.1482 \\
CA & -2.5352 & 0.0041 & -0.0381 & NJ & -3.1596 & -0.0119 & 0.0287 \\
CO & -4.5401 & 0.0067 & 0.0307 & NM & -5.3353 & -0.0106 & 0.0100 \\
CT & -4.0641 & -0.0109 & 0.0884 & NY & -2.2806 & -0.0176 & -0.0244 \\
DE & -5.8346 & -0.0030 & -0.1978 & NC & -3.7741 & 0.0046 & 0.0373 \\
DC & -5.8427 & -0.0175 & 0.0139 & ND & -5.6966 & -0.0060 & 0.1558 \\
FL & -4.2092 & 0.0478 & -0.0375 & OH & -2.5476 & -0.0132 & 0.0189 \\
GA & -4.1954 & 0.0200 & 0.0221 & OK & -4.3596 & 0.0086 & 0.0481 \\
HI & -7.3917 & 0.0511 & -0.1820 & OR & -4.5009 & 0.0071 & -0.0008 \\
ID & -5.7758 & 0.0204 & -0.0014 & PA & -2.5209 & -0.0156 & 0.0703 \\
IL & -2.6406 & -0.0039 & -0.0699 & RI & -5.1403 & -0.0169 & -0.1328 \\
IN & -3.4390 & -0.0018 & -0.0275 & SC & -4.6855 & 0.0133 & 0.0538 \\
IA & -3.9711 & -0.0105 & 0.0250 & SD & -5.5991 & -0.0068 & 0.0112 \\
KS & -4.1648 & -0.0113 & -0.0257 & TN & -3.9991 & 0.0140 & -0.0494 \\
KY & -4.3749 & 0.0133 & 0.0246 & TX & -3.1457 & 0.0189 & 0.0074 \\
LA & -4.4223 & 0.0223 & 0.0341 & UT & -5.3369 & 0.0139 & 0.0499 \\
ME & -5.0109 & -0.0091 & -0.1409 & VT & -5.7832 & -0.0037 & -0.1595 \\
MD & -4.0694 & 0.0007 & 0.0473 & VI & -3.9753 & 0.0105 & -0.0118 \\
MA & -3.1639 & -0.0204 & -0.1023 & WA & -4.0015 & 0.0089 & 0.1825 \\
MI & -2.8298 & -0.0081 & -0.0131 & WV & -4.7300 & -0.0026 & 0.1165 \\
MN & -3.7910 & -0.0045 & -0.0470 & WI & -3.5639 & -0.0079 & -0.0392 \\
MS & -4.9112 & 0.0206 & -0.1272 & WY & -6.2791 & 0.0055 & 0.0339 \\
MO & -3.7360 & 0.0030 & -0.0441 & & & &
\end{tabular}

Source: Pacific Northwest Laboratory 
TABLE A.8. Calculation of Energy Savings Due to Changes in Household Size

$\frac{1}{\infty}$
(1)

(2)

Percentage Change
in Household Size

vis-d-vis 1972

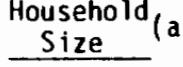

3.110

3.075

3.038

3.012

2.968

2.946

2.904

2.860

2.826

2.797

2.784

0.000

$-1.125$

$-2.315$

$-3.151$

$-4.566$

$-5.273$

$-6.624$

$-8.039$

$-9.132$

$-10.064$

$-10.482$

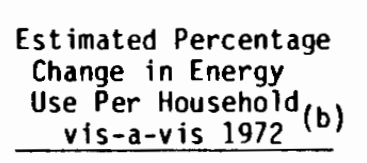

(3)

(4)

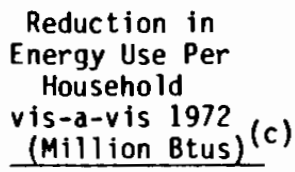

0.000

$-0.343$

$-0.705$

$-0.960$

$-1.391$

$-1.607$

$-2.018$

$-2.449$

$-2.783$

$-3.067$

$-3.194$
0.000

0.741

1.523

2.074

3.006

3.472

4.360

5.292

6.013

6.627

6.901
(5)

Reduction in U.S.

Energy Use Due to Household Size Reductions vis-a-vis, (d) 1972 (Quads)
0.000
0.509
0.107
0.148
0.220
0.259
0.333
0.416
0.483
0.543
0.576

\footnotetext{
(a) Bureau of the Census

(b) Equal to Column 2 multiplied by 0.3047 , the estimated elasticity of household energy demand with respect to household size.

(c) Column 3 (divided by 100 ) multiplied by 216.068 , the 1972 value of energy consumption per household in million Btu.

(d) Column 4 multiplied by the number of households (Table B.1).
} 
price, income, climate, number of residents and dummy variables ${ }^{3}$ representing whether or not the home had 1) space heating, 2) central air conditioning, 3) room air conditioning, and 4) various appliances, that used electricity or natural gas. Interaction effects were inserted into this equation; the effect of an increase in the number of people on electricity use was greater if the home had electric heating than if it did not. Elasticities were generated for six different categories of homes, depending upon the combination of electric space heating and air conditioning units in the home. The elasticities calculated for each category were then weighted by the percentage of homes in the RECS sample with the corresponding attributes and added to obtain the weighted-average household size elasticity for electricity of 0.3047 . It is assumed in this analysis that the energy use elasticity with respect to household size is closely approximated by this electricity use elasticity.

To compute the actual amount of energy saved per household because of decreases in household size, the figures of Column 3 were divided by 100 and multiplied by 216.068 , the 1972 value of energy consumption per household. The resulting series (Column 4 ) is multiplied by the actual number of households (Table A.1) for each of the study years to get the total U.S. savings for each year that are attributed to the decline in household size.

\section{A.2.3 Appliance Efficiency}

Improvements in the energy efficiency of appliances (including furnaces and air conditioners) contributed to residential energy savings, particularly between 1976 and 1982. The estimates of energy savings from increased appliance efficiency shown in Table A.9 are based on Lawrence Berkeley Laboratory's version of the residential energy use model created by Oak Ridge National Laboratory (ORNL). The Oak Ridge model used in this study includes seven major appliances (space heating equipment, air conditioners, water heaters, refrigerators, freezers, ranges and ovens, and clothes dryers), and three major fuels (electric, gas, and oil). The method used is the same as

\footnotetext{
3 Dummy variables have a value of 1 if the condition is true, and 0 otherwise.
} 
TABLE A.9. Calculation of Energy Savings Due to Improvements in Appliance Efficiency

(1)

(2)

\begin{tabular}{|c|c|c|}
\hline Year & $\begin{array}{l}\text { Energy Use by } \\
\text { Electric } \\
\text { Appliances (a) } \\
\text { (Quads) }\end{array}$ & $\begin{array}{c}\text { Energy Use by } \\
0 \text { il and Gas } \\
\text { Appliances (a) } \\
\text { (Quads) (a) }\end{array}$ \\
\hline 1972 & 8.300 & 6.500 \\
\hline 1973 & 8.300 & 6.500 \\
\hline 1974 & 8.300 & 6.500 \\
\hline 1975 & 8.300 & 6.500 \\
\hline 1976 & 8.278 & 6.499 \\
\hline 1977 & 8.233 & 6.492 \\
\hline 1978 & 8.176 & 6.483 \\
\hline 1979 & 8.136 & 6.471 \\
\hline 1980 & 8.080 & 6.457 \\
\hline 1981 & 8.025 & 6.432 \\
\hline 1982 & 7.970 & 6.418 \\
\hline
\end{tabular}

(3)

\begin{tabular}{|c|}
\hline $\begin{array}{l}\text { Energy Use by } \\
\text { All Appliances (b) } \\
\text { (Quads) }\end{array}$ \\
\hline 14.800 \\
\hline 14.800 \\
\hline 14.800 \\
\hline 14.800 \\
\hline 14.777 \\
\hline 14.725 \\
\hline 14.659 \\
\hline 14.607 \\
\hline 14.537 \\
\hline 14.457 \\
\hline 14.388 \\
\hline
\end{tabular}

(4)

Stock
Efficiency

Index

100.0

100.0

100.0

100.0

99.8

99.5

99.0

98.7

98.2

97.7

91.2
(5)

(6)

Estimated U.S.

Actual U.S. Energy Use Without

Residential Efficiency

Energy Use

$\underset{\text { (Quads) }}{\text { Energy Use }}$

14.540

14.637

14.381

14.466

15.013

15.218

15.629

15.186

15.084

14.598

14.812

\begin{tabular}{c}
$\begin{array}{c}\text { Improvements } \\
\text { (Quads) }\end{array}$ \\
\hline 14.540 \\
14.637 \\
14.381 \\
14.466 \\
15.043 \\
15.294 \\
15.787 \\
15.386 \\
15.360 \\
14.942 \\
15.239
\end{tabular}

(7)

Energy Savings

Due to Impravements

in Apptiance

Efficiency

(Quads) $(e)$

0.000

0.000

0.000

0.000

0.030

0.076

0.158

0.200

0.276

0.344

0.427

(a) From the ORNL. model of residential energy use

(b) Column 1 plus Column 2

(c) From Table A.1

(d) Column 5 divided by Column 4

(e) Column 6 minus Column 7 
that described in King et al,, but the inputs to the ORNL model have been updated and extended, resulting in slightly different figures than those reported in the King study. More details about the method used can be found in King et al. (1982).

Table A.9 shows the steps used to compute appliance efficiency savings once the ORNL model has generated estimates of appliance energy consumption. Columns 1 and 2 of Table A.9 contain the model's estimates of energy consumption by electric, and $0 i 1$ and gas appliances, respectively. These figures were based on the assumptions that the 1977 stock is held constant, so that efficiency improvements occur because of turnover of old stock to more energy efficient new stock. Adding Columns 1 and 2 yields an estimate of energy consumption for all appliances for each of the years in the study period (Column 3). The next step was to create an index of the efficiency of the stock (Column 4), by dividing all of the figures in Column 3 by 14,800 , the 1972 estimate of energy consumption by the stock. The index is divided into the actual U.S. residential energy consumption (Column 5) to get simulated U.S. energy consumption if no improvements in appliance efficiency had been realized in the 1972 to 1982 period (Column 6). The difference between the actual and simulated U.S. energy use is equal to the energy savings that are attributable to improvements in appliance efficiency (Column 7). Between 1976 and 1982, energy saved through the use of energy efficient appliances grew from 0.030 quads to 0.427 quads.

\section{A.2.4 Thermal Efficiency}

During the 1972 to 1982 period, substantial improvements were made to the thermal integrity or efficiency of U.S. homes. Many households installed wall and ceiling insulation, storm windows and doors, weatherstripping, and caulking in order to reduce the energy used for space heating and cooling. During both the entire study period and the 1979-1982 period, thermal efficiency improvements accounted for more residential energy savings than any of the other four factors analyzed.

The method used to calculate thermal efficiency energy savings in the residential sector is the method described in King et al. (1982), with the 
following exceptions: First, the analysis in this study was performed only at the national level, whereas king et al. looked at regional efficiency improvements and then calculated a national weighted-average thermal efficiency index. Second, the effects of thermal efficiency improvements on energy use for electric space heating, electric central air conditioning, electric room air conditioning, and non-electric space heating are analyzed separately in this report, using demand elasticities with respect to thermal efficiency estimates developed specifically for each use.

Table A.10 contains the progression of calculations used to compute thermal efficiency-related savings for each end use. The percentage increase in thermal efficiency compared to 1972 levels is calculated using a regression equation estimated using the NIECS/RECS databases aggregate U.S. data for the 1972-1982 period. The reduction in energy use is then calculated using the demand elasticity for each end use and the 1972 estimated fuel use (electricity or nonelectricity). Multiplying by the number of households using each end use gives the total savings from thermal efficiency improvements for each end use. The sum of savings for each of the four end uses is the total residential thermal efficiency savings.

\section{A.2.5 Wood Use}

The use of wood as an energy source varies among households. Some households use wood as a primary fuel, while many more use it as a secondary fuel. The analysis here assumes that increases in wood use over the level of use in 1972 were made at the expense of the fuels named in the definition of residential energy consumption: electricity, natural gas, coal, distillate, kerosene, and LPG. Energy savings due to increases in wood use were equal to the difference between actual wood use for each of the years from 1972 to 1982 and the level of use in 1972.

Data on wood use were taken from the Energy Information Administration report, Estimates of U.S. Wood Energy Consumption from 1949 to 1981. The data, as shown in Table A.11, were converted from thousand short-tons to quads. Savings were calculated by subtracting wood energy consumption for 1972 from wood energy consumption for each of the years in the study period. 
TABLE A.10. Calculation of Energy Use Reductions Due to Thermal Efficiency Improvements

(1)

$\begin{array}{ccc}\text { Year } & \begin{array}{c}\text { Percentage } \\ \text { increase in } \\ \text { Thermal Efficiency } \\ \text { vis-d-vis } 1972\end{array} \\ 1972 & & 0.00 \\ 1973 & & 0.00 \\ 1974 & & 3.26 \\ 1975 & & 4.45 \\ 1976 & & 4.88 \\ 1977 & & 5.80 \\ 1978 & 5.80 \\ 1979 & 5.80 \\ 1980 & 7.23 \\ 1981 & 9.25 \\ 1982 & 10.89\end{array}$

(2)

Reduction in Percentage Reduction in Space Heating Use Per Household (b)
vis-a-vis 1972

0.000

0.000

2.217

3.026

3.318

3.944

3.944

3.944

4.916

6.290

7.405
(3)

\begin{tabular}{|c|}
\hline $\begin{array}{c}\text { Electric Space Heating } \\
\text { Use Per Household } \\
\text { vis-a-vis } 1972 \text { (c) } \\
\text { (Million Btus) }\end{array}$ \\
\hline 0.000 \\
\hline 0.000 \\
\hline 2.696 \\
\hline 3.680 \\
\hline 4.035 \\
\hline 4.797 \\
\hline 4.797 \\
\hline 4.797 \\
\hline 5.979 \\
\hline 7.650 \\
\hline 9.006 \\
\hline
\end{tabular}

(4)

\begin{tabular}{c}
$\begin{array}{c}\text { Estimated Number } \\
\text { of Households With } \\
\text { Electric Space Heat ing (d) } \\
\text { (Millions) }\end{array}$ \\
\hline 7.470 \\
8.180 \\
8.920 \\
9.729 \\
10.481 \\
11.265 \\
12.236 \\
13.348 \\
14.149 \\
15.082 \\
16.037
\end{tabular}

NOTE: Use per household refers only to households with the identified characteristics. For example, Column 2 refers to per-household electricity use for space heating, given that the household is electrically heated.

(a) Calculated using a regression equation estimated using the NIECS/RECS databases for electrically heated and cooled homes in which thermal efficiency was related to electricity prices, income, and climate. The equation was evaluated here using aggregate U.S. data for the 1972-1982 period.

(b) Column 1 mutiplied by .68 , the estimated elasticity of space heating electricity demand with respect to thermal efficiency. Estinated using a subsample of the NIECS/RECS datasets, homes that were electrically heated.

(c) Column 2 (divided by 100) multiplies by 121.62, the estimated 1972 average electricity use for space heating per household.

(d) The product of the number of households and the percentage of homes heated electrically, which was estimated using the RECS database. 
TABLE A.10. (Continued)

(5)

\begin{tabular}{ccc} 
Year & $\begin{array}{c}\text { Space Hedting Electricity } \\
\text { Savings from Therma } \\
\text { Efficiency Inprovements } \\
\text { (Quadrillian Btus) }\end{array}$ \\
\cline { 1 - 1 } 1972 & 0.000 \\
1973 & 0.000 \\
1974 & 0.024 \\
1975 & 0.036 \\
1976 & 0.042 \\
1977 & 0.054 \\
1978 & 0.059 \\
1979 & 0.064 \\
1980 & 0.084 \\
1981 & 0.115 \\
1982 & 0.144
\end{tabular}

(6)

Reduction in

Non-electric Space Heating

Use per Household

vis-a-vis 1972
$(M i l l i o n$ Btus)

0.000

0.000

2.108

2.878

3.155

3.751

3.751

3.751

4.675

5.982

7.042
(7)

\begin{tabular}{c}
$\begin{array}{c}\text { Estimated Number } \\
\text { of Households with } \\
\text { Non-electric Space Heating }(g) \\
\text { (Millions) }\end{array}$ \\
\hline 59.453 \\
60.549 \\
61.665 \\
62.794 \\
63.524 \\
64.015 \\
64.931 \\
65.224 \\
65.923 \\
66.519 \\
73.057
\end{tabular}

(8)

Non-electric Space Heating Savings From Thermal Efficiency Improvements (h)

0.000

0.000

0.130

0.181

0.200

0.240

0.244

0.245

0.308

0.398

0.515

(e) Column mult iplied by column 4 .

(f) Column 2 (divided by 100) multiplied by 95.10, the estimated 1972 average gas use for space heating per household.

(g) The number of all occupied housing units minus Column 4.

(h) Column 6 multiplied by Column 7 . 
TABLE A.10. (Continued)

(10)

\begin{tabular}{|c|}
\hline $\begin{array}{l}\text { Percentage Reduction } \\
\text { in Electric } \\
\text { Space Cooling } \\
\text { Use Per Household }(i) \\
\text { vis-a-vis } 1972 \\
\end{array}$ \\
\hline 0.000 \\
\hline 0.000 \\
\hline 1.793 \\
\hline 2.448 \\
\hline 2.684 \\
\hline 3.190 \\
\hline 3.190 \\
\hline 3.190 \\
\hline 3.976 \\
\hline 5.087 \\
\hline 5.990 \\
\hline
\end{tabular}

0.000

0.000

0.653

0.892

0.964

1.162

1.162

1.162

1.448

1.853

2.182
Reduction in

Central Air Conditioning
Use Per Household

vis-d-vis $1972(\mathrm{j})$
(Million Btus)

Year

1972

1973

1974

1975

1976

1977

1978

1979

1980

1981

1982
(11)

(12)

\section{Est imated Number \\ of Households}

With Electric Central

Air Conditioning $(k)$

12.516

13.335

14.188

15.094

15.979

16.785

17.971

18.922

19.937

20.902

21.884
Central Air,

Conditioning Electricity Savings From Thermal
Efficiency Improvements

0.000

0.000

0.009

0.013

0.015

0.019

0.021

0.022

0.029

0.039

0.048

(i) Column 1 multiplied by .55 , the estimated elasticity of electric air conditioning demand with respect to thermal efficiency. Calculated in a similar manner to Colurnn 2.

(j) Column 9 divided by 100 , multiplied by 36.42 , the estimated average central AC electricity use per household in 1972.

(k) Estimated in a manner similar to Column 4.

(1) Column 10 multiplied by Column 11 . 
(13)

Reduction in Electric Room Air Conditioning Use Per Household vis-a-vis $1972(\mathrm{~m})$

Year

1972

1973

1974

1975

1976

1977

1978

1979

1980

1981

1982

0.000

0.000

0.285

0.390

0.422

0.508

0.508

0.508

0.633

0.810

0.954
(14)

$\begin{gathered}\text { Estimated Number } \\ \text { of Households } \\ \text { with Electric } \\ \text { Room Air Conditioners (n) } \\ \text { (Millions) }\end{gathered}$
$\begin{gathered}21.736 \\ 21.996 \\ 22.265\end{gathered}$

Room Air

Conditioning Electricity Savings From Thermal

Efficiency Improvements

vis-a-vis 1972
(Quadrillion Btus)
22.319

22.649

22.828

22.942

23.241

23.554

23.771

23.972
(16)

Total Electricity

Savings From Thermal

Efficiency Improvements

vis-a-vis 1972
(Quadrillion Btus)

0.000

0.000

0.169

0.239

0.267

0.325

0.336

0.343

0.436

0.571

0.730

(m) Column 9 divided by 15.92 , the estimated average room AC electricity use per household.

(n) Calculated in a manner similar to Column 4.

(o) Column 13 multiplied by Column 14 .

(p) Sum of Columns $5,8,12$ and 15 . 
TABLE A.11. Calculation of Residential Energy Savings Due to Increased Wood Use

\begin{tabular}{|c|c|c|c|}
\hline Year & $\begin{array}{l}\text { Fue } 1 \text { Wood } \\
\text { Consumption }(a) \\
(000 \text { short tons })\end{array}$ & $\begin{array}{l}\text { Fue } 1 \text { Wood } \\
\text { Consumption (b) } \\
\text { (quads) }\end{array}$ & $\begin{array}{l}\text { Energy Savings } \\
\text { Due to Wood Use } \\
\text { (quads) }\end{array}$ \\
\hline 1972 & 22,011 & 0.378589 & 0 \\
\hline 1973 & 20,524 & 0.353012 & -0.025577 \\
\hline 1974 & 21,505 & 0.369886 & -0.008703 \\
\hline 1975 & 24,651 & 0.423997 & 0.045408 \\
\hline 1976 & 27,912 & 0.480086 & 0.101497 \\
\hline 1977 & 31,394 & 0.539977 & 0.161388 \\
\hline 1978 & 36,039 & 0.619871 & 0.241282 \\
\hline 1979 & 42,171 & 0.725341 & 0.346757 \\
\hline 1980 & 47,360 & 0.814592 & 0.436003 \\
\hline 1981 & 48,026 & 0.826047 & 0.447458 \\
\hline 1982 & 52,498 & 0.902966 & 0.524377 \\
\hline
\end{tabular}

(a) EIA, Estimates of U.S. Wood Energy Consumption from 1949 to 1981 (b) 17.2 million Btu per short ton was used to convert from short tons to Btus Source: Pacific Northwest Laboratory 


\section{A.2.6 Other Considerations}

The remaining category to be estimated is the residual category which includes savings attributable to changes in household attitudes toward energy consumption and any other unspecified factors. In this analysis, the residual category is assumed to account for any savings remaining after the impacts of the other five factors have been evaluated. In terms of execution, each of the five factor lines is cumulatively subtracted from Line C (Figure A.2), and the remaining area between the wood use $l$ ine and Line $A$ is equal to the residual. 


\section{APPENDIX B}

COMMERCIAL ENERGY SAVINGS ESTIMATES: DETAILED METHODOLOGY 

APPENDIX B

\section{COMMERCIAL ENERGY SAVINGS ESTIMATES: DETAILED METHODOLOGY}

The development of estimates of post-embargo energy savings stemming from commercial building retrofit activity combines survey information, engineering model simulation results, and expert judgment. This appendix provides a detailed description of the methodology used to derive the summary results shown in Chapter 3.0 of the main report. Since judgment does enter into the final estimates, the objective of this appendix is to show clearly the interaction between the survey data and the judgmental factors.

\section{B.1 METHODOLOGICAL OVERVIEW}

Conceptually, the methodology employed is quite simple. First, the Nonresidential Building Energy Consumption Survey (NBECS) is used to provide data on the percentage of building stock (square feet) that had been retrofitted between 1972 and 1979. In this study, we specifically focus on: (1) weatherstripping or caulking, (2) additional roof or wall insulation, and (3) installation of tinted, reflective, or thermal pane windows. Unfortunately NBECS only asked building owners/managers whether or not these activities had taken place and not the magnitude of the action. Thus, for example, NBECS does not provide information as to the number of inches of insulation (or increase in R-value) that may have been added to the roof or wall. To fill in this gap, assumptions have been made as to the probable levels of these measures based on the judgment of architects and engineers at PNL familiar with commercial building energy conservation issues. To translate these assumptions into estimates of energy savings the DOE-2 energy use simulation model was employed. For each building prototype analyzed, the DOE-2 model was simulated for a baseline building configuration and then under conditions corresponding to the three retrofit actions listed above. A variety of simulations were performed to check the sensitivity of the results to variation over climate region and to the type of heating fuel (electricity or gas) used. The final step was to convert the energy savings estimates for a given building prototype into a national total estimate. This was accomplished by first computing 1979 
energy consumption across building type, climate region and heating fuel classifications and then applying percentage change factors to these figures based on the NBECS reported retrofit activity and the DOE-2 model results.

A serious limitation of our analysis is the lack of survey information with respect to the magnitude of the retrofit actions. In the development of the "common practice" assumptions for the pre- and post-embargo analysis, the choices of "typical" characteristics are assumed to reasonably match their mean values. Although the following tables display the savings results by building type, the reader is reminded that great significance should probably not be attached to these specific results. Alternatively, we believe that the engineering results, averaged across the eight prototypes, do reasonably reflect the range of savings in the aggregate stock. The detailed results are shown, in part, to allow the reader to roughly gauge the sensitivity of the aggregate savings estimates with regard to the assumptions on specific building types and retrofit actions.

Second, the analysis does not cover all building types in the commercial sector. Service stations, warehouses, hospitals, public buildings, hotels and motels were not included in the analysis. The omission of the first two may not be important as many of these buildings are not heated, or they are heated only at a minimal level. Hospitals are generally dominated by internal loads. Nevertheless, some additional savings would be expected if a complete analysis of all building types had been performed. The building types chosen for this study were dictated by suitable prototypes being available from prior related projects. To pursue the engineering approach with regard to these remaining building types would require a significant level of effort in developing such prototypes.

The third limitation, the extrapolation of aggregate savings estimates for 1981 and 1982, has already been discussed. Preliminary statistics from the second NBECS survey, which covers the period 1978-1983, is scheduled for release later in 1984. The new survey covers the same buildings as in the 1979 survey and should provide evidence as to whether conservation retrofit activity continued to show rapid growth beyond 1979. Unfortunately, the new survey does not ask the year in which the activity took place, and so only savings through 1983 could be computed. 
Some additional work with the existing survey may help to overcome the first two limitations discussed above. The detailed fuel consumption information by building type only became available in the final stages of the current project. This information was used to develop the baseline (1979) aggregate energy consumption by building type and weather zone. However, with this data it may be possible to develop a regression model (whose specification may be aided by the use of the DOE-2 engineering model) that would allow the effects of an "average" retrofit activity to be statistically estimated from the data. The fundamental question is whether sufficient information exists to hold other factors constant, such as weather variation, building configurations, and internal temperature. The survey does provide some limited qualitative information as to whether "reduced" cooling or heating had been undertaken since 1974. It also provides some data on the "normal" thermostat setting and heating and cooling degree days. Although this approach has been used with the residential survey data to infer the usage rates of particular appliances, no data until now have permitted a similar approach with commercial buildings. The approach appears to be a promising one and one that warrants further consideration.

The methodology just described can be divided into three major steps. The first step is the processing of the NBECS data tape to provide a measure of the building stock retrofitted between 1973-1979. The second step is to estimate probable energy savings for prototypical buildings. The final step is to combine the results from the prior steps into cumulative savings on a national basis. Each of these major steps is described in the sections below.

\section{B.2 BUILDINGS RETROFIT ACTIVITY}

This section describes the survey data and the manner in which information about building retrofits was extracted from the data.

\section{B.2.1 Description of NBECS}

The Nonresidential Building Energy Consumption Survey, conducted by the Energy Information Administration (EIA) in late 1979 and early 1980, is the first comprehensive survey of nonresidential buildings ever to be conducted in the United States. The survey covered over 6000 buildings throughout the U.S. 
The survey employed a multi-stage representative area probability sample of 79 primary sampling units (PSUs). Some 1900 PSUs were first made up of groups of counties and independent cities; all PSUs with 1970 population of 1.85 million were chosen as part of the final (79) first-stage sample. Subsequent stages were then used to go from the PSU level to zip code levels, and then finally to specific buildings.

Interviews were conducted with building owners or managers between October 1979 and January 1980. The interviews covered structural and operational building features; types of HVAC equipment; fuels used in these systems and patterns of usage; conservation retrofit actions; and a description of activities found in the building. In addition to the information from the interview, EIA also included fuel consumption information by building based on records from the building's fuel suppliers.

The results of the 1979 NBECS survey have been published in a series of reports beginning in 1981 . Table B.1 reproduces some summary results from the March 1983, report: 1979 Consumption and Expenditures, (Part 1: Natural Gas and Electricity). The published data breaks nonresidential buildings into 12 building types, with the largest consumption in the office and retail/services categories. On a per square foot basis, the food sales and health care are the most intensive energy users by building type.

\section{B.2.2 Extraction of Retrofit Data From NBECS}

The development of the retrofit activity time series (1973-1979) was based on the public use NBECS tape supplied by EIA. This consisted of 6222 records corresponding to the final set of buildings in the survey. Each record contained the coded responses for the several hundred questions that were part of the survey. In addition, a number of "external" data items were added by $E I A$ in the final construction of the tape. From these items, data values were extracted for the sample weight (used to "blow up" the figures to a national basis) and the weather zone category.

The first step in the data processing work was to create SAS (Statistical Analysis System) data files for each of the major building types of interest (see Table B.1). For each building type the amount of square footage that was affected by each of the three retrofit activities for each year was then 
TABLE B.1. Natural Gas and Electricity Consumption, and Expenditures for Commercial Buildings that Use Natural Gas or Electricity or Both: 1979

\begin{tabular}{|c|c|c|c|c|c|c|c|c|c|c|}
\hline $\begin{array}{c}\text { Dutiding } \\
\text { chancterstics }\end{array}$ & 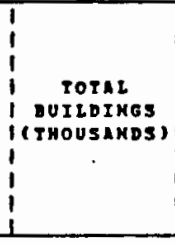 & 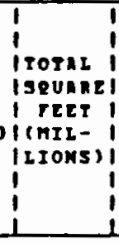 & 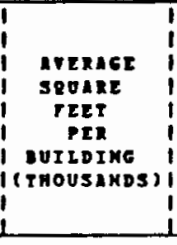 & 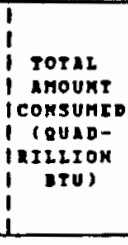 & 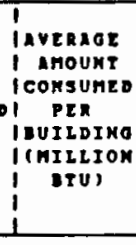 & 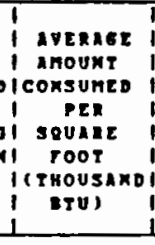 & 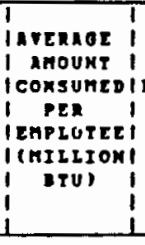 & \begin{tabular}{|l|} 
TOTAL \\
ExPEA. \\
(NIL- \\
LIOX \\
DOL- \\
IARS
\end{tabular} & 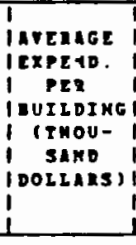 & 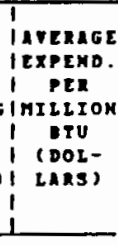 \\
\hline \multicolumn{11}{|l|}{ SHSA/MONSMSA } \\
\hline $\begin{array}{l}\text { snsa } \ldots \ldots \ldots \ldots \ldots \ldots \ldots \ldots \ldots \\
\text { nonsrsi } \ldots \ldots \ldots \ldots \ldots \ldots \ldots \ldots\end{array}$ & $\begin{array}{l}2.221 \\
1.654\end{array}$ & $\begin{array}{l}33,060 \\
13,037\end{array}$ & $\begin{array}{r}15.2 \\
6.1\end{array}$ & $\begin{array}{l}3.379 \\
1.071\end{array}$ & $\begin{array}{r}1.521 \\
647\end{array}$ & 100 & 69 & $\begin{array}{r}25.049 \\
7.426\end{array}$ & $\begin{array}{r}11.3 \\
1.5\end{array}$ & $\begin{array}{l}7.41 \\
6.94\end{array}$ \\
\hline \multicolumn{9}{|l|}{ HEATIMO AMD COOLINO } & & \\
\hline $\begin{array}{l}\angle 2,000 \text { CDO AMD }>7.000 \text { NDD... } \\
<2,000 \text { CDD AMD } 5.500 \text { TO }\end{array}$ & 137 & 5,086 & 18.6 & .075 & 1.089 & 17 & 1 & 2.901 & 6.6 & 6.10 \\
\hline 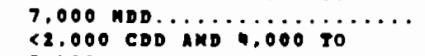 & 1.142 & 16.667 & 10.1 & 1.688 & 1,070 & 105 & $\mathbf{m}$ & 10.923 & 9.6 & 1.47 \\
\hline 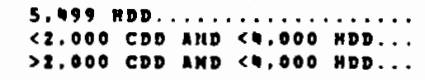 & $\begin{array}{r}1.046 \\
627 \\
623\end{array}$ & $\begin{array}{r}12,743 \\
6.936 \\
6.073\end{array}$ & $\begin{array}{r}12.2 \\
11.1 \\
1.7\end{array}$ & $\begin{array}{l}1.060 \\
.660 \\
.566\end{array}$ & $\begin{array}{r}1.013 \\
1.030 \\
900\end{array}$ & $\begin{array}{l}13 \\
95 \\
93\end{array}$ & $\begin{array}{l}62 \\
11\end{array}$ & $\begin{array}{l}1.040 \\
1.723 \\
0.09\end{array}$ & $\begin{array}{l}1.6 \\
7.5 \\
7.8\end{array}$ & $\begin{array}{l}1.53 \\
7.15 \\
. .64\end{array}$ \\
\hline \multicolumn{11}{|l|}{ BUILDIKG TTPE } \\
\hline Assemety. . . . . . . . . . & 143 & 5,020 & 11.3 & .329 & 740 & $\$ 6$ & 100 & 2,161 &.. & 6.57 \\
\hline AUTOHOTIVE SALES C EERYCE. & 397 & 1,799 & 0.5 & .172 & 434 & 96 & 72 & 1.227 & 3. 1 & 7.13 \\
\hline roucation $\ldots \ldots \ldots \ldots \ldots \ldots$ & 161 & 5.151 & 36.2 & .373 & 2.300 & 6 & 1 & 2,460 & 13.3 & 6.62 \\
\hline rood sALES $\ldots \ldots \ldots \ldots \ldots \ldots$ & 365 & 1.860 & 3. 1 & .322 & 832 & 173 & 78 & 2,707 & 7.4 & .041 \\
\hline 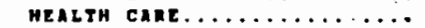 & 4 & 1.607 & 36.3 & .301 & 6.889 & 179 & 74 & 1.693 & 38.7 & 5.62 \\
\hline LODGING $\ldots \ldots \ldots \ldots \ldots \ldots$ & 101 & 2.012 & 19.9 & .225 & 2.227 & 112 & 124 & 1.609 & 16.0 & 7.16 \\
\hline ortice $\ldots \ldots \ldots \ldots \ldots \ldots \ldots$ & 594 & 0.183 & 13.7 & .041 & 1.403 & 103 & 36 & 7,537 & 12.6 & $\bullet .97$ \\
\hline 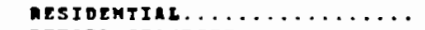 & 347 & 3,115 & 9.0 & .186 & 534 & 60 & 1 & 1.285 & 3.7 & $\bullet .09$ \\
\hline RETAIL/SERVICES . . & 714 & 7.652 & 10.7 & .595 & 833 & 78 & 64 & 0.596 & 6.4 & 7.72 \\
\hline MAREMOUSE AMD STORAGE $\ldots \ldots$ & 366 & 5.967 & 16. & .563 & 1.541 & 94 & 134 & 3.725 & 10.2 & 6.61 \\
\hline 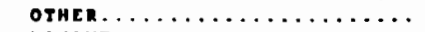 & 230 & 3,112 & 13.6 & .479 & 2,087 & 154 & 104 & 2.941 & 12.8 & 6.10 \\
\hline VACANT............... & 108 & 1.026 & 9.3 & .063 & 579 & 6 & 398 & 525 & 4.9 & 8.39 \\
\hline \multicolumn{11}{|l|}{ TOTAL SQUARE TOOTAGE } \\
\hline 1,000 on Less $\ldots \ldots \ldots \cdots \cdots \cdots$ & $\begin{array}{r}600 \\
623\end{array}$ & 342 & .6 & .097 & $16:$ & 205 & 67 & $\begin{array}{r}992 \\
753\end{array}$ & 1.6 & 10.00 \\
\hline 5,001 to $10,000 \ldots \ldots \ldots \ldots \ldots \ldots$ & $\begin{array}{r}1.623 \\
733\end{array}$ & 5,271 & $\begin{array}{l}2.7 \\
7.2\end{array}$ & .505 & 689 & 96 & 70 & 3.390 & 4.6 & 6.71 \\
\hline $\begin{array}{l}10,001 \text { to } 25,000 \ldots \ldots \ldots \ldots \\
25,009 \text { T0 } 50,000 \ldots \ldots \ldots \ldots\end{array}$ & $\begin{array}{l}54 r \\
204\end{array}$ & $\begin{array}{l}8.628 \\
7.201\end{array}$ & $\begin{array}{l}15.7 \\
35.2\end{array}$ & $\begin{array}{l}.850 \\
.581\end{array}$ & $\begin{array}{l}1,549 \\
2.844\end{array}$ & 99 & $\begin{array}{l}78 \\
81\end{array}$ & $\begin{array}{l}5.397 \\
5.169\end{array}$ & $\begin{array}{r}9.1 \\
25.3\end{array}$ & $\begin{array}{l}6.35 \\
1.90\end{array}$ \\
\hline oven $50.000 \ldots \ldots \ldots \ldots \ldots$ & 165 & 21.448 & 129. & 1.107 & 10.939 & 14 & 64 & 12,704 & 77.4 & 7.08 \\
\hline \multicolumn{11}{|l|}{ MUHBER Or TroONS } \\
\hline OKE TLOOA..... & 2.217 & 13.062 & 6.3 & 1.301 & 614 & 90 & 71 & 10.632 & 1.0 & 7.81 \\
\hline $\begin{array}{l}\text { THO TLOORS } \ldots \ldots \ldots \ldots \ldots \cdots \cdots \\
\text { THREE TLOORS } \ldots \ldots \ldots \ldots \ldots \ldots\end{array}$ & $\begin{array}{l}900 \\
480\end{array}$ & $\begin{array}{r}11.601 \\
1.133\end{array}$ & $\begin{array}{l}12.9 \\
17.0\end{array}$ & $\begin{array}{r}1.032 \\
.634\end{array}$ & $\begin{array}{l}1.147 \\
1.322\end{array}$ & 89 & $\begin{array}{l}78 \\
71\end{array}$ & $\begin{array}{l}7.149 \\
4.277\end{array}$ & $\begin{array}{l}7.9 \\
199\end{array}$ & $\begin{array}{l}6.93 \\
6.75\end{array}$ \\
\hline MORE THAK THEEE $\ldots \ldots \ldots \ldots \ldots$ & 278 & 13.708 & 10.3 & 1.422 & 5.119 & 104 & 64 & 10.418 & 37.5 & 7.33 \\
\hline
\end{tabular}

SOURCE: Energy Information Administration (1979). 
computed. Thus for a given observation we first determined whether insulation had been added or not. If yes, then square footage represented by this observation was calculated as the product of the sample weight and the square footage for this particular building. The square footage for the year in which the activity was undertaken was then accumulated over all observations. Finally these values were converted to percentages of total building floor space and then cumulated over the years 1973 through 1979. This process was repeated for each building type, size, weather zone, and heating fuel category.

Because of the lack of readily available building prototypes for the DOE-2 energy model, not all building types were covered by the analysis. The retrofit activity measures were computed for the categories shown in Table B.2. Buildings within these categories accounted for some 60 percent of total commercial floorspace in 1979.

Tables B.3 through B.26 show the cumulative percentage of floorspace covered by the retrofit actions in the study. Each retrofit activity (i.e., caulking, insulation, and window replacement) is presented for each building type.

\section{B.3 ENERGY SAVINGS IN PROTOTYPICAL BUILDINGS}

The DOE-2 engineering energy use model was used to estimate the probable energy savings from each retrofit activity. For each building type, a set of specifications regarding the building shell was established to correspond with "pre-embargo" design practices. Assumptions were then made regarding the type and extent of energy conservation activities which were part of the NBECS survey. Table B.27 tabulates these assumptions for each building type and measure. The relationship between the mean size within each category and the size of the prototype is shown in Table B.2.

For the most part, these assumptions regarding building shell specifications were based on design guidelines issued by the American Society of Heating, Refrigeration, and Air Conditioning Engineers (ASHRAE). This approach was taken after some preliminary work (through contacts with several public agencies and private architect-engineer firms) to gather information provided only fragmentary data. Since the ASHRAE standards are widely followed 
TABLE B.2. Building Categories Used in Commercial Analysis

\begin{tabular}{|c|c|c|c|c|}
\hline Category & $\begin{array}{c}\text { Range } \\
\text { (sq. ft.) }\end{array}$ & $\begin{array}{l}\text { \% Floor space } \\
\text { within Major } \\
\text { Tyoe } \\
\end{array}$ & $\begin{array}{l}\text { Ave. Size } \\
\text { (sq. ft.) }\end{array}$ & $\begin{array}{c}\text { Size of } \\
\text { Prototype }\end{array}$ \\
\hline Assembly & ---- & 100 & 11,200 & 10,000 \\
\hline Education & $-\cdots$ & 100 & 36,200 & 40,500 \\
\hline Food Sales - small & $<5000$ & 31 & 2,069 & 2,260 \\
\hline Food Sales - large & $>5000$ & 69 & 14,450 & 10,000 \\
\hline Office - small & $<150,000$ & 65 & 8,979 & 20,000 \\
\hline Office - large & $>150,000$ & 35 & 380,400 & 376,800 \\
\hline Retail/Service-smal1 & $<50,000$ & 60 & 6,635 & 6,350 \\
\hline Retail/Service-large & $>50,000$ & 40 & 142,338 & 120,000 \\
\hline
\end{tabular}


TABLE B.3. Historical Retrofit Activity, Caulking and Weatherstripping, in Assembly Buildings

hEATED BY: MATURAl GAS, FUEL OIL, LPG, OR STEAM

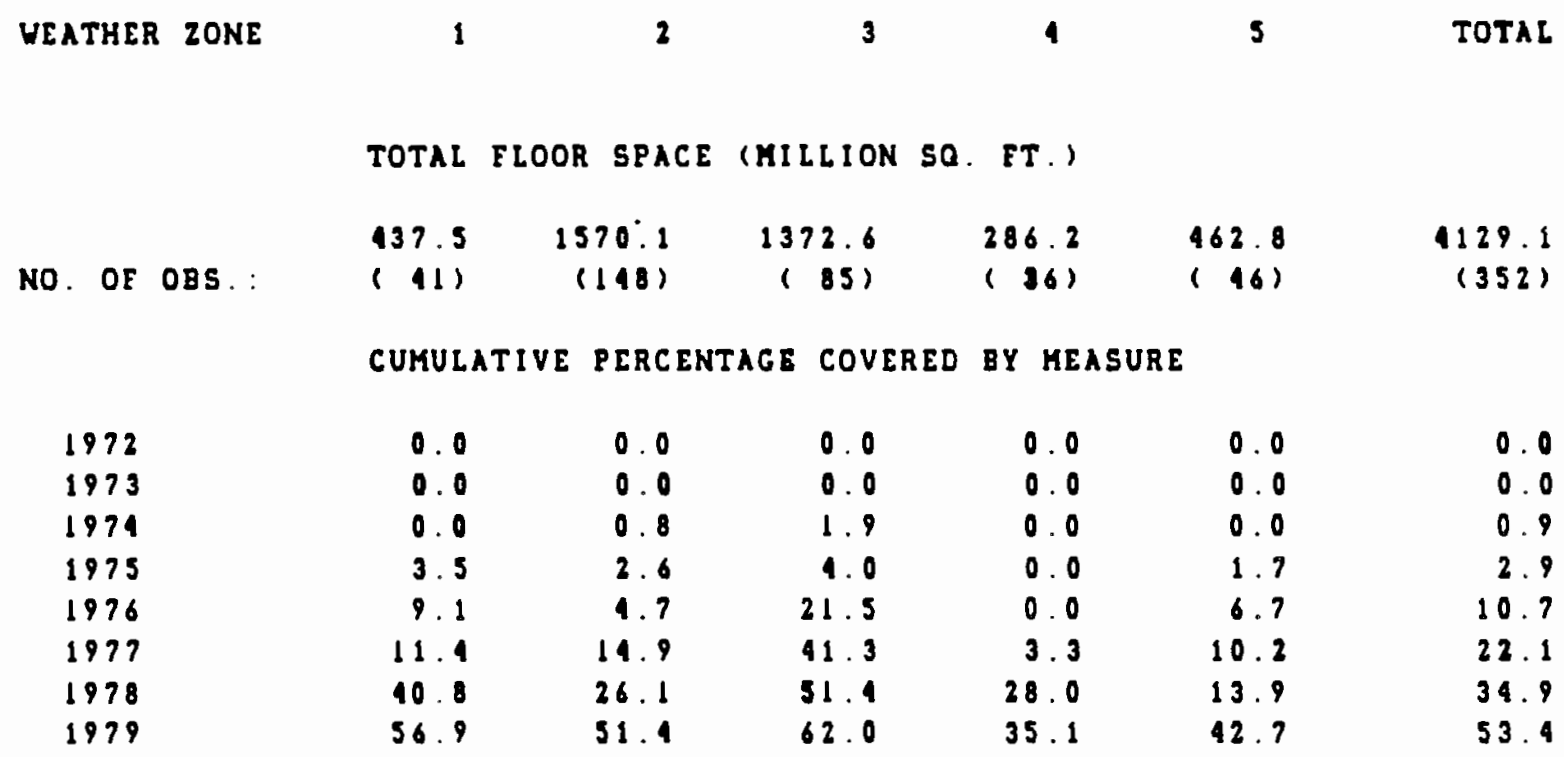

HEATED BY: ELECTRICITY

WEATHER ZONE

1

2

3

1

$\mathbf{5}$

TOTAL

TOTAL FLOOR SPACE (MILLION SQ. ET.)

\begin{tabular}{|c|c|c|c|c|c|c|}
\hline & 56.4 & 198.1 & 273.3 & 183.8 & 186.6 & 898.2 \\
\hline O. OF OBS & $(5)$ & $(19)$ & $(25)$ & $(23)$ & $(25)$ & $(97)$ \\
\hline
\end{tabular}

CUMULATIVE PERCENTAGE COVERED BY MEASURE

$\begin{array}{lrrrrrr}1972 & 0.0 & 0.0 & 0.0 & 0.0 & 4.0 & 0.8 \\ 1973 & 0.0 & 0.0 & 0.0 & 15.3 & 4.0 & 3.9 \\ 1979 & 0.0 & 0.0 & 0.0 & 15.3 & 4.0 & 3.9 \\ 1975 & 0.0 & 0.0 & 0.0 & 15.3 & 4.0 & 3.9 \\ 1976 & 0.0 & 11.1 & 0.0 & 15.3 & 7.1 & 7.1 \\ 1979 & 0.0 & 22.6 & 14.5 & 16.8 & 11.9 & 15.3 \\ 1978 & 28.9 & 17.3 & 43.3 & 16.8 & 47.4 & 38.7 \\ 1979 & 28.9 & 17.3 & 52.2 & 51.6 & 47.9 & 48.6\end{array}$


TABLE B.4. Historical Retrofit Activity, Insulation, in Assembly Buildings

HEATED BY: NATURAL GAS, FUEL OIL, LPG, OR STEAM

VEATHER ZONE

1

2

3

$\mathbf{s}$

TOTAL

TOTAL FLOOR SPACE (MILLION SO. FT.)

NO. OE OBS.:

$\begin{array}{llll}137.5 & 1570.1 & 1372.6 & 286.2\end{array}$

462.8

4129.1

(41)

(148)

( 85$)$

(36)

$(46)$

(352)

CUmulative PERCENTAGe COVERED by measure

$\begin{array}{lrrrrrr}1972 & 0.0 & 0.7 & 0.0 & 0.0 & 0.0 & 0.3 \\ 1973 & 0.0 & 2.1 & 0.0 & 0.0 & 0.0 & 0.8 \\ 1974 & 0.0 & 2.2 & 0.0 & 0.0 & 0.0 & 0.8 \\ 1975 & 0.0 & 1.0 & 0.4 & 0.0 & 0.8 & 1.8 \\ 1976 & 3.3 & 6.9 & 1.3 & 1.5 & 0.8 & 3.5 \\ 1977 & 6.6 & 11.9 & 5.5 & 1.5 & 0.8 & 7.1 \\ 1978 & 1.7 & 16.3 & 15.5 & 9.1 & 3.9 & 13.3 \\ 1979 & 9.7 & 34.2 & 20.1 & 9.1 & 29.0 & 24.6\end{array}$

HEATED BY: ELECTRICITY

WEATHER 2ONE

1

2

3

4

TOTAL

TOTAL FLOOR SPACE (MILLION SO. FT.)

NO. OF OBS.:

$\begin{array}{cccccc}56.9 & 198.1 & 273.3 & 183.8 & 186.6 & 898.2 \\ (5) & (19) & (25) & (23) & (25) & (97)\end{array}$

CUMULATIVE PERCENTACE COVERED BY MEASURE

$\begin{array}{lrrrrrr}1972 & 0.0 & 0.0 & 0.0 & 0.0 & 0.6 & 0.1 \\ 1973 & 0.0 & 0.0 & 0.0 & 0.0 & 0.6 & 0.1 \\ 1974 & 0.0 & 0.0 & 0.0 & 0.0 & 0.6 & 0.1 \\ 1975 & 0.0 & 11.9 & 3.1 & 0.0 & 0.6 & 1.1 \\ 1976 & 0.0 & 11.9 & 3.1 & 0.0 & 0.6 & 1.4 \\ 1977 & 0.0 & 18.2 & 28.3 & 0.0 & 16.1 & 17.5 \\ 1978 & 28.9 & 21.2 & 28.3 & 0.0 & 16.1 & 20.4 \\ 1979 & 17.0 & 21.2 & 30.0 & 49.9 & 25.3 & 32.2\end{array}$


TABLE B.5. Historical Retrofit Activity, Window

Replacement, in Assembly Buildings

WEATHER ZONE

HEATED By: matURAL GAS, fUEL OIL, LPG, OR STEAM

1

2

3

4

3

TOTAL

TOTAL ELOOR SPACE (MILLION SO. ET.)

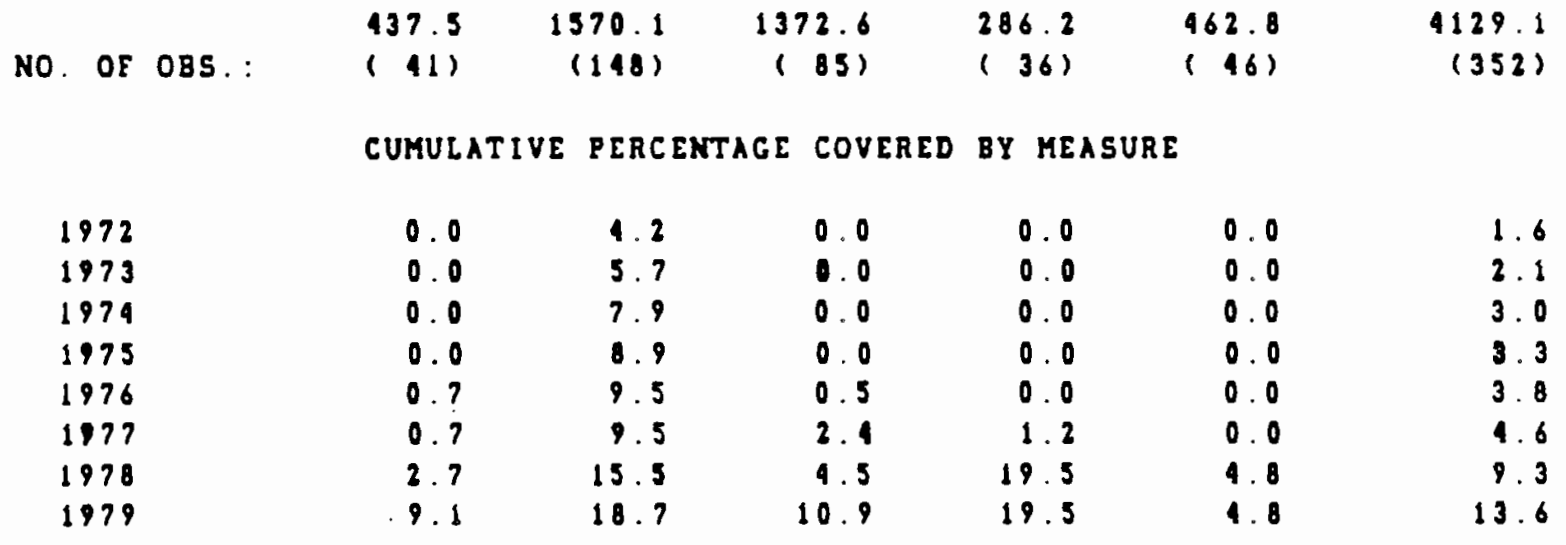

HEATED BY: ELECTRICITY

WEATHER ZONE

1

2

3

4

TOTAL

TOTAL ELOOR SPACE (MILLION SO. ET.)

$\begin{array}{lcccccc}\text { NO. } 0 \text { 085.: } & 56.4 & 198.1 & 273.3 & 183.8 & 186.6 & 898.2 \\ & (5) & (19) & (25) & (23) & (25) & (97) \\ 1972 & \text { CUMULATIVE } & \text { PERCENTAGE COVERED BY MEASURE } \\ 1973 & 0.0 & 0.0 & 0.0 & 0.0 & 0.4 & 0.1 \\ 1974 & 0.0 & 0.0 & 0.0 & 0.0 & 1.4 & 0.3 \\ 1975 & 0.0 & 0.0 & 0.0 & 0.0 & 1.4 & 0.3 \\ 1976 & 17.2 & 0.0 & 0.0 & 1.4 & 1.4 & 1.6 \\ 1977 & 17.2 & 0.0 & 0.0 & 1.1 & 1.4 & 1.6 \\ 1978 & 17.2 & 2.4 & 0.0 & 1.1 & 6.2 & 3.2 \\ 1979 & 17.2 & 2.4 & 1.7 & 1.4 & 29.6 & 8.6 \\ & 16.1 & 2.4 & 1.7 & 19.8 & 33.0 & 14.9\end{array}$


TABLE B.6. Historical Retrofit Activity, Caulking and Weatherstripping, in Education Buildings

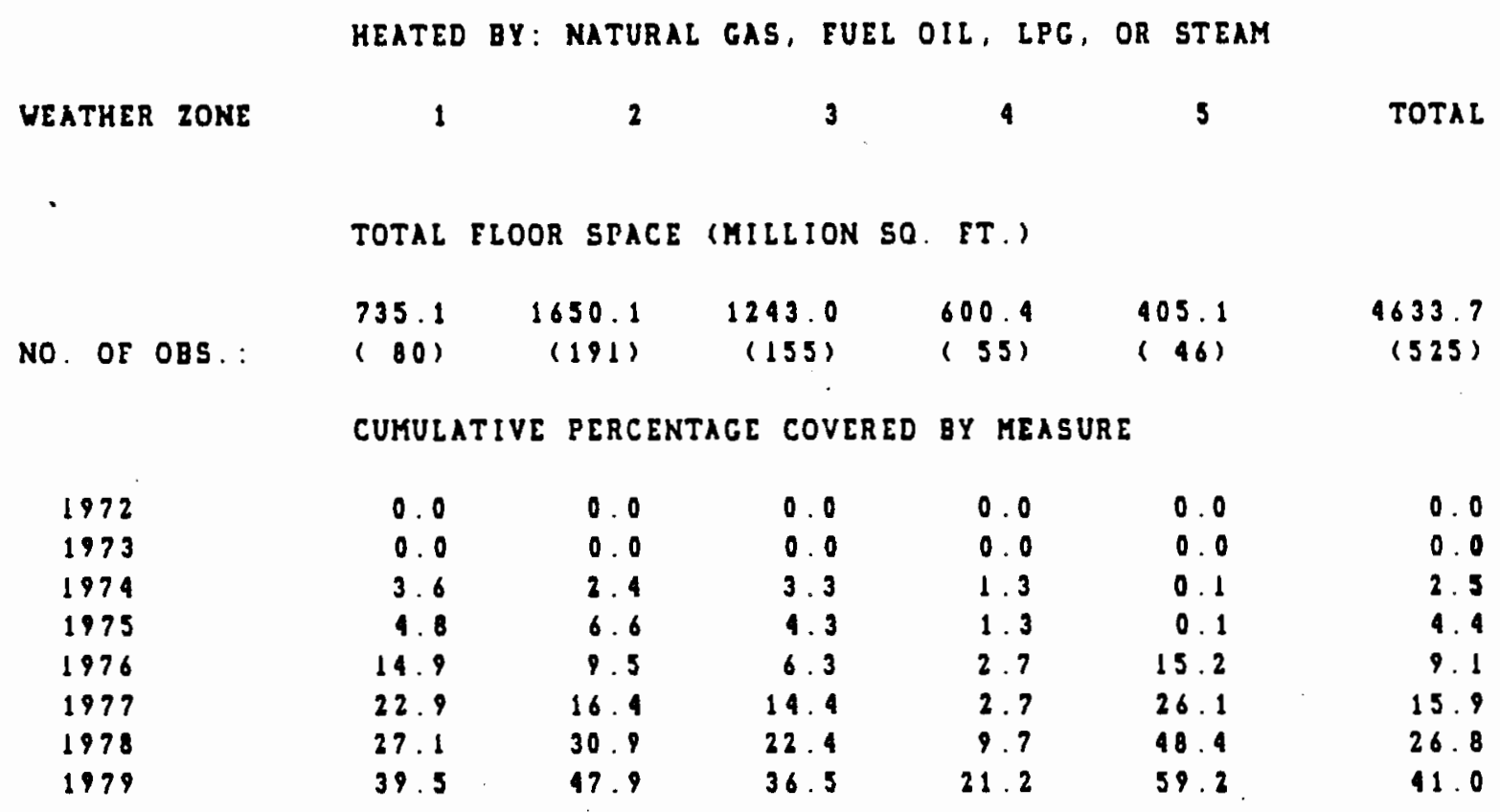

HEATED BY: ELECTRICITY

WEATHER ZONE

1

2

3

4

5

TOTAL

TOTAL FLOOR SPACE (MILLION SO. FT.)

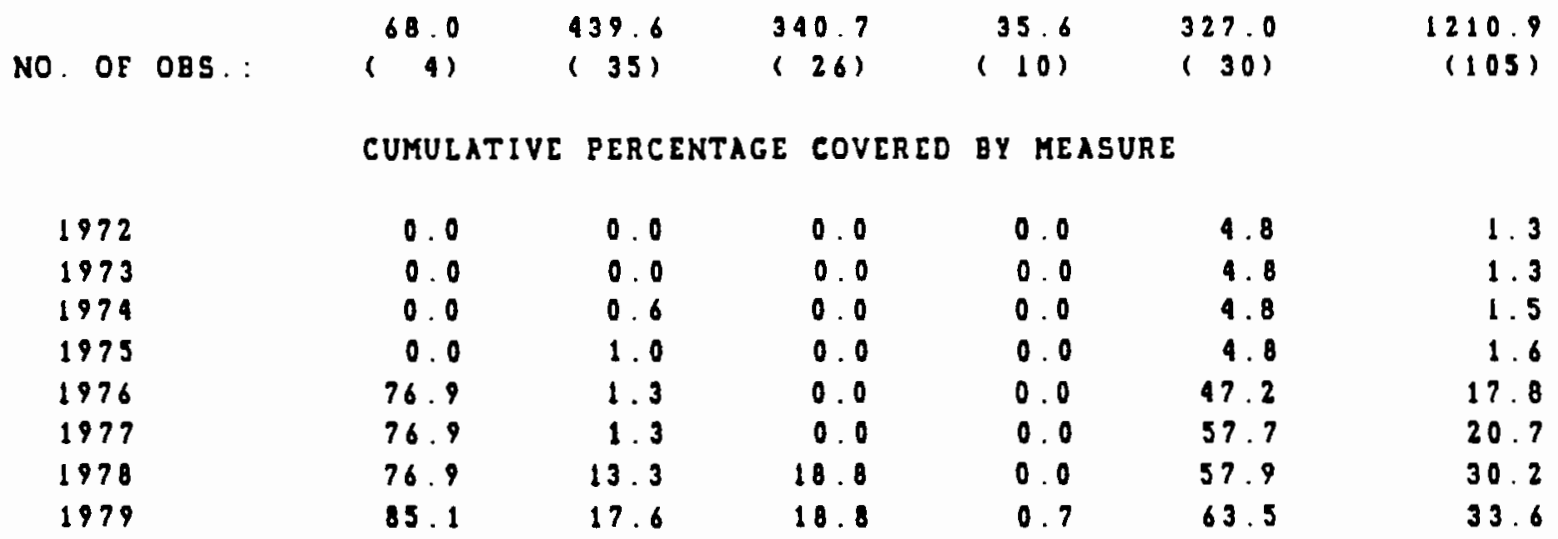


TABLE B.7. Historical Retrofit Activity, Insulation, in Education Buildings

HEATED BY: NATURAL GAS, FUEL OIL, LPG, OR STEAH

WEATHER ZONE

1

2

3

4

5

TOTAL

TOTAL FLOOR SPACE (MILIION SQ. ET.)

$\begin{array}{cccccc}735.1 & 1650.1 & 1243.0 & 600.4 & 405.1 & 4633.7 \\ (80) & (191) & (155) & (55) & (46) & (525)\end{array}$

CUKULATIVE PERCENTACE COVERED BY MEASURE

$\begin{array}{lrrrrrr}1972 & 0.0 & 0.2 & 0.0 & 0.0 & 0.0 & 0.1 \\ 1973 & 0.0 & 0.2 & 0.1 & 0.0 & 0.0 & 0.2 \\ 1979 & 0.0 & 1.0 & 1.3 & 0.0 & 0.0 & 1.4 \\ 1975 & 1.5 & 3.3 & 8.3 & 0.0 & 10.4 & 4.5 \\ 1976 & 11.7 & 5.8 & 0.3 & 0.0 & 10.9 & 7.2 \\ 1977 & 19.4 & 8.1 & 12.0 & 1.7 & 11.4 & 9.7 \\ 1978 & 19.9 & 14.8 & 15.0 & 6.8 & 15.0 & 14.7 \\ 1979 & 22.1 & 22.9 & 22.2 & 7.2 & 19.6 & 20.3\end{array}$

HEATED BY: ELECTRICITY

WEATHER ZONE

1

2

3

4

TOTAL

TOTAL FLOOR SPACE (MILLION SO. ET.)

NO. OF OBS.:

$\begin{array}{rrrrrr}68.0 & (39.6 & 340.7 & 35.6 & 327.0 & (210.9 \\ (4) & (35) & (26) & (10) & (30) & (105)\end{array}$

CUMULATIVE PERCENTAGE COVERED BY MEASURE

$\begin{array}{lllllll}1972 & 0.0 & 0.0 & 0.0 & 0.0 & 9.8 & 1.3 \\ 1973 & 0.0 & 0.0 & 0.0 & 0.0 & 4.8 & 1.3 \\ 1974 & 0.0 & 0.0 & 0.0 & 0.0 & 4.8 & 1.3 \\ 1975 & 0.0 & 0.0 & 0.0 & 0.0 & 9.8 & 1.3 \\ 1976 & 0.0 & 1.6 & 1.1 & 0.0 & 4.8 & 2.2 \\ 1977 & 0.0 & 1.6 & 1.1 & 0.0 & 4.8 & 2.2 \\ 1978 & 0.0 & 2.1 & 14.5 & 0.0 & 15.5 & 9.0 \\ 1979 & 0.0 & 2.3 & 14.5 & 0.0 & 17.8 & 9.7\end{array}$


TABLE B.8. Historical Retrofit Activity, Window Replacement, in Education Buildings

hEATEd gY: matural Gas, fUEL OIL, LfG, OR STEAm

WEATHER ZONE

1

2

3

4

5

TOTAL

TOTAL FLOOR SPACE (MILLION SQ. FT.)

NO. OF OBS.:

$735.1 \cdot 1650.1 \quad 1243.0 \quad 600.4 \quad 405.1$

4633.7

$(80)$

$(191)$

(155)

$(55)(96)$

(525)

CUMULATIVE PERCENTAGE COVERED BY meASURE

$\begin{array}{lllllll}1972 & 0.0 & 0.3 & 0.0 & 0.0 & 0.0 & 0.1 \\ 1973 & 0.5 & 0.3 & 0.0 & 0.0 & 0.0 & 0.2 \\ 1974 & 3.8 & 2.3 & 0.0 & 0.0 & 11.5 & 2.6 \\ 1975 & 3.8 & 3.5 & 0.0 & 2.7 & 11.5 & 3.3 \\ 1976 & 6.3 & 1.5 & 0.0 & 4.3 & 11.5 & 3.9 \\ 1977 & 8.2 & 4.9 & 0.0 & 4.3 & 15.9 & 5.1 \\ 1978 & 9.0 & 6.1 & 1.0 & 5.1 & 15.9 & 6.0 \\ 1979 & 14.0 & 7.9 & 3.1 & 8.0 & 15.9 & 8.3\end{array}$

HEATED BY: ELECTRICITY

UEATHER ZONE

1

2

3

4

$s$

TOTAL

TOTAL FLOOR SPACE (MILLION SQ. FT.)

\begin{tabular}{|c|c|c|c|c|c|c|c|}
\hline \multirow{2}{*}{ NO. OE OBS } & 68.0 & 439.6 & 340.7 & \multicolumn{2}{|c|}{35.6} & 327.0 & \multirow{2}{*}{$\begin{array}{r}1210.9 \\
(105)\end{array}$} \\
\hline & (4) & $(35)$ & 26) & 110 & & $(30)$ & \\
\hline & CUMUL & PERC & $\operatorname{cov}$ & BY $\mathrm{M}$ & AEASURE & & \\
\hline 1972 & 0.0 & 0.5 & 0.0 & 0. & 0 & 4.8 & 1.5 \\
\hline 1973 & 0.0 & 0.5 & 0.0 & & 0 & 4. 8 & 1.5 \\
\hline 1974 & 0.0 & 0.5 & 2.3 & 0. & 0 & 4.8 & 2.1 \\
\hline 1975 & 0.0 & 1.1 & 2.3 & 0. & 0 & 4.8 & 2. 3 \\
\hline 1976 & 0.0 & 1.1 & 2.3 & 0. & 0 & 8.0 & 3.2 \\
\hline $197 ?$ & 0.0 & 1.1 & 2.3 & 0. & 0 & 11.0 & 4.0 \\
\hline 1978 & 0.0 & 1.6 & 2.3 & 0. & 0 & 11.0 & 4.2 \\
\hline 1979 & 0.0 & 2.6 & 2. 3 & 0. & 0 & 20.4 & 7.1 \\
\hline
\end{tabular}


TABLE B.9. Historical Retrofit Activity, Caulking and Weatherstripping, in Small Food Sales Buildings

HEATED BY: NATURAL GAS, FUEL OIL, IPG, OR STEAM

WEATHER ZONE

1

2

3

4

5

TOTAL

TOTAL FLOOR SPACE (MILLION SO. FT.)

\begin{tabular}{|c|c|c|c|c|c|c|}
\hline & 56.9 & 122.7 & 76.5 & 04.7 & 44.4 & 385.2 \\
\hline OF OBS.: & $(20)$ & $(37)$ & $(38)$ & $(33)$ & $(25)$ & $(152)$ \\
\hline
\end{tabular}

CUMULATIVE PERCENTAGE COVERED BY MEASURE

$\begin{array}{lrrrrrr}1972 & 0.0 & 0.0 & 0.0 & 0.0 & 0.0 & 0.0 \\ 1973 & 0.0 & 0.0 & 0.0 & 0.0 & 0.0 & 0.0 \\ 1974 & 5.0 & 0.0 & 0.0 & 0.0 & 0.0 & 0.8 \\ 1975 & 5.0 & 0.0 & 0.0 & 0.0 & 0.7 & 0.9 \\ 1976 & 9.8 & 0.0 & 0.1 & 0.0 & 0.7 & 1.6 \\ 1977 & 13.1 & 13.2 & 6.3 & 0.0 & 0.7 & 1.5 \\ 1978 & 14.2 & 23.3 & 21.7 & 4.7 & 16.3 & 16.0 \\ 1979 & 27.5 & 34.5 & 37.1 & 19.1 & 16.3 & 28.2\end{array}$

WEATHER ZONE

HEATED BY: ELECTRICITY

1

2

3

4

5

TOTAL

TOTAL FLOOR SPACE (MILLION SO. FT.)

NO. OF OBS.: $\quad \begin{array}{rrrrrr}3.8 & 26.4 & 96.9 & 38.0 & 66.3 & 183.5 \\ 25 & (2) & (15) & (10) & (24) & (60)\end{array}$

CUMULATIVE PERCENTAGE COVERED BY MEASURE

$\begin{array}{lllllll}1972 & 0.0 & 0.0 & 0.0 & 0.0 & 0.0 & 0.0 \\ 1973 & 0.0 & 0.0 & 0.0 & 0.0 & 0.0 & 0.0 \\ 1974 & 0.0 & 0.0 & 0.0 & 0.0 & 3.2 & 1.0 \\ 1975 & 0.0 & 0.0 & 0.0 & 0.0 & 3.2 & 1.0 \\ 1973 & 0.0 & 0.0 & 0.0 & 14.7 & 3.2 & 4.3 \\ 1977 & 0.0 & 0.0 & 0.0 & 34.2 & 10.1 & 10.8 \\ 1978 & 0.0 & 18.8 & 16.6 & 50.3 & 33.2 & 29.1 \\ 1979 & 0.0 & 10.8 & 34.4 & 60.1 & 38.4 & 37.0\end{array}$


TABLE B.10. Historical Retrofit Activity, Insulation, in Small Food Sales Buildings

heATED oy: matURal Gas, fUEL OIL, LPG, OR STEAM

WLATHER ZONE

1

2

3

4

5

TOTAL

TOTAL FLOOR SPACE (MILLION SO. FT.)

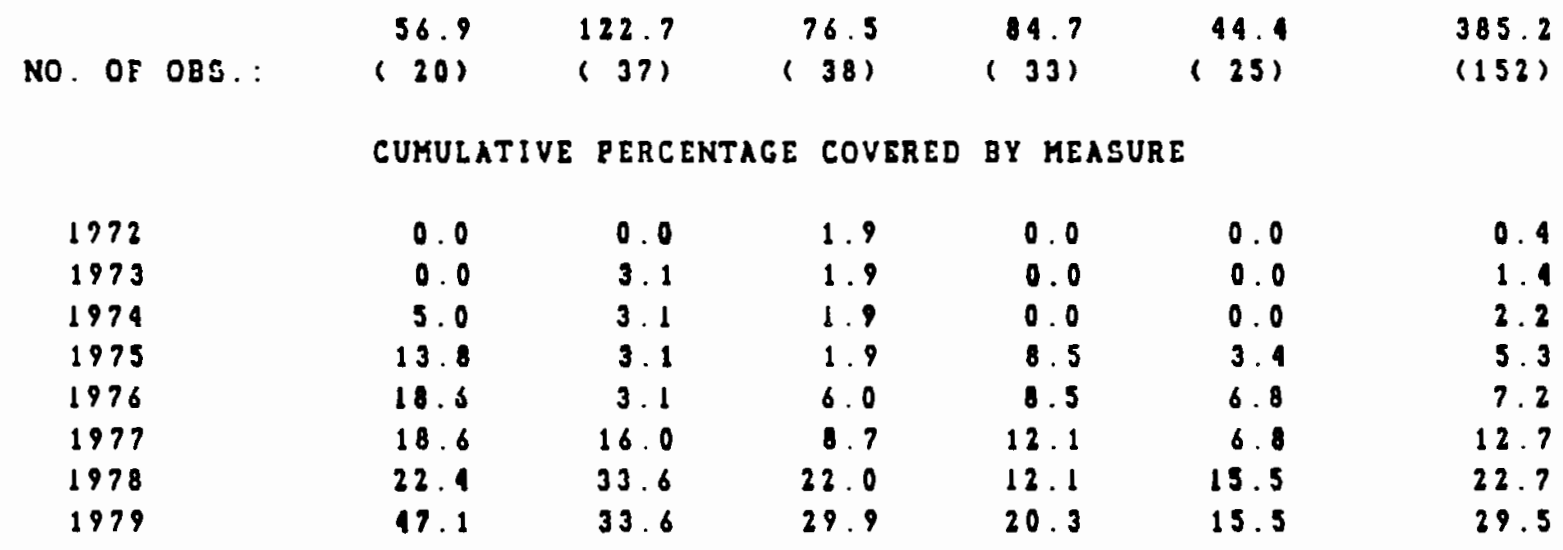

HEATED BY. ELECTRICITY

VEATHER ZONE

1

2

3

4

5

TOTAL

TOTAL FLOOR STACE (MILLION SO. FT.)

No. OF O8S.: $\quad \begin{array}{cccccc}5.8 & 26.4 & 46.9 & 38.0 & 66.3 & 183.5 \\ 25 & (8) & (18) & (10) & (24) & (60)\end{array}$

CUMULATIVE PERCENTAGE COVERED gY MEASURE

$\begin{array}{lrrrrrr}1972 & 0.0 & 0.0 & 0.0 & 0.0 & 0.0 & 0.0 \\ 1973 & 0.0 & 0.0 & 4.1 & 0.0 & 0.0 & 1.0 \\ 1974 & 0.0 & 0.0 & 1.1 & 0.0 & 0.0 & 1.0 \\ 1975 & 0.0 & 0.0 & 4.1 & 0.0 & 3.0 & 2.0 \\ 1976 & 0.0 & 0.0 & 1.1 & 14.7 & 6.9 & 6.8 \\ 1977 & 0.0 & 14.6 & 1.1 & 14.7 & 6.9 & 9.2 \\ 1978 & 0.0 & 18.8 & 10.3 & 14.7 & 26.1 & 18.0 \\ 1979 & 0.0 & 18.8 & 19.6 & 14.7 & 32.2 & 22.1\end{array}$


TABLE B.11. Historical Retrofit Activity, Window

Replacement, in Small Food Sales Buildings

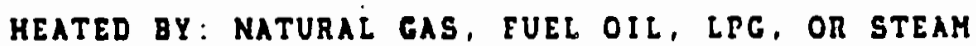

WEATHER ZONE

1

2

3

4

5

TOTAL

TOTAL ELOOR SPACE (MILLION SO. ET.)

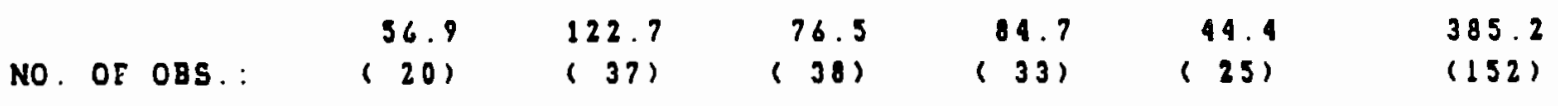

CUMULATIVE PERCENTACE COVERED BY MEASURE

$\begin{array}{lllllll}1972 & 0.0 & 0.0 & 0.0 & 0.0 & 0.0 & 0.0 \\ 1973 & 0.0 & 0.0 & 0.0 & 0.0 & 0.0 & 0.0 \\ 1974 & 5.0 & 0.0 & 0.0 & 0.0 & 0.0 & 0.7 \\ 1975 & 5.0 & 2.6 & 4.7 & 0.0 & 0.0 & 2.3 \\ 1976 & 5.0 & 2.5 & 4.7 & 0.0 & 0.0 & 2.5 \\ 1977 & 5.0 & 2.6 & 7.4 & 0.0 & 0.0 & 3.1 \\ 1978 & 5.0 & 6.6 & 9.9 & 0.0 & 3.7 & 5.2 \\ 1979 & 5.0 & 9.1 & 9.9 & 1.3 & 3.7 & 6.3\end{array}$

HEATED BY: ELECTRICITY

WEATHER ZONE

1

2

3

4

5

TOTAL

TOTAL ELOOR STACE (MILLION SO. FT.)

NO. OE ODS.:

$\begin{array}{rrrrrr}5.8 & 26.4 & 96.9 & 38.0 & 66.3 & 183.5 \\ (2) & (8) & (16) & (10) & (29) & (60)\end{array}$

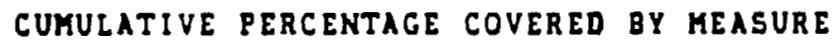

$\begin{array}{lrlllll}1972 & 0.0 & 0.0 & 0.0 & 0.0 & 0.0 & 0.0 \\ 1973 & 0.0 & 0.0 & 0.0 & 0.0 & 0.0 & 0.0 \\ 1979 & 0.0 & 0.0 & 0.0 & 0.0 & 0.0 & 0.0 \\ 1975 & 0.0 & 0.0 & 0.0 & 0.0 & 0.0 & 0.0 \\ 1976 & 0.0 & 0.0 & 0.0 & 0.0 & 0.0 & 0.0 \\ 1977 & 0.0 & 0.0 & 0.0 & 19.5 & 0.0 & 4.0 \\ 1979 & 43.1 & 0.0 & 2.5 & 19.5 & 0.0 & 6.0 \\ 1979 & 43.1 & 0.0 & 12.3 & 19.5 & 4.4 & 10.1\end{array}$


TABLE B.12. Historical Retrofit Activity, Caulking and Weatherstripping, in Large Food Sales Buildings

heATED By: NatURal Gas, fUEl OIL, LPG, OR STEAM

WEATHER ZONE

$\mathfrak{1}$

2

3

4

TOTAL

TOTAL FLOOR SPACE (MILLION SO. ET.)

NO. OF OBS.:

$\begin{array}{llll}223.2 & 400.2 & 152.0 & 83.6\end{array}$

(12)

76. 6

935.6

( 18$)$

(42)

$(16)$

$(7)$

(95)

CUKULATIVE PERCENTAGE COVERED BY MEASURE

$\begin{array}{lrrrrrr}1972 & 0.0 & 0.0 & 0.0 & 0.0 & 0.0 & 0.0 \\ 1973 & 0.0 & 0.0 & 0.0 & 7.8 & 0.0 & 0.7 \\ 1974 & 8.0 & 5.3 & 0.0 & 28.2 & 0.0 & 7.0 \\ 1975 & 8.0 & 10.1 & 0.0 & 28.2 & 0.0 & 9.1 \\ 1976 & 11.0 & 11.2 & 21.7 & 28.2 & 0.0 & 13.2 \\ 1977 & 17.6 & 17.1 & 21.7 & 32.1 & 0.0 & 17.8 \\ 1978 & 35.3 & 30.4 & 42.0 & 57.8 & 0.0 & 33.2 \\ 1979 & 72.1 & 47.1 & 44.9 & 57.8 & 18.6 & 51.3\end{array}$

HEATED BY: ELECTRICITY

WEATHER ZONE

1

2

3

4

5

TOTAL

TOTAL ELOOR SPACE (MILLION SO. FT.)
NO. OF OBS.:

$\begin{array}{rl}24.1 & 106.1 \\ (2) & (11)\end{array}$

92.5

75.5

57.2

355.4

CUMULATIVE PERCENTAGE COVERED BY MEASURE

1972
1973
1974
1975
1976
1977
1978
1979

0.0
0.0
0.0
0.0
0.0
66.6
100.0
100.0
0.0
19. 2
54.4

0.0

0.0

0.0

38.5

42.9

42.9

42.9

42.9

0.0

0.0

0.0

0.0

9. 7

9.7

9. 7

9. 7

0.

0.0

0.0

0.0

0.0

(33)

00.0

14. 7

14. 7

24.4

0.0

0.0

0.0

4. 2

7. 4

17.4

26.0

40.2 
TABLE B.13. Historical Retrofit Activity, Insulation, in Large Food Sales Buildings

HEATED BY: NATURAL GAS, EUEL OIL, LPG, OR STEAM

WEATHER ZONE

1

23

4

5

TOTAL

TOTAL ELOOR SPACE (MILLION SO. ET.)

NO. OE OBS.

$\begin{array}{rrrrrr}223.2 & 400.2 & 152.0 & 83.6 & 76.6 & 935.6 \\ (18) & (42) & (16) & (12) & (7) & (95)\end{array}$

CUMULATIVE PERCENTAGE COVERED BY MEASURE

$\begin{array}{lrrrrrr}1972 & 0.0 & 0.0 & 0.0 & 0.0 & 0.0 & 0.0 \\ 1973 & 0.0 & 0.0 & 0.0 & 0.0 & 0.0 & 0.0 \\ 1974 & 0.0 & 0.0 & 16.0 & 0.0 & 66.7 & 8.4 \\ 1975 & 0.0 & 4.6 & 16.0 & 0.0 & 66.7 & 10.6 \\ 1976 & 0.0 & 9.7 & 16.0 & 0.0 & 66.7 & 12.9 \\ 1977 & 5.6 & 19.0 & 16.0 & 3.9 & 66.7 & 18.7 \\ 1978 & 12.6 & 23.6 & 17.2 & 3.9 & 66.7 & 22.2 \\ 1979 & 29.4 & 30.0 & 17.2 & 3.9 & 66.7 & 27.2\end{array}$

HEATED BY: ELECTRICITY

WEATHER ZONE

1

2

3

4

5

TOTAL

TOTAL ELOOR SPACE (MILLION SO. FT.)

No. OF OBS.:

$\begin{array}{rrrrrr}24.1 & 106.1 & 92.5 & 75.5 & 57.2 & 355.4 \\ (2) & (11) & (7) & (5) & (8) & (33)\end{array}$

CUKULATIVE PERCENTAGE COVERED BY MEASURE

$\begin{array}{rr}0.0 & 0.0 \\ 0.0 & 0.0 \\ 0.0 & 0.0 \\ 0.0 & 0.0 \\ 0.0 & 0.0 \\ 66.6 & 0.0 \\ 66.6 & 14.2 \\ 66.6 & 16.6\end{array}$

0.0
0.0
0.0
12.2
12.2
12.2
12.2
13.6

0.0

0.0

0.0

0.0

0.0

0.0

4. 7

6.8

13.7

19.1

20.1 
TABLE B.14. Historical Retrofit Activity, Window

Replacement, in Large Food Sales Buildings

heATEd by: NatURAL Cas, EUEL OIL, LPG, OR STEAM

WEATHER ZONE

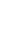

TOTAL ELOOR SPACE (MILLION SQ. TT.)

No. OF OBS.: $\quad \begin{array}{llllll}223.2 & 400.2 & 152.0 & 83.6 & 76.6 & 935.6 \\ (18) & (42) & (16) & (12) & (7) & (95)\end{array}$

CUMULATIVE PERCENTKGE COVERED BY MEASURE

$\begin{array}{lrrrrrr}1972 & 0.0 & 0.0 & 0.0 & 0.0 & 0.0 & 0.0 \\ 1973 & 0.0 & 0.0 & 0.0 & 0.0 & 0.0 & 0.0 \\ 1974 & 7.2 & 5.5 & 0.0 & 0.0 & 0.0 & 3.9 \\ 1975 & 7.2 & 8.4 & 0.0 & 0.0 & 0.0 & 5.2 \\ 1976 & 11.1 & 8.4 & 0.0 & 7.0 & 0.0 & 6.7 \\ 1977 & 17.5 & 8.4 & 0.0 & 7.0 & 0.0 & 7.9 \\ 1979 & 17.5 & 23.1 & 0.0 & 7.0 & 35.6 & 17.8 \\ 1979 & 29.2 & 25.7 & 6.4 & 7.0 & 35.6 & 22.5\end{array}$

WEATHER ZONE

HEATED BY: ELECTRICITY

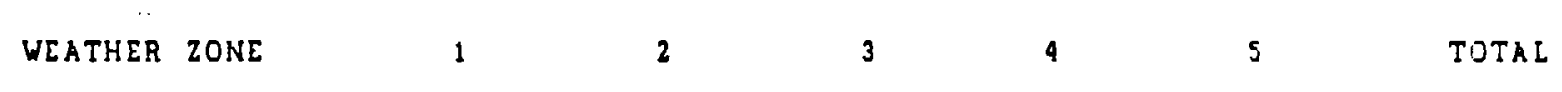

TOTAL FLOOR SPACE (MILLION SQ. FT.)

No. Of OBS.: $\quad \begin{array}{rrrrrr}24.1 & 106.1 & 92.5 & 75.5 & 57.2 & 355.4 \\ 2 & (11) & (7) & (5) & (8) & (33)\end{array}$

CUmulative percentage covercd ey measure

1972
1973
1974
1975
1976
1977
1978
1979

$\begin{array}{rrr}0.0 & 0.0 & 0.0 \\ 0.0 & 0.0 & 0.0 \\ 0.0 & 0.0 & 0.0 \\ 0.0 & 0.0 & 12.2 \\ 0.0 & 0.0 & 12.2 \\ 0.0 & 0.0 & 12.2 \\ 33.4 & 0.0 & 12.2 \\ 33.4 & 0.0 & 12.2\end{array}$

$\begin{array}{ll}0.0 & 0.0 \\ 0.0 & 0.0 \\ 0.0 & 0.0 \\ 0.0 & 0.0 \\ 0.0 & 0.0 \\ 0.0 & 0.0 \\ 0.0 & 0.0 \\ 0.0 & 0.0\end{array}$

0.0

0.0

0.0

4.4

4. 4

4. 4

7. 6

7. .́ 
TABLE B.15. Historical Retrofit Activity, Caulking and Weatherstripping, in Small Office Buildings

HEATED 8Y: NATURAL GAS, FUEL OIL, LPG, OR STEAM

WEATHER 2ONE

1

2

3

4

5

TOTAL

TOTAL FLOOR SPACE (MILLION SO. FT.)

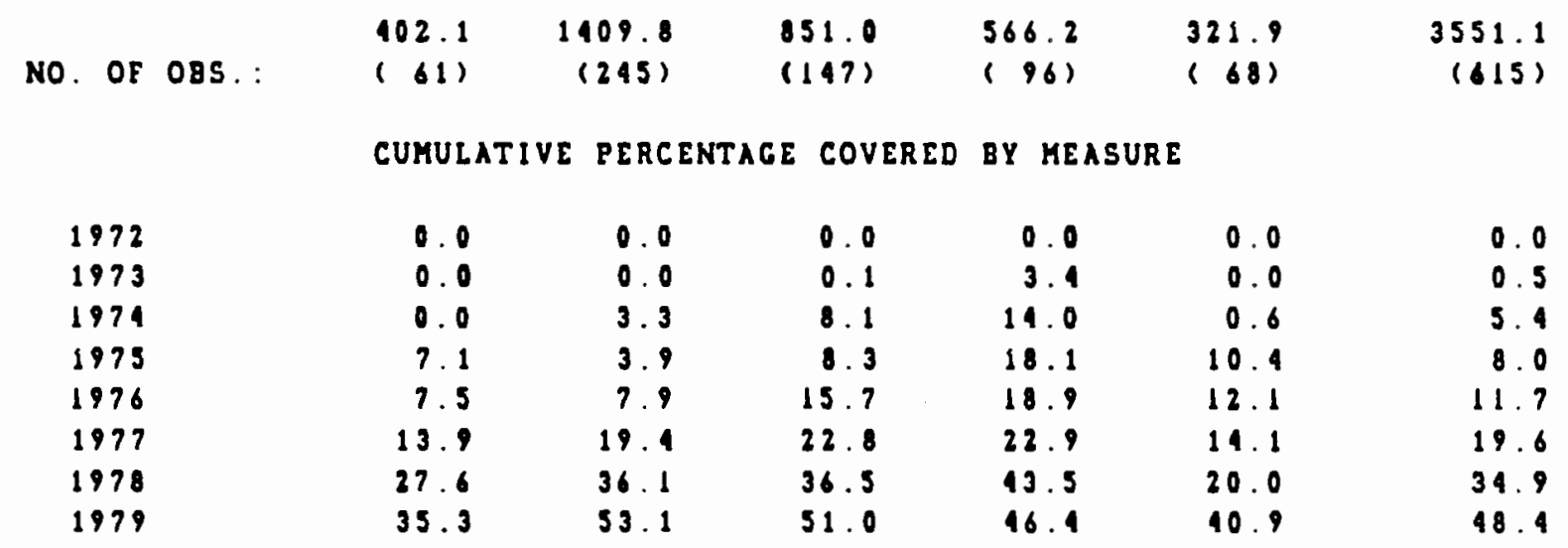

HEATED BY: ELECTRICITY

WEATHER ZONE

1

2

3

4

5

TOTAL

TOTAL FLOOR SPACE (MILLION SO. ET.)

NO. OF OBS.:

$\begin{array}{lllll}154.1 & 191.0 & 120.0 & 190.0 & 578.4\end{array}$

( 22)

(78)

(68)

(48) (95)

(311)

CUMULATIVE percentace COVEREd By meASURE

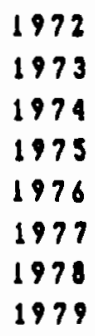

$\begin{array}{rr}0.0 & 0.0 \\ 0.0 & 2.2 \\ 0.0 & 2.6 \\ 0.0 & 6.5 \\ 0.0 & 10.8 \\ 5.2 & 12.9 \\ 10.7 & 35.0 \\ 19.8 & 50.3\end{array}$

0.0
0.0
3.3
1.5
6.9
7.6
15.1
27.0

0.0

0.0

0.0

2.3

3.3

3. 4

4.8

13.7

0.0
0.0
0.6
1.0
9.7
15.4
20.6
33.9

0. 0

0.5

1. 6

3. 3

7. 7

10.7

20.3

32.9 
TABLE B.16. Historical Retrofit Activity, Insulation, in Small Office Buildings

HEATED BY: NATURAL GAS, FUEL OIL, LPG, OR STEAM

WEATHER ZONE

1

2

3

4

5

TOTAL

TOTAL FLOOR SPACE (MILLION SQ. ET.)

NO. OF OBS.:

$\begin{array}{rrrrrr}402.1 & 1409.8 & 851.0 & 566.2 & 321.9 & 3551.1 \\ (61) & (245) & (147) & (96) & (68) & (615)\end{array}$

CUHULATIVE PERCENTAGE COVERED BY MEASURE

$\begin{array}{lrrrrrr}1972 & 0.2 & 0.0 & 0.0 & 0.0 & 1.4 & 0.1 \\ 1973 & 0.2 & 0.0 & 0.5 & 3.1 & 1.4 & 0.8 \\ 1974 & 0.2 & 2.9 & 2.1 & 5.9 & 3.0 & 2.9 \\ 1975 & 0.2 & 3.2 & 2.9 & 7.9 & 5.3 & 3.6 \\ 1976 & 1.7 & 1.7 & 1.6 & 7.1 & 11.6 & 5.2 \\ 1977 & 1.9 & 8.2 & 5.6 & 10.3 & 14.7 & 7.9 \\ 1978 & 11.3 & 19.3 & 8.7 & 10.9 & 17.8 & 14.3 \\ 1979 & 23.3 & 27.8 & 11.1 & 11.3 & 21.1 & 20.1\end{array}$

HEATED BY: ELECTRICITY

WEATHER 2ONE

1

2

3

4

5

TOTAL

TOTAL FLOOR SPACE (MILLION SO. ET.)

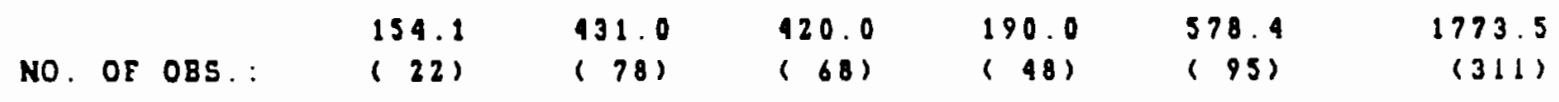

CUMULATIVE PERCENTAGE COVERED BY MEASURE

$\begin{array}{lrrrrrr}1972 & 0.0 & 0.0 & 0.0 & 0.0 & 0.9 & 0.3 \\ 1973 & 0.0 & 0.0 & 2.8 & 0.0 & 1.3 & 1.1 \\ 1979 & 0.0 & 0.2 & 6.5 & 0.0 & 2.5 & 2.4 \\ 1975 & 0.0 & 5.9 & 7.8 & 0.0 & 6.4 & 5.3 \\ 1976 & 5.9 & 7.7 & 8.0 & 0.0 & 6.8 & 6.4 \\ 1977 & 8.4 & 12.8 & 14.7 & 7.7 & 10.7 & 11.6 \\ 1978 & 8.4 & 22.2 & 21.4 & 12.5 & 18.1 & 18.4 \\ 1979 & 19.4 & 38.7 & 30.2 & 18.9 & 26.0 & 25.9\end{array}$


TABLE B.17. Historical Retrofit Activity, Window Replacement, in Small Office Buildings

HEATEd BY: MatURAL GAS, FUEL OIL, LPG, OR STEAM

WEATHER ZOKE

NO. OE OBS.: HEA

1

2

3

4

5

TOTAL

TOTAL FLOOR SPACE (MILLION SQ. FT.)

$\begin{array}{rrrrrr}102.1 & 1409.8 & (51.0 & 566.2 & 321.9 & 3551.1 \\ (61) & (215) & (197) & (96) & (68) & (615)\end{array}$

CUMULATIVE PERCENTAGE COVERED BY MEASURE

$\begin{array}{lrrrrrr}1972 & 0.0 & 0.1 & 3.2 & 1.0 & 0.0 & 1.0 \\ 1973 & 0.0 & 0.7 & 3.1 & 1.0 & 0.9 & 1.2 \\ 1979 & 0.0 & 5.2 & 3.1 & 1.0 & 2.8 & 3.3 \\ 1975 & 5.6 & 6.5 & 3.1 & 1.0 & 10.6 & 5.2 \\ 1976 & 5.6 & 9.3 & 1.8 & 1.0 & 12.6 & 6.8 \\ 1977 & 6.6 & 13.1 & 5.5 & 2.7 & 15.9 & 9.2 \\ 1978 & 8.2 & 19.6 & 10.1 & 3.0 & 19.4 & 13.4 \\ 1979 & 10.3 & 27.2 & 14.7 & 9.6 & 26.5 & 19.4\end{array}$

HEATED BY: ELECTRICITY

WEATHER ZONE

1

2

3

4

5

TOTAL

TOTAL ELOOR SPACE (MILLION SQ. ET.)

\begin{tabular}{|c|c|c|c|c|c|}
\hline & 154.1 & 431.0 & 420.0 & 190.0 & 1773.5 \\
\hline 0. OE OBS. & $(22)$ & $(78)$ & $(68)$ & $(48)$ & $(311)$ \\
\hline
\end{tabular}

CUMUlative PERCENTAge COVERED By measure

$\begin{array}{lrrrrrr}1972 & 0.0 & 3.5 & 0.0 & 0.0 & 11.1 & 1.5 \\ 1973 & 0.0 & 3.5 & 0.0 & 3.2 & 11.4 & 9.9 \\ 1974 & 2.7 & 10.5 & 1.7 & 7.6 & 11.4 & 7.7 \\ 1975 & 2.7 & 10.5 & 1.7 & 9.6 & 11.4 & 7.9 \\ 1976 & 2.7 & 13.9 & 2.9 & 9.6 & 17.5 & 11.0 \\ 1979 & 2.7 & 13.9 & 7.9 & 15.3 & 17.5 & 12.8 \\ 1978 & 2.7 & 22.0 & 10.5 & 21.4 & 25.1 & 18.5 \\ 1979 & 4.1 & 22.0 & 16.5 & 27.3 & 39.5 & 23.8\end{array}$


TABLE B.18. Historical Retrofit Activity, Caulking and Weatherstripping, in Large Office Buildings

HEATED BY: NATURAL GAS, FUEL OIL, LPG, OR STEAK

WEATHER ZONE

1

2

3

4

s

TOTAL

TOTAL FLOOR SPACE (MILLION SO. FT.)

No. OF OBS.:

$\begin{array}{rrrrrr}141.1 & 659.4 & 663.2 & 652.5 & 164.2 & 2280.4 \\ (21) & (66) & (82) & (37) & (21) & (225)\end{array}$

CUMULATIVE PERCENTAGE COVERED BY MEASURE

$\begin{array}{lrrrrrr}1972 & 0.0 & 0.0 & 0.0 & 0.0 & 0.0 & 0.0 \\ 1973 & 0.0 & 0.0 & 2.9 & 0.0 & 2.0 & 1.1 \\ 1979 & 0.0 & 0.8 & 6.5 & 0.0 & 2.0 & 2.5 \\ 1975 & 1.1 & 2.7 & 16.0 & 0.0 & 2.0 & 6.2 \\ 1976 & 1.9 & 7.5 & 21.6 & 0.0 & 1.1 & 9.7 \\ 1977 & 21.6 & 16.0 & 10.4 & 3.6 & 4.4 & 20.1 \\ 1978 & 75.0 & 29.7 & 49.1 & 60.1 & 5.4 & 45.1 \\ 1979 & 11.8 & 67.9 & 71.3 & 71.8 & 13.4 & 66.9\end{array}$

HEATED BY: ELECTRICITY

WEATHER ZONE

1

2

3

4

3

TOTAL

TOTAL FLOOR SPACE (MILLION SO. FT.)

No. OF OBS.:

$\begin{array}{rrrrrr}70.3 & 71.6 & 229.0 & (18.8 & 81.0 & 570.7 \\ (5) & (18) & (25) & (19) & (11) & (78)\end{array}$

CUMULATIVE PERCENTAGE COVERED BY MEASURE

$\begin{array}{lrrrrrr}1972 & 0.0 & 0.0 & 0.0 & 0.0 & 0.0 & 0.0 \\ 1973 & 0.0 & 0.0 & 0.0 & 0.0 & 0.0 & 0.0 \\ 1974 & 0.0 & 5.8 & 0.0 & 0.0 & 0.0 & 0.8 \\ 1975 & 1.8 & 5.8 & 0.0 & 0.0 & 0.0 & 1.4 \\ 1976 & 10.2 & 10.2 & 0.0 & 2.9 & 7.9 & 4.2 \\ 1979 & 10.2 & 11.5 & 7.3 & 15.3 & 18.2 & 11.2 \\ 1978 & 64.2 & 30.4 & 16.8 & 17.8 & 18.2 & 25.3 \\ 1979 & 64.2 & 69.2 & 61.2 & 33.6 & 76.3 & 59.0\end{array}$


TABLE B.19. Historical Retrofit Activity, Insulation in Large Office Buildings

HEATED BY: NaTURAL GAS, EUEL OIL, LPG, OR STEAK

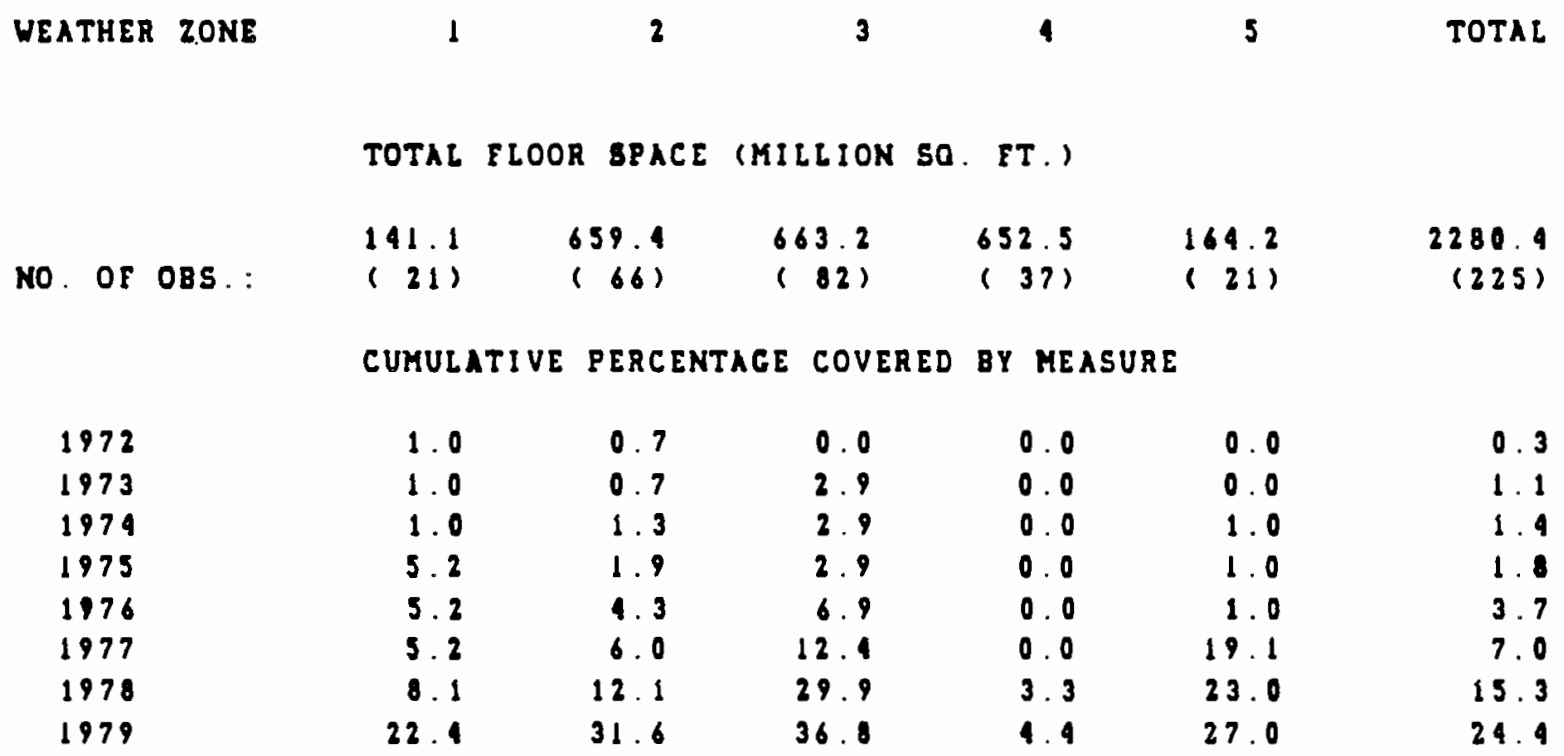

HEATED BY: ELECTRICITY

WEATHER ZONE

2

15

TOTAL

TOTAL FLOOR SPACE (MILLION SQ. FT.)

$\begin{array}{lcccccr}\text { NO. OE 085.: } & 70.3 & 71.6 & 229.0 & 118.8 & 81.0 & 570.7 \\ & (5) & (18) & (25) & (19) & (11) & (78) \\ 1972 & \text { CUMULATIVE } & \text { PERCENTAGE COVERED } & \text { BY MEASURE } & \\ 1973 & 0.0 & 0.0 & 0.0 & 0.0 & 0.0 & 0.0 \\ 1974 & 0.0 & 0.0 & 0.0 & 0.0 & 0.0 & 0.0 \\ 1975 & 0.0 & 0.0 & 0.0 & 0.0 & 0.0 & 0.0 \\ 1976 & 1.8 & 1.1 & 0.0 & 0.0 & 7.3 & 1.8 \\ 1977 & 1.8 & 7.2 & 0.0 & 1.6 & 7.3 & 3.5 \\ 1978 & 1.8 & 7.2 & 11.5 & 1.6 & 7.3 & 8.1 \\ 1979 & 10.2 & 20.3 & 11.5 & 8.6 & 7.3 & 11.2 \\ & 10.2 & 38.0 & 13.1 & 11.1 & 7.3 & 14.6\end{array}$


TABLE B.20. Historical Retrofit Activity, Window Replacement, in Assembly Buildings

hEATED BY: NATURAL GAS, FUEL OIL, LPG, OR STEAM

UEATHER ZONE

1

2

3

4

5

TOTAL

TOTAL FLOOR SPACE (MILLION SQ. ET.)

\begin{tabular}{|c|c|c|c|c|c|}
\hline & 14 & 659.4 & 663.2 & 652.5 & 164.2 \\
\hline BS.: & $(21)$ & $(66)$ & $(82)$ & $(37)$ & $(21)$ \\
\hline
\end{tabular}

CUMULATIVE PERCENTAGE COVERED BY MEASURE

$\begin{array}{lrrrrrr}1972 & 0.0 & 8.2 & 0.0 & 0.0 & 0.0 & 2.2 \\ 1973 & 1.0 & 8.9 & 0.0 & 0.0 & 0.0 & 2.3 \\ 1974 & 0.0 & 1.1 & 0.4 & 0.0 & 0.0 & 2.5 \\ 1975 & 3.9 & 12.6 & 1.0 & 0.0 & 0.0 & 3.9 \\ 1976 & 5.8 & 12.6 & 1.4 & 0.0 & 0.0 & 4.1 \\ 1977 & 7.1 & 13.4 & 6.1 & 3.3 & 0.0 & 6.9 \\ 1978 & 14.7 & 24.7 & 7.1 & 8.1 & 0.0 & 12.1 \\ 1979 & 18.6 & 32.8 & 26.5 & 17.6 & 4.3 & 23.7\end{array}$

WEATHER ZONE

HEATED BY: ELECTRICITY

$\begin{array}{llllll}1 & 2 & 3 & 4 & 5 & \text { TOTAL }\end{array}$

TOTAL FLOOR SPACE (MILLION SO. ET.)

\begin{tabular}{|c|c|c|c|c|c|c|}
\hline & 70.3 & 71.6 & 229.0 & 118.8 & 81.0 & 570 \\
\hline No. OE & $(5)$ & $(18)$ & $(25)$ & $(19)$ & $(4)$ & \\
\hline
\end{tabular}

CUmulative percentace covered by measure

$\begin{array}{lrrrrrr}1972 & 0.0 & 0.0 & 0.0 & 0.0 & 0.0 & 0.0 \\ 1973 & 0.0 & 0.0 & 0.0 & 0.0 & 0.0 & 0.0 \\ 1974 & 0.0 & 0.0 & 0.0 & 0.0 & 0.0 & 0.0 \\ 1975 & 0.0 & 0.0 & 0.0 & 0.0 & 0.0 & 0.0 \\ 1976 & 0.0 & 0.0 & 0.0 & 3.8 & 0.0 & 0.8 \\ 1977 & 0.0 & 0.0 & 0.0 & 3.8 & 5.9 & 1.7 \\ 1978 & 0.0 & 10.0 & 0.0 & 3.8 & 5.9 & 3.1 \\ 1979 & 29.5 & 14.5 & 2.7 & 6.7 & 16.0 & 10.2\end{array}$


TABLE B.21. Historical Retrofit Activity, Caulking and

Weatherstripping, in Small Retail/Service Buildings

HEATED BY: NATURAL GAS, EUEL OIL, LPG, OR STEAM

WEATHER ZONE

1

2

3

4

s

TOTAL

TOTAL ELOOR SEACE (MILLION SO. ET.)

\begin{tabular}{|c|c|c|c|c|c|}
\hline & 481.9 & 1126.1 & 131.6 & 207.6 & 395.9 \\
\hline$O E$ & $(62)$ & $(153)$ & $(128)$ & $(84)$ & $(66)$ \\
\hline
\end{tabular}

CUMULATIVE PERCENTAGE COVERED BY MEASURE

$\begin{array}{lrrrrrr}1972 & 0.0 & 0.0 & 0.0 & 0.0 & 0.0 & 0.0 \\ 1973 & 1.7 & 0.0 & 0.0 & 0.0 & 0.0 & 0.2 \\ 1974 & 1.7 & 0.6 & 3.2 & 0.2 & 1.7 & 1.4 \\ 1975 & 11.1 & 3.2 & 3.2 & 0.2 & 2.8 & 3.6 \\ 1976 & 18.3 & 14.9 & 8.7 & 3.2 & 2.8 & 10.2 \\ 1977 & 25.1 & 20.3 & 14.6 & 5.7 & 7.6 & 15.3 \\ 1978 & 12.5 & 36.3 & 31.1 & 17.0 & 16.2 & 30.5 \\ 1979 & 58.9 & 54.0 & 40.5 & 21.5 & 22.0 & 41.4\end{array}$

VEATHER ZONE

HEATED BY: ELECTRICITY

1

2

3

4

5

TOTAL

TOTAL FLOOR SPACE (MILLION SQ. ET.)

\begin{tabular}{|c|c|c|c|c|c|}
\hline & 22.3 & 124.9 & 250.3 & 219.7 & 336.5 \\
\hline & $(7)$ & $(17)$ & $(36)$ & $(30)$ & $(56)$ \\
\hline
\end{tabular}

CUMULATIVE PERCENTAGE COVERED BY kEASURE

$\begin{array}{lrrrrrr}1972 & 0.0 & 0.0 & 0.0 & 0.0 & 0.0 & 0.0 \\ 1973 & 0.0 & 0.0 & 0.0 & 0.0 & 0.1 & 0.0 \\ 1974 & 6.8 & 0.0 & 0.0 & 0.0 & 0.4 & 0.3 \\ 1975 & 6.8 & 10.1 & 0.0 & 0.0 & 2.3 & 2.2 \\ 1976 & 6.8 & 12.5 & 0.0 & 1.0 & 7.6 & 1.7 \\ 1977 & 6.8 & 12.5 & 0.5 & 3.9 & 10.1 & 6.4 \\ 1978 & 6.8 & 21.1 & 10.2 & 5.7 & 21.7 & 14.6 \\ 1979 & 35.1 & 11.7 & 19.6 & 13.0 & 30.7 & 25.2\end{array}$


TABLE B.22. Historical Retrofit Activity, Insulation in Small Retail/Service Buildings

HEATED BY: NATURAL GAS, FUEL OIL, LPG, OR STEAK

WEATHER ZONE

1

2

3

s

TOTAL

TOTAL ELOOR SPACE (MILLION SO. ET.)

\begin{tabular}{|c|c|c|c|c|c|c|}
\hline & 18 & 1126.1 & 931.6 & 707.6 & 395.9 & 3643. \\
\hline 085 & $\left(\begin{array}{ll}(62\end{array}\right)$ & $(153)$ & $(128)$ & $(81)$ & $(66)$ & 1489 \\
\hline
\end{tabular}

CUMULATIVE PERCENTAGE COVERED BY MEASURE

$\begin{array}{lrrrrrr}1972 & 0.0 & 0.0 & 0.0 & 2.3 & 0.0 & 0.5 \\ 1973 & 0.0 & 0.0 & 0.0 & 2.3 & 0.0 & 0.5 \\ 1974 & 5.2 & 0.3 & 0.8 & 3.0 & 2.5 & 1.8 \\ 1975 & 11.2 & 3.3 & 1.9 & 4.8 & 9.1 & 4.9 \\ 1976 & 15.5 & 1.2 & 0.2 & 1.8 & 11.1 & 7.6 \\ 1977 & 23.4 & 7.1 & 12.2 & 5.3 & 11.1 & 10.8 \\ 1978 & 35.5 & 17.4 & 24.2 & 7.2 & 12.7 & 19.0 \\ 1979 & 36.5 & 30.4 & 28.5 & 10.1 & 15.5 & 25.2\end{array}$

HEATED BY: ELECTRICITY

WEATHER ZONE

1

2

3

4

TOTAL

TOTAL ELOOR SPACE (MILLION SO. ET.)

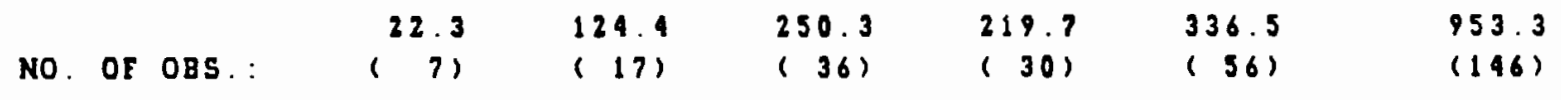

CUMULATIVE PERCENTAGE COVERED BY MEASURE

$\begin{array}{lrrrrrr}1972 & 0.0 & 0.0 & 0.0 & 0.0 & 0.0 & 0.0 \\ 1973 & 0.0 & 0.0 & 0.0 & 0.0 & 2.3 & 0.8 \\ 1974 & 6.8 & 0.0 & 0.0 & 0.0 & 2.3 & 1.0 \\ 1975 & 6.8 & 0.0 & 0.0 & 0.0 & 2.3 & 1.0 \\ 1976 & 6.8 & 0.0 & 0.0 & 0.0 & 3.4 & 1.4 \\ 1977 & 6.8 & 0.0 & 0.5 & 2.0 & 5.3 & 2.6 \\ 1978 & 6.8 & 30.7 & 0.8 & 2.1 & 10.6 & 8.6 \\ 1979 & 82.4 & 49.3 & 8.5 & 2.8 & 12.0 & 15.5\end{array}$


TABLE B.23. Historical Retrofit Activity, Window

Replacement, in Sma11 Retail/Service Buildings

hEATED BY: NATURAL GAS, FUEL OIL, LPG, OR STEAM

WEATHER ZONE

1

2

3

5

TOTAL

TOTAL FLOOR SPACE (HILLION SQ. FT.)

\begin{tabular}{|c|c|c|c|c|c|}
\hline & 481.9 & 1126.1 & 931.6 & 707.6 & 395.9 \\
\hline & 62) & $(153)$ & $(128)$ & $(84)$ & $(66)$ \\
\hline
\end{tabular}

CUMULATIVE PERCENTAGE COVERED BY MEASURE

$\begin{array}{lrrrrrr}1972 & 1.4 & 1.5 & 0.0 & 0.0 & 0.0 & 0.6 \\ 1973 & 3.9 & 3.2 & 0.0 & 0.0 & 0.0 & 1.7 \\ 1974 & 9.9 & 3.2 & 0.0 & 2.3 & 0.0 & 2.8 \\ 1972 & 10.2 & 3.2 & 0.9 & 2.5 & 0.0 & 3.1 \\ 1976 & 14.5 & 4.7 & 0.9 & 7.1 & 0.8 & 5.1 \\ 1977 & 17.1 & 8.1 & 3.0 & 9.9 & 0.8 & 7.6 \\ 1978 & 17.1 & 11.8 & 1.7 & 12.3 & 0.8 & 9.5 \\ 1979 & 20.8 & 13.5 & 5.3 & 12.4 & 6.5 & 11.4\end{array}$

HEATED BY: ELECTRICITY

WEATHER 2ONE

1

2

3

4

5

TOTAL

TOTAL FLOOR SPACE (MILLION SO. FT.)

\begin{tabular}{|c|c|c|c|c|c|c|}
\hline & 22.3 & 124.4 & 250.3 & 219.7 & 336.5 & 953. \\
\hline OF OBS. & $(7)$ & $(17)$ & $(36)$ & $(30)$ & $(56)$ & $(196)$ \\
\hline
\end{tabular}

CUMULATIVE PERCENTAGE COVERED GY MEASURE

$\begin{array}{lrllllr}1972 & 0.0 & 0.0 & 0.0 & 0.0 & 0.0 & 0.0 \\ 1973 & 0.0 & 0.0 & 0.0 & 8.3 & 0.0 & 0.1 \\ 1974 & 0.0 & 0.0 & 0.0 & 8.3 & 3.0 & 1.5 \\ 1975 & 0.0 & 0.0 & 0.0 & 1.3 & 3.0 & 1.5 \\ 1976 & 0.0 & 0.0 & 0.0 & 8.3 & 1.9 & 2.2 \\ 1977 & 0.0 & 0.1 & 0.8 & 8.3 & 1.9 & 2.5 \\ 1978 & 0.0 & 0.1 & 1.3 & 8.3 & 14.4 & 7.1 \\ 1979 & 28.3 & 6.7 & 1.3 & 8.3 & 16.2 & 10.3\end{array}$


TABLE B.24. Historical Retrofit Activity, Caulking and Weatherstripping, in Large Retail/Service Buildings

MEATED BY: NATURAL GAS, FUEL OIL, LPG, OR STEAM

WEATHER ZONE

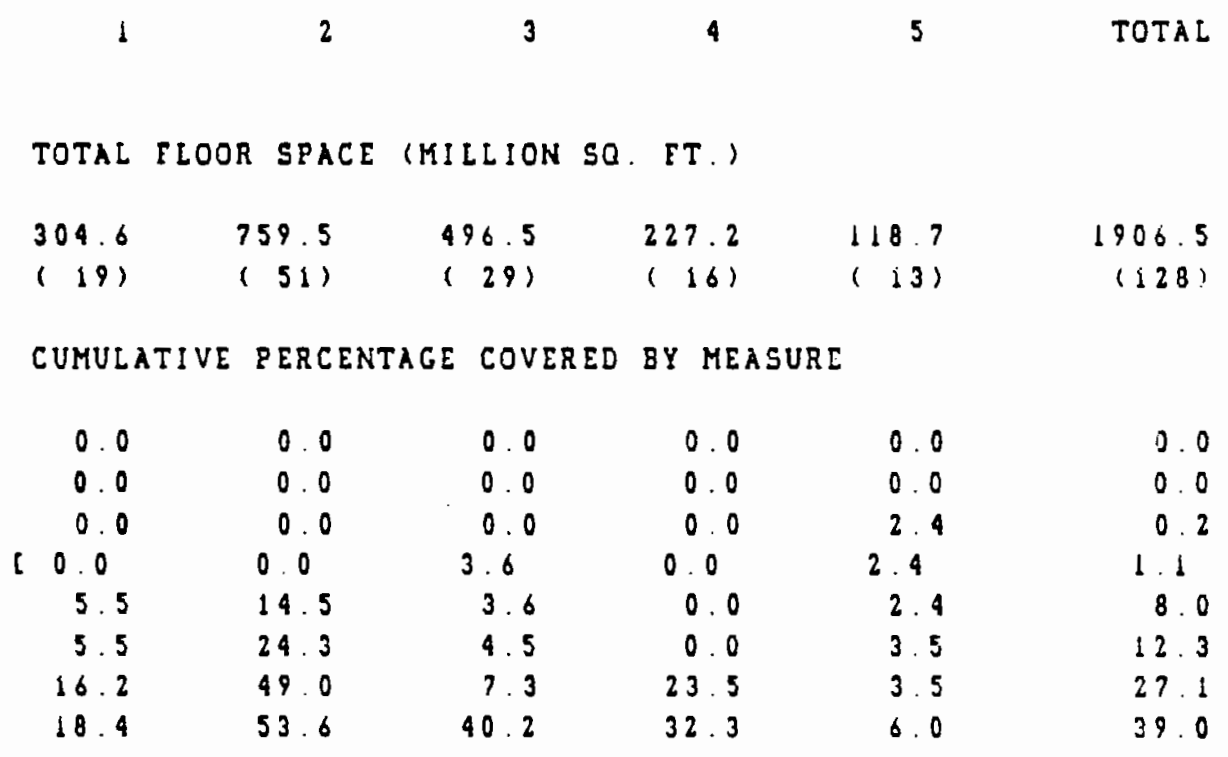

HEATED BY: ELECTRICITY

WEATHER ZONE

1

2

3

4

5

TOTAL

TOTAL FLOOR SPACE (HILLION SO. ET.)

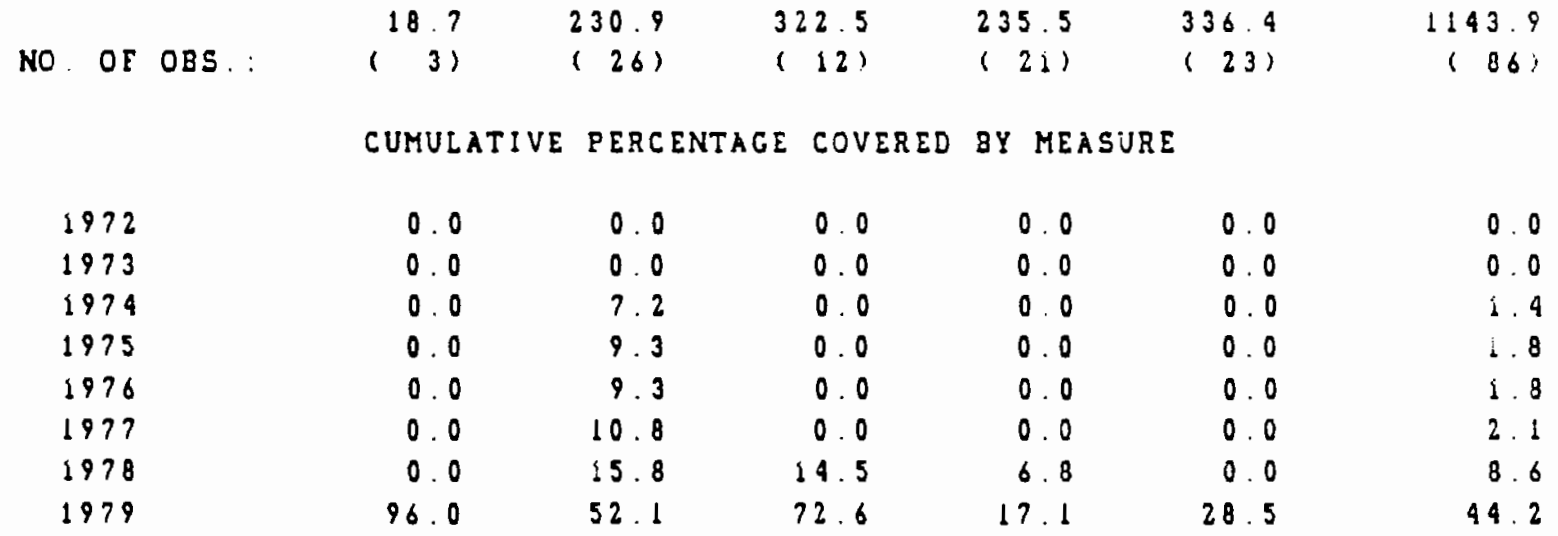


TABLE B.25. Historical Retrofit Activity, Insulation, in Large Retail/Service Buildings

HEATED BY: NATURAL GAS, TUEL OIL, LPG, OR STEAM

WEATHER ZONE

1

2

3

4

5

TOTAL

TOTAL TLOOR SPACE (MILLION SO. FT.)

\begin{tabular}{|c|c|c|c|c|c|c|}
\hline \multirow{3}{*}{ NO. OF OBS.: } & 304.6 & 759.5 & 96.5 & 227.2 & 118.7 & 1906.5 \\
\hline & $(19)$ & $(51)$ & 291 & $(16)$ & $(13)$ & $(128)$ \\
\hline & CUMULATIVE & PERCENTAGE & COVERED & BY MEASURE & & \\
\hline 1972 & 0.0 & 0.0 & 0.0 & 0.0 & 0.0 & 0.0 \\
\hline 1973 & 0.0 & 0.0 & 0.0 & 0.0 & 0.0 & 0.0 \\
\hline 1974 & 4.4 & 0.0 & 0.0 & 0.0 & 2.4 & 0.9 \\
\hline 1975 & 4.9 & 0.0 & 0.0 & 0.0 & 2.4 & 0.9 \\
\hline 1976 & 4. 4 & 1.3 & 0.0 & 0.0 & 33.5 & 3.5 \\
\hline 1977 & 6.2 & 5.0 & 6.1 & 0.0 & 33,1 & 7.0 \\
\hline 1978 & 8.4 & 21.8 & 6.1 & 0.0 & 33.1 & 19.4 \\
\hline 1979 & 13.7 & 28.4 & 9.5 & 26.6 & 58.1 & 22.7 \\
\hline
\end{tabular}

HEATED BY: ELECTRICITY

WEATHER ZONE

1

2

3

4

5

TOTAL

TOTAL FLOOR SPACE (HILLION SO. FT.)

No. OF OBS.:

$\begin{array}{llll}18.7 & 230.9 & 322.5 & 235.5\end{array}$

336.4

(12) (21)

( 23)

1143.9

(86)

CUMULATIVE PERCENTAGE COVERED By MEASURE

$$
\begin{aligned}
& 1972 \\
& 1973 \\
& 1974 \\
& 1975 \\
& 1976 \\
& 1977 \\
& 1978 \\
& 1979
\end{aligned}
$$

0.0
0.0
0.0
0.0
0.0
0.0
4.0
4.0

0.0
0.0
0.0
0.0
0.0
0.6
11.5
30.6

0.0

0.0

0.0

0.0

0.0

0.0

0.0

8.?
3. 2
3. 2
3. 2
3. 2
3. 2
5. 7
5. 7
5. $?$

0.0

0.0

0.0

0.0

0.0

1.?

2. 5

25.1

0.6
0.6
0.6
0.6
0.6
1.8
4.3
17.1 
TABLE B.26. Historical Retrofit Activity Window Replacement, in Large Retail/Service Buildings

HEATED BY: NatURAL Gas, EUEL OIL, LPG, OR STEAH

WEATHER ZONE

1

23

4

5

TOTAL

TOTAL FLOOR SPACE (MILLION SQ. FT.)

NO. OE OES.:

$\begin{array}{llllll}304.6 & 759.5 & 496.5 & 227.2 & 118.7 & 1906.5 \\ (19) & (51) & (29) & (16) & (13) & (128)\end{array}$

CUMULATIVE PERCENTAGE COVERED BY MEASURE

$\begin{array}{lrrrrrr}1972 & 0.0 & 0.0 & 0.0 & 0.0 & 0.0 & 0.0 \\ 1973 & 0.0 & 3.2 & 0.9 & 0.0 & 0.0 & 1.4 \\ 1979 & 0.0 & 4.7 & 0.9 & 0.0 & 0.0 & 1.9 \\ 1975 & 0.0 & 4.7 & 0.9 & 0.0 & 0.0 & 1.9 \\ 1976 & 0.0 & 10.1 & 1.2 & 0.0 & 0.0 & 3.7 \\ 1977 & 0.0 & 10.6 & 1.2 & 0.0 & 0.0 & 3.9 \\ 1978 & 0.0 & 10.6 & 2.9 & 14.4 & 10.3 & 7.7 \\ 1979 & 0.0 & 12.0 & 3.5 & 18.3 & 10.3 & 9.1\end{array}$

WEATHER ZONE

HEATED BY: ELECTRICITY

1

2

3

4

5

TOTAL

TOTAL TLOOR SPACE (MILLION SO. FT.)

NO. Or OBS.:

$\begin{array}{llll}18.7 & 230.9 & 322.5 & 235.5\end{array}$

(12)

(21)

336.4

1143.9

(86)

CUMUlative PERCENTAGE COVERED gY MEASURE

$\begin{array}{lllllll}1972 & 0.0 & 0.0 & 0.0 & 3.2 & 0.0 & 0.6 \\ 1973 & 0.0 & 0.0 & 0.0 & 3.2 & 0.0 & 0.6 \\ 1979 & 0.0 & 0.0 & 0.0 & 3.2 & 0.0 & 0.6 \\ 1975 & 0.0 & 0.0 & 0.0 & 3.2 & 0.0 & 0.6 \\ 1976 & 0.0 & 0.0 & 0.0 & 3.2 & 0.0 & 0.6 \\ 1977 & 0.0 & 2.1 & 0.0 & 3.2 & 0.0 & 1.1 \\ 1978 & 0.0 & 14.6 & 0.0 & 7.1 & 0.0 & 4.4 \\ 1979 & 0.0 & 16.0 & 0.0 & 7.1 & 2.5 & 5.4\end{array}$


TABLE B.27. Specifications for Prototype Buildings

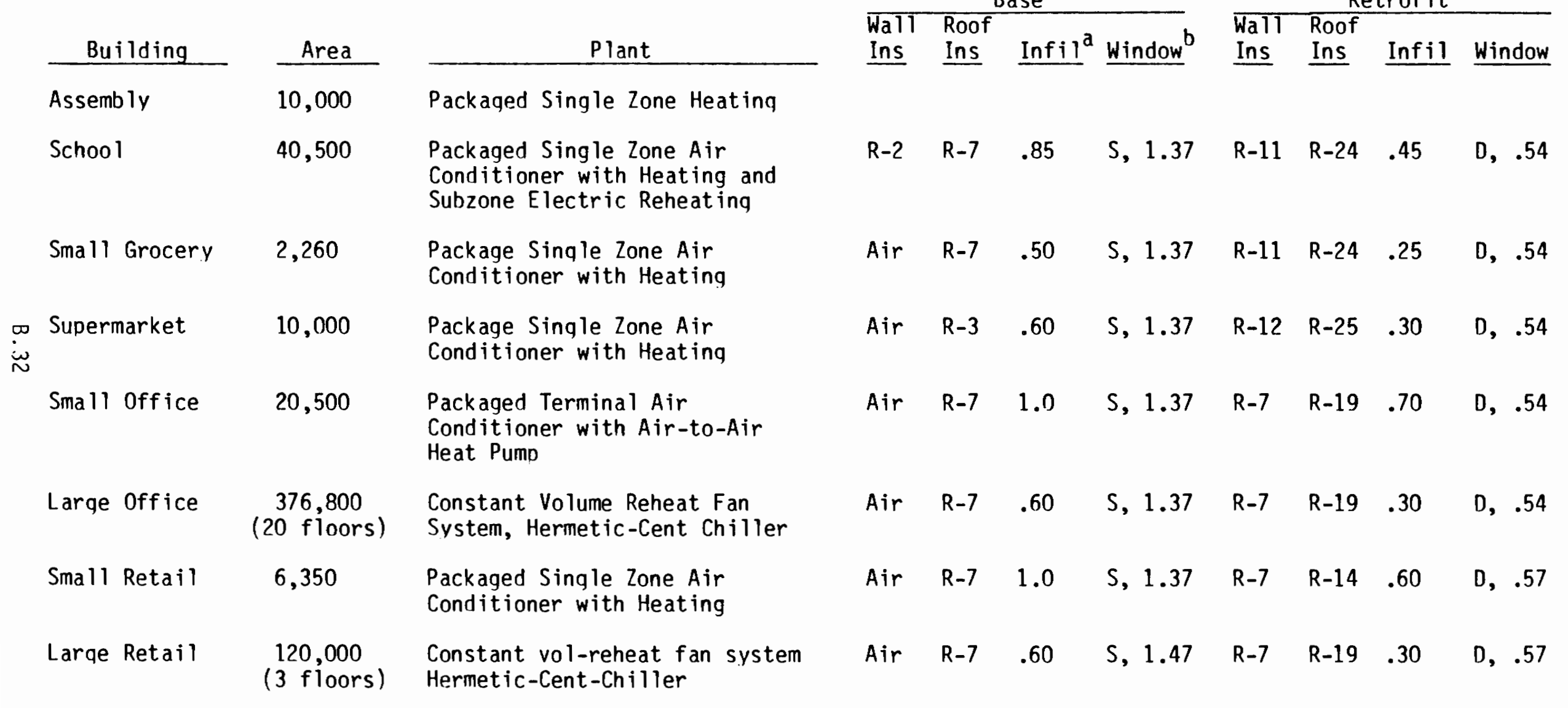

a Infil = Infiltration rate, air changes per hour.

b $S, D=$ Single nane, double pane, respectively. Accompanying value is conductivity of glass, Btu/sq.ft. -hr. ${ }^{0} \mathrm{~F}$. 
throughout the construction industry, this approach may reasonably reflect actual construction/retrofit practices.

Pre-embargo specifications for ceiling and roof insulation were taken from the recommended values supplied in ASHRAE Fundamentals, 1973. For the retrofits after 1974, buildings were assumed to meet the 90A-1980 standard. For roof insulation, prior work. on commercial buildings for the Northwest Power Planning Council suggested that building owners actually exceeded recommended $R$ values when installing ceiling insulation in an existing building. For some building types, as a result, the ceiling values were increased up to 20 percent beyond the recommended values. In the wall, the amount of insulation is usually limited by the available space and so the (unadjusted) standard value was used.

Parameterization of caulking and weatherstripping activity was done in terms of air changes per hour. ASHRAE provides a range of recommended infiltration rates for particular building types; these ranges have changed little since the early 1970s. For the modeling work in this study, it was assumed the infiltration rate in a pre-embargo building was near the middle of the ASHRAE range. Weatherstripping and caulking were assumed to reduce the rate to the lower limit of the range.

Finally, with respect to windows, the survey simply asks whether tinted, reflective, insulated, or thermal glass has been installed. Perhaps, the most economical of retrofit measures affecting windows is the installation of a second pane of glass, which reduces thermal conductivity. Accordingly, for this study, the assumption was made that a positive response to the window treatment/replacement question implied the equivalent of an additional window pane. As Table B.27 shows, this basically reduced the thermal conductivity by roughly 60 percent for most building types.

These assumptions form the basis of input to the DOE-2 model. Four runs were made for each building type and weather zone: 1) base, (2) caulking, (3) insulation, and (4) treated windows (tinted, reflective, insulated, or thermal pane). Runs (2), (3), and (4) were all run as deviations from the base specifications. Percentage changes in energy consumption were then calculated for each retrofit activity for each building type. 
For this study potential interaction effects among retrofit actions were ignored. That is, the percentage reduction in energy use due to say, caulking and insulation, were calculated as simply the sum of the percentage changes of the two measures considered separately. This decision was made for several reasons. First, in test simulations, the additivity assumption holds reasonably well for these types of relatively small changes affecting only the building shell. Second, the complexity of the analysis would have increased substantially; instead of three runs for each building type, eight would have been required to cover all combinations of various retrofit options. Moreover, in constructing the aggregate estimates, each sample building would have had to have been separately analyzed. Under the additivity assumption, the computation reduces to the total percentage of square feet of each building type covered by each measure. Finally, the added precision for this aspect of the study seemed disproportionate relative to the uncertainties regarding the specification of the prototype building characteristics assumed and the retrofit actions.

The DOE-2 model requires a complete weather profile--more than simply annual heating and cooling degree days. Accordingly, a "representative" city was chosen for each of the five major weather zones identified in the NBECS survey. All cities were in the western U.S. since a complete set of weather tapes were not readily available for the study. The cities chosen are shown in Table B.28.

Table B.29 shows the results of the DOE-2 simulations for assembly buildings. Based on the assumptions in Table B.1, the percentage changes in energy consumption for this building type are relatively modest; except for one observation (caulking in zone 4), all percentage changes are less than 10 percent. The weather zones are ordered from highest to lowest heating load and, vice versa for cooling. Portland represents the most moderate weather zone by displaying the minimum energy consumption per square foot (198.8 KBtu) for buildings heated with fossil fuels or steam. As expected, the percentage changes from additional insulation are greater for cities with higher heating loads. This is generally true for caulking and treated windows. In all cases, the percentage reductions are greater for buildings heated by electricity than for buildings heated directly by fossil fuels. This result stems largely from 
TABLE B.28. Cities Used for Weather Zone Sensitivity Analysis

\begin{tabular}{|c|c|c|c|c|}
\hline Weather Zone & $\begin{array}{l}\mathrm{COD} / \mathrm{HOD}^{*} \\
\text { Range }\end{array}$ & City & $\cos ^{\&}$ & $\underline{H D O}^{\&}$ \\
\hline 1 & $\begin{array}{l}<2000 \mathrm{CDO} \\
>7000 \mathrm{HDO}\end{array}$ & Casper, WY & 458 & 7555 \\
\hline 2 & $\begin{array}{l}<2000 \mathrm{COD} \\
>5500-7000 \mathrm{HOD}\end{array}$ & Denver & 625 & 6016 \\
\hline 3 & $\begin{array}{l}<2000 \mathrm{CDD} \\
2000-5500 \mathrm{HDD}\end{array}$ & Portiand, Ore. & 300 & 4792 \\
\hline 4 & $\begin{array}{l}<2000 \text { CDD } \\
2000-4000 \mathrm{HDD}\end{array}$ & Las Vegas & 2946 & 2601 \\
\hline 5 & $\begin{array}{l}<2000 \text { CDD } \\
0-2000 \text { HDD }\end{array}$ & Phoen ix & 3503 & 1552 \\
\hline
\end{tabular}

$\star \mathrm{CDD}, \mathrm{HDD}=$ Cooling and Heating Degree Days, Base $65^{\circ} \mathrm{F}$.

\& 30 year average 1941-70. Source: Local Climatological Data, Annual Summaries for 1979. U.S. Department of Commerce, National Oceanic and Atmospheric Administration. 
TABLE B.29. Simulated Energy Reductions for Retrofit Measures:

ASSEMBLY BUILDING

Zone 1 Zone 2 Zone 3 Zone 4 Zone 5

(Casper) (Denver) (Portland) (Las Vegas) (Phoenix)

Heated by Natural Gas or Fuel $0 i 1$

$\begin{array}{llllll}\begin{array}{l}\text { Base Specification } \\ \text { (Kbtu/sq.ft. } \\ \text { primary energy) }\end{array} & 270.4 & 220.0 & 198.8 & 253.8 & 246.8 \\ \begin{array}{l}\text { Percentage Reduction } \\ \text { due to: }\end{array} & & & & & \\ \quad \text { Caulking } & -7.8 & -6.1 & -6.7 & -9.1 & -6.6 \\ \quad \text { Insulation } & -7.1 & -7.1 & -6.9 & -6.6 & -5.3 \\ \quad \text { Treated Windows } & -6.4 & -5.9 & -6.9 & -5.4 & -4.4\end{array}$

Heated by Electricity

Base Specification

$\begin{array}{llllll}\text { (Mbtu, primary energy) } & 415.1^{*} & 341.8 & 296.9 & 394.3^{*} & 380.4^{*}\end{array}$

Percentage Reduction

due to:

$\begin{array}{lccccc}\text { Caulking } & -9.2^{\star} & -7.2 & -7.8 & -10.7^{\star} & -7.8^{\star} \\ \text { Insulation } & -9.6^{\star} & -9.6 & -9.0 & -8.9^{\star} & -7.2 \\ \text { Treated Windows } & -8.7^{\star} & -8.0 & -7.0 & -7.3^{\star} & -6.0^{\star}\end{array}$

*Imputed 
the fact that an electric system (where electricity is measured in source or "primary" Btus), for heating accounts for a larger percentage of total building energy use than a system directly burning a fossil fuel. This simply reflects that electricity, after accounting for generation and transmission losses, is a less efficient method of space heating. As a result, the retrofit measures, which affect heating loads equally regardless of fuel used, have a greater relative impact on total energy consumption.

The figures in Table B.29 with asterisks represent imputed values. The imputation was performed in order to reduce the number of individual DOE-2 simulations. Generally, imputation was performed to fill out the values for the complete set of weather zones for one of the heating fuel categories. In most cases, complete sets of DOE-2 runs were performed for Denver for buildings heated both by gas/oil and electricity. Then, the percentage variation across weather zones was imputed to the heating fuel for which a DOE-2 run was not performed. An example best illustrates the procedure.

In the case of assembly buildings, a complete set of runs were made for buildings heated by $0 i 1$, gas, or other fossil fuel (LPG, steam). The caulking measure saves 6.1 percent of total energy use in a building located in Denver; 7.8 percent for the same building in Casper. An adjustment factor was then computed as the ratio of $7.8 / 6.1 \quad(=1.28)$ which was then applied to the 7.2 percentage reduction for buildings heated by electricity in Denver. The imputed figure for Casper, 9.2, was arrived at by multiplying 7.2 by 1.28 . This general imputation procedure was performed in a similar manner for the other building types in the subsequent tables.

\section{B.4 COMPUTATION OF AGGREGATE ENERGY SAVINGS}

The first step in computing estimates of aggregate savings is to construct energy use indexes for each building prototype-weather zone combination. The year 1972 is used as the base year for the analysis, and the index can be regarded as having a value of 1.00 in this year. In subsequent years, the index is calculated as:

$$
I_{t}=1.00-\sum_{k} f_{t}^{k} \cdot r^{k}
$$


where $f_{t}^{k}$ is the cumulative percentage of floor space covered by measure $k$

and $r^{k}$ is the percentage energy reduction from implementing retrofit measure $k$

The $f_{t}^{k}$ were taken from the NBECS survey results as shown in Tables B.3 through B.26. The $r^{k}$ were, of course, based on the DOE-2 simulation results that were discussed in the previous section. The summation over the retrofit measures in Equation $B .1$ reflects the additivity assumption discussed earlier.

The index I, was constructed through 1979. To convert the index to a series on energy use, a one year lag was assumed between the year of the retrofit action and the reduction in energy consumption. Retrofits were assumed to be made during the spring to fall period with the most effect on heating loads in the January to March period. Using this assumption, a hypothetical energy consumption series for each year $t, E_{t}$, was calculated by dividing 1979 actual consumption from NBECS by $I_{t-1}$. In other words, we know 1979 consumption for all buildings of a given type and weather zone. By dividing this value by $I_{t}$, we obtain higher values for years earlier than 1979, reflecting the fact that more of the stock had not yet been retrofitted. With the assumption of a one year lag, the base year consumption is arrived at by considering only retrofits completed by 1978. The procedure then allows for an estimate of energy consumption for 1980.

In addition to the building type-weather zone breakdown, separate calculations were performed for fossil fuels versus electricity. For buildings heated by electricity, the $r^{k}$ values were taken directly from Tables B.29 through B.36. 1979 energy consumption for these buildings for NBECS only used the electricity component. For buildings not heated with electricity, separate consumption series $\left(E_{r}\right)$ were computed for both total fossil fuels and for electricity. The percentage reduction values $\left(r_{k}\right)$ were taken from the DOE-2 results which showed separate totals by fuel. Since these buildings are heated by gas, 0il, LPG, or steam; the energy savings principally affect the aggregate fossil fuels category. However, to the extent that the retrofit actions also 
TABLE B.30. Simulated Energy Reductions for Retrofit Measures:

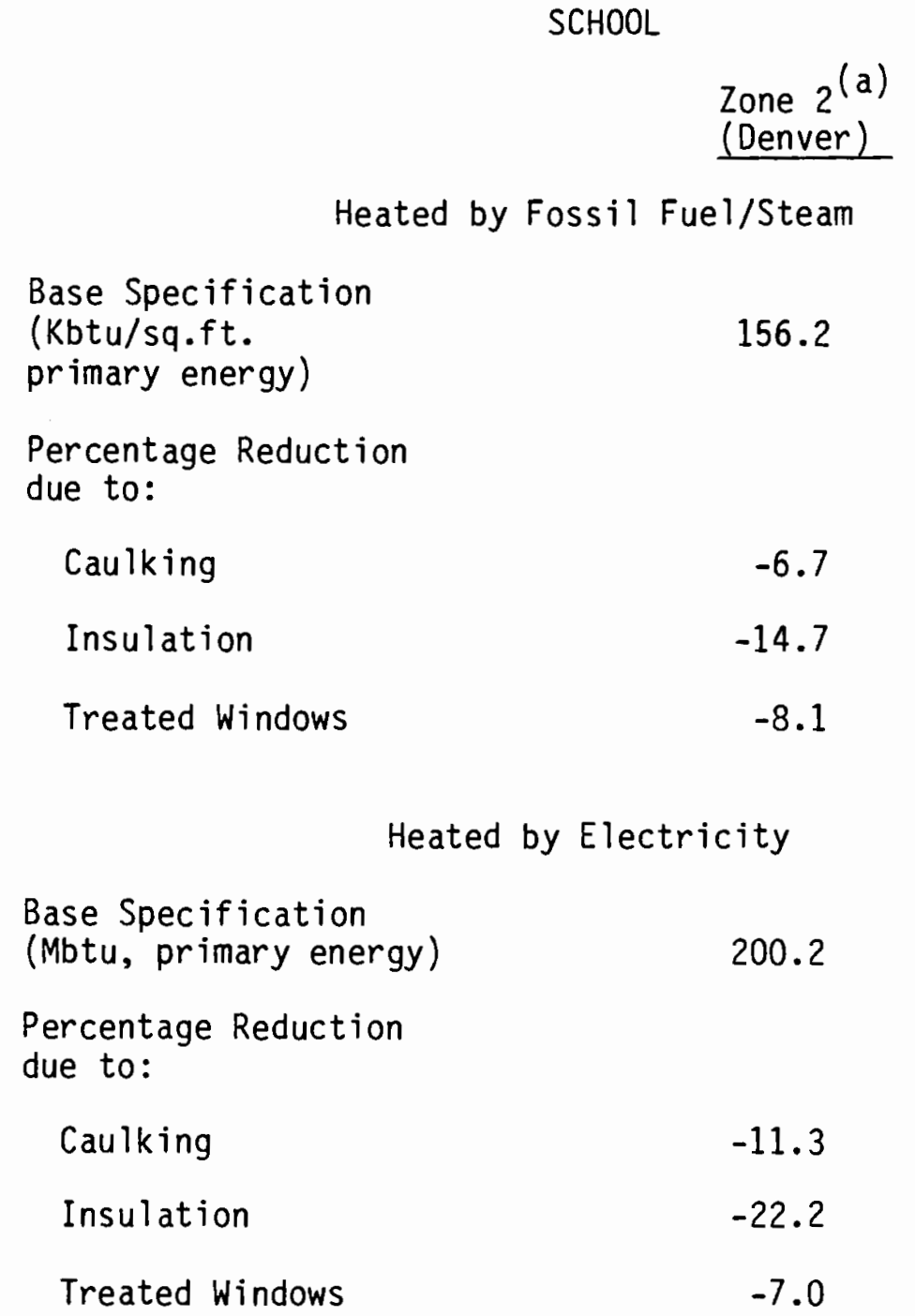

(a) Since this was the only zone for which information was available, the percentage energy reduction for Denver was used for all other zones. 
TABLE B.31. Simulated Energy Reductions for Retrofit Measures:

SMALL GROCERY BUILDING

Zone 1 Zone 2 Zone $3 \quad$ Zone $4 \quad$ Zone 5

(Casper) (Denver) (Portland) (Las Veqas) (Phoenix)

Heated by Natural Gas or Fuel 0 il

\begin{tabular}{|c|c|c|c|c|c|}
\hline $\begin{array}{l}\text { Base Specification } \\
\text { (Kbtu/sq.ft. } \\
\text { primary energy) }\end{array}$ & 835.7 & 808.1 & 753.0 & 889.4 & 923.3 \\
\hline $\begin{array}{l}\text { Percentage Reduction } \\
\text { due to: }\end{array}$ & & & & & \\
\hline Caulking & -4.5 & -2.5 & -1.3 & -2.1 & -0.6 \\
\hline Insulation & -19.3 & -16.7 & -15.5 & -16.1 & -17.9 \\
\hline Treated Windows & -3.9 & -3.9 & -3.6 & -4.6 & -4.1 \\
\hline
\end{tabular}

Heated by Electricity

Base Specification

$\begin{array}{llllll}\text { (Mbtu, primary energy) } & 969.3^{*} & 960.0 & 1620.4^{*} & 1208.1^{\star} & 1278.1^{*}\end{array}$

Percentage Reduction due to:

$\begin{array}{lrrrrr}\text { Caulking } & -3.0^{\star} & -1.7 & -0.9 * & -1.5^{\star} & -0.4^{\star} \\ \text { Insulation } & -28.8^{\star} & -24.9 & -23.1^{\star} & -24.0^{\star} & -26.7^{\star} \\ \text { Treated Windows } & -4.7^{\star} & -4.7 & -4.4^{\star} & -5.5^{\star} & -4.9 *\end{array}$

*Imputed 
TABLE B.32. Simulated Enerqy Reductions for Retrofit Measures:

\title{
SUPERMARKET
}

\author{
Zone 1 Zone 2 Zone 3 Zone 4 Zone 5 \\ (Casper) (Denver) (Portland) (Las Vegas) (Phoenix) \\ Heated by Natural Gas or Fue $10 i 1$
}

\begin{tabular}{|c|c|c|c|c|c|}
\hline $\begin{array}{l}\text { Base Specification } \\
\text { (Kbtu/sq.ft. } \\
\text { primary energy) }\end{array}$ & 586.4 & 558.8 & 547.9 & 581.0 & 596.9 \\
\hline $\begin{array}{l}\text { Percentage Reduction } \\
\text { due to: }\end{array}$ & & & & & \\
\hline Caulking & -1.8 & -0.2 & -0.2 & -0.9 & -0.3 \\
\hline Insulation & $-17 \cdot 3$ & -15.7 & -14.0 & -16.5 & -17.4 \\
\hline Treated Windows & -2.3 & -0.4 & -0.0 & -0.4 & -2.3 \\
\hline
\end{tabular}

Heated by Electricity

Base Specification

(Mbtu, primary energy) $734.2^{\star} \quad 699.6 \quad 685.9^{\star} \quad 727.4^{\star} \quad 747.3^{\star}$

Percentage Reduction

due to:

$\begin{array}{lccccc}\text { Caulking } & -2.7^{\star} & -0.3 & -0.3^{\star} & -1.4^{\star} & -0.5^{\star} \\ \text { Insulation } & -22.0^{\star} & -20.0 & -17.8^{\star} & -21.0^{\star} & -22.2^{\star} \\ \text { Treated Windows } & -0.0^{\star} & -0.0 & -0.0 \star & -0.0 * & -0.0^{\star}\end{array}$

*Imputed 
TABLE B.33. Simulated Energy Reductions for Retrofit Measures:

SMALL OFFICE BUILDING

$\begin{array}{ccccc}\text { Zone } 1 & \text { Zone } 2 & \text { Zone } 3 & \text { Zone } 4 & \text { Zone } 5 \\ \text { (Casper) } & \text { (Denver) } & \text { (Port land) } & \text { (Las Vegas) } & \text { (Phoen ix) }\end{array}$
Heated by Natural Gas or Fue $10 i 1$

\begin{tabular}{|c|c|c|c|c|c|}
\hline $\begin{array}{l}\text { Base Specification } \\
\text { (Kbtu/sq.ft. } \\
\text { primary energy) }\end{array}$ & 319.5 & 279.9 & 216.1 & 253.2 & 259.3 \\
\hline \multicolumn{6}{|l|}{$\begin{array}{l}\text { Percentage Reduction } \\
\text { due to: }\end{array}$} \\
\hline Caulking & $-1.3^{*}$ & -1.0 & $-1.0 \star$ & $-1.0 *$ & $-1.0 *$ \\
\hline Insulation & $-6.8^{\star}$ & -3.7 & $-3.3 \star$ & $-2.3^{\star}$ & $-1.8 *$ \\
\hline Treated Windows & $-1.7 *$ & -1.3 & $-1.0 *$ & $-1.0 *$ & $-1.0 *$ \\
\hline \multicolumn{6}{|c|}{ Heated by Electricity } \\
\hline $\begin{array}{l}\text { Base Specification } \\
\text { (Mbtu, primary energy) }\end{array}$ & 351.3 & 307.8 & 237.6 & 278.4 & 285.1 \\
\hline \multicolumn{6}{|l|}{$\begin{array}{l}\text { Percentage Reduction } \\
\text { due to: }\end{array}$} \\
\hline Caulking & -2.4 & -0.7 & -0.4 & -0.5 & -0.5 \\
\hline Insulation & -10.0 & -8.2 & -4.9 & -3.4 & -2.6 \\
\hline Treated Windows & -3.3 & -2.6 & -1.8 & -1.7 & -1.7 \\
\hline
\end{tabular}


TABLE B.34. Simulated Energy Reductions for Retrofit Measures:

LARGE OFFICE BUILDING

$\begin{array}{ccccc}\text { Zone } 1 & \text { Zone } 2 & \text { Zone } 3 & \text { Zone } 4 & \text { Zone } 5 \\ \text { (Casper) } & \text { (Denver) } & \text { (Portland) } & \text { (Las Vegas) } & \text { (Pheon ix) }\end{array}$

Heated by Natural Gas or Fuel 0 il

Base Specification (Kbtu/sq.ft. primary energy)

$\begin{array}{lllll}548.8 & 496.0 & 482.1 & 407.6 & 396.4\end{array}$

Percentage Reduction due to:

$\begin{array}{llllll}\text { Caulking } & -3.4 & -2.3 & -2.6 & -1.5 & -1.1 \\ \text { Insulation } & -3.6 & -3.7 & -2.7 & -1.9 & -1.6 \\ \text { Treated Windows } & -4.6 & -3.1 & -2.3 & -0.0 & -0.0\end{array}$

Heated by Electricity

Base Specification

(Mbtu, primary energy)

$682.1^{\star} \quad 616.5$

$599.2^{\star}$

$506.6^{*}$

$492.7^{\star}$

Percentage Reduction due to:

Caulking
Insulation
Treated Windows

$-4 \cdot 6^{\star}$

$-3.1$

$-3.5^{\star}$

$-2.0^{\star}$

$-1.5^{\star}$

$-4.9 * \quad-5.0$

$-4.1^{*}$

$-2.6^{\star}$

$-2.2 *$

$-1.5 * \quad-1.0$

-1.0 *

$-0.0 *$

-0.0 *

*Imputed 
TABLE B.35. Simulated Energy Reductions for Retrofit Measures:

SMALL RETAIL BUILDING

$\begin{array}{ccccc}\text { Zone } 1 & \text { Zone } 2 & \text { Zone } 3 & \text { Zone } 4 & \text { Zone } 5 \\ \text { (Casper) } & \text { (Denver) } & \text { (Port Iand) } & \text { (Las Vegas) } & \text { (Phoenix) }\end{array}$
Heated by Natural Gas or Fue $10 i 1$

\begin{tabular}{|c|c|c|c|c|c|}
\hline $\begin{array}{l}\text { Base Specification } \\
\text { (Kbtu/sq.ft. } \\
\text { primary energy) }\end{array}$ & 297.1 & 280.0 & 253.1 & 320.1 & 324.9 \\
\hline $\begin{array}{l}\text { Percentage Reduction } \\
\text { due to: }\end{array}$ & & & & & \\
\hline Caulking & -3.6 & -2.1 & -2.1 & -1.6 & -0.0 \\
\hline Insulation & -11.3 & -9.3 & -7.9 & -9.2 & -6.9 \\
\hline Treated Windows & -5.7 & $-5.1^{\star}$ & -6.0 & -7.2 & -6.5 \\
\hline
\end{tabular}

Heated by Electricity

Base Specification

$\begin{array}{llllll}\text { (Mbtu, primary energy) } & 336.6^{\star} & 317.2 & 286.7^{\star} & 362.6^{\star} & 368.1^{\star}\end{array}$

Percentage Reduction due to:

$\begin{array}{lccccc}\text { Caulking } & -7.0^{\star} & -4.1 & -4.1^{\star} & -3.1^{\star} & -0.0^{\star} \\ \text { Insulation } & -17.4^{\star} & -14.3 & -12.2^{\star} & -14.2^{\star} & -10.6^{\star} \\ \text { Treated Windows } & -6.9^{\star} & -6.2 & -7.3^{\star} & -8.8^{\star} & -7.9^{\star}\end{array}$

*Imputed 
TABLE B.36. Simulated Energy Reductions for Retrofit Measures:

LARGE RETAIL BUILDING

$\begin{array}{ccccc}\text { Zone } 1 & \text { Zone } 2 & \text { Zone } 3 & \text { Zone } 4 & \text { Zone } 5 \\ \text { (Casper) } & \text { (Denver) } & \text { (Portland) } & \text { (Las Vegas) } & \text { (Phoenix) }\end{array}$

Heated by Natural Gas or Fuel 0 il

\begin{tabular}{|c|c|c|c|c|c|}
\hline $\begin{array}{l}\text { Base Specification } \\
\text { (Kbtu/sq.ft. } \\
\text { primary energy) }\end{array}$ & na & 451.8 & na & na & na \\
\hline \multicolumn{6}{|l|}{$\begin{array}{l}\text { Percentage Reduction } \\
\text { due to: }\end{array}$} \\
\hline Caulking & na & na & na & na & na \\
\hline Insulation & $-4.9 \star$ & $-5.5^{\star}$ & $-3.8 \star$ & $-2.6^{\star}$ & $-1.8^{*}$ \\
\hline Treated Windows & $-1.5^{\star}$ & $-1.1^{\star}$ & $-1.1 \star$ & $-1.0 \star$ & $-0.9 *$ \\
\hline \multicolumn{6}{|c|}{ Heated by Electricity } \\
\hline $\begin{array}{l}\text { Base Specification } \\
\text { (Mbtu, primary energy) }\end{array}$ & 462.1 & 461.5 & 456.2 & 510.1 & 525.4 \\
\hline \multicolumn{6}{|l|}{$\begin{array}{l}\text { Percentage Reduction } \\
\text { due to: }\end{array}$} \\
\hline Caulking & na & na & na & na & na \\
\hline Insulation & -6.3 & -7.1 & -4.9 & -3.3 & -2.3 \\
\hline Treated Windows & -1.8 & -1.3 & -1.2 & -1.0 & -0.9 \\
\hline
\end{tabular}


help to reduce cooling loads and reduce power requirements for HVAC equipment, electricity consumption in these buildings is also reduced. Over all the nonelectrically heated building-types analyzed, savings in electricity accounted for about 20 percent of the total energy savings. 
APPENDIX C

THE INDUSTRIAL SECTOR: DATA AND STATISTICAL ESTIMATES 
APPENDIX C

THE INDUSTRIAL SECTOR: DATA AND STATISTICAL ESTIMATES

This technical appendix will document the source of the data used in the analysis of the industrial sector and explain how estimates were derived. The appendix is divided into two sections; the first section provides information about the sources of the data and a listing of the relevant variables. The second section explains the estimating techniques and reports the statistical results.

\section{C.1 DATA}

The data series used to construct lines $B$ through $E$ are obtained from standard publications. The figures for gross national product (GNP) are obtained from Table 6.2 of the National Income and Product Accounts published by the Department of Commerce. The GNP figures are updated by revisions published in the July issue of the Survey of Current Business. Industrial sector GNP (IGNP) was obtained by summing over GNP originating in: agriculture, forestry and fisheries, mining, construction and manufacturing. These numbers are adjusted for inflation and are reported in constant (1972) dollars. Industrial sector energy use (ENERGY) is taken from the most recent SEDS data base available from the Energy Information Agency of the Department of Energy. The energy-GNP ratio (IENGNP) is constructed by dividing energy use by GNP, and is reported in thousands of Btus per dollar of GNP originating in the industrial sector. IGNP and IENGNP are the activity and intensity variables, respectively, used to construct lines $A$ through $E$ shown in $F$ igure 4.1 of the main report.

The data used in the decomposition of energy savings were obtained from a variety of sources. The producer price indexes used to construct a relative price variable (RELPRI) were obtained from the 1983 Economic Report of the President; it is constructed by dividing the index for fuel and related products and power (PPIF) by the index for all industrial commodities (PPIND). The industrial production index (IPVA) and the capacity utilization index are 
also obtained from this document. The ratio of new to existing capital stock for the industrial sector (RI) is obtained by dividing the sum of the most recent three years of investment by the existing net capital stock. These data are obtained from the Bureau of Industrial Economics of the Dedartment of Commerce by inout-output sectors and aggreated to the industrial sector level as were the GNP figures. The energy-weighted industrial oroduction index (IPEW), a uniquely constructed index built up from approximately 450 SICs (Standard Industrial Classifications), is from Marlay (1983). The ratio of energy-weighted to value-added weighted production (RIVE) is constructed by dividing IPEW by IPVA. The ratio of industrial GNP to total GNP (RATIO) is constructed by dividing IGNP by total GNP. Table C.1 is a tabulation of these variables.

\section{C.2 REGRESSION ANALYSIS}

Trends for the energy use intensity measure (IENGNP) and econmic activity measure (IGNP) in Table C.1 were obtained by regressing the logarithm of these dependent variables against time. The sample period was from 1960 through 1972. We estimated that economic activity grew 3.64 percent per year, and that energy use intensity grew at a negative annual rate of 0.097 percent. The trended values calculated from the regressions are reported in Table $C .1$ as EGRHAT (trended energv use intensity) and GNPHAT (trended economic activity.)

The decomposition of energy savings (Line $C$ minus Line A) in Figure C.1 followed a fairly simole strategy. First energy savings (DIFI) were regressed against alternative sets of independent variables to determine the explanatory value of such factors as changing relative prices, changes in capacity utilization, etc. The residuals shown in Figure C.1 were obtained from the regression and are defined as the predicted energy savings minus actual enerqy savings. The explained variation was then decomposed into two components--that attributable to changes in the mix of output as a result of shifts within the industrial sector and that attribute to changes in efficiency. The explained variation of the regression attributahle to efficiency is based on the indedendent work of Marlay (1983). These efficiency changes may be accelerated as a condition of survival under harsh economic circumstances or they may be stimulated by dramatic changes in costs or inout prices. 
TABLE C.1. Data Used in the Analysis

\begin{tabular}{|c|c|c|c|c|c|c|c|}
\hline obs & I PEW & I PVA & RIVE & PPIE & PPIND & RELPRI & \multirow{2}{*}{$\begin{array}{c}R 1 \\
=======\end{array}$} \\
\hline & 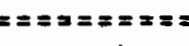 & $== \pm=$ & $=$ & $==$ & $=$ & 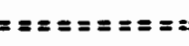 & \\
\hline 1960 & 72.00000 & 69.10000 & 0.959722 & 96.10000 & 95.30000 & 1.008395 & 0.081477 \\
\hline 1961 & 72.60000 & 69.00000 & 0.950413 & 97.20000 & 94.80000 & 1.025316 & 0.076175 \\
\hline 1962 & 77.30000 & 74.40000 & 0.962484 & 96.70000 & 94.80000 & 1.020042 & 0.080663 \\
\hline 1963 & 82.00000 & 78.50000 & 0.957317 & 96.30000 & 94.70000 & 1.016896 & 0.090671 \\
\hline 1969 & 88.20000 & 83.40000 & 0.945578 & 93.70000 & 95.20000 & 0.984244 & 0.108906 \\
\hline 1965 & 94.60000 & 91.30000 & 0.965116 & 95.50000 & 96.40000 & 0.990664 & 0.142166 \\
\hline 1966 & 100.0000 & 98.70000 & 0.987000 & 97.80000 & 98.50000 & 0.992893 & 0.184330 \\
\hline 1967 & 100.0000 & 100.0000 & 1.000000 & 100.0000 & 100.0000 & 1.000000 & 0.218244 \\
\hline 1968 & 105.6000 & 105.6000 & 1.006155 & 98.90000 & 102.5000 & 0.964878 & 0.215195 \\
\hline 1969 & 111.9000 & 109.8000 & 0.990349 & 100.9000 & 106.0000 & 0.951887 & 0.196436 \\
\hline 1970 & 110.3000 & 105.6000 & 0.96817 .8 & 106.2000 & 110.0000 & 0.965455 & 0.169302 \\
\hline 1971 & 111.4000 & 107.0000 & 0.969651 & 115.2000 & 114.1000 & 1.009641 & 0.148120 \\
\hline 1972 & 120.7000 & 117.0000 & 0.981856 & 118.6000 & 117.9000 & 1.005937 & 0.130532 \\
\hline 1973 & 129.7000 & 126.9000 & 0.992907 & 134.3000 & 125.9000 & 1.066720 & 0.133142 \\
\hline 1974 & 129.3000 & 126.0000 & 0.993426 & 208.3000 & 153.8000 & 1.354356 & 0.163693 \\
\hline 1975 & 115.0000 & 114.0000 & 1.009217 & 245.1000 & 171.5000 & 1.429155 & 0.176021 \\
\hline 1976 & 128.6000 & 126.9000 & 1.004743 & 265.6000 & 182.4000 & 1.456140 & 0.180006 \\
\hline 1977 & 134.4000 & 134.7000 & 1.019643 & 302.2000 & 195.1000 & 1.548949 & 0.177689 \\
\hline 1978 & 141.8000 & 143.1000 & 1.023766 & 322.5000 & 209.9000 & 1.540115 & 0.193720 \\
\hline 1979 & 146.8000 & 150.0000 & 1.033447 & 408.1000 & 236.5000 & 1.725581 & 0.217135 \\
\hline 1980 & 139.0000 & 144.6000 & 1.048633 & 574.0000 & 274.5000 & 2.091075 & 0.217191 \\
\hline 1981 & 144.9000 & 151.8000 & 1.034162 & 694.5000 & 304.1000 & 2.283788 & 0.206860 \\
\hline 1982 & 124.3000 & 138.0000 & 1.100724 & 677.4000 & 310.7000 & 2.180238 & 0.165881 \\
\hline
\end{tabular}




\section{TABLE C.1. (cont'd)}

\begin{tabular}{|c|c|c|c|c|c|c|c|}
\hline obs & ENERGY & IGNP & JENCNP & \multirow{2}{*}{$\begin{array}{c}\text { ECRHAT } \\
===\approx x=2=\end{array}$} & \multirow{2}{*}{$\begin{array}{c}\text { CNPHAT } \\
=x==2=x=\end{array}$} & RATIO & $\mathrm{CU}$ \\
\hline \multicolumn{6}{|c|}{ 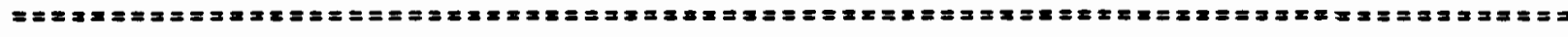 } & & \\
\hline 1960 & 20359.00 & 263.5000 & 77.26376 & 75.18633 & 268.3710 & 0.357434 & 80.10000 \\
\hline 1961 & 20496.00 & 264.1000 & 77.41764 & 75.11321 & 278.3194 & 0.399062 & 77.30000 \\
\hline 1962 & 21243.00 & 280.7000 & 75.67866 & 75.04011 & 288.6369 & 0.350743 & 81.40000 \\
\hline 1963 & 22176.00 & 299.1000 & 74.14243 & 74.96707 & 299.3368 & 0.359279 & 83.50000 \\
\hline 1964 & 23498.00 & 315.8000 & 74.40785 & 79.89914 & 310.9336 & 0.360338 & 85.70000 \\
\hline 1965 & 24479.00 & 339.6000 & 72.08186 & 74.82125 & 321.9416 & 0.365436 & 89.50000 \\
\hline 1966. & 25785.00 & 357.3000 & 72.16625 & 74.74848 & 333.8762 & 0.362815 & 91.10000 \\
\hline 1967 & 26009.00 & 357.3000 & 72.77918 & 74.67574 & 346.2529 & 0.353273 & 86.53600 \\
\hline 1968 & 27199.00 & 374.8000 & 72.56937 & 74.60306 & 359.0887 & 0.354220 & 86.97700 \\
\hline 1969 & 28909.00 & 383.9000 & 74.00104 & 74.53047 & 372.4003 & 0.352979 & 86.28000 \\
\hline 1970 & 28997.00 & 367.9000 & 78.81761 & 74.45799 & 386.2057 & 0.338891 & 80.10700 \\
\hline 1971 & 28962.00 & 379.0000 & 76.41689 & 79.38552 & 400.5223 & 0.337669 & 79.03300 \\
\hline 1972 & 30219.00 & 406.3000 & 74.37608 & 74.31313 & 415.3701 & 0.392609 & 83.87800 \\
\hline 1973 & 31842.00 & 939.9000 & 72.38464 & 74.24083 & 430.7681 & 0.350714 & 87.77500 \\
\hline 1974 & 30899.00 & 420.0000 & 73.56905 & 74.16857 & 446.7370 & 0.336998 & 84.13800 \\
\hline 1975 & 28568.00 & 393.9000 & 72.52601 & 79.09649 & 463.2974 & 0.319828 & 73.89100 \\
\hline 1976 & 30395.00 & 425.1000 & 71.50083 & 74.02433 & 480.4725 & 0.327453 & 80.14600 \\
\hline 1977 & 31149.00 & 450.6000 & 69.12783 & 73.95229 & 498.2835 & 0.328977 & 82.57900 \\
\hline 1978 & 31490.00 & 473.1000 & 66.56098 & 73.88033 & 516.7555 & 0.328861 & 84.91600 \\
\hline 1979 & 32645.00 & 984.9000 & 67.32316 & 73.80843 & 535.9120 & 0.327768 & 85.94600 \\
\hline 1980 & 30653.00 & 464.7000 & 65.93500 & 73.73665 & 555.7785 & 0.315051 & 80.05900 \\
\hline 1981 & 29292.00 & 479.7000 & 61.03800 & 73.66489 & 576.3812 & 0.316989 & 80.02000 \\
\hline 1982 & 26025.00 & 449.6000 & 58.18500 & 73.59320 & 597.7484 & 0.302679 & 71.47100 \\
\hline
\end{tabular}




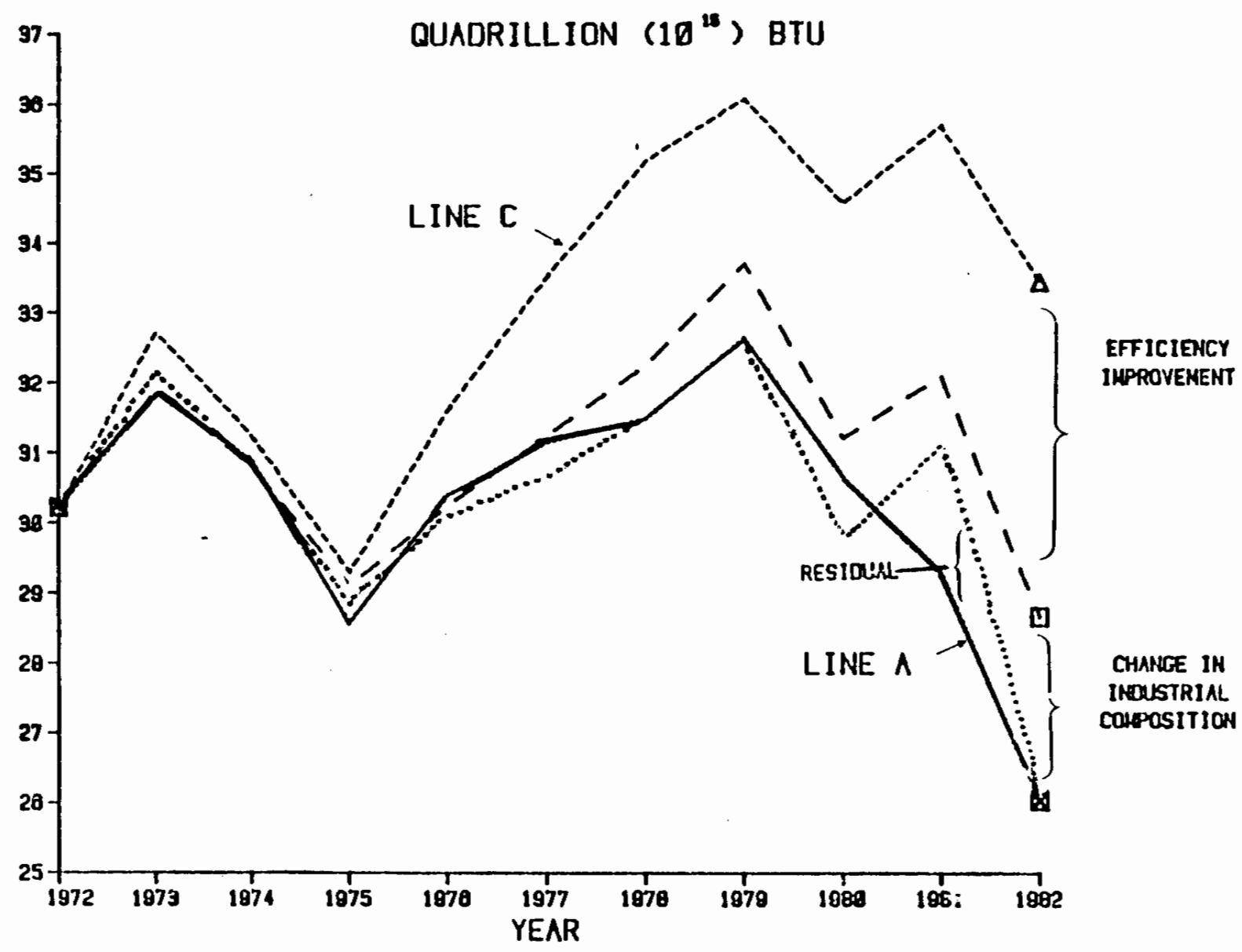

FIGURE C.1. Decomposing Estimated Energy Savings Due to Changes in Energy Use Intensity Since 1972, Industrial Sector 
Table $\mathcal{C} .1$ reports descriptive statistics and the covariance matrix for the explanatory variables used in this analysis. In our regression, energy savings (DIFI) are explained by the ratio of industrial GNP to total GNP (RATIO), capacity utilization (CU), and the ratio of new to existing stock (R1). All variables are significant at the 5 percent level, and the results are generally good. Relative to other regressions which we ran, the explanatory power of this regression is reasonably high--83 percent of the total variation is explained by the regression. Our estimated equation is given by:

$$
\text { DIFI }=106114.3-67640.6 \mathrm{RI}+792.3 \mathrm{CU}-476160.5 \text { RATIO }
$$

The t-statistics are in parentheses. (So as not to exaggerate the graph shown in Figure C.1, the residuals for 1973 and 1974 were reduced to 267 and -103 , respectively.) Unlike any other regression attempted, equation C.1 explained the recession years, 1982 and 1975, very well.

Having determined the residual component (RESIDUAL) in Fiqure C.I from Equation $C .1$ as the difference between predicted and actual energy savings (RESIDUAL = DIFI - DIFI), we can now proceed to explain the portion of energy savings remaining between Line $C$ and Line $A$. First, we shall determine the portion of energy savings attributable to shifts in industrial sector output. That fraction of the change from Line $A$ to Line $C$ is estimated by multiolying the ratio of energy-weighted to value-added industrial production (RIVE) by actual energy used (ENERGY). This provides a measure of what actual energy would have been required by the industrial sector if the composition of output had not changed. Given this measure, we are then able to estimate the component of energy savings attributable to efficiency increases (EFF) as:

$$
E F F=\text { DIF1 - (RIVE } \times \text { ENERGY })- \text { RESIDUAL }
$$

Detailed discussions underlying the rationale for this approach are found in Marley (1983) and Roop (1983). 
APPENDIX D

DETAILED DOCUMENTATION: TRANSPORTATION SECTOR ANALYSIS 


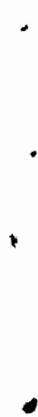

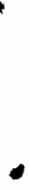


APPENDIX D

\section{DETAILED DOCUMENTATION: TRANSPORTATION SECTOR ANALYSIS}

Trends in total transportation energy use and conservation between 1972 and 1982 were evaluated by aggregating fuel use and activity data on five transportation subsectors: railraods, commercial shipping, commercial trucks, air travel and light-duty highway vehicles (cars and light trucks). Pipelines were not included because dissagregated time series data were not available on energy use and activity in this subsector.

Section D.1 briefly outlines the methodology.

\section{D.1 METHODOLOGY}

Data on total annual transportation energy consumption (measured in trillion Btu) were drawn from material published by the U.S. Energy Information Administration. Statistics on total transportation activity were not available from published sources since the measuring units of activity varied by transportation subsector. (For example, shipping activity was generally expressed in ton-miles while highway vehicle activity was typically expressed in vehicle- or passenger-miles.) For the purpose of this analysis, transportation activity estimates by mode were converted to ton-miles using standard conversion factors from the literature.

The simple aggregation of activity by subsector to the total transportation level did not accurately reflect the relative contributions of each mode to total transportation energy consumption. This arose from the necessity of having to convert passenger-miles to ton-miles for some transportation modes in order to develop an aggregate activity statistic. (In particular, the relative importance of passenger travel by highway vehicles and airplanes was lost in the conversion to ton-miles.) Therefore, the ton-mile estimates by transportation mode were weighted by each subsector's contribution to total energy consumption and were then aggregated to the total transportation level. 
Table D.1a shows total transportation energy use and activity for the period 1960 through 1982. Also illustrated is a measure of total transportation energy use intensity (EUI) expressed as the ratio of total energy consumption to total activity. The table shows that even though total activity increased by 22 percent between 1972 and 1982, total transportation energy use expanded by only 9 percent due to improvements in both the technological and the operational efficiencies of transportation modes.

TABLE D.1a. Energy, Activity and Efficiency in Transportation

$\begin{array}{cccc}\text { Year } & \begin{array}{c}\text { Energy } \\ \text { (Trill. Btu) }\end{array} & \begin{array}{c}\text { Activity } \\ \text { (Trill. Ton-Miles) }\end{array} & \begin{array}{c}\text { EUI } \\ \text { (Btu/Ton-Mile) }\end{array} \\ 1960 & 10250 & 0.176 & 58167 \\ 1961 & 10390 & 0.181 & 57392 \\ 1962 & 10840 & 0.189 & 57337 \\ 1963 & 11230 & 0.198 & 56783 \\ 1964 & 11550 & 0.210 & 56068 \\ 1965 & 11920 & 0.217 & 54877 \\ 1966 & 12540 & 0.232 & 54060 \\ 1967 & 13150 & 0.239 & 54979 \\ 1968 & 14240 & 0.251 & 56707 \\ 1969 & 14850 & 0.263 & 56465 \\ 1970 & 15350 & 0.273 & 56142 \\ 1971 & 15950 & 0.290 & 55087 \\ 1972 & 16910 & 0.308 & 54939 \\ 1973 & 17850 & 0.323 & 55243 \\ 1974 & 17420 & 0.318 & 54728 \\ 1975 & 17630 & 0.317 & 55570 \\ 1976 & 18420 & 0.343 & 53696 \\ 1977 & 19260 & 0.363 & 53067 \\ 1978 & 20040 & 0.388 & 51610 \\ 1979 & 19680 & 0.389 & 50614 \\ 1980 & 19060 & 0.380 & 50157 \\ 1981 & 18840 & 0.380 & 49532 \\ 1982 & 18480 & 0.376 & 49207\end{array}$

To quantify the effects of changes in activity versus fuel efficiency in the total transportation sector, alternative estimates of annual fuel consumption for 1972-1982 were developed using a methodology proposed by Pacific Northwest Laboratory (PNL; Fang and Adams 1983). Case "E" was calculated by extrapolating the historical (1960-1972) growth in activity (4.8 
percent/year) and efficiency (-0.5 percent/year) over the 1972-1982 time period. (These values are listed in Table D.1b.) It, therefore, represented what fuel consumption would have been had historical trends in activity and efficiency continued to occur.

TABLE D.1b. Total Transportation Energy Use and Activity, 1972-1982

\begin{tabular}{|c|c|c|c|c|c|}
\hline \multirow[b]{2}{*}{ Year } & \multirow[b]{2}{*}{$\begin{array}{l}\text { Energy } \\
\text { Use } \\
\text { (Trill. } \\
\text { Btu) } \\
\end{array}$} & \multicolumn{2}{|c|}{ Actual } & \multicolumn{2}{|c|}{ Trended (b) } \\
\hline & & $\begin{array}{l}\text { Activity(a) } \\
\text { Level } \\
\text { (Trill. } \\
\text { Ton-Miles) } \\
\end{array}$ & $\begin{array}{c}\text { Energy } \\
\text { Intensity } \\
\text { (Btu/ } \\
\text { Ton-Mile } \\
\end{array}$ & $\begin{array}{c}\text { Activity } \\
\text { Level } \\
\text { (Trill. } \\
\text { Ton-Miles) }\end{array}$ & $\begin{array}{c}\text { Energy } \\
\text { Intensity } \\
\text { (Btu/ } \\
\text { Ton-Mile } \\
\end{array}$ \\
\hline 1972 & 16910 & 0.308 & 54939 & 0.308 & 54939 \\
\hline 1973 & 17850 & 0.323 & 55243 & 0.317 & 54763 \\
\hline 1974 & 17420 & 0.318 & 54728 & 0.327 & 54587 \\
\hline 1975 & 17630 & 0.317 & 55570 & 0.337 & 54413 \\
\hline 1976 & 18420 & 0.343 & 53696 & 0.348 & 54239 \\
\hline 1977 & 19260 & 0.363 & 53067 & 0.358 & 54065 \\
\hline 1978 & 20040 & 0.388 & 51610 & 0.370 & 53892 \\
\hline 1979 & 19680 & 0.389 & 50614 & 0.381 & 53720 \\
\hline 1980 & 19606 & 0.380 & 50157 & 0.393 & 53548 \\
\hline 1981 & 18840 & 0.380 & 49532 & 0.405 & 53376 \\
\hline 1982 & 18480 & 0.376 & 49207 & 0.418 & 53206 \\
\hline
\end{tabular}

(a) The total activity data have been aggregated from activity statistics by transport mode. These statistics were weighted to account for the relative contribution of each transport mode to total energy consumed by the transportation sector.

(b) Based on an extrapolation of growth rates from 1960 to 1972.

Using the values calculated for Case $E$ and Actual fuel consumption, measures of the total gross energy savings in the transportation sector were derived. These total gross energy savings were then disaggregated to show the relative impacts of changes in activity versus changes in energy use intensity over the 1972-1982 time period. For example, energy savings due to changes in activity were estimated by comparing the product of actual efficiency and trended activity (Case D) versus actual fuel consumption. Similarly, energy 
savings attributable to the incremental improvement in efficiency (over historical growth trends) were calculated by comparing the product of trended growth in efficiency and actual activity (Case $B$ ) versus actual fuel consumption. Table 0.2 shows the numerical values for each of the 5 cases.

TABLE D.2. Actual Transportation Energy Use and Alternative Base Cases

$$
\text { (Trillion Btu) }
$$

\begin{tabular}{lcccccc} 
Year & $\mathrm{A}$ & $\mathrm{B}$ & $\mathrm{C}$ & $\mathrm{D}$ & $E$ \\
\cline { 2 - 3 } 1972 & 16910 & 16910 & 16910 & 16910 & 16910 \\
1973 & 17850 & 17695 & 17752 & 17531 & 17378 \\
1974 & 17420 & 17375 & 17487 & 17906 & 17860 \\
1975 & 17630 & 17263 & 17430 & 18745 & 18354 \\
1976 & 18420 & 18606 & 18846 & 18674 & 18863 \\
1977 & 19260 & 19622 & 19939 & 19028 & 19385 \\
1978 & 20040 & 20926 & 21332 & 19079 & 19922 \\
1979 & 19680 & 20887 & 21361 & 19291 & 20474 \\
1980 & 19060 & 20348 & 20877 & 19709 & 21041 \\
1981 & 18840 & 20299 & 20893 & 20065 & 21624 \\
1982 & 18480 & 19981 & 20632 & 20553 & 22223
\end{tabular}

\footnotetext{
$A=$ Actual energy use

$B=$ Trended EUI with actual activity growth

$C=$ Constant 1972 EUI with actual activity growth

$D=$ Actual EUI with trended activity growth

$E=$ Trended EUI with trended activity growth
}

\section{D.2 HIGHWAY VEHICLES}

\section{D.2.1 Automobiles}

\section{D.2.1.1 Introduction}

To understand recent trends in automobile fuel consumption, it is necessary to evaluate the relative importance of each of the components influencing fuel use and efficiency. As shown in Figure D.1 (and tablulated in Tables $D .3$ and $D .4$ ), automobile fuel consumption rose nearly 14 percent from 
FIGURE D.1. AUTOMOBILE FUEL CONSUMPTION

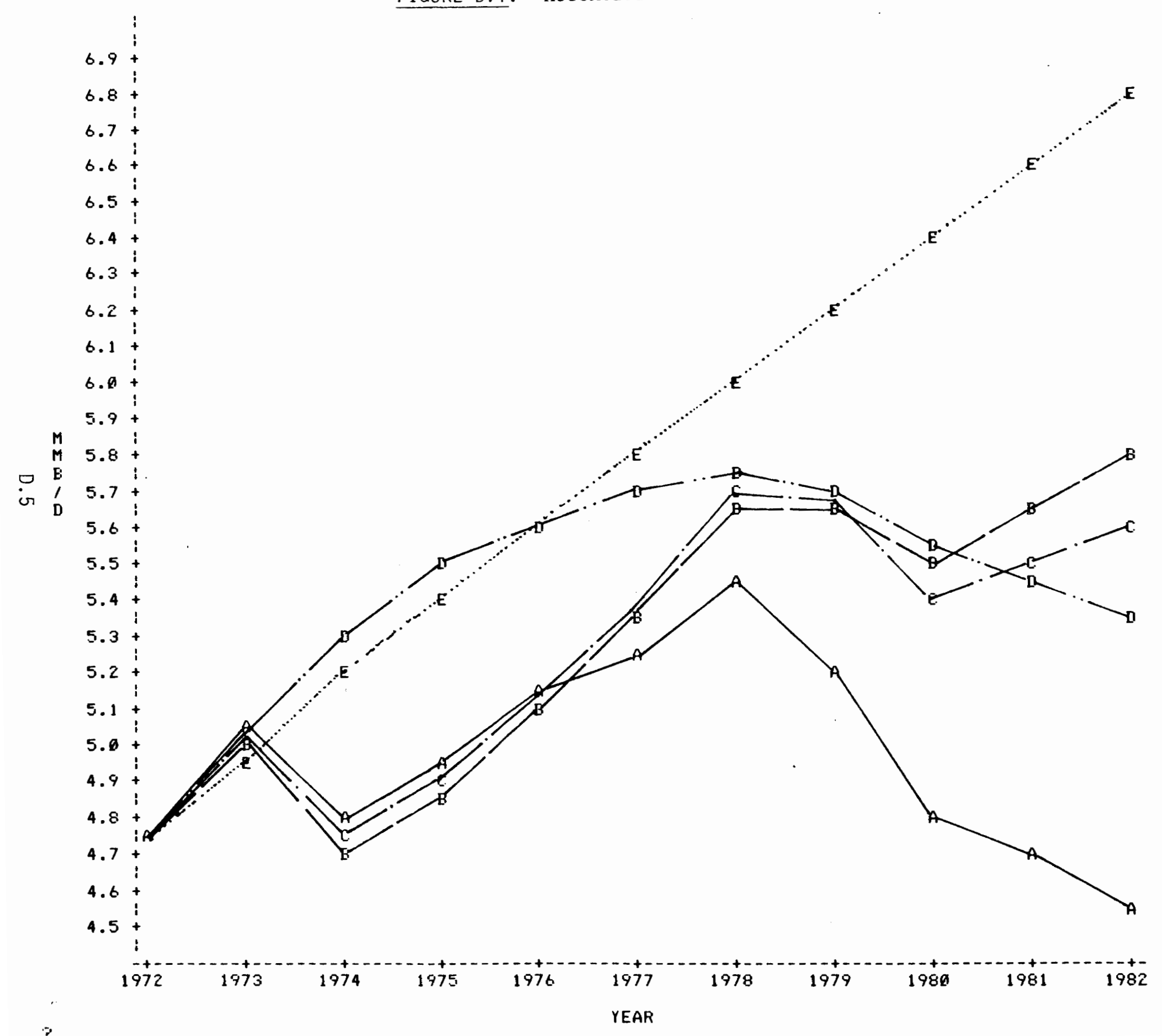


4.77 MMB/D in 1972 to $5.43 \mathrm{MMB} / \mathrm{D}$ in 1982.1 This trend is the product of both changes in activity (travel per vehicle) and changes in the technical and operating efficiency of the automobile fleet. The average annual miles traveled per vehicle actually declined at a rate of 0.6 percent per year in the 1972-1982 time period in comparison to an average growth of 1.1 percent per year in the previous decade. This change in activity yielded fuel savings of $0.8 \mathrm{MMB} / \mathrm{D}$ by 1982 (see Table 0.4 and Figure D.1).

TABLE D.3. Actual Automobile Fuel Use and Alternative Base Cases

$(M M B / D)$

\begin{tabular}{|c|c|c|c|c|c|}
\hline Year & A & $\mathrm{B}$ & $C$ & 0 & $E$ \\
\hline $\begin{array}{l}1972 \\
1973 \\
1974 \\
1975 \\
1976 \\
1977 \\
1978 \\
1979 \\
1980 \\
1981 \\
1982\end{array}$ & $\begin{array}{l}4.77 \\
5.06 \\
4.81 \\
4.96 \\
5.17 \\
5.23 \\
5.43 \\
5.20 \\
4.79 \\
4.68 \\
4.53\end{array}$ & $\begin{array}{l}4.77 \\
4.98 \\
4.69 \\
4.87 \\
5.11 \\
5.34 \\
5.66 \\
5.65 \\
5.51 \\
5.67 \\
5.79\end{array}$ & $\begin{array}{l}4.77 \\
5.02 \\
4.73 \\
4.90 \\
5.16 \\
5.36 \\
5.71 \\
5.66 \\
5.39 \\
5.50 \\
5.58\end{array}$ & $\begin{array}{l}4.77 \\
5.05 \\
5.31 \\
5.49 \\
5.62 \\
5.68 \\
5.76 \\
5.72 \\
5.57 \\
5.46 \\
5.33\end{array}$ & $\begin{array}{l}4.77 \\
4.97 \\
5.18 \\
5.39 \\
5.59 \\
5.80 \\
6.00 \\
6.21 \\
6.41 \\
6.62 \\
6.82\end{array}$ \\
\hline
\end{tabular}

\footnotetext{
$A=$ Actual fuel use

$B=$ Trended fuel efficiency with actual activity growth

$C=$ Constant 1972 fuel efficiency with actual activity growth

$D=$ Actual fuel efficiency with trended activity growth

$E=$ Trended fuel efficiency with trended activity growth
}

1 Actual passenger car fuel demand and the analysis of the components of automobile fuel use and efficiency are based on the output of the Highway Fuel Consumption (HFC) model developed for the Department of Energy under a separate work effort (EEA 1983). 
TABLE D.4. Estimates of Total Automobile Fuel Savings

$(M M B / D)$

\begin{tabular}{|c|c|c|c|c|c|}
\hline Year & TGESE & ACSEB & ACSDA & MEUICS & TOTNES \\
\hline $\begin{array}{l}1972 \\
1973 \\
1974 \\
1975 \\
1976 \\
1977 \\
1978 \\
1979 \\
1980 \\
1981 \\
1982\end{array}$ & $\begin{array}{r}0.00 \\
-0.09 \\
0.37 \\
0.43 \\
0.42 \\
0.57 \\
0.57 \\
1.01 \\
1.62 \\
1.94 \\
2.29\end{array}$ & $\begin{array}{r}0.00 \\
-0.01 \\
0.49 \\
0.52 \\
0.48 \\
0.46 \\
0.34 \\
0.56 \\
0.90 \\
0.95 \\
1.03\end{array}$ & $\begin{array}{r}0.00 \\
-0.01 \\
0.50 \\
0.53 \\
0.45 \\
0.45 \\
0.33 \\
0.52 \\
0.78 \\
0.78 \\
0.80\end{array}$ & $\begin{array}{r}0.00 \\
-0.08 \\
-0.12 \\
-0.09 \\
-0.06 \\
0.11 \\
0.23 \\
0.45 \\
0.72 \\
0.99 \\
1.26\end{array}$ & $\begin{array}{r}0.00 \\
-0.04 \\
-0.08 \\
-0.06 \\
-0.01 \\
0.13 \\
0.28 \\
0.46 \\
0.60 \\
0.82 \\
1.05\end{array}$ \\
\hline
\end{tabular}

\footnotetext{
TGESE = Total gross fuel savings according to Line $E(E-A)$

ACSDA = Activity change savings according to Lines $D$ and $A(D-A)$ $A C S E B=$ Activity change savings according to Lines $E$ and $B(E-B)$ MEUICS = Marginal fuel efficiency change savings $(B-A)$

TOTNES = Total net fuel savings $(C-A)$
}

Changes in the overall fuel efficiency of the fleet also have contributed to fuel savings in the automobile sector. Between 1963 and 1972 the average fuel economy of the fleet actually fell from $14.3 \mathrm{mpg}$ to $13.4 \mathrm{mpg}$. In the subsequent decade this trend reversed. With the rapid introduction of fuelefficient technologies in new cars beginning in 1978, the average fleet fuel economy grew to $16.6 \mathrm{mpg}$ by 1982 . Had the $1960 \mathrm{~s}$ trend in decreasing fuel economy continued, fuel consumption in 1982 would have increased 27.8 percent or $1.26 \mathrm{MMB} / \mathrm{D}$ over what was consumed due to the actual post-1972 trend in fuel economy. These are the fuel savings due to changes in fuel efficiency at the margin which are reported in Table 0.4 and illustrated in Figure 0.1 . Even if fuel savings are measured relative to 1972 levels, the effects of improvements in average fuel efficiency remain significant--on the order of $1.05 \mathrm{MMB} / 0$ in 1982 (as shown in Table D.4).

A number of factors influenced the trend in the average fuel efficiency of the automobile fleet. Perhaps first and foremost is the impact of the 
Corporate Average Fuel Economy (CAFE) standards on the implementation of fuelefficient technologies in new automobiles. Shifts in consumer preferences for large vs. small cars also affect the average fuel efficiency of the fleet (due to the direct correlation between fuel economy and weight).

To understand the recent trends in the overall fuel efficiency of the automobile-fleet, it is essential to assess the relative importance of each of the aforementioned factors influencing efficiency. The analys is that follows decomposes the fuel savings attributable to the improvement in efficiency since 1972 (Line $C$ minus Line $A$ in Figure D.1 and in Table D.4). To place the savings attributable to fuel efficiency in context, the fuel consumption impacts of changes in other factors (principally shifts in the growth of the automobile stock and shifts in activity such as travel per car and speed) also are briefly considered. ${ }^{2}$ (See Table 0.5 for statistics on each of these elements--fleet $\mathrm{mpg}$, travel per car, and vehicle stock--of total automobile fuel consumption in the 1972-1982 period.)

\section{TABLE D.5. Actual Passenger Car Fuel Demand}

(From Highway Fuel Consumption Model)

\begin{tabular}{|c|c|c|c|c|c|}
\hline Year & $\begin{array}{c}\text { Vehicle Stock } \\
(\mathrm{Mil.}) \\
\end{array}$ & F leet MPG & $\begin{array}{l}\text { F leet VMT } \\
(\mathrm{Bi} 1 .) \\
\end{array}$ & VMT/Car & $\begin{array}{c}\text { Consumption } \\
\text { (MMB /D) }\end{array}$ \\
\hline $\begin{array}{l}1972 \\
1973 \\
1974 \\
1975 \\
1976 \\
1977 \\
1978 \\
1979 \\
1980 \\
1981 \\
1982\end{array}$ & $\begin{array}{r}86.44 \\
89.80 \\
92.61 \\
95.24 \\
97.82 \\
99.90 \\
102.96 \\
104.68 \\
104.56 \\
105.84 \\
107.40\end{array}$ & $\begin{array}{l}13.43 \\
13.32 \\
13.21 \\
13.28 \\
13.47 \\
13.75 \\
14.12 \\
14.60 \\
15.13 \\
15.77 \\
16.56\end{array}$ & $\begin{array}{r}982.26 \\
1034.20 \\
974.41 \\
1009.17 \\
1061.76 \\
1103.04 \\
1175.96 \\
1164.69 \\
1110.29 \\
1131.33 \\
1149.90\end{array}$ & $\begin{array}{l}11,369 \\
11,517 \\
10,522 \\
10,596 \\
10,854 \\
11,041 \\
11,421 \\
11,126 \\
10,619 \\
10,689 \\
10,707\end{array}$ & $\begin{array}{l}4.77 \\
5.06 \\
4.81 \\
4.96 \\
5.14 \\
5.23 \\
5.43 \\
5.20 \\
4.79 \\
4.68 \\
4.53\end{array}$ \\
\hline
\end{tabular}

2 This analys is updates a study conducted by the Department of Energy in 1982 (DiFiglio and McNutt 1982). The methodology and approach used to disaggregate the components of fuel use and efficiency are identical to those used in the DOE study and will therefore not be repeated here. 


\section{D.2.1.2 Components of Fuel Efficiency}

The efficiency of the fleet (fleet MPG) is influenced by manufacturers' decision on technology introduction and by consumer preferences for vehicle size. Both the improvement in fuel efficiency within vehicle size class and a shift in the size class mix of new vehicles sold will affect the overall level of fleet efficiency. In addition, the manner in which vehicles are operated (i.e., vehicle speeds) also influences fuel efficiency. The impact of changes in each of these three factors on fuel demand is discussed below.

\section{D.2.1.2.1 Changing Mix Shift. Changes in the mix of vehicles by size} class were evaluated using data developed by the Environmental Protection Agency (EPA). The EPA has developed six size classifications for automobiles based on interior and trunk size dimensions. The percentage of new cars in each of these size classes and the corresponding average fuel economy of vehicles in each of these classes for 1972 through 1982 are presented in Table D.6.

The distribution of the 1972 model year fleet and corresponding size class fuel economy values were estimated by EEA based on EPA data on passengers by weight category.

Two methodologies were employed to calculate a new vehicle mpg which would be used in the HFC model to determine the affect of changes in fleet mix on fuel consumption. Method 1 produced a new vehicle average mpg using the 1972 size class distribution of the fleet (held constant throughout the 1972-82 time period) and the actual fuel economies by size class and model year. Method 2 used size class-specific fuel economy held constant at 1972 levels in conjunction with the shifts in size class distribution which actually occurred over the 1972-82 time period.

The change in new car average mpg using Method 1 was calculated by subtracting the calculated value from the actual mpg value. The change in new car average mpg found by Method 2 was calculated by subtracting the 1972 actual efficiency from the calculated efficiency. 
TABLE D.6. AUTOMOBILE* PRODUCTION BY PERCENT OF EPA

SIZE CLASS AND CORRESPONDING FUEL ECONOMY

MODEL YEARS 1972-1982

(\% Share/MPG)

Mode1

$\frac{\text { Year }}{1972}$

1973

1974

1975

1976

1977

1978

1979

1980

1981

1982

Minicompact

$5.69 / 22.9$

$6.2 / 23.2$

$10.7 / 20.6$

$7.6 / 23.42$

$8.6 / 26.7$

$5.6 / 27.4$

$10.0 / 27.5$

$6.0 / 27.1$

$4.5 / 29.2$

$3.4 / 32.3$

$2.91 / 35.9$

\begin{tabular}{l} 
Subcompact \\
\hline $14.35 / 17.85$ \\
$17.3 / 17.7$ \\
$14.5 / 18.2$ \\
$18.9 / 20.5$ \\
$18.9 / 22.7$ \\
$13.1 / 22.7$ \\
$21.8 / 25.1$ \\
$29.9 / 24.9$ \\
$37.4 / 26.9$ \\
$32.3 / 28.9$ \\
$31.99 / 30.87$
\end{tabular}

\section{Compact}

$7.69 / 17.59$

$8.6 / 16.9$

$11.1 / 13.4$

$24.1 / 16.1$

$24.1 / 17.7$

$27.6 / 18.4$

$14.4 / 20.2$

$8.3 / 19.9$

$6.6 / 23.0$

$13.5 / 28.2$

$31.99 / 30.87$
Two

\begin{tabular}{l}
\multicolumn{1}{c}{ Midsize } \\
$33.11 / 12.59$ \\
$21.1 / 12 / 4$ \\
$29.1 / 13.4$ \\
$21.0 / 14.3$ \\
$21.5 / 15.4$ \\
$21.9 / 17.0$ \\
$30.8 / 19.0$ \\
$34.2 / 19.1$ \\
$34.2 / 21.1$ \\
$35.4 / 23.3$ \\
$33.25 / 25.01$
\end{tabular}

Large

$38.04 / 11.19$

$45.8 / 10.9$

$33.1 / 11.3$

$23.6 / 13.0$

$25.0 / 14.4$

$30.3 / 16.2$

$20.5 / 17.1$

$19.6 / 17.7$

$15.0 / 19.6$

$12.6 / 20.9$

$13.07 / 20.93$

*Includes station wagons.

SOURCES: 1972 - estimated by EEA based on analysis of market shares and fuel economy of passenger cars by weight class.

1973-1977 - U.S. DOT/NHTSA, Automotive Characteristics Historical Data Base, personal conversations between Barry McNutt of DOE and Eric Chen of ORNL, June 1, 1981 .

1978-1981 - Motor Vehicle Quarter MPG and Market Share Newsletters.

1982 - Personal conversation with Mary Holcomb of ORNL. 
The fuel economy values resulting from the analysis are shown in Table D.7. Using both series of estimated new car fuel economy trends, we evaluated the fuel savings impact of a size mix shift as follows:

Fuel Savings $=\left(\right.$ TVMT $\left._{j} / A M P G_{i e}\right)-F C_{i}$

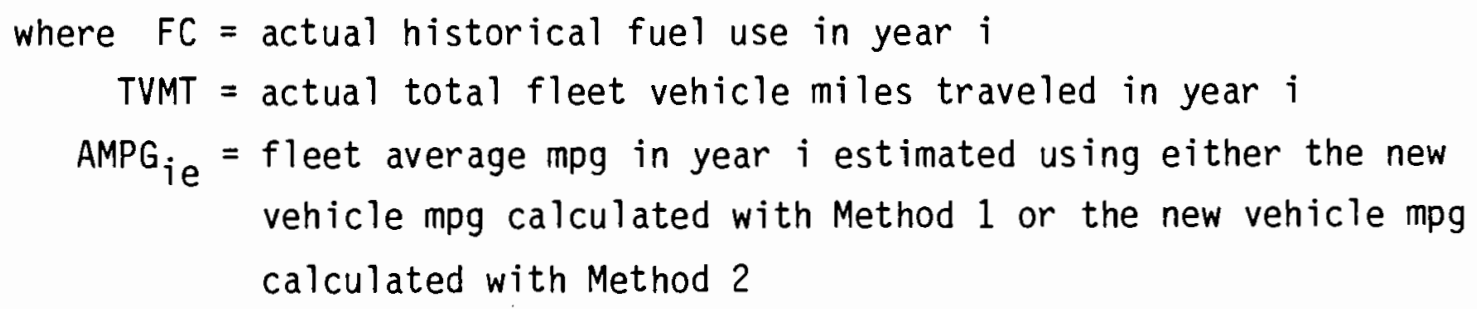

TABLE D.7. Impact of Size Class Shifts on New Car Fuel Economy and Fleet Fuel Consumption

\begin{tabular}{|c|c|c|c|c|c|c|}
\hline $\begin{array}{l}\text { Mode } 1 \\
\text { Year }\end{array}$ & $\begin{array}{l}\text { Actual } \\
\text { MPG }\end{array}$ & \multicolumn{2}{|c|}{ Reweighted MPG } & \multicolumn{2}{|c|}{$M P G \triangle$} & $\Delta$ in Consumption \\
\hline 1972 & 13.2 & -- & -- & -- & -- & - \\
\hline 1973 & 13.0 & 12.9 & 13.25 & 0.1 & 0.05 & 0.0 \\
\hline 1974 & 13.6 & 13.3 & 13.8 & 0.3 & 0.6 & 0.025 \\
\hline 1975 & 15.9 & 14.9 & 14.7 & 1.0 & 1.5 & 0.065 \\
\hline 1976 & 17.4 & 16.3 & 14.6 & 1.1 & 1.4 & 0.11 \\
\hline 1977 & 18.1 & 17.9 & 14.1 & 0.2 & 0.9 & 0.125 \\
\hline 1978 & 20.4 & 19.3 & 14.5 & 1.1 & 1.3 & 0.150 \\
\hline 1979 & 20.6 & 19.6 & 14.3 & 1.0 & 1.1 & 0.160 \\
\hline 1980 & 23.1 & 21.7 & 14.6 & 1.4 & 1.4 & 0.160 \\
\hline 1981 & 25.4 & 23.7 & 14.7 & 1.7 & 1.5 & 0.175 \\
\hline 1982 & 26.99 & 24.7 & 14.7 & 2.3 & 1.5 & 0.175 \\
\hline
\end{tabular}

Fleet average fuel economy was determined by the relative age distribution, travel and fuel economy of each model year represented in the fleet as follows:

$$
A M P G=T V M T / \sum_{t} \sum_{i} \sum_{k}\left(R G_{i} \times P C T_{i t} \times S P_{k} \times V M T_{k} / M P G_{i t}\right)
$$

where $A M P G=$ fleet average fuel economy

$$
\begin{aligned}
\text { TVMT } & =\text { total automobile fleet miles traveled } \\
R G_{i} & =\text { total new automobile registrations of model year } i
\end{aligned}
$$




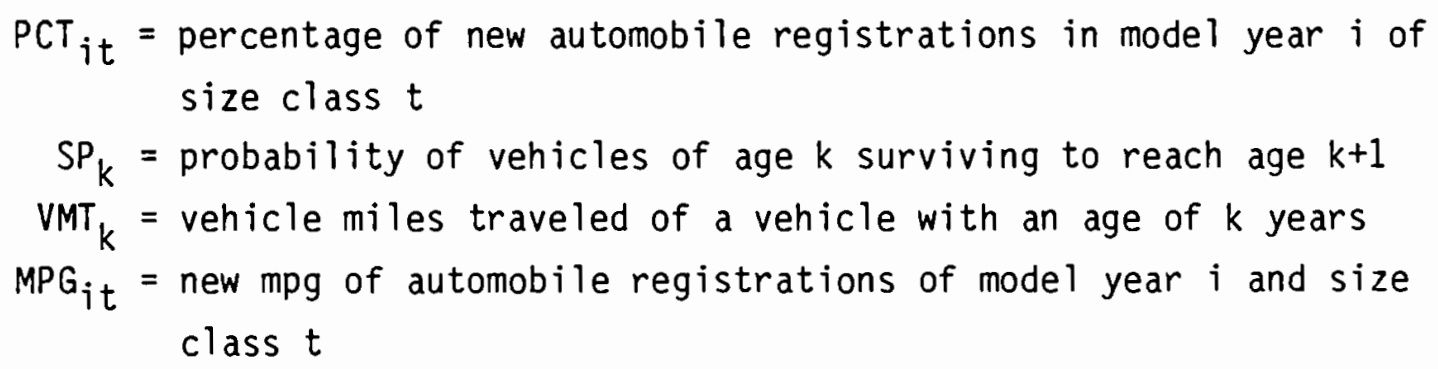

Using the above formulae and the fuel economy values in Table 0.7 , the change in mpg and consumption with Method 1 reveals the effect of shifts from large to small cars. The change in mpg and consumption calculated using Method 2 reveals the impact of the changing emphasis on efficiency created by these shifts. The difference in consumption from both methods was averaged to determine the total fuel savings from size class shifts.

\section{D.2.1.2.2 Technology Improvements. Changes in fleet efficiency were} assumed to be caused solely by two variables--changing mix shift and technological improvements to the fleet. The 1982 DOE analysis of reduction in fuel demand attempted to examine changes in patterns of vehicle use and maintenance, but the little data available did not indicate significant changes in how consumers use and maintain their vehicles. Changes in consumption caused by technology improvements were calculated as the difference between consumption which would have occurred assuming no change in the new vehicle fleet efficiency (mpg) beginning in 1972, and the fuel savings already determined by shifting size classes. The HFC model was used to calculate consumption using the 1972 fuel economy of new vehicles for each model year through 1982 .

The change in consumption attributable to technological improvements to the fleet is presented in Table D.8. From 1973 through 1975, the strategies used to control automotive exhaust emissions had a negative impact on new car fuel economy. However, beginning in 1975-1976, new technologies designed to improve automotive fuel economy have been implemented in increasing volume in response to federal fuel economy standards and consumer demand. After 1978, changes in vehicle technology provided a significant contribution to reductions in fuel demand $(0.825 \mathrm{MMB} / \mathrm{D}$ in 1982). 
TABLE D.8. Impact of New Passenger Car Technology on Fue 1 Consumption

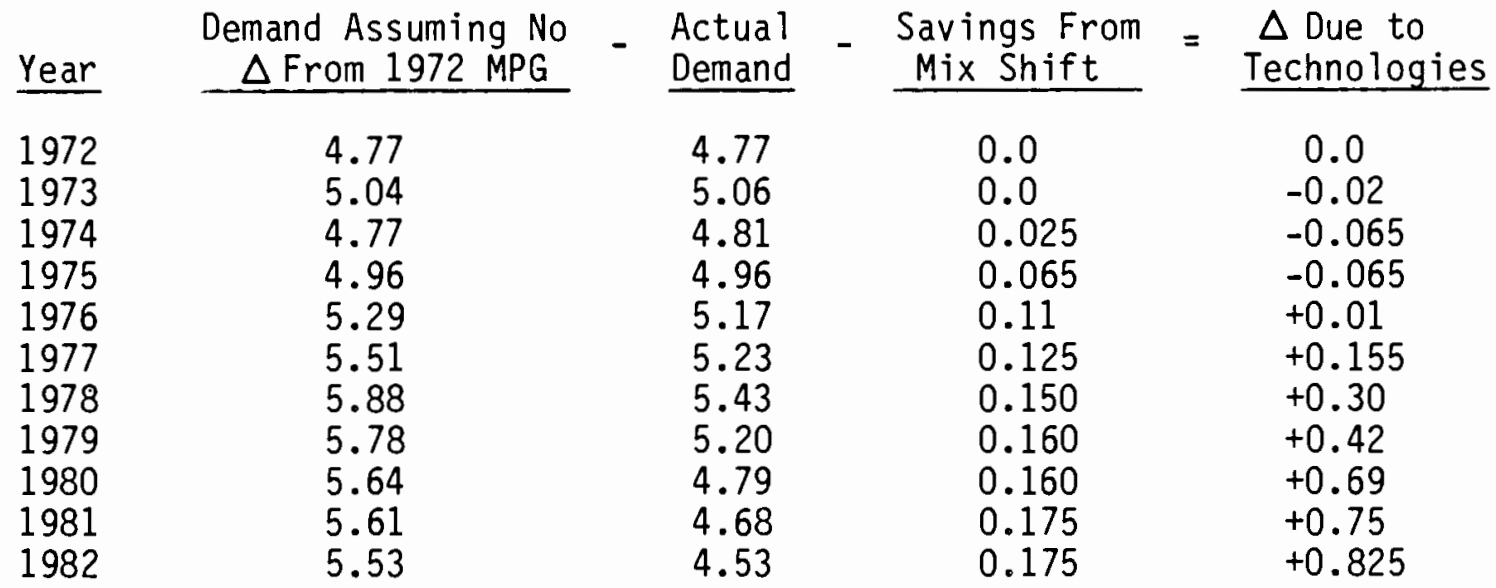

0.2.1.2.3 Total Net Fuel Savings Since 1972. Table D.9 shows the total net savings in automobile fuel use (Line $C$ minus Line $A$ from Figure D.1) and the relative impacts of each of the identified components of changes in automobile fuel efficiency since 1972 (technological improvements in new cars and shifts in the mix of new cars sold). In 1982 about 78 percent of the total net fuel savings was attributable to technology improvements, and 17 percent was accounted for by shifts towards fleets of smaller, lighter new car sales since 1972. The remaining or residual 5 percent of the total net fuel savings in 1982 could not be accurately identified but is probably due to changes in vehicle use and maintenance (i.e., improved driver efficiency, improved vehicle maintenance and/or shifts in vehicle use patterns). The size of this residual has fluctuated significantly over the past decade and has been negative for all but two years (1980 and 1982). While it is logical to believe that several factors may have been working against improvements in fuel efficiency (i.e., increases in traffic congestion, increased waiting times at gasoline stations during the oil supply "crises" of 1973 and 1979, improper tire inflation), it is difficult to quantify the individual impacts of all of these trends. Therefore, the residual component in Table 0.9 should be viewed only as the total unexplained portion of the net fuel savings attributable to the improvements in the overall fuel efficiency of the automobile fleet since 1972. 
TABLE D.9. Components of Total Net Fuel Savings in the Automobile Sector

\begin{tabular}{|c|c|c|c|c|}
\hline Year & $\begin{array}{l}\text { Total Net } \\
\text { Fuel Savings }\end{array}$ & $\begin{array}{l}\text { Technology } \\
\text { Improvements }\end{array}$ & $\begin{array}{l}\text { Mix } \\
\text { Shift }\end{array}$ & Residual \\
\hline $\begin{array}{l}1972 \\
1973 \\
1974 \\
1975 \\
1976 \\
1977 \\
1978 \\
1979 \\
1980 \\
1981 \\
1982\end{array}$ & $\begin{array}{r}0.00 \\
-0.04 \\
-0.08 \\
-0.06 \\
-0.01 \\
0.13 \\
0.28 \\
0.46 \\
0.60 \\
0.82 \\
1.05\end{array}$ & $\begin{array}{l}0.00 \\
-0.02 \\
-0.065 \\
-0.065 \\
0.01 \\
0.155 \\
0.30 \\
0.42 \\
0.69 \\
0.75 \\
0.825\end{array}$ & $\begin{array}{l}0.00 \\
0.00 \\
0.025 \\
0.065 \\
0.11 \\
0.125 \\
0.150 \\
0.160 \\
0.160 \\
0.175 \\
0.175\end{array}$ & $\begin{array}{c}0.00 \\
-0.02 \\
-0.04 \\
-0.06 \\
-0.12 \\
-0.15 \\
-0.17 \\
-0.12 \\
-0.25 \\
-0.105 \\
0.05\end{array}$ \\
\hline
\end{tabular}

\section{D.2.1.3 Vehicle Stock}

Shifts in the size and age distribution of the vehicle stock have a direct impact on consumption. Changes in fleet size and age distributions are the dynamics of new vehicle sales vis-a-vis the scrappage of older vehicles in the fleet. To determine the impact of changes in the fleet on consumption, the number of cars in use in 1972 through 1982 was estimated assuming that historical (1963-1972) rates of growth had not changed. These predicted values were then used in the following equation to calculate annual fuel savings:

$$
\text { FSAV }_{i}=\text { FUELACT }_{i}-\left(\text { STKPRED }_{i} \text { * } \text { AVMTACT }_{j} / \text { MPGACT }_{j}\right)
$$

where FSAV = fuel savings

FUELACT = actual fuel use

STKPRED = predicted stock from historical trends

AVMTACT = actual average annual $\mathrm{VMT} /$ vehicle

MPGACT = actual fleet on-road mpg

$$
i=\operatorname{year}(1972-1982)
$$

Values for the predicted stock and fuel consumption are presented in Tabie 0.10 along with the estimated fuel savings attributed to changes in the growth of cars in operation. 
TABLE 0.10 . Predicted Vehicle Stock and Consumption

\begin{tabular}{|c|c|c|c|c|}
\hline Year & $\begin{array}{c}\text { Projected } \\
\text { Stockk } \\
\left(10^{6}\right) \\
\end{array}$ & $\begin{array}{c}\text { Predicted } \\
\text { Consumption } \\
\text { (MMB } / 0) \\
\end{array}$ & $\begin{array}{c}\text { Actual } \\
\text { Consumption } \\
\text { (MMB/D) } \\
\end{array}$ & $\begin{array}{c}\text { Change in } \\
\text { Consumption }\end{array}$ \\
\hline 1972 & 86.4 & 4.77 & 4.77 & 0.0 \\
\hline 1973 & 88.9 & 5.01 & 5.06 & -0.05 \\
\hline 1974 & 91.4 & 4.75 & 4.81 & -0.06 \\
\hline 1975 & 93.9 & 4.89 & 4.96 & -0.07 \\
\hline 1976 & 96.4 & 5.07 & 5.14 & -0.07 \\
\hline 1977 & 98.9 & 5.18 & 5.23 & -0.05 \\
\hline 1978 & 101.4 & 5.35 & 5.43 & -0.08 \\
\hline 1979 & 103.9 & 5.16 & 5.20 & -0.04 \\
\hline 1980 & 106.4 & 4.87 & 4.79 & +0.08 \\
\hline 1981 & 108.9 & 4.81 & 4.68 & +0.13 \\
\hline 198 & 111.4 & 4.76 & 4.53 & +0.23 \\
\hline
\end{tabular}

The annual growth in the number of cars in operation increased in the 1970s relative to the rate of expansion of the fleet experienced in the 1960s. (This may be attributed to the continued growth of multiple car households caused by the increasing numbers of two wage earner families in the seventies.) As a result, fuel savings due to changes in the stock are primarily negative. Beginning in 1980, however, the annual growth in fleet size slowed considerably (to 1.3 percent for 1980-1982 compared with 2.6 percent/year for 1972-1980). Fuel savings for the 1980s are therefore positive. By 1982, annual fuel consumption is reduced 4.8 percent $(0.23 \mathrm{MMB} / \mathrm{D})$ relative to what would have been used had the stock continued to grow at historical rates over the 19721982 time period.

\section{D.2.1.4 VMT/Vehicle}

Vehicle miles traveled per vehicle is affected by economic and demographic variables which this analysis does not attempt to explain (i.e., fuel price, fuel availability, personal income levels, and urban/rural spatial distributions). For the purpose of this analysis, the 1963-1972 trend in VMT/vehicle is assumed to continue into the 1972-1982 time period. This trend is then compared with the actual VMT/vehicle to quantify the fuel savings 
attributable to reductions in average annual mileage over the 1972-1982 time period. Fuel savings are calculated as follows:

$$
\text { FSAV }_{i}=\text { FUELACT }_{i}-\left(\text { STKACT }_{i} \text { * } \text { AVMTPRED }_{j} / \text { MPGACT }_{j}\right)
$$

where $F S A V=$ fuel savings

$$
\begin{aligned}
\text { FUELACT } & =\text { actual fuel use } \\
\text { STKACT } & =\text { actual stock } \\
\text { AVMTPRED } & =\text { predicted annual } \mathrm{VMT} / \text { vehicle from historical trends } \\
i & =\text { year }(1972-1982)
\end{aligned}
$$

If average annual VMT per car in the 1972-1982 time period had continued at historical rates of change, it would have grown by about one percent per year. In contrast, the actual average annual VMT per car has fluctuated significantly during the decade of the seventies in response to factors such as the oil supply shortages of 1973-74 and 1979 and the economic recession of 1980. As a result, fuel savings attributable to reductions in travel also have fluctuated. Between 1975 and 1978, for instance, fuel savings dropped from $0.53 \mathrm{MMB} / \mathrm{D}$ to $0.43 \mathrm{MMB} / \mathrm{D}$ as average annual VMT increased. After reaching a peak in 1978, however, average annual miles per vehicle have declined-providing annual fuel savings of about $0.8 \mathrm{MMB} / \mathrm{D}$ in 1982 . This represents a 15

\begin{tabular}{|c|c|c|c|c|}
\hline Year & $\begin{array}{l}\text { Predicted } \\
\text { VMT } / V \\
\end{array}$ & $\begin{array}{c}\text { Predicted } \\
\text { Consumpt ion } \\
\text { (MMB/D) }\end{array}$ & $\begin{array}{c}\text { Actual } \\
\text { Consumpt ion } \\
(M M B / D) \\
\end{array}$ & $\begin{array}{l}\text { Fuel } \\
\text { Savings } \\
\text { (MMB/D) }\end{array}$ \\
\hline 1972 & 11,369 & 4.77 & 4.77 & 0.0 \\
\hline 1973 & 11,492 & 5.05 & 5.06 & -0.01 \\
\hline 1974 & 11,615 & 5.31 & 4.81 & 0.50 \\
\hline 1975 & 11,739 & 5.49 & 4.96 & 0.53 \\
\hline 1976 & 11,864 & 5.61 & 5.14 & 0.47 \\
\hline 1977 & 11,987 & 5.67 & 5.23 & 0.44 \\
\hline 1978 & 12,110 & 5.76 & 5.43 & 0.43 \\
\hline 1979 & 12,234 & 5.72 & 5.20 & 0.52 \\
\hline 1980 & 12,357 & 5.57 & 4.79 & 0.78 \\
\hline 1981 & 12,481 & 5.46 & 4.68 & 0.78 \\
\hline 1982 & 12,604 & 5.33 & 4.53 & 0.80 \\
\hline
\end{tabular}
percent reduction in the fuel consumption which would have occurred had historical trends in travel per vehicle continued throughout the 1972-1982 time period. (See Table 0.11.)

TABLE D.11. Predicted Vehicle Miles Traveled and Consumption 


\section{D.2.1.5 Reduction in Travel Speed}

Another explanatory component of the change in consumption which occurred in the past decade is the introduction of the $55 \mathrm{mph}$ speed limit approved by Congress and implemented in 1974.

An analysis by Mason and Zubb (1981) concluded that in 1979, the reduction in the national speed limit decreased fuel consumption by $112,000 \mathrm{~B} / \mathrm{D}$. For this analysis the fuel savings attributable to reduced speeds were estimated for each year assuming that the level of savings changed in direct proportion to the annual fluctuations in total vehicle miles traveled. Changes in speedlimit compliance are small and unaccounted for here (Mason and Zubb 1981).

\section{D.2.1.6 Summary}

Table 0.12 and Figure $D .2$ summarize the fuel savings attributable to changes in each of the factors influencing fuel use and efficiency in automobiles. In 1982, fuel consumption by automobiles is reduced by almost 32 percent (2.14 MMB/D) relative to that which would have occurred if historical trends in fuel use and efficiency established in the 1960s had continued in the 1970s. About 38 percent $(0.82 \mathrm{MMB} / \mathrm{D})$ of this reduction is attributable to the improvement in fleet average fuel economy via the expanded introduction of fuelefficient technologies in new cars. Curtailments in travel also have contributed a large portion of the fuel savings in the automobile sector. In 1982, for example, reduced travel accounted for 37 percent (0.80 MMB/D) of the total fuel savings.

The relative contribution of each of the components has shifted over time. As shown in $F$ igure 0.2 , changes in vehicle stock actually had a negative effect on fuel savings during the 1970s and turned positive only with the marked slowdown in fleet growth that occurred in the 1980s. In the early and mid-1970s, changes in travel accounted for the bulk of the savings achieved in the automobile sector. For example, in 1977, changes in travel contributed 53 percent of the total reduction whereas increases in mpg accounted for only 18 percent of the total. By 1981, however, the importance of travel reductions dropped in relation to that of increased fuel economy. (Travel reductions and 
TABLE D.12. Components of the Reduction in Automobile Fuel Use

$(M M B / D)$

\begin{tabular}{|c|c|c|c|c|c|c|}
\hline Year & ACT & MPGSAV & STKSAV & SIZSAV & SPOSAV & VMTSAV \\
\hline 1972 & 4.770 & 0.000 & 0.000 & 0.000 & 0.000 & 0.000 \\
\hline 1973 & 5.060 & -0.020 & -0.050 & 0.000 & 0.000 & -0.010 \\
\hline 1974 & 4.810 & -0.065 & -0.060 & 0.025 & 0.094 & 0.500 \\
\hline 1975 & 4.960 & -0.065 & -0.070 & 0.065 & 0.097 & 0.530 \\
\hline 1976 & 5.170 & 0.010 & -0.070 & 0.110 & 0.102 & 0.470 \\
\hline 1977 & 5.230 & 0.155 & -0.050 & 0.125 & 0.106 & 0.440 \\
\hline 1978 & 5.430 & 0.300 & -0.080 & 0.150 & 0.113 & 0.430 \\
\hline 1979 & 5.200 & 0.420 & -0.040 & 0.160 & 0.129 & 0.510 \\
\hline 1980 & 4.790 & 0.690 & 0.080 & 0.160 & 0.107 & 0.780 \\
\hline 1981 & 4.680 & 0.750 & 0.130 & 0.175 & 0.108 & 0.780 \\
\hline 1982 & 4.530 & 0.825 & 0.230 & 0.175 & 0.111 & 0.800 \\
\hline
\end{tabular}

ACT = Actual fuel consumption

MPGSAV = Fuel savings from increased fleet mpg resulting from technological improvements in new car design

SIKSAV = Fuel savings from reduced growth of the car fleet

SIZSAV = Fuel savings from reductions in vehicle size

SPDSAV = Fuel savings from reduced travel speeds

VMTSAV = Fuel savings attributable to changes in travel per car 


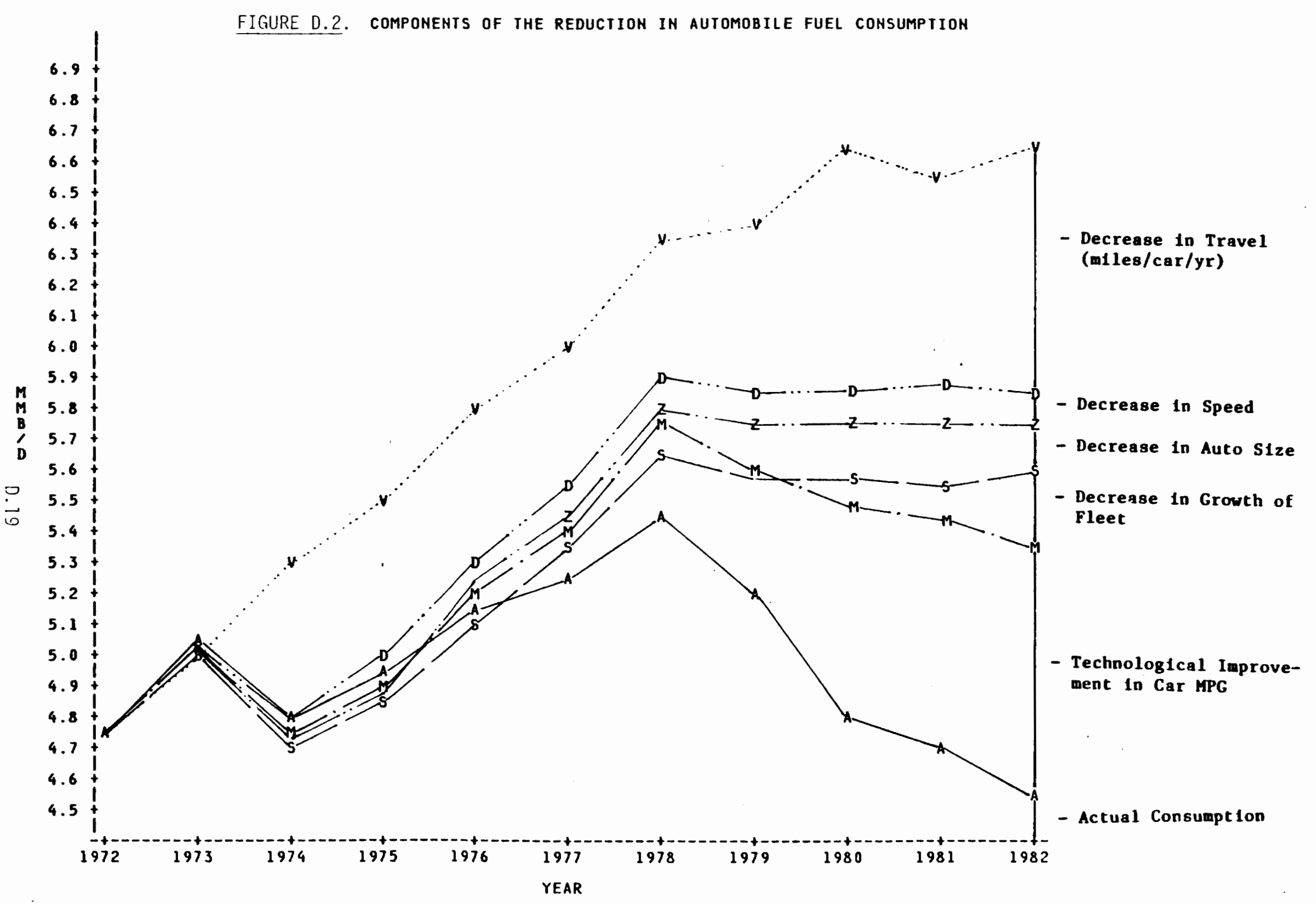


increased fuel economy accounted for 41 percent and 36 percent, respectively, of the total 1981 fuel savings.)

\section{D.2.2 Light-Duty Trucks ${ }^{3}$}

\section{D.2.2.1 Introduction}

As shown in Figure $D .3$ (and Table D.13), light-duty truck fuel consumption increased by almost 60 percent from $0.97 \mathrm{MMB} / \mathrm{D}$ in 1972 to $1.55 \mathrm{MMB} / \mathrm{D}$ in 1982 . A number of factors contributed to this trend. Perhaps first and foremost was the surge in the size of the light truck stock that occurred in the 1970s. Between 1972 and 1982, the light truck stock grew at over 7 percent per year-nearly double the 4 percent annual growth experienced in the 1968-1972 time period.

TABLE D.13. Actual Light Duty Truck Fuel Demand

\begin{tabular}{|c|c|c|c|c|}
\hline Year & $\begin{array}{c}\text { Vehicle Stock } \\
\left(\times 10^{5}\right) \\
\end{array}$ & $\begin{array}{l}\text { Fleet } \\
\text { MPG } \\
\end{array}$ & VMT/Light Truck & $\begin{array}{c}\text { Consumption } \\
(M M B / D) \\
\end{array}$ \\
\hline 1968 & 12.4 & 11.05 & 9,625 & 0.70 \\
\hline 1969 & 13.1 & 10.93 & 9,649 & 0.75 \\
\hline 1970 & 13.8 & 10.85 & 9,650 & 0.80 \\
\hline 1971 & 14.5 & 10.73 & 9,692 & 0.85 \\
\hline 1972 & 15.5 & 10.60 & 10,178 & 0.97 \\
\hline 1973 & 16.9 & 10.46 & 9,814 & 1.03 \\
\hline 1974 & 18.5 & 10.39 & 8,917 & 1.04 \\
\hline 1975 & 19.9 & 10.60 & 9,342 & 1.14 \\
\hline 1976 & 21.3 & 10.81 & 9,652 & 1.24 \\
\hline 1977 & 23.1 & 11.11 & 10,037 & 1.36 \\
\hline 1978 & 25.1 & 11.37 & 9,945 & 1.43 \\
\hline 1979 & 26.8 & 11.63 & 9,979 & 1.50 \\
\hline 1980 & 29.0 & 11.96 & 9,826 & 1.55 \\
\hline 1981 & 29.9 & 12.34 & 9,494 & 1.50 \\
\hline 198 & 30.6 & 12.80 & 9,473 & 1.48 \\
\hline
\end{tabular}

Source: 1968 to 1980 data drawn from Marino (1982).

1981 to 1982 data drawn from the DOE Highway Fuel Consumption model (EEA 1983).

3 All trucks and vans with a gross vehicle weight (GVW) less than 10,000 Ibs. 
FIGURE D.3. LIGHT DUITY IRUCK. FUEL CONSUMPTIÜN

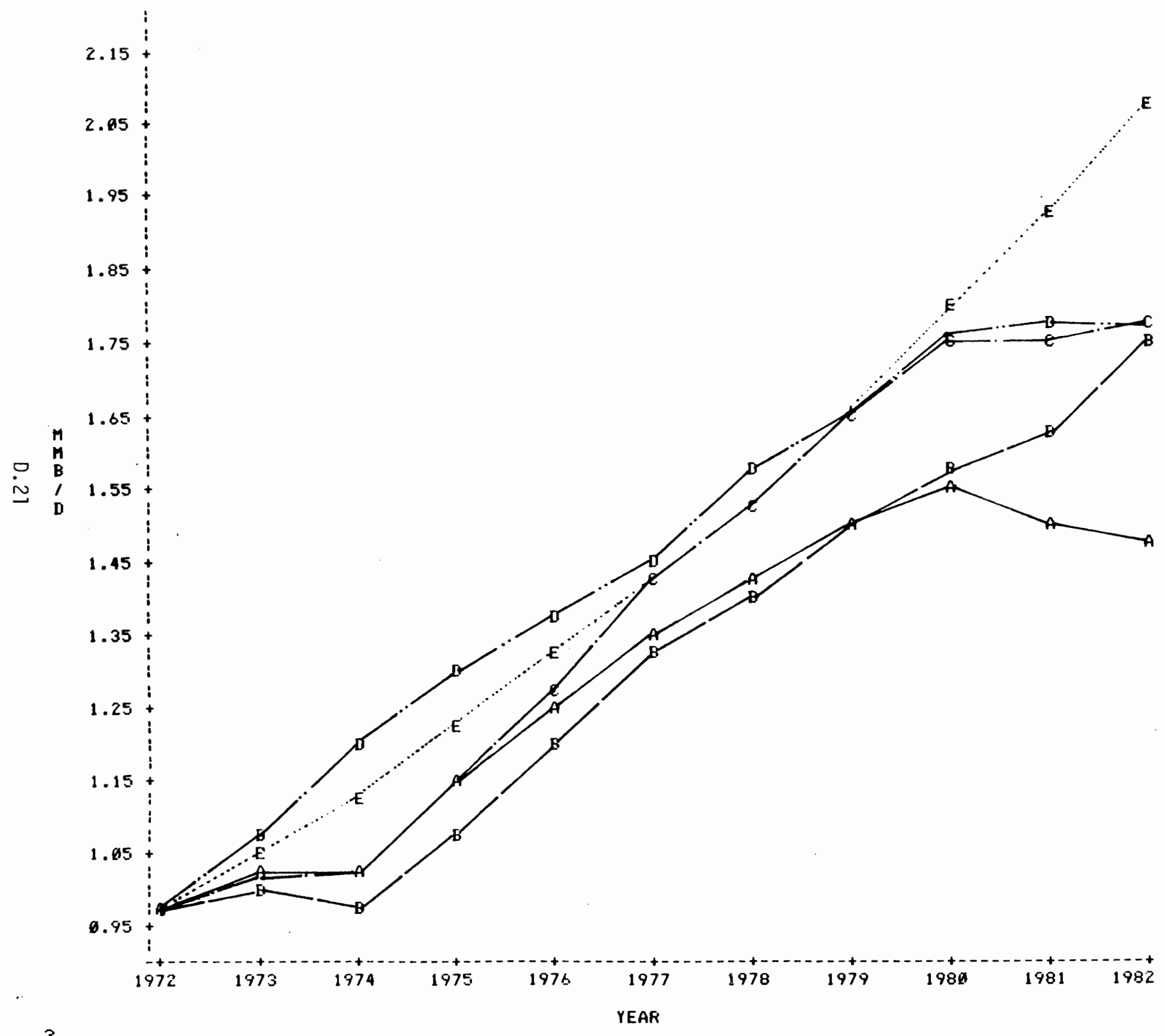


Other factors influencing light-duty truck fuel consumption include changes in the overall fleet fuel efficiency (miles per gallon) and activity level (average annual miles per truck). As illustrated in Figure 0.3 (and tabulated in Table 0.14), had average fleet fuel efficiency and activity continued to grow at the 1968 to 1972 annual rates of -1 percent and +1.5 percent, respectively, light-duty truck fuel consumption would have reached 2.08 MMB/D by 1982. Thus, in 1982, total gross fuel savings of $0.61 \mathrm{MMB} / \mathrm{D}$ may be attributed to increased growth in efficiency and reduced growth in travel relative to historical rates. (See Line $E$ minus Line $A$ in Figure 0.3 and Table D.15.) The reduction in travel alone produced savings of $0.29 \mathrm{MMB} / \mathrm{O}$ by 1982. (See Line D minus Line A.) The increase in the annual rate of growth in average fleet fuel efficiency (from -1 percent in the 1968-1972 period to +1.9 percent between 1972 and 1982) contributed fuel savings of 0.26 MMB/D by 1982 . (See Line B minus Line A.) Measured against the 1972 average light truck fleet fuel efficiency of $10.60 \mathrm{mpg}$ in 1972 , the total 20.7 percent improvement in overall fuel economy which occurred over the subsequent decade yielded total net energy savings of $0.31 \mathrm{MMB} / D$ in 1982 (Line $C$ minus Line $A$ in Figure 0.3 ).

TABLE D.14. Actual Light Duty Truck Fuel Use and Alternative Base Cases $(M M B / D)$

\begin{tabular}{lllllll} 
Year & $\mathrm{A}$ & $\mathrm{B}$ & $\mathrm{C}$ & $\mathrm{D}$ & $\mathrm{E}$ \\
\cline { 2 - 3 } 1972 & 0.97 & 0.97 & & 0.97 & 0.97 & 0.97 \\
1973 & 1.03 & 1.00 & 1.02 & 1.08 & 1.05 \\
1974 & 1.04 & 0.97 & 1.04 & 1.21 & 1.13 \\
1975 & 1.14 & 1.08 & 1.14 & 1.29 & 1.22 \\
1976 & 1.24 & 1.19 & 1.27 & 1.37 & 1.32 \\
1977 & 1.36 & 1.33 & 1.43 & 1.46 & 1.42 \\
1978 & 1.43 & 1.40 & 1.54 & 1.57 & 1.54 \\
1979 & 1.50 & 1.51 & 1.65 & 1.65 & 1.66 \\
1980 & 1.55 & 1.58 & 1.75 & 1.76 & 1.79 \\
1981 & 1.50 & 1.63 & 1.74 & 1.77 & 1.93 \\
1982 & 1.48 & 1.74 & 1.78 & 1.77 & 2.08
\end{tabular}

\footnotetext{
$A=$ Actual fuel use

$B=$ Trended fuel efficiency with actual activity growth

$C=$ Constant 1972 fuel efficiency with actual activity growth

$D=$ Actual fuel efficiency with trended activity growth

$E=$ Trended fuel efficiency with trended activity growth
} 
TABLE 0.15 . Estimates of Total Light Duty Truck Fuel Savings

$($ MMB $/ 0)$

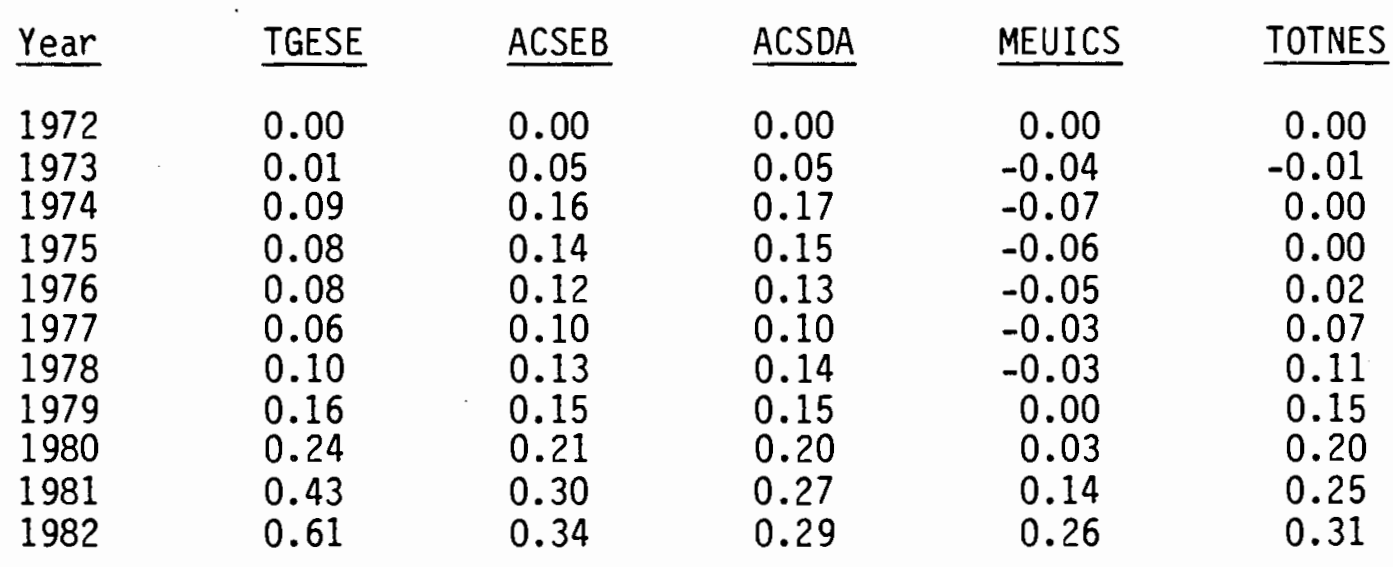

\footnotetext{
TGESE = Total gross fuel savings according to Line $E(E-A)$ $A C S D A=$ Activity change savings according to Lines $D$ and $A(D-A)$ ACSEB = Activity change savings according to Lines $E$ and $B(E-B)$ MEUICS = Marginal fuel efficiency change savings ( $B-A)$

TOTNES $=$ Total net fuel savings $(C-A)$
}

As in the automobile sector, factors such as changes in vehicle use and maintenance, the implementation of fuel-efficient technologies in new light trucks, and shifts in the mix of light trucks sold have all contributed to the total net fuel savings achieved in this transportation subsector since 1972 . In the discussion that follows, the contribution of each of these components to the total net energy saved is examined. In addition, the fuel consumption impacts of the growth in the truck stock and changes in activity over the 19721982 period also are presented in order to place the savings attributable to fuel efficiency in context. The analysis replicates the methodology and data used in a recent DOE-sponsored study that evaluated trends in the fuel use and efficiency of light trucks in the 1972-1980 time period (Marino 1982). For the purpose of brevity, therefore, the discussion of the methodology will not be repeated here. 


\section{D.2.2.2 Components of Fuel Efficiency in Light Trucks}

As indicated above, three major factors influencing fuel efficiency in light trucks were identified. These are:

o improved vehicle maintenance and operation

- effects of shifts in the mix of new light truck sales by size class

o impact of technology improvements.

A separate analys is sponsored by the Department of Energy attempted to measure the impact of improved maintenance and operation of light trucks on fuel consumption (EEA 1982b). The study was based on an examination of data from the National Family Opinion (NF0) poll gasoline diary data base for 1978 to 1980. The examination concluded that no improvement in fuel economy could be identified that was attributable to improved maintenance or operation over that period of time.

As with automobiles, the fuel economy of light trucks varies in proportion to vehicle weight. Light trucks range in weight up to about 10,000 1bs GVW. Therefore, shifts in the mix of trucks in use by size or weight have a significant impact on average fuel economy. The HFC model separately tracks the fuel economies and market shares of three weight categories of 1 ight trucks for the period 1975 to $1982 .{ }^{4}$ It was therefore used to evaluate the effect of the shift in mix which occurred in that time period. The results are shown in Table D.16.

Between 1975 and 1982 the fraction of the total light duty truck fleet that was over 6000 lbs GVW rose from 27.1 percent to 43.7 percent. Over the same time period, the fraction of total light trucks not subject to the corporate average fuel economy standards (these are trucks in the Class $2 \mathrm{~b}$ category) rose from 2.7 percent to 6.8 percent. As a result of this shift towards heavier, less-efficient light duty trucks, fuel savings due to changes

4 These categories include: Class 1 domestic and foreign light trucks $(0-$ 6,000 lbs GVW); Class 2 a light trucks $(6,001-8,500$ lbs GVW); and Class $2 \mathrm{~b}$ light trucks $(8,501-10,000$ lbs GVW). The analysis begins with 1975 because that is the first year of output available from the HFC model. 
TABLE D.16. Analysis of Light Truck Market

Size Mix Shift: 1975-1982

Light Truck Fleet On-Road Fue 1 Economy (MPG)

\begin{tabular}{lll}
\multicolumn{3}{c}{ Fuel Economy (MPG) } \\
Year Actual No Mix \\
Mix Shift Change
\end{tabular}

$1972 \quad \mathrm{~N} / \mathrm{A} \quad \mathrm{N} / \mathrm{A} \quad \mathrm{N} / \mathrm{A}$

$1973 \quad N / A \quad N / A \quad N / A$

1974

1975

1976

1977

1978

1979

1980

1981

1982
$\mathrm{N} / \mathrm{A}$

9.48

9.73

9.86

10.00

10.20

10.48

10.81

11.21

$\mathrm{N} / \mathrm{A} \quad \mathrm{N} / \mathrm{A}$

$9.53-0.05$

$9.86-0.13$

$10.07 \quad-0.21$

$10.31 \quad-0.31$

$10.54 \quad-0.34$

11.16

11.58

$-0.35$

$-0.37$
$10.81 \quad-0.33$
Light Truck Fuel Consumption (MMB/D)

\begin{tabular}{|c|c|}
\hline $\begin{array}{l}\text { Actual } \\
\text { Mix }\end{array}$ & $\begin{array}{l}\text { No Mix } \\
\text { Shift }\end{array}$ \\
\hline
\end{tabular}

$\begin{array}{lrr}\text { N/A } & \text { N/A } & \text { N/A } \\ \text { N/A } & \text { N/A } & \text { N/A } \\ \text { N/A } & \text { N/A } & \text { N/A } \\ 1.39 & 1.38 & -0.01 \\ 1.56 & 1.53 & -0.03 \\ 1.68 & 1.64 & -0.04 \\ 1.80 & 1.74 & -0.06 \\ 1.88 & 1.80 & -0.08 \\ 1.88 & 1.81 & -0.07 \\ 1.84 & 1.78 & -0.06 \\ 1.80 & 1.73 & -0.07\end{array}$

Source: U.S. Department of Energy, "Highway Fuel Consumption Mode 1." 
in mix were negative throughout the 1972-1982 time period (on the order of $-0.07 \mathrm{MMB} / \mathrm{D}$ by 1982 )

The results of the preceding analyses are summarized in Table 0.17. It is assumed that all fuel savings not accounted for by shifts in vehicle size mix and operation and maintenance improvements (none) are the direct result of the introduction of improved fuel-efficient technologies in new light trucks. As shown in Table 0.17 , fuel savings due to technology improvements have increased significantly since the introduction of corporate average fuel economy standards for light trucks less than 8500 lbs GVW in 1979. Between 1978 and 1982, fuel savings from the introduction of fuel-efficient technology rose from $0.17 \mathrm{MMB} / \mathrm{D}$ to $0.38 \mathrm{MMB} / \mathrm{D}$. Although shifts in the mix of light trucks in use in the mid-1970s negated much of the savings due to technology by 1982 , technological improvements yielded conservation benefits that far outweighed (by a factor of 5) the effects of increased use of larger, heavier vehicles.

TABLE 0.17. Components of Total Net Fuel Savings in the Light Truck Sector

$(M M B / D)$

\begin{tabular}{lccr} 
Year & $\begin{array}{c}\text { Total Net } \\
\text { Fuel Savings }\end{array}$ & $\begin{array}{c}\text { Technology } \\
\text { Improvements }\end{array}$ & $\begin{array}{r}\text { Mix } \\
\text { Shift }\end{array}$ \\
\cline { 2 - 4 } 1972 & 0.00 & N/A & N/A \\
1973 & -0.01 & N/A & N/A \\
1974 & 0.00 & N/A & N/A \\
1975 & 0.00 & 0.01 & -0.01 \\
1976 & 0.02 & 0.05 & -0.03 \\
1977 & 0.07 & 0.11 & -0.04 \\
1978 & 0.11 & 0.17 & -0.06 \\
1979 & 0.15 & 0.23 & -0.08 \\
1980 & 0.20 & 0.27 & -0.07 \\
1981 & 0.25 & 0.31 & -0.06 \\
1982 & 0.31 & 0.38 & -0.07
\end{tabular}

\section{D.2.2.3 Vehicle Stock}

Data for fleet registrations of light trucks were drawn from Marino (1982) and were updated to include statistics for 1981 and 1982 . The data series was listed previously in Table D.13. A log-linear regression equation had been 
developed by Marino (1982) to quantify the historical growth in light truck registrations over the 1968-1972 time period. This equation was used to estimate what fleet registrations would have been in the 1972-1982 time period assuming continuation of the historical (1968 to 1972) growth trend. Using the actual data on VMT/vehicle and fleet mpg for 1972 to 1982 (from Table D.13), the resultant fuel savings from changes in the growth of the vehicle stock were calculated. (See Table D.18.) Due to the fact that the actual annual growth in fleet registrations over the period 1972 to 1982 was 7 percent, or nearly double the 4 percent yearly growth observed prior to 1972, fuel savings from this component have been strongly negative.

TABLE D.18. Components of the Reduction in LDT Fuel Use $(M M B / D)$

$\begin{array}{lllllll}\text { Year } & \text { ACT } & \text { MIXSAV } & \text { REGSAV } & \text { TECHSAV } & \text { SPDSAV } & \text { VMTSAV } \\ 1972 & 0.970 & 0.000 & 0.000 & 0.000 & 0.000 & 0.000 \\ 1973 & 1.030 & 0.000 & -0.030 & 0.000 & 0.000 & 0.050 \\ 1974 & 1.040 & 0.000 & -0.070 & 0.000 & 0.000 & 0.170 \\ 1975 & 1.140 & -0.010 & -0.090 & 0.040 & 0.015 & 0.150 \\ 1976 & 1.240 & -0.030 & -0.120 & 0.080 & 0.017 & 0.130 \\ 1977 & 1.360 & -0.040 & -0.160 & 0.140 & 0.019 & 0.100 \\ 1978 & 1.430 & -0.060 & -0.200 & 0.200 & 0.021 & 0.140 \\ 1979 & 1.500 & -0.080 & -0.230 & 0.270 & 0.029 & 0.150 \\ 1980 & 1.550 & -0.070 & -0.260 & 0.350 & 0.023 & 0.210 \\ 1981 & 1.500 & -0.060 & -0.230 & 0.410 & 0.023 & 0.270 \\ 1982 & 1.480 & -0.070 & -0.190 & 0.490 & 0.024 & 0.290\end{array}$

ACT = Actual fuel use

MIXSAV = Fuel savings due to shifts in the mix of LDTs in-use REGSAV = Fuel savings from changes in the growth of the fleet TECHSAV = Fuel savings from improved new vehicle $\mathrm{mpg}$ SPDSAV = Fuel savings from decreases in speeds VMTSAV = Fuel savings from reduced average annual travel per LDT

\section{D.2.2.4 VTM/Vehicle}

As with the fleet registrations, the data on VMT/vehicle for light trucks also were drawn from Marino (1982) and were updated to include statistics for 1981 and 1982. (See Table D.13.) Using the log-linear regression developed by 
Marino (1982) to quantify the historical growth in travel per vehicle, estimates of what annual VMT/light truck would have been had the 1968-1972 trend continued through 1982 were calculated. These estimates, in turn, were used in conjunction with 1972-1982 actual statistics on fleet registrations and fleet mpg to quantify the fuel savings attributable to changes in the growth of travel per light truck. The results are listed in Table 0.18. Fuel savings due to the curtailment of travel below historical rates of growth are strongly positive, particularly in the 1980s when the absolute level of annual VMT/light truck actually dropped 3.6 percent (from 1980 to 1982 ).

\section{D.2.2.5 Changes in Vehicle Speeds}

The reduction of travel speed mandated by the national 55 mph statute established in 1974 had an impact on fuel consumption similar to that for the automobile sector. This component was calculated using the estimate (derived from Mason and Zubb 1981) of total fuel savings of 22,000 B/D attributable to compliance by 40 percent of the light truck fleet with the $55 \mathrm{mph}$ speed limit in 1979. The ratios of total VMT for 1974 through 1982 to the VMT for 1979 were used to adjust this estimate to yield fuel savings attributable to changes in speed for the entire time period under analysis. The results are shown in Table 0.18 .

\section{D.2.2.6 Summary}

Figure D.4 summarizes the fuel savings attributable to changes in each of the factors influencing fuel use and efficiency in light trucks. Technological improvements have had the most significant impact on conservation in light trucks--accounting for about 55 percent $(0.38 \mathrm{MMB} / 0)$ of the total reduction in 1982 shown in Figure D.4. Decreases in travel per vehicle contributed about 42 percent of the total net savings in this sector in 1982 while reductions in speed accounted for the remaining 3 percent.

As shown in Figure 0.4 , a major factor influencing fuel conservation in the light truck sector has been the tremendous growth in registrations and shift towards larger, heavier vehicles which occurred in the 1970s. By 1982 , 


\section{FIGURE 0.4 .}

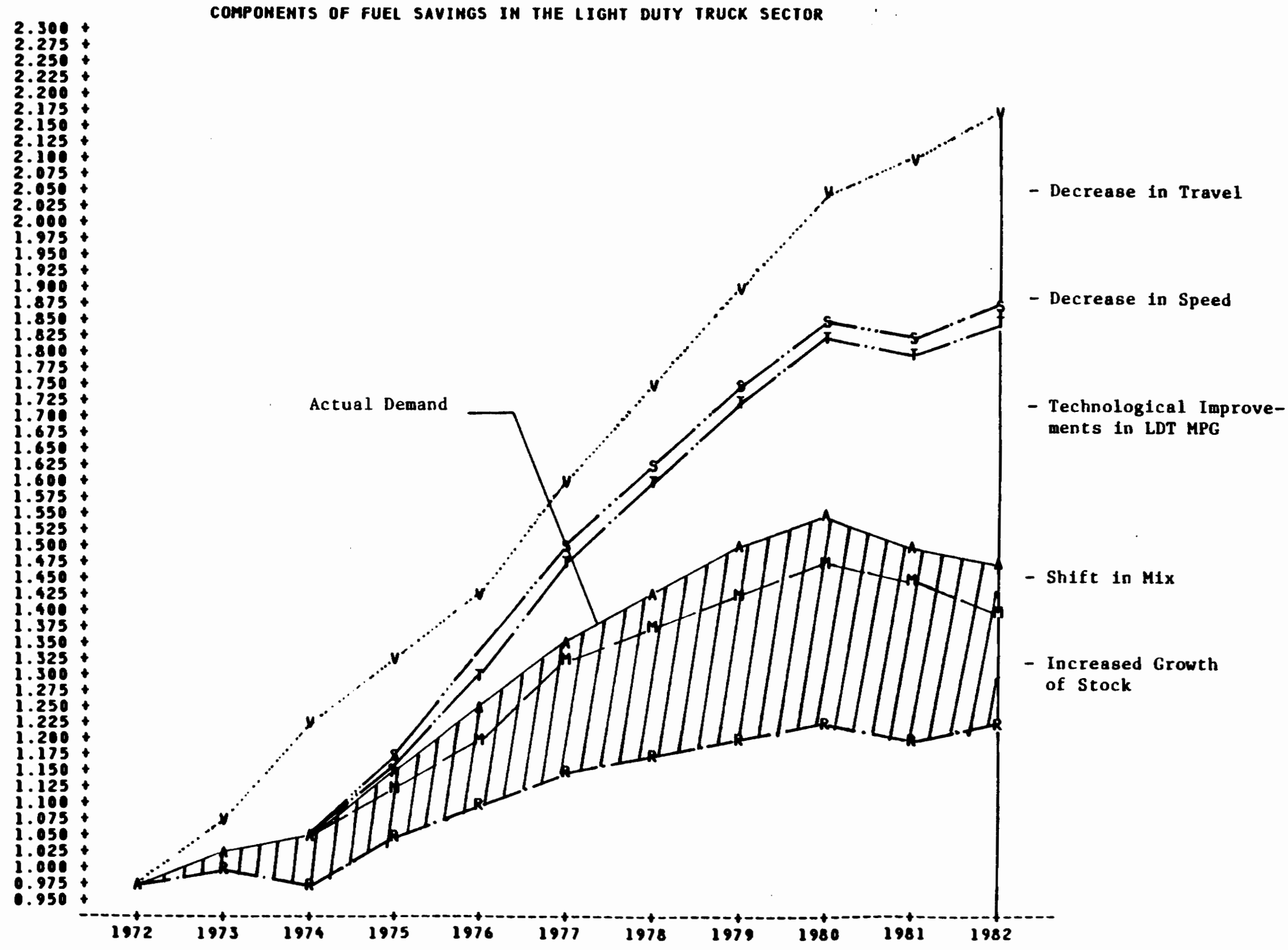


this surge in registrations (over and above historical rates of growth) yielded negative fuel savings of $-0.19 \mathrm{MMB} / \mathrm{D}$, and the shift in mix also produced negative savings of $-0.07 \mathrm{MMB} / 0$ in that year. These two components together almost completely offset the $0.29 \mathrm{MMB} / D$ of fuel savings attributable to reduced growth in travel per vehicle in 1982 .

\section{D.2.3 Commercial Trucks}

An earlier study for the U.S. Department of Energy evaluated trends in fuel demand and fuel efficiency in the commercial trucking industry (EEA 1982a). That study examined total fuel savings over the 1967-1980 time period relative to a baseline in which commercial truck fuel efficiency was held constant at 1967 levels. Severe data limitations and inconsistencies prevented the disaggregation and quantification of the individual components influencing commercial truck fuel efficiency and fuel use.

Therefore, the current effort has focused on the use of the aggregate data from the earlier work to develop the five generic estimates of fuel demand in the 1972-1982 time period under alternative assumptions, regarding trends in fuel efficiency (ton-miles per gallon) and activity (total ton-miles of travel or TMT).

\section{D.2.3.1 Results}

Figure $D .5$ and Table $D .19$ present trends in actual commercial truck fuel consumption (Line A) and estimates of what fuel demand would have been had fuel efficiency and/or activity remained constant at 1972 levels or continued to grow at historical (1967 to 1972) rates in the 1972-1982 time period (Lines B, $C, D$, and $E)$. Actual fuel use in the commercial trucking sector increased by almost 45 percent from $0.56 \mathrm{MMB} / \mathrm{D}$ in 1972 to a peak of $0.81 \mathrm{MMB} / \mathrm{D}$ in 1978 , primarily as a result of the rapid expansion of the truck stock and activity in the early and mid-1970s. (See Figure D.6.) The commercial trucking sector has achieved very little fuel conservation in the past 10 years. In fact, as shown by the difference between Line $E$ and Line $A$ in Figure $D .5$, commercial truck fuel consumption grew at a higher annual rate during much of the $1970 \mathrm{~s}$ than in the 1960s. As a result, total gross energy savings between 1976 and 1979 ranged from $-0.03 \mathrm{MMB} / \mathrm{D}$ to $-0.07 \mathrm{MMB} / \mathrm{D}$. (See Table D.20.) 


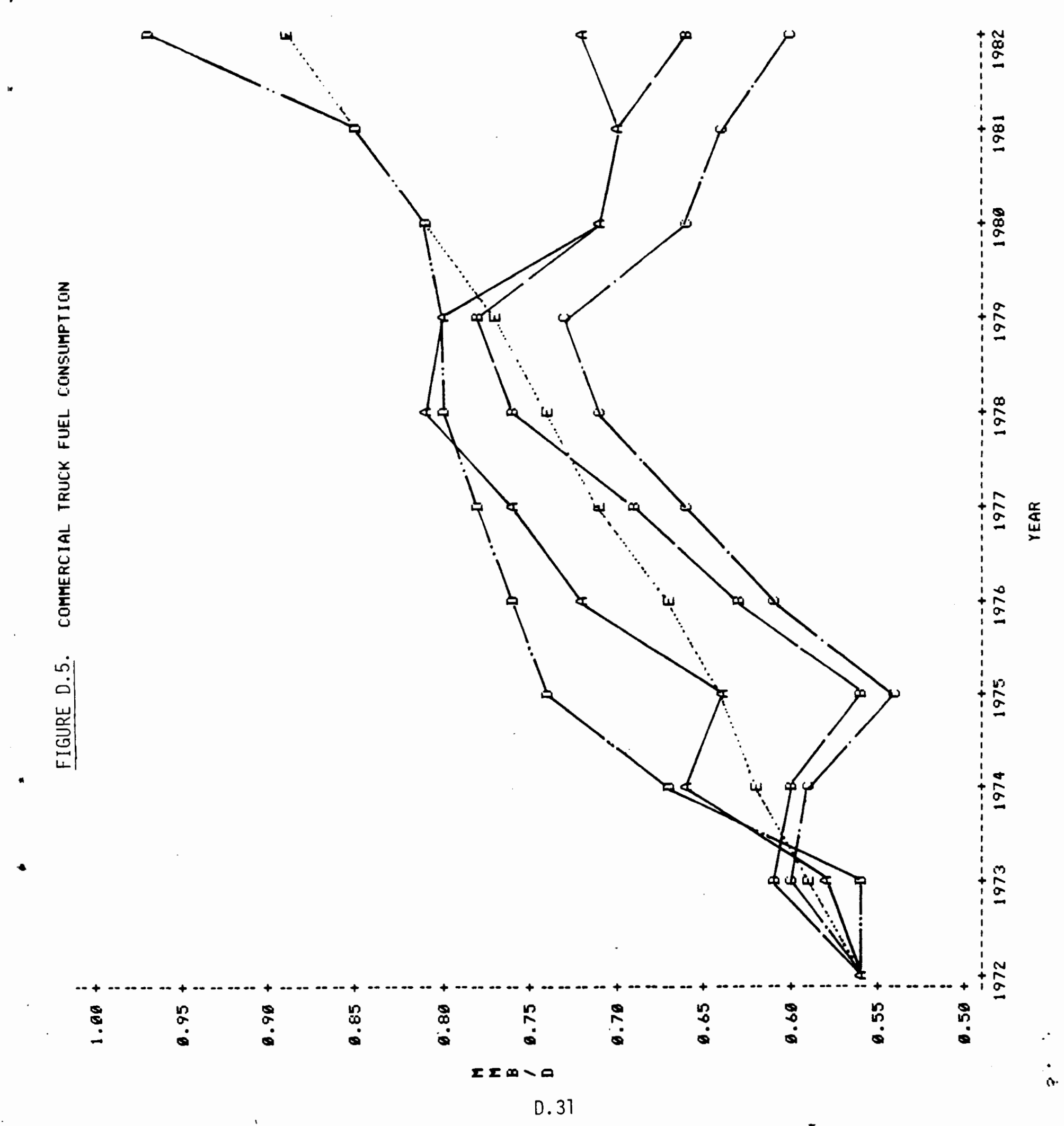


TABLE D.19. Actual Commercial Truck Fuel Use and Alternative Base Cases (MMB/D)

\begin{tabular}{llllll} 
Year & $\mathrm{A}$ & $\mathrm{B}$ & $\mathrm{C}$ & $\mathrm{D}$ & $\mathrm{E}$ \\
\cline { 2 - 2 } 1972 & 0.56 & 0.56 & 0.56 & 0.56 & 0.56 \\
1973 & 0.58 & 0.61 & 0.60 & 0.56 & 0.59 \\
1974 & 0.66 & 0.60 & 0.59 & 0.67 & 0.62 \\
1975 & 0.64 & 0.56 & 0.54 & 0.74 & 0.64 \\
1976 & 0.72 & 0.63 & 0.61 & 0.76 & 0.67 \\
1977 & 0.76 & 0.69 & 0.66 & 0.78 & 0.71 \\
1978 & 0.81 & 0.76 & 0.71 & 0.80 & 0.74 \\
1979 & 0.80 & 0.78 & 0.73 & 0.80 & 0.77 \\
1980 & 0.71 & 0.71 & 0.66 & 0.81 & 0.81 \\
1981 & 0.70 & 0.70 & 0.64 & 0.85 & 0.85 \\
1982 & 0.72 & 0.66 & 0.60 & 0.97 & 0.89
\end{tabular}

$A=$ Actual energy use

$B=$ Trended EUI with actual activity growth

$C=$ Constant 1972 EUI with actual activity growth

$D=$ Actual EUI with trended activity growth

$E=$ Trended EUI with trended activity growth

Reductions in fuel use appear to have been largely due to sharp declines in activity during periods of economic recession rather than to significant changes in the technological and operating efficiency of the fleet. For example, had historical (1968 to 1972) trends in the growth of ton-miles of travel continued throughout the 1970s, fuel consumption in 1982 would have been 0.97 MMB/D by 1982 (Line $D$ in Figure D.5). However, between 1979 and 1982, total activity dropped by 17.4 percent. This reduction contributed to fue 1 savings of $0.25 \mathrm{MMB} / D$ in 1982 (Line $D$ minus Line $A$ in Figure 0.5 and Table 0.20). Even with respect to the historical trend in fuel efficiency (which declined at a modest rate of 0.1 percent per year), there has been no marginal improvement in the 1972-1982 time period. In fact, fuel efficiency declined at an even faster rate of over 1 percent per year between 1972 and 1982--yielding negative fuel savings of $-0.06 \mathrm{MMB} / \mathrm{D}$ by 1982 ( $L$ ine $B$ minus Line $A$ in Figure D.5 and Table D.20). 


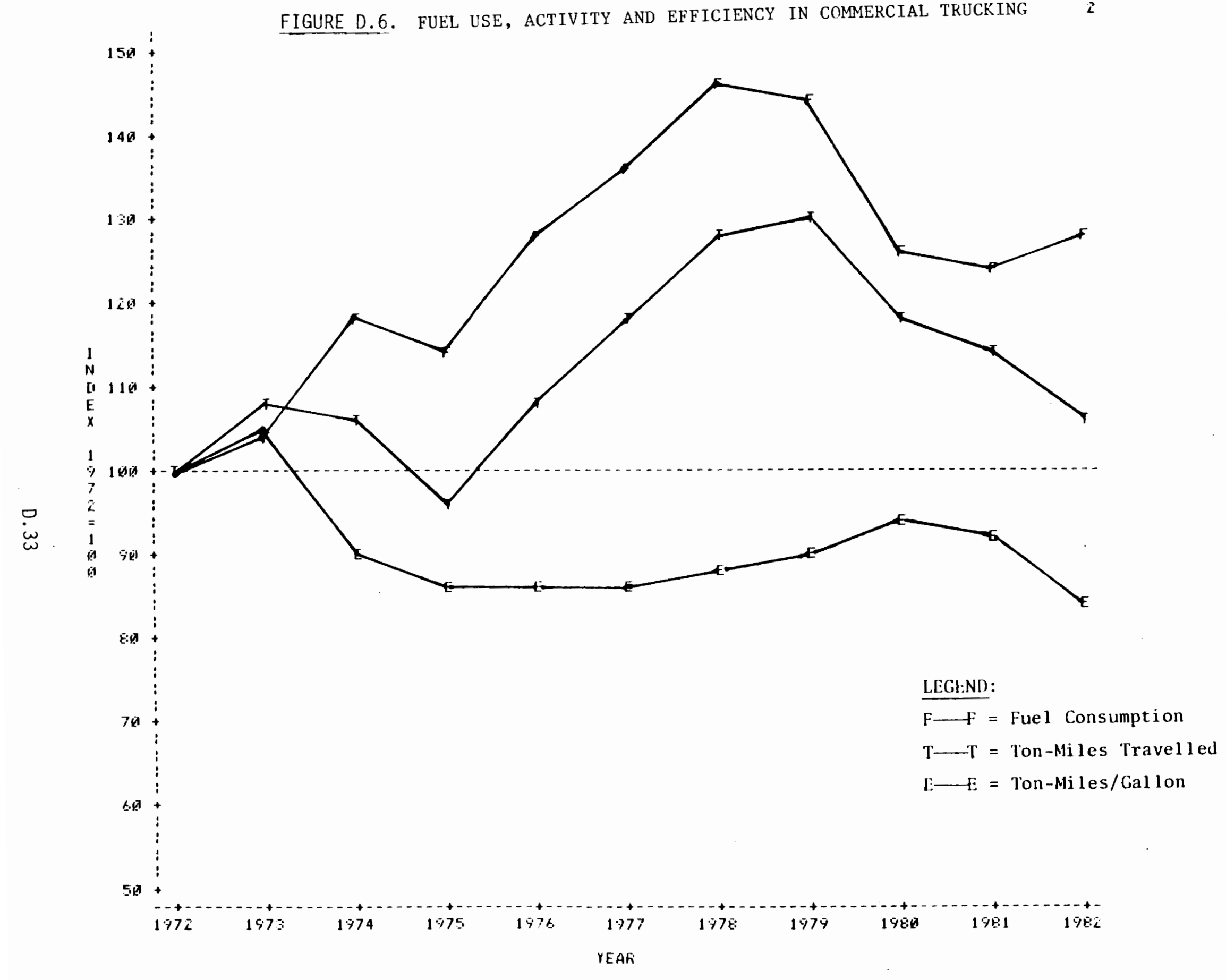


TABLE D.20. Alternative Estimates of Commercial Truck Fuel Savings (MMB/D)

\begin{tabular}{lrrrrr} 
Year & TGESE & ACSDA & ACSEB & MEUICS & TOTNES \\
\hline 1972 & 0.00 & 0.00 & 0.00 & 0.00 & 0.00 \\
1973 & 0.01 & -0.02 & -0.02 & 0.03 & 0.02 \\
1974 & -0.04 & 0.01 & 0.01 & -0.06 & -0.07 \\
1975 & 0.01 & 0.10 & 0.09 & -0.08 & -0.10 \\
1976 & -0.04 & 0.05 & 0.04 & -0.08 & -0.11 \\
1977 & -0.06 & 0.01 & 0.01 & -0.07 & -0.10 \\
1978 & -0.07 & -0.02 & -0.02 & -0.06 & -0.10 \\
1979 & -0.03 & -0.00 & -0.00 & -0.03 & -0.08 \\
1980 & 0.10 & 0.10 & 0.10 & 0.00 & -0.05 \\
1981 & 0.15 & 0.15 & 0.15 & 0.00 & -0.06 \\
1982 & 0.18 & 0.25 & 0.23 & -0.06 & -0.12
\end{tabular}

\footnotetext{
TGESE = Total gross fuel savings according to Line $E$ (E-A) $A C S D A=$ Activity change savings according to Lines $D$ and $A(D-A)$ $A C S E B=$ Activity change savings according to Lines $E$ and $B(E-B)$ MEUICS = Marginal fuel efficiency change savings (B-A)

TOTNES = Total net fuel savings $(C-A)$
} 


\section{D.3 COMMERCIAL AIRLINES}

\section{D.3.1 Introduction}

Between 1967 and 1972, fuel consumed by commercial airlines rose 44 percent while the level of service (measured in revenue-passenger miles) provided by the industry increased 62 percent. From 1972 to 1979, service grew an additional 60 percent, although fuel demand rose only 8 percent. Although service subsequently fell 3 percent over the 1979-1982 period, fuel consumption dropped by an even larger amount--9 percent--over the same time period. In short, the rate of improvement in the efficiency with which service was delivered after the Arab oil embargo of 1973 appears to have accelerated in comparison to the trend in existence in the pre-embargo time frame.

In recent papers prepared for the Department of Energy, trends in fuel use and efficiency in the U.S. commercial airline industry were analyzed for the 1973-1980 time period and the 1967-1980 time period (EEA 1982a, Smith 1981). Those studies employed identical methodologies to disaggregate the components of fuel efficiency. Data on aircraft operating performance were obtained from the Civil Aeronautics Board (CAB) and covered the entire U.S. commercial fleet excluding those aircraft employed in helicopter service, all-cargo service and commuter service.

The purpose of this analysis is to update the earlier studies to include 1981 and 1982 CAB data and to use 1972 as the base year in order to remain consistent with the other transportation subsectors examined. In the following discussion, the overall trends in commercial airline fuel consumption, activity, and fuel efficiency are briefly reviewed. A detailed assessment of the components of commercial aircraft fuel efficiency improvements is then presented.

\section{D.3.2 Overall Trends in Commercial Airline Fuel Consumption}

Fuel consumed by commercial airlines rose 8.4 percent from $0.62 \mathrm{MMB} / \mathrm{D}$ in 1972 to $0.67 \mathrm{MMB} / \mathrm{D}$ in 1979. Over the same time period, the average efficiency of the fleet of commercial aircraft increased 47.5 percent from 16.9 revenue passenger miles per gallon (RPM/G) to $24.9 \mathrm{RPM} / \mathrm{G}$. Fuel demand subsequently 
dropped in the 1980 s to $0.611 \mathrm{MMB} / \mathrm{D}$ by $1982--$ primarily as a result of the effect of economic recession on declining traffic levels or revenue passenger miles. (See Figure D.7, Tables D.21 and D.22.) Nevertheless, the fuel efficiency of the fleet continued to rise an additional 6.8 percent to reach $26.7 \mathrm{RPM} / \mathrm{G}$ by 1982 .

\section{TABLE D.21. Actual U.S. Commercial Airline Fuel} Use and Alternative Base Cases

(MMB/D)

\begin{tabular}{lllllll} 
Year & $\mathrm{A}$ & $\mathrm{B}$ & $\mathrm{C}$ & $\mathrm{D}$ & $\mathrm{E}$ \\
\cline { 2 - 3 } 1972 & 0.622 & 0.622 & 0.622 & 0.622 & 0.622 \\
1973 & 0.623 & 0.623 & 0.636 & 0.651 & 0.650 \\
1974 & 0.567 & 0.616 & 0.642 & 0.624 & 0.679 \\
1975 & 0.565 & 0.604 & 0.641 & 0.660 & 0.705 \\
1976 & 0.590 & 0.657 & 0.712 & 0.656 & 0.730 \\
1977 & 0.620 & 0.695 & 0.766 & 0.673 & 0.754 \\
1978 & 0.637 & 0.791 & 0.889 & 0.627 & 0.778 \\
1979 & 0.674 & 0.868 & 0.993 & 0.622 & 0.801 \\
1980 & 0.647 & 0.810 & 0.944 & 0.658 & 0.823 \\
1981 & 0.616 & 0.769 & 0.912 & 0.676 & 0.844 \\
1982 & 0.611 & 0.797 & 0.963 & 0.662 & 0.864
\end{tabular}

\footnotetext{
$A=$ Actual fuel use

$B=$ Trended fuel efficiency with actual activity growth

$C=$ Constant 1972 fuel efficiency with actual activity growth

$D=$ Actual fuel efficiency with trended activity growth

$E=$ Trended fuel efficiency with trended activity growth
}

Had historical (1967 to 1972) trends in the annual growth of commercial aircraft fuel consumption continued in the 1972-1982 time period, fuel use would have reached $0.86 \mathrm{MMB} / \mathrm{D}$ by 1982 . Thus, the combined effects of reductions in the growth of activity and improvements in overall efficiency relative to historical trends reduced 1982 fuel consumption by 29.2 percent for a total gross fuel savings of $0.25 \mathrm{MMB} / \mathrm{D}$. (See Line $E$ minus Line $A$ in Figure D.7 and Table D.23.) 
TABLE D.22. Actual and Trended Fuel Efficiency and Activity in the U.S. Commercial Aircraft Sector

\begin{tabular}{llllll} 
& \multicolumn{2}{c}{ Actual } & & \multicolumn{2}{c}{ Trended } \\
\cline { 2 - 3 } Year & RPM/G & TRPM & & RPM/G & TRPM \\
1972 & 16.92 & 1613 & 16.92 & 1613 \\
1973 & 17.26 & 1650 & 17.27 & 1722 \\
1974 & 19.15 & 1664 & 17.61 & 1832 \\
1975 & 19.19 & 1663 & 17.97 & 1941 \\
1976 & 20.39 & 1845 & 18.32 & 2050 \\
1977 & 20.93 & 1988 & 18.67 & 2159 \\
1978 & 23.62 & 2306 & 19.02 & 2269 \\
1979 & 24.95 & 2576 & 19.37 & 2378 \\
1980 & 24.67 & 2449 & 19.72 & 2487 \\
1981 & 25.05 & 2366 & 20.08 & 2597 \\
1982 & 26.66 & 2497 & 20.43 & 2706
\end{tabular}

RPM/G = Revenue passenger miles per gallon

TRPM $=$ Total revenue passenger miles $(x 100,000)$

Source: Actual data derived from Civil Aeronautics Board (CAB) statistics

Trended data derived from an extrapolation of 1967 . 1972 growth rates 
FIGURE D.7. FUEL USE IN THE U.S. COMMERCIAL AIRLINES INDUSTRY

$\dot{\omega}_{\infty}^{\square}$

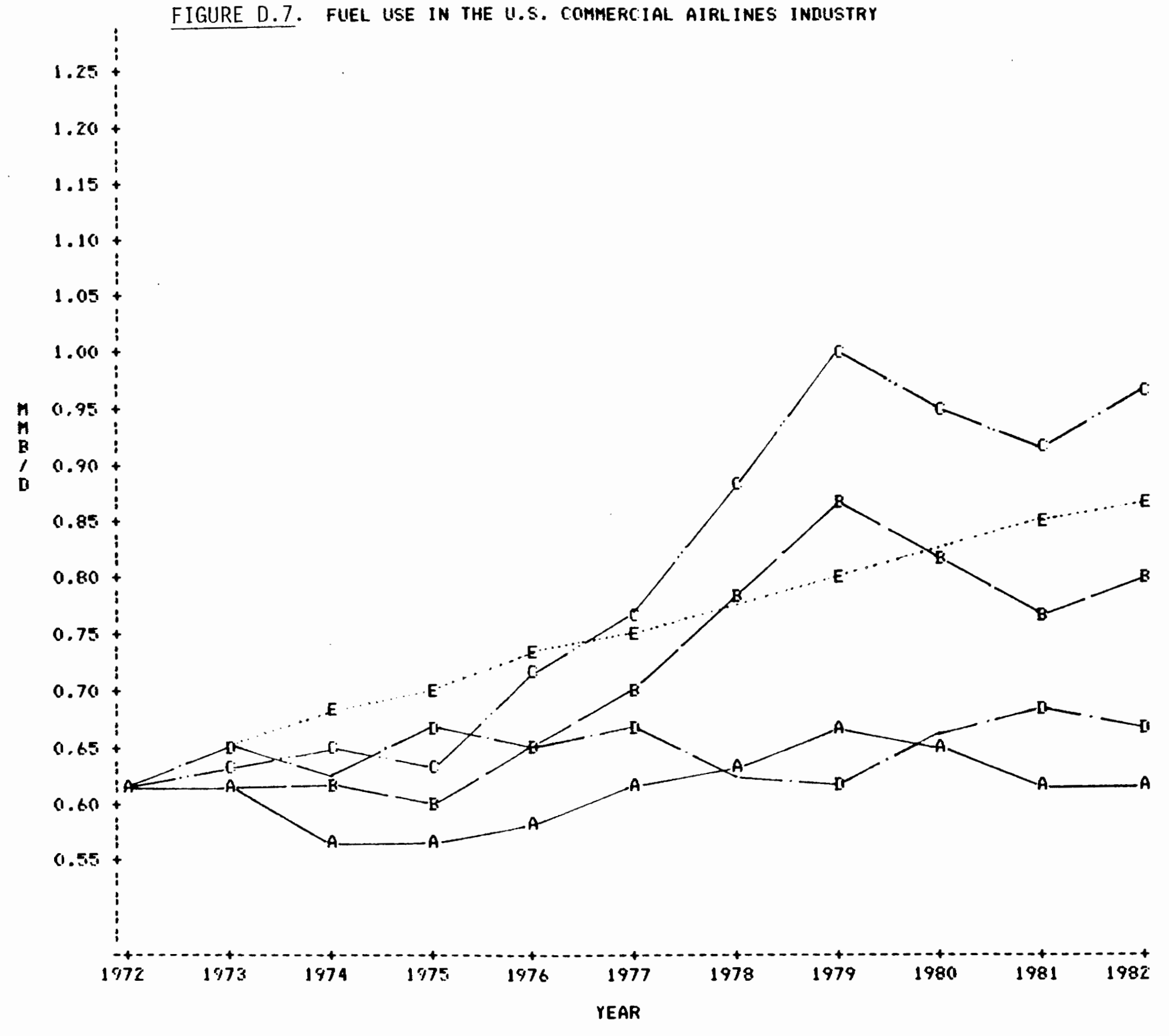


TABLE D.23. Alternative Estimates of Fuel Savings in the U.S. Commercial Airline Industry

(MMB/D)

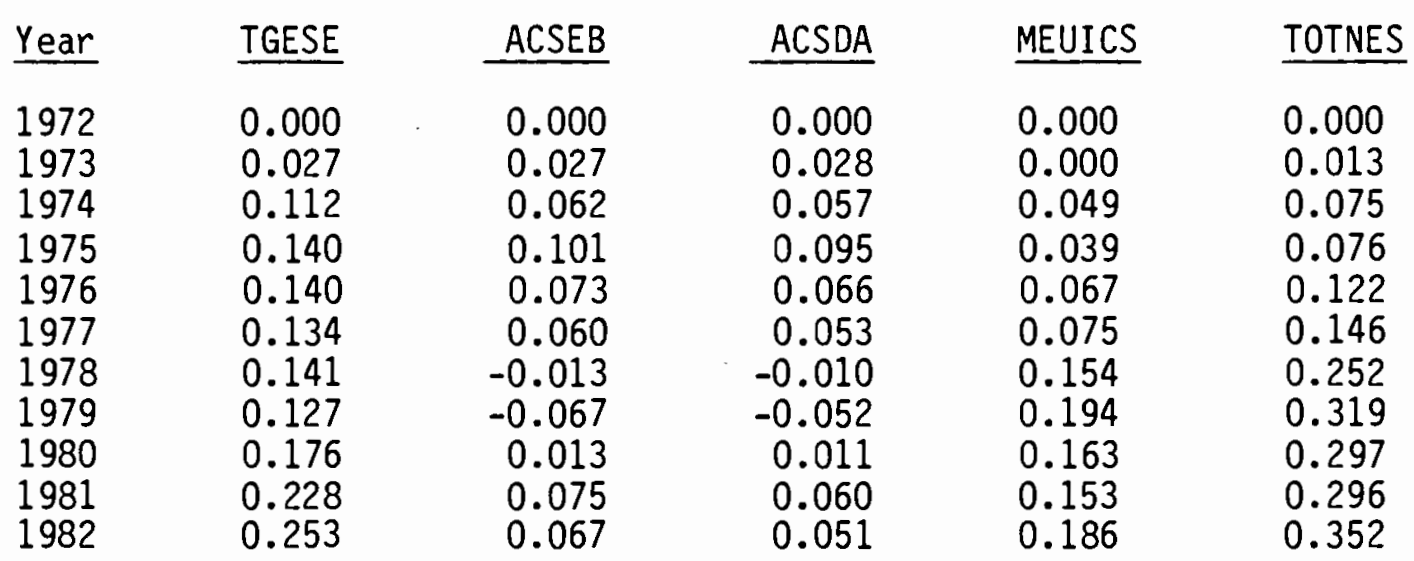

\footnotetext{
TGESE = Total gross fuel savings according to Line $E(E-A)$ $A C S D A=$ Activity change savings according to Lines $D$ and $A(D-A)$ $A C S E B=$ Activity change savings according to Lines $E$ and $B(E-B)$ MEUICS = Marginal EUI change savings $(B-A)$

TOTNES $=$ Total net fuel savings $(C-A)$
}

Figure $D .7$ also separates the impacts of the overall changes in activity vs. efficiency on commercial aircraft fuel use. Between 1967 and 1972, total revenue passenger miles grew at an average annual rate of 10 percent per year. Over the ensuing 10 years this growth rate dropped to about 4.5 percent per year. Had activity grown at the historical rate with efficiency improvements occurring at the actual rates, fuel consumption would have reached $0.66 \mathrm{MMB} / \mathrm{D}$ in 1982. (See Line $D$ in Figure 0.7 and Table D.21.) Hence changes in the growth of activity produced a 7.7 percent (or $0.051 \mathrm{MMB} / \mathrm{D}$ ) reduction in fuel use by 1982 (Line $D$ minus Line $A$ in Figure 0.7 and Table 0.23 ).

As indicated earlier, and in Table 0.22 , the growth in average commercial aircraft fuel efficiency accelerated from an annual rate of 1.9 percent in the 1967-1972 period to 4.6 percent in the ensuing 10 years. These incremental improvements in efficiency relative to historical rates have given $r i s e$ to a steadily increasing level of fuel savings in commercial aircraft. By 1982 , 
fuel savings amounted to 0.186 MMB/D (Line $B$ minus Line $A$ in Figure $D .7$ and Table D.23). Measured relative to the 1972 level of fuel efficiency, the 57.6 percent improvement in average RPM/G over the following 10 years reduced 1982 fuel consumption by 36.5 percent for a total net fuel savings of $0.356 \mathrm{MMB} / \mathrm{D}$ in that year (Line $C$ minus Line $A$ in Figure $D .7$ and Table 0.23 ).

There are several factors that have contributed to the overall improvement in average fuel efficiency and the reduction of fuel use in the commercial aircraft fleet. The foremost among these factors include: 1) changes in aircraft load factors, 2) improved seating densities, 3) shifts in the mix of aircraft in use, and 4) improvements in the technical and operating efficiencies of aircraft. In the following discussion, the fuel savings attributable to changes in each of these components are quantified and are used to disaggregate the total net fuel savings observed over the 1972-1982 time period.

\section{D.3.3 Components of Fuel Efficiency Improvement in Commercial Airlines}

As discussed above, the difference between Line $C$ and Line $A$ in Figure $D .7$ is directly attributable to the overall improvement in the average revenuepassenger miles per gallon of the commercial aircraft fleet. Four factors influence this overall trend in efficiency. These are: load factor (the percentage of available seats filled), seating capacity (the average number of seats per aircraft by model type), mix of aircraft in-use by model type and service category (i.e., domestic trunk vs. international), and technical and operating efficiency (fuel consumed per aircraft mile flown). The annual amount of fuel saved by improvements in each of these factors is estimated by calculating how much fuel would have been required to deliver the actual level of service reported in a given year had the variable under study remained at its 1972 level. The savings attributable to the change in the individual factor is then computed as the difference between the derived value and actual fuel use. 5

5 The methodology used herein attempts to identify and isolate the fuel

(CONT INUED) 
Table D.24 summarizes the annual fuel savings attributed to changes in each of the components of efficiency. Trends in the individual components and their relative fuel savings are discussed below.

\section{D.3.3.1 Load Factor}

Load factor is defined as the percentage of aircraft seats occupied by ticketed passengers. It is therefore a function of both seating capacity and passenger volume. Table 0.25 shows that the average load factor fluctuated around 53 percent between 1972 and 1975. Following the 1975 economic recession, load factor rose steadily to a peak of 62.8 percent in 1979 and then plummetted to 57.4 percent by 1981 before recovering slightly to 58.9 percent in 1982. Both deregulation and the economy have had major impacts. For example, the recession in 1975 reduced the demand for air travel and depressed the growth in revenue-passenger traffic, which caused average load factor to drop. Subsequent improvement in the economy coupled with airline deregulation in 1978 both increased the demand for air travel and enabled the airlines to shed many inefficient routes with low traffic levels--thereby improving overall load factor through 1979. However, deregulation also stimulated the entry of new airlines and added capacity to the commercial air system. As a result, the sudden turnaround in the economy in 1980 and 1981 produced a sharp drop in revenue passenger miles--causing load factor to dip by more than 5 percent.

\section{5 (FOOTNOTE CONTINUED)}

savings caused by changes in an individual component of efficiency under the assumption that there are no interactions between the variables influencing efficiency. In reality, this assumption is not valid. For example, changes in seating capacity and load factor are inextricably intertwined. On routes with a decreasing volume of revenue passenger traffic, air carriers can cut back the frequency of scheduled flights or (depending on stage length and other technical as well as market conditions) use planes with fewer seats per aircraft. Each of these actions influences both the average number of seats per aircraft and the average load factor (the percentage of available seats filled). Thus, the reader should exercise caution in interpreting the absolute levels of fuel savings for each component. Rather, attention should be focused on the relative amount of fuel saved by each component, because the methodology does provide a consistent basis for comparison. (See Smith 1981 for a detailed discussion of methodology.) 
TABLE 0.24. Components of Fuel Efficiency Improvement in the U.S. Commercial Airline Industry

$(M B / D)$

\begin{tabular}{|c|c|c|c|c|c|c|c|}
\hline Year & A & $C$ & LFSAV & STSAV & MXSAV & TOSAV & TOTSAV \\
\hline 1972 & 622 & 622 & 0 & 0 & 0 & 0.0 & 0 \\
\hline 1973 & 623 & 636 & -24 & 33 & 22 & -18.0 & 13 \\
\hline 1974 & 567 & 642 & 17 & 39 & 19 & 0.2 & 75 \\
\hline 1975 & 565 & 641 & 4 & 51 & 20 & 0.8 & 76 \\
\hline 1976 & 590 & 712 & 24 & 67 & 22 & 9.0 & 122 \\
\hline 1977 & 620 & 766 & 31 & 86 & 26 & 3.0 & 146 \\
\hline 1978 & 637 & 889 & 101 & 110 & 34 & 7.0 & 252 \\
\hline 1979 & 674 & 993 & 123 & 153 & 30 & 13.0 & 319 \\
\hline 1980 & 647 & 944 & 72 & 164 & 31 & 30.0 & 297 \\
\hline 1981 & 616 & 912 & 50 & 183 & 28 & 35.0 & 296 \\
\hline 1982 & 611 & 963 & 66 & 218 & 28 & 40.0 & 352 \\
\hline
\end{tabular}

\footnotetext{
$A=$ Actual fuel consumption

$C=$ Constant 1972 fuel efficiency with actual activity growth LFSAV = Fuel savings due to improvements in load factor

STSAV = Fuel savings due to changes in seating capacity

MXSAV = Fuel savings from changes in the mix of aircraft in use

TOSAV = Fuel savings from improvements in aircraft technical and operating efficiency

TOTSAV = Total net fuel savings $(C-A)$
} 
TABLE 0.25 . Summary Statistics for Commercial Aircraft

\begin{tabular}{|c|c|c|c|c|}
\hline Year & $\begin{array}{c}\text { Average } \\
\text { Load-Factor }\end{array}$ & $\begin{array}{l}\text { Average Seats } \\
\text { Per Aircraft } \\
\end{array}$ & $\begin{array}{l}\text { Average Seats } \\
\text { Miles/Gallon } \\
\end{array}$ & $\begin{array}{l}\text { Average Gallons/ } \\
1000 \text { Aircraft Miles }\end{array}$ \\
\hline 1972 & 53.2 & 127 & 31.8 & 4005 \\
\hline 197 & 52.1 & 135 & 33.1 & 4072 \\
\hline 197 & 54.6 & 140 & 35.0 & 4003 \\
\hline 1975 & 53.5 & 143 & 35.9 & 4000 \\
\hline 1976 & 55.5 & 147 & 37.0 & 3979 \\
\hline 1977 & 55.7 & 150 & 37.6 & 3985 \\
\hline 1978 & 61.3 & 153 & 38.5 & 3969 \\
\hline 1979 & 62.8 & 156 & 39.7 & 3931 \\
\hline 198 & 59.0 & 160 & 41.8 & 3839 \\
\hline 198 & 57.4 & 165 & 43.6 & 3788 \\
\hline 198 & 58.9 & 170 & 45.3 & 3757 \\
\hline
\end{tabular}

Source: Civil Aeronautics Board

Measured from a 1972 baseline, the effect of the growth in load factor on fuel efficiency increases rapidly through 1979. If load factor had remained at its 1972 level in 1979, an additional 0.123 MMB/D of jet fuel would have been required to deliver the actual passenger miles. After 1979, the savings attributable to load factor drop as the average percentage of seats filled also declines. In 1982, load factor fuel savings amount to about $0.066 \mathrm{MMB} / \mathrm{D}$.

\section{D.3.3.2 Seating Capacity}

Adding more seats per aircraft allows the airlines to reduce operating costs and fuel costs in that fewer planes and/or fewer flights need to be scheduled to service the passenger traffic volume on a particular route. Although more seats can add weight to aircraft, which increases gallons consumed per vehicle mile, the additional capacity allows more revenue passengers per aircraft and thereby has a positive effect on revenue passenger miles per gallon. For example, the average number of seats on a Boeing 727-200 increased from 123 in 1972 to 137 by 1981. As a result, the gallons consumed per seat-mile dropped by 21.5 percent over the same time period. Seating capacity also has increased on the wide-bodied jets. The number of seats on a 
Boeing 747 rose from 328 in 1972 to 387 in 1981 and contributed to a 20.6 percent fall in gallons per seat mile over the same time period.

Table 0.25 shows the trend in the average number of seats per aircraft. The average seating capacity rose 33.8 percent from 127 seats in 1972 to 170 seats in 1982. These figures include the effect of the shift in mix to the wide-bodied aircraft. However, even if the effect of mix shift is removed, the contribution of seating capacity to fuel efficiency is substantial. By 1982 , the increase in seating density accounted for fuel savings of about 0.218 $M M B / D$.

\section{D.3.3.3 Mix Shift}

One of the key elements influencing improvements in the efficiency of air travel service is the mix of aircraft in use. During the 1970s, the mix of aircraft in the fleet changed significantly. In 1972, for example, the Boeing 707 series accounted for almost 19 percent of the total seat-miles flown by the fleet. By 1982 , the Boeing 707 contributed only 1 percent of the total seatmiles. The share of the wide-bodied jets (Boeing 747, McDonnell Douglas DC-10 and Lockheed L-1011), on the other hand, rose from 18 percent of the total seatmiles in 1972 to 43 percent by 1982. Although wide-bodied jets are less efficient than regular-bodied jets on a gallons per aircraft mile measure, they are more productive in that they can seat more passengers per gallon. In 1982, for example, the wide-bodied jets averaged about 52.4 seat-miles per gallon in comparison with $37.2 \mathrm{SM} / \mathrm{G}$ for the Boeing 707 series and $42.1 \mathrm{SM} / \mathrm{G}$ for the average Boeing 727-200 (which contributed 30.6 percent of the total seat-miles in that year).

As shown in Table 0.24 , fuel savings from shifts in the mix of aircraft in use rose to a peak of $0.034 \mathrm{MMB} / \mathrm{D}$ in 1978 and then declined to about 0.028 $M M B / D$ by 1982 , largely as a result of a slight shift away from the predominance of wide-bodied jets caused by the entrance and growth of smaller regional carriers following deregulation and the over-capacity problems confronted by the major trunk carriers during the economic recession of 1980-1981.

\section{D.3.3.4 Technical and Operating Efficiency}

Improvements in this component are influenced by a multitude of factors. These include: 1) improvements in jet engine efficiency; 2) reduced cruise 
speeds; 3) more efficient takeoff, landing and taxiing procedures (i.e., landing with steeper angles of descent and/or taxiing with one or more engines shut off); 4) reduced aircraft weight; and 5) revised maintenance procedures. With respect to improved jet engines, the new families of power plants such as the Pratt and Whitney JT9D, the General Electric CF6 and the Rolls Royce RB211 have been shown to offer substantial reductions in fuel consumption compared to older engines such as the JT3D (used widely on B-707s). Gallons consumed per aircraft mile for most aircraft has decreased between 1972 and 1982. For example, the technical and operating efficiency of the Boeing 747 improved 6.9 percent between 1972 and 1982. The fuel consumed by the Boeing 727-200 also dropped by 12.1 percent (in terms of gallons/aircraft mile) between 1972 and 1982.

Technical and operating efficiency improvements declined sharply in 1973 and then increased gradually through 1978. After 1978, fuel savings attributable to technical and operating efficiency accelerated due probably largely to the effect of deregulation on route restructuring to optimize efficiency and the influence of the 1979 oil price hike on airline fuel costs. (Between 1973 and 1980, air carrier fuel expenses rose from 12 percent to 31 percent of total operating costs.) In 1982, technical and operating efficiency improvements accounted for about $0.04 \mathrm{MMB} / 0$ in fuel savings relative to 1972 levels.

\section{D.3.3.5 Surmary of Components}

Table 0.24 and Figure 0.8 summarize the savings attributable to the four components of improved aircraft efficiency. The growth in seating capacity is the component with the largest impact on improved fuel efficiency in the 19721982 time period. In 1982, increased seating density accounted for 61.9 percent $(0.218 \mathrm{MMB} / D)$ of the total savings. Improvements in load factor ranked second in $1982--$ contributing 18.8 percent $(0.66 \mathrm{MMB} / D)$ of the total fuel savings. Changes in technical and operating efficiency and shifts in the mix of aircraft in use ranked third and fourth, respectively, in 1982. Technical and operating efficiency improvements reduced 1982 fuel consumption by about 
FIGURE D.8. COMPONENTS OF FUEL EFFICIENCY IMPROVEMENTS

IN THE U.S. COMMERCIAL AIRLINE INDUSIRY

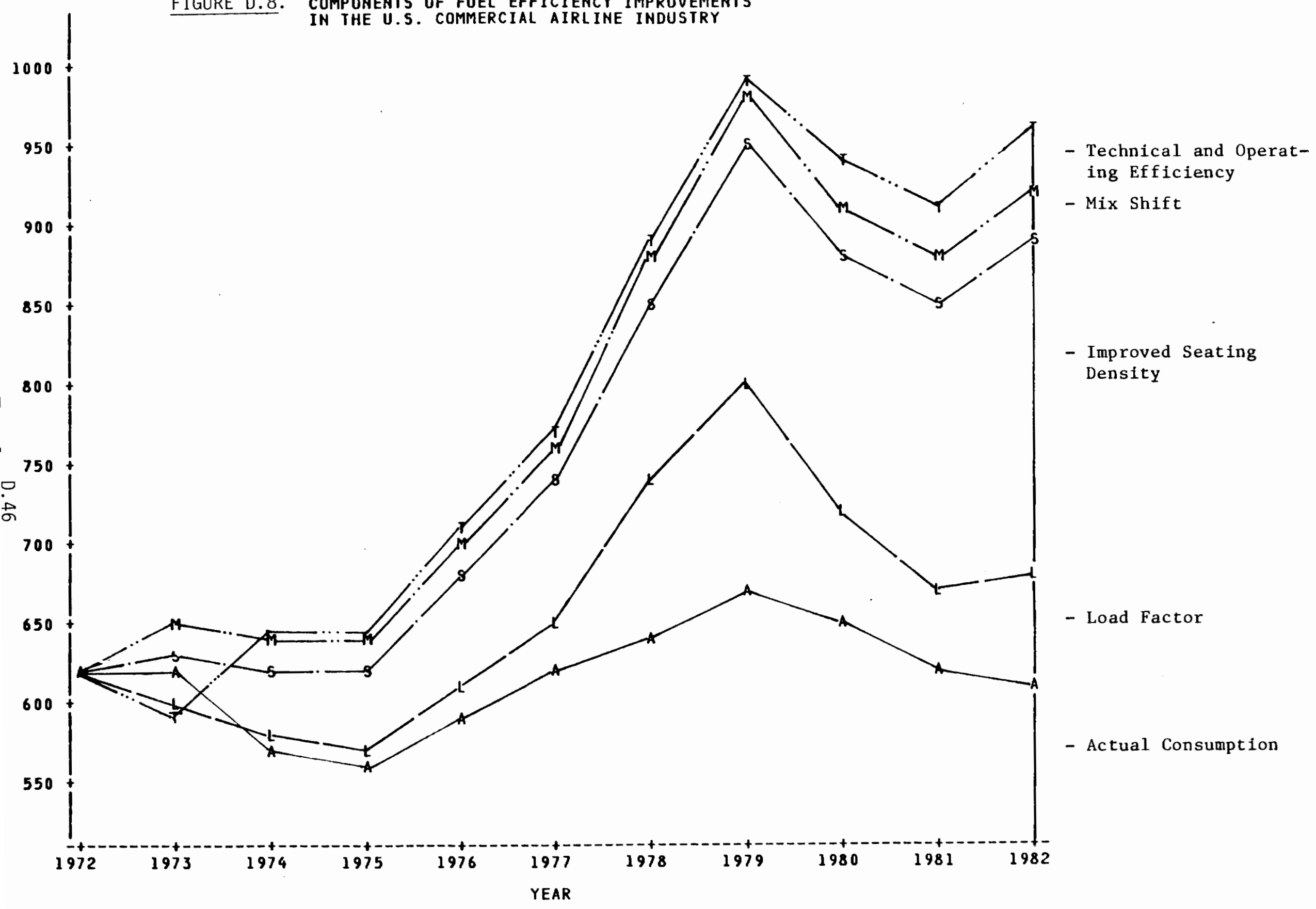


11.4 percent $(0.040 \mathrm{MMB} / \mathrm{D})$, and shifts in mix reduced fuel demand by 8 percent $(0.028 \mathrm{MMB} / \mathrm{D})$ in 1982 .

\section{D.4 RAIL/WATER}

The rail and water modes accounted for 3.3 percent and 8.6 percent, respectively, of the total energy consumed in transportation in 1980 . Between 1970 and 1980, energy consumed by railroads increased a total of 8.7 percent while the level of rail activity (measured in revenue ton-miles) increased by over 20 percent. Similarly, energy used in domestic waterborne commerce grew by over 11 percent between 1970 and 1979, while the level of shipping activity rose 39 percent over the same time period. Thus, substantial improvements have been made in the technological and operating efficiency of the rail and water modes. Unfortunately, however, the available data are insufficient to perform a detailed disaggregation and quantification of the components influencing trends in the fuel use and efficiency of the rail and water modes. Therefore, the following discussion will focus primarily on the overall trends in conservation in each of the two sectors.

\section{D.4.1 Rail}

Due to problems of data availability and data consistency, the analysis of railroad fuel consumption and activity levels focused on Class 1 railroads (as defined by the U.S. Interstate Commerce Commission). In 1981, there were 38 reporting Class 1 railroad companies. These 38 companies accounted for about 98 percent of the total railroad traffic and operated approximately 94 percent of the total rail mileage. The Class 1 railroads also were predominately in the freight hauling business. In 1981, 94 percent of total operating revenues of Class 1 railroads came from freight traffic (2\% was from passenger traffic and $4 \%$ from other revenue sources).

In evaluating fuel consumption in the rail sector, the methodology developed by PNL for quantifying trends in fuel conservation due to changes in efficiency (ton-miles per gallon) and changes in activity (revenue ton-miles) was employed (Fang and Adams 1983). The five estimates of actual fuel consumption (A) and of what fuel consumption would have been under alternative assumptions regarding trends in efficiency and activity ( $B, C, D$, and $E$ ) are presented in Figure 0.9 and Table 0.26 . 
FIGURE D.9. FUEL CONSUMPTION IN THE RAILROAD SECTOR

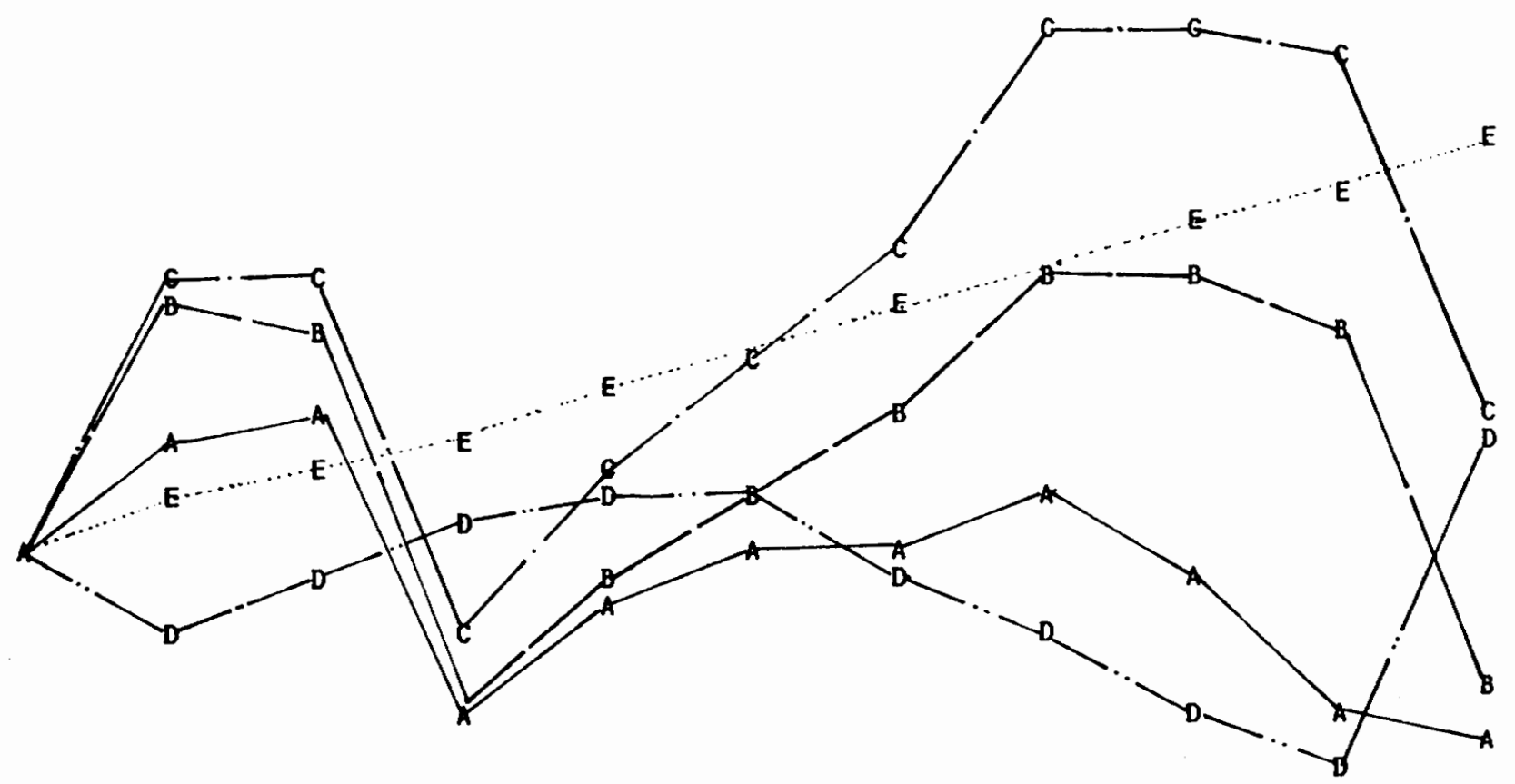

0.240

0.235

0.230

0.225

0.220

0.215

0.210

0.205

0.200

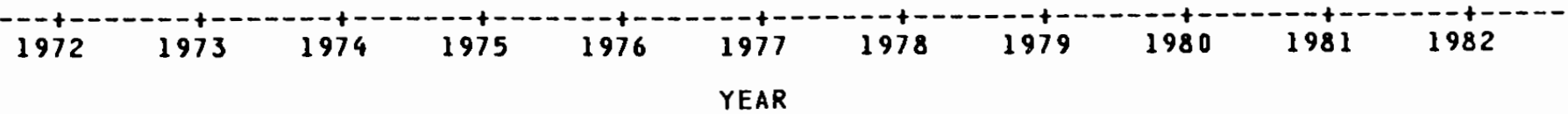

EAR 
TABLE D.26. Actual Railroad Fuel Use and Alternative Base Cases $(M M B / D)$

\begin{tabular}{lllllll} 
Year & $-\mathrm{A}$ & $\mathrm{B}$ & $\mathrm{C}$ & $\mathrm{D}$ & $-\mathrm{E}$ \\
\cline { 2 - 2 } 1972 & 0.261 & 0.261 & 0.261 & 0.261 & 0.261 \\
1973 & 0.271 & 0.283 & 0.286 & 0.251 & 0.264 \\
1974 & 0.272 & 0.280 & 0.286 & 0.256 & 0.268 \\
1975 & 0.244 & 0.246 & 0.253 & 0.263 & 0.271 \\
1976 & 0.254 & 0.257 & 0.267 & 0.264 & 0.275 \\
1977 & 0.260 & 0.264 & 0.277 & 0.264 & 0.278 \\
1978 & 0.259 & 0.272 & 0.288 & 0.257 & 0.282 \\
1979 & 0.266 & 0.285 & 0.307 & 0.251 & 0.285 \\
1980 & 0.257 & 0.285 & 0.308 & 0.246 & 0.289 \\
1981 & 0.245 & 0.280 & 0.306 & 0.240 & 0.293 \\
1982 & 0.243 & 0.247 & 0.273 & 0.269 & 0.297
\end{tabular}

\footnotetext{
$A=$ Actual fuel use

$B=$ Trended fuel efficiency with actual activity growth

$C=$ Constant 1972 fuel efficiency with actual activity growth

$D=$ Actual fuel efficiency with trended activity growth

$E=$ Trended fuel efficiency with trended activity growth
}

As shown in Figure 0.9 , total railroad fuel consumption is highly sensitive to trends in the level of rail freight activity. Railroad fuel use rose from $0.261 \mathrm{MMB} / \mathrm{D}$ in 1972 to $0.272 \mathrm{MMB} / \mathrm{D}$ in 1974 and then dropped to 0.244 MMB/D by 1975--largely reflecting the 11.4 percent decline in revenue ton-miles induced by the recession of that year (1975). (See Table D.27.) Railraod fuel demand subsequently rose to a peak of $0.266 \mathrm{MMB} / \mathrm{D}$ in 1979 and then fell to $0.243 \mathrm{MMB} / \mathrm{D}$ by 1982, again primarily as a result of the depressing effects of economic recession on rail freight activity.

If, during the past decade, railraods had continued to consume fuel at the same rate of growth experienced in the 1960s and early 1970 s (a 1.3 percent annual rate), fuel usage in 1982 would have been almost 22 percent $(0.54 \mathrm{MMB} / 0$ ) higher than what actually occurred (Line $E$ minus Line $A$ in Figure $D .9$ and Table $0.28)$. Much of the "reduction" in fuel demand that has occurred in the rail sector in the post-1978 time period has been the result of improvements in technological and operating efficiency. As shown in Table 0.27 , the growth in 
TABLE D.27. Railroad Fuel Efficiency and Activity Levels

\begin{tabular}{lrrrrr} 
& \multicolumn{2}{c}{ Actual } & \multicolumn{2}{c}{ Trended } \\
\cline { 2 - 3 } \cline { 5 - 6 } Year & TMGA & TMTACT & & TMGT & TMTREND \\
1972 & 194 & 776.7 & & 194 & 776.7 \\
1973 & 205 & 85.8 & & 196 & 788.7 \\
1974 & 204 & 85.8 & & 198 & 800.8 \\
1975 & 202 & 754.3 & & 200 & 813.1 \\
1976 & 204 & 794.1 & & 202 & 825.7 \\
1977 & 207 & 826.3 & & 204 & 838.4 \\
1978 & 216 & 858.1 & 206 & 851.3 \\
1979 & 224 & 913.7 & 209 & 864.4 \\
1980 & 233 & 918.6 & 210 & 877.7 \\
1981 & 242 & 911.7 & 212 & 891.2 \\
1982 & 220 & 812.0 & 214 & 905.0
\end{tabular}

TMGA = Actual ton-miles per gallon

TMTACT = Actual total revenue ton-miles

TMGT = Trended ton-miles per gallon (based on 1967-1972 growth rates)

TMTREND = Trended total revenue ton-miles (based on 1967-1972 growth rates)

Source: Association of American Railroads

Note: Figures refer to Class 1 railroads 
TABLE D.28. Alternative Estimates of Railraod Fuel Savings $(M M B / D)$

\begin{tabular}{|c|c|c|c|c|c|}
\hline Year & TGESE & ACSEB & ACSDA & MEUICS & TOTNES \\
\hline 1972 & 0.000 & 0.000 & 0.000 & 0.000 & 0.000 \\
\hline 1973 & -0.007 & -0.019 & -0.020 & 0.012 & 0.015 \\
\hline 1974 & -0.004 & -0.012 & -0.016 & 0.008 & 0.014 \\
\hline 1975 & 0.027 & 0.025 & 0.019 & 0.002 & 0.009 \\
\hline 1976 & 0.021 & 0.018 & 0.010 & 0.003 & 0.013 \\
\hline 1977 & 0.018 & 0.014 & 0.004 & 0.004 & 0.017 \\
\hline 1978 & 0.023 & 0.010 & -0.002 & 0.013 & 0.029 \\
\hline 1979 & 0.019 & 0.000 & -0.015 & 0.019 & 0.041 \\
\hline 1980 & 0.032 & 0.004 & -0.011 & 0.028 & 0.051 \\
\hline 1981 & 0.048 & 0.013 & -0.005 & 0.035 & 0.061 \\
\hline & 0.054 & 0.050 & 0.026 & 0.004 & 0.030 \\
\hline
\end{tabular}

TGESE = Total gross fuel savings according to Line $E(E-A)$ $A C S D A=$ Activity change savings according to Lines $D$ and $A(D-A)$ $A C S E B=$ Activity change savings according to Lines $E$ and $B(E-B)$ MEUICS = Marginal fuel efficiency change savings $(B-A)$

TOTNES = Total net fuel savings $(C-A)$ 
average ton-miles per gallon in the rail sector actually accelerated in the 1972-1981 time period (at 2.5 percent per year) compared to just under 1 percent per year in the 1967-1972 time period. The fuel savings attributable to this marginal improvement in fuel efficiency relative to historical trends amounted to about 0.035 MMB/D by 1981. (See Line B minus Line A in Figure D.9 and Table 0.28.) Due to the 9 percent drop in average ton-miles per gallon which occurred between 1981 and 1982, the savings from marginal efficiency improvements declined to $0.004 \mathrm{MMB} / \mathrm{D}$ in 1982. A similar pattern is evident in observing the total net fuel savings attributable to improvements in the average fuel efficiency relative to 1972 levels. The 24.7 percent growth in average ton-miles per gallon between 1972 and 1981 yielded 1981 total net fuel savings of $0.061 \mathrm{MMB} / \mathrm{D}$. (See Line $C$ minus Line $A$ in Figure 0.9 and Table D.28.) Again, the subsequent 9 percent drop in fuel efficiency between 1981 and 1982 reduced these savings to about $0.030 \mathrm{MMB} / 0$. Nevertheless, savings due to these changes in efficiency have been significantly greater than the savings attributable to reductions in activity. In fact, between 1978 and 1981, the growth in activity actually increased (at 2.5 percent per year) relative to historical (1967 to 1972) trends (of 1.5 percent/year) and produced negative fuel savings of up to $-0.015 \mathrm{MMB} / D$ in that period. (See Line $D$ minus Line $A$ in Figure 0.9 and Table D.28.) Even though the subsequent 10 percent drop in revenue ton-miles between 1981 and 1982 yielded positive savings of $0.026 \mathrm{MMB} / \mathrm{D}$ (in 1982), these are still somewhat less than the total net fuel savings attributable to the gains in efficiency achieved since 1972 .

\section{D.4.2 Water Mode}

Vessels used in water transportation are typically classified in one of three categories: domestic freight trade, international freight trade, and recreational boating. The most complete time series of available data on energy use and activity cover only those vessels engaged in domestic waterborne freight commerce. Therefore, this analysis will focus specifically on that component. The reader should recognize, however, that domestic waterborne commerce accounts for only 22 percent of the total energy consumed by the water mode (based on 1979 data; ORNL). 
Table 0.29 presents summary statistics for vessels engaged in domestic waterborne commerce. Between 1972 and 1977, the growth in ton-miles was essentially stagnant or negative--well below the three percent annual average increases experienced in the late 1960s. Beginning in 1978, however, ton-miles grew sharply due primarily to an increase in crude petroleum shipments from Alaska--a consequence of the completion of the Alaskan pipeline. Over the entire 1972-1981 time period, total ton-miles increased by 54 percent, but the total volume of fuel consumed by domestic waterborne commerce grew by only 13 percent. This was primarily a reflection of the substantial increase in the technological and operating efficiency of the fleet. The average energy use intensity of domestic waterborne commerce fell 26 percent from 522 Btu/ton-mile in 1972 to $385 \mathrm{Btu} /$ ton-mile in 1981 .

TABLE 0.29 . Summary Statistics for Domestic Waterborne Commerce

\begin{tabular}{lccc} 
Year & $\begin{array}{c}\text { Energy Use } \\
(\text { MMB/D })\end{array}$ & $\begin{array}{c}\text { Ton-Miles } \\
\left(\times 10^{9}\right)\end{array}$ & $\begin{array}{c}\text { Energy Intensity } \\
\text { Btu/Ton-Mile }\end{array}$ \\
\cline { 2 - 3 } 1972 & 0.160 & 603.5 & 522 \\
1973 & 0.171 & 584.7 & 576 \\
1974 & 0.144 & 586.3 & 483 \\
1975 & 0.158 & 566.0 & 549 \\
1976 & 0.141 & 591.9 & 468 \\
1977 & 0.139 & 599.0 & 458 \\
1978 & 0.161 & 827.3 & 383 \\
1979 & 0.184 & 828.8 & 437 \\
1980 & 0.172 & 921.6 & 368 \\
1981 & 0.181 & 929.4 & 385 \\
1982 & 0.146 & 850.0 & 338
\end{tabular}

\footnotetext{
Source: Oak Ridge National Laboratory, Transportation Energy

Conservation Data Book, 6th ed., and personal communication with officials in the U.S. Army Corps of Engineers and U.S. Energy Information Administration.
}

Figure D.10 and Table D.30 show the 1972 to 1982 trends in actual fuel consumption (A) and what might have occurred under alternative assumptions regarding fuel efficiency and activity in the water mode. If the historical (1967 to 1972) growth (1.3 percent/year) of fuel use had continued throughout 
1

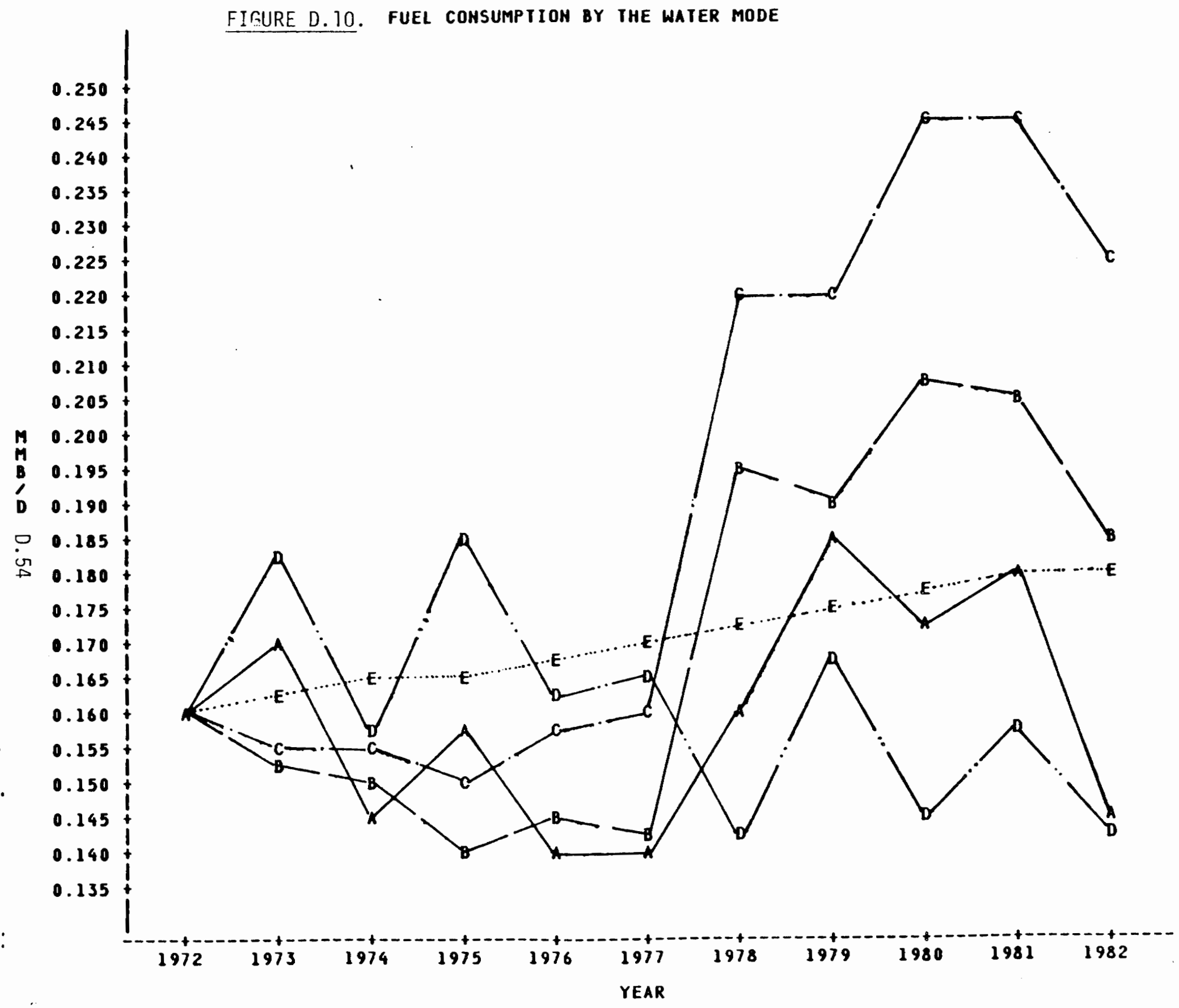


the 1972-1982 time period, fuel consumption in 1982 would have been almost 24 percent $(0.035 \mathrm{MMB} / D$ ) higher than what actually occurred (Line $E$ minus Line $A$ in Figure 0.10 and Table D.31). The bulk of these savings (particularly since 1978) represent improvements in the technological and operating efficiency of the fleet. Measured with respect to the 1967-1972 annual drop in energy use intensity (of about 2 percent per year), the increased rate of decline (of about 4 percent per year) experienced in the subsequent decade yielded fuel savings of $0.038 \mathrm{MMB} / D$ by 1982 (Line $B$ minus Line $A$ in Figure $D .10$ and Table D.31). Relative to the 1972 level of efficiency, the average energy use intensity of the water mode dropped by about 35 percent over the next ten years. In 1982, this improvement in efficiency produced total net fuel savings of about $0.079 \mathrm{MMB} / \mathrm{D}$. (See Line $C$ minus Line $A$ in Figure $D .10$ and Table D.31.)

TABLE D.30. Actual Fuel Use and Alternative Base Cases for the Water Mode (MMB/D)

\begin{tabular}{lccccc} 
Year & $\mathrm{A}$ & $\mathrm{B}$ & $\mathrm{C}$ & $\mathrm{D}$ & $-\mathrm{E}$ \\
\cline { 2 - 2 } 1972 & 0.160 & 0.160 & 0.160 & 0.160 & 0.160 \\
1973 & 0.171 & 0.152 & 0.155 & 0.182 & 0.162 \\
1974 & 0.144 & 0.149 & 0.155 & 0.158 & 0.164 \\
1975 & 0.158 & 0.141 & 0.150 & 0.185 & 0.166 \\
1976 & 0.141 & 0.145 & 0.157 & 0.163 & 0.168 \\
1977 & 0.139 & 0.143 & 0.159 & 0.164 & 0.170 \\
1978 & 0.161 & 0.194 & 0.219 & 0.142 & 0.172 \\
1979 & 0.184 & 0.190 & 0.220 & 0.167 & 0.175 \\
1980 & 0.172 & 0.208 & 0.244 & 0.145 & 0.177 \\
1981 & 0.181 & 0.205 & 0.246 & 0.157 & 0.179 \\
1982 & 0.146 & 0.184 & 0.225 & 0.142 & 0.181
\end{tabular}

\footnotetext{
$A=$ Actual fuel use

$B=$ Trended fuel efficiency with actual activity growth

$C=$ Constant 1972 fuel efficiency with actual activity growth

$D=$ Actual fuel efficiency with trended activity growth

$E=$ Trended fuel efficiency with trended activity growth
} 
TABLE D.31. Alternative Estimates of Fuel Savings for the Water Mode

(MMB/D)

$\begin{array}{lrrrrr}\text { Year } & \text { TGESE } & \text { ACSEB } & \text { ACSDA } & \text { MEUICS } & \text { TOTNES } \\ & & & & & \\ 1972 & 0.000 & 0.000 & 0.000 & 0.000 & 0.000 \\ 1973 & -0.009 & 0.010 & 0.011 & -0.019 & -0.016 \\ 1974 & 0.020 & 0.015 & 0.014 & 0.005 & 0.011 \\ 1975 & 0.008 & 0.025 & 0.027 & -0.017 & -0.008 \\ 1976 & 0.027 & 0.023 & 0.022 & 0.004 & 0.016 \\ 1977 & 0.031 & 0.027 & 0.025 & 0.004 & 0.020 \\ 1978 & 0.011 & -0.022 & -0.019 & 0.033 & 0.058 \\ 1979 & -0.009 & -0.015 & -0.017 & 0.006 & 0.036 \\ 1980 & 0.005 & -0.031 & -0.027 & 0.036 & 0.072 \\ 1981 & -0.002 & -0.026 & -0.024 & 0.024 & 0.065 \\ 1982 & 0.035 & -0.003 & -0.004 & 0.038 & 0.079\end{array}$

\footnotetext{
TGESE = Total gross fuel savings according to Line $E(E-A)$

$A C S D A=$ Activity change savings according to Lines $D$ and $A(D-A)$

ACSEB = Activity change savings according to Lines $E$ and $B(E-B)$

MEUICS = Marginal fuel efficiency change savings ( $B-A)$

TOTNES = Total net fuel savings $(C-A)$
}

In contrast, changes in activity have actually resulted in increases in fuel consumption. In 1978, the opening of the Alaskan pipeline produced a 38 percent jump in domestic waterborne freight movements relative to 1977 . This increase in activity contributed negative fuel savings which grew from -0.019 $M M B / D$ in 1978 to $-0.027 \mathrm{MMB} / D$ in 1980. However, these negative fuel savings have since declined sharply as the growth in activity slowed and then reversed in the 1980-1982 time period. In 1982, changes in the growth of activity accounted for fuel savings of $-0.004 \mathrm{MMB} / D$. (See Line $D$ minus Line $A$ in Figure 0.10 and Table 0.31.)

\subsection{REFERENCES}

DiFiglio, Carmen, and Barry McNutt. 1982. "Passenger Car Fuel Demand Reduction - An Analys is of the Causes and Implications." Analysis Memorandum. Division of Conservation and Renewable Energy, OPPA, U.S. Department of Energy. 
Energy and Environmental Analysis, Inc. (EEA) 1982a. Fuel Demand and Fuel Efficiency in the U.S. Commercial Airline Industry and Trucking Industry: An Analysis of Trends and Implications. Prepared for the U.S. Department of Energy by EEA.

Energy and Environmental Analysis, Inc. (EEA) 1982b. "Recent Trends in LightDuty Truck Performance." Analys is Memorandum for Division of Conservation and Renewable Energy, OPPA, U.S. Department of Energy.

Energy and Environmental Analysis, Inc. (EEA) 1983. "The Highway Fuel Consumption Model: Tenth Quarterly Report." Prepared for the U.S. Department of Energy by EEA.

Fang, J.M., and R.C. Adams. 1983. A Consistent Approach for Analyzing Energy Consumption Trends by End-Use Sector. Prepared for the U.S. Department of Energy by Pacific Northwest Laboratory.

Marino, Annunciata E. 1982. Trends in Energy Use and Fuel Efficiency of Light Trucks: 1973-1980. Division of Conservation and Renewable Energy, OPPA, U.S. Department of Energy.

Mason, R.L., and R.W. Zubb. 1981. Highway Fuel Economy Study. Prepared for U.S. Department of Transportation/NHTSA, Office of Research and Development.

Oak Ridge National Laboratory (ORNL). Transportation Energy Conservation Data Book. 6th ed.

Smith, Joel B. 1981. Trends in Energy Use and Fuel Efficiency in the U.S. Commercial Airline Industry. Division of Conservation and Renewable Energy, OPPA, U.S. Department of Energy. 


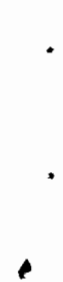

$$
\bullet
$$

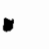

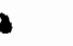




\section{APPENDIX E}

\section{GENERAL METHODOLOGY FOR MEASURING ENERGY SAVINGS}


- 


\section{APPENDIX E}

\section{GENERAL METHODOLOGY FOR MEASURING ENERGY SAVINGS}

In this appendix, we first demonstrate the energy savings categories explained in Chapter 1.0 by algebraic expressions, and then describe the procedures for deriving historical growth rates, trended values of economic activity, energy use intensity, and economy-wide aggregation.

\section{E.1 ALGEBRAIC DEFINITIONS OF ENERGY SAVINGS}

In mathematical terms, the values for energy savings can be represented algebraically by five expressions:

$$
\begin{aligned}
& \text { Line A: } \operatorname{EUA}(J)_{t}=\operatorname{EUI}(J)_{t} \cdot x(J)_{t} \\
& \text { Line B: } \operatorname{EUB}(J)_{t}=\operatorname{EUI}(J)_{t} \cdot x(J)_{t} \\
& \text { Line C: } \operatorname{EUC}(J)_{t}=\operatorname{EUI}(J)_{72} \cdot x(J)_{t} \\
& \text { Line D: } \operatorname{EUD}(J)_{t}=\operatorname{EUI}(J) \cdot \hat{x}(J)_{t} \\
& \text { Line E: } \operatorname{EUE}(J)_{t}=\operatorname{EUI}(J)_{t} \cdot x(J)_{t}
\end{aligned}
$$

where

$$
\begin{aligned}
& \operatorname{EUA}(J)_{t}, \operatorname{EUB}(J)_{t}, \operatorname{EUC}(J)_{t}, \operatorname{EUD}(J)_{t} \text {, and } \operatorname{EUE}(J)_{t} \text { are total } \\
& \text { energy use for sector } J \text { in year } t \text { for Lines } A, B, C, D \text {, and } E \text {, } \\
& \text { respectively; } \\
& E U I(J)_{t} \text { is the actual energy use intensity for sector } J \text { in year } t \text {; } \\
& \hat{E U I}(J)_{t} \text { is the trended energy use intensity for sector } J \text { in year } t \text {; } \\
& \operatorname{EUI}(J)_{72} \text { is the energy use intensity for sector } J \text { in 1972; } \\
& X(J)_{t} \text { is the actual economic activity for sector } J \text { in year } t \text {; } \\
& \hat{x}(J)_{t} \text { is the trended economic activity for sector } J \text { in year } t \text {; } \\
& J \text { is the sector index, equal to RS (residential), CM (commercial), IN } \\
& \text { (industrial), and TR (transportation); } \\
& t \text { is the year index, represented by the last two digits only. }
\end{aligned}
$$


Given the above expressions, we can algebraically represent the various energy concepts described in Table E.1. These various concepts are defined below.

\section{E.1.1 Energy Savings Due to Changes in Economic Activity}

There are two ways to measure these energy savings: Line $D$ minus $L$ ine $A$, or Line $E$ minus Line $B$. In the first case, we can write:

$$
\begin{aligned}
\operatorname{EUD}(J)_{t}-\operatorname{EUA}(J)_{t} & =\operatorname{EUI}(J)_{t} \cdot \hat{x}(J)_{t}-\operatorname{EUI}(J)_{t}-x(J)_{t} \\
& =\operatorname{EUI}(J)_{t} \cdot\left(\hat{x}(J)_{t}-x(J)_{t}\right)
\end{aligned}
$$

In the second case, we have

$$
\begin{aligned}
\operatorname{EUE}(J)_{t}-\operatorname{EUB}(J)_{t} & =\hat{E U I}(J)_{t} \cdot \hat{x}(J)_{t}-\hat{E U I}(J)_{t} \cdot x(J)_{t} \\
& =\operatorname{EUI}(J)_{t} \cdot\left[\hat{x}(J)_{t}-x(J)_{t}\right]
\end{aligned}
$$

Since only the economic activity variables are changed (i.e., $\left.\hat{x}(J)_{t}-x(J)_{t}\right)$, energy savings in these two cases are attributed to changes in economic activity. Although Equations E.6 and E.7 represent the same measure of energy savings attributable to changes in economic activity, it is not clear which of the two is the more appropriate measure. More empirical work would be necessary to determine this. In our analysis, we adopt the measure involving Lines $D$ and $A$, which are explained by actual, rather than trended, energy use intensities.

\section{E.1.2 Energy Savings Due to Energy Efficiency Improvements Since 1972} (Line $C$ - Line $A)$

The difference between Line $C$ and Line $A$ is measured by:

$$
\begin{aligned}
\operatorname{EUC}(\mathrm{J})_{\mathrm{t}}-\operatorname{EUA}(\mathrm{J})_{\mathrm{t}} & =\operatorname{EUI}(\mathrm{J})_{72} \cdot x(\mathrm{~J})_{t} \cdot-\operatorname{EUI}(\mathrm{J})_{t} \cdot x(\mathrm{~J})_{t} \\
& =x(J)_{t} \cdot\left[\operatorname{EUI}(\mathrm{J})_{72}-\operatorname{EUI}(\mathrm{J})_{t}\right]
\end{aligned}
$$

Since the activity levels $X(J)_{t}$ are to be the same for both Lines $C$ and $A$, energy savings are attributed to the change in efficiency levels from 1972 to actually observed levels. 
TABLE E.1. Concepts of "Energy Savings"

\begin{tabular}{|c|c|c|c|c|}
\hline \multirow{2}{*}{ 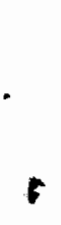 } & \multirow[b]{2}{*}{ Concept } & \multicolumn{2}{|c|}{ Changes In } & \multirow{2}{*}{$\begin{array}{c}\text { Difference } \\
\text { Between } \\
\text { Lines } \\
\text { (See Fig. E.1) }\end{array}$} \\
\hline & & Economic Activity & EUIs & \\
\hline \multirow{5}{*}{ 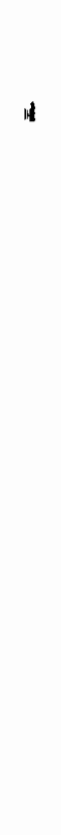 } & $\begin{array}{l}\text { Economic Activity } \\
\text { Change Savings: }\end{array}$ & & & \\
\hline & 1) $D-A$ Alternative & $\begin{array}{l}\text { From trended to } \\
\text { actual activity } \\
\text { level }\end{array}$ & $\begin{array}{l}\text { No change; actual } \\
\text { EUIs }\end{array}$ & $D-A$ \\
\hline & 2) E-B Alternative & $\begin{array}{l}\text { From trended to } \\
\text { actual activity } \\
\text { level }\end{array}$ & $\begin{array}{l}\text { No change; trended } \\
\text { EUIs }\end{array}$ & $E-B$ \\
\hline & $\begin{array}{l}\text { Energy Efficiency } \\
\text { Improvements } \\
\text { Relative to Trends }\end{array}$ & $\begin{array}{l}\text { No change; actual } \\
\text { activity level }\end{array}$ & $\begin{array}{l}\text { From trended EUIs } \\
\text { to actual EUIs }\end{array}$ & $B-A$ \\
\hline & $\begin{array}{l}\text { Energy Efficiency } \\
\text { Improvements } \\
\text { Since } 1972\end{array}$ & $\begin{array}{l}\text { No change; actual } \\
\text { activity level }\end{array}$ & $\begin{array}{l}\text { From } 1972 \text { EUIs } \\
\text { to actual EUIs }\end{array}$ & C-A \\
\hline
\end{tabular}




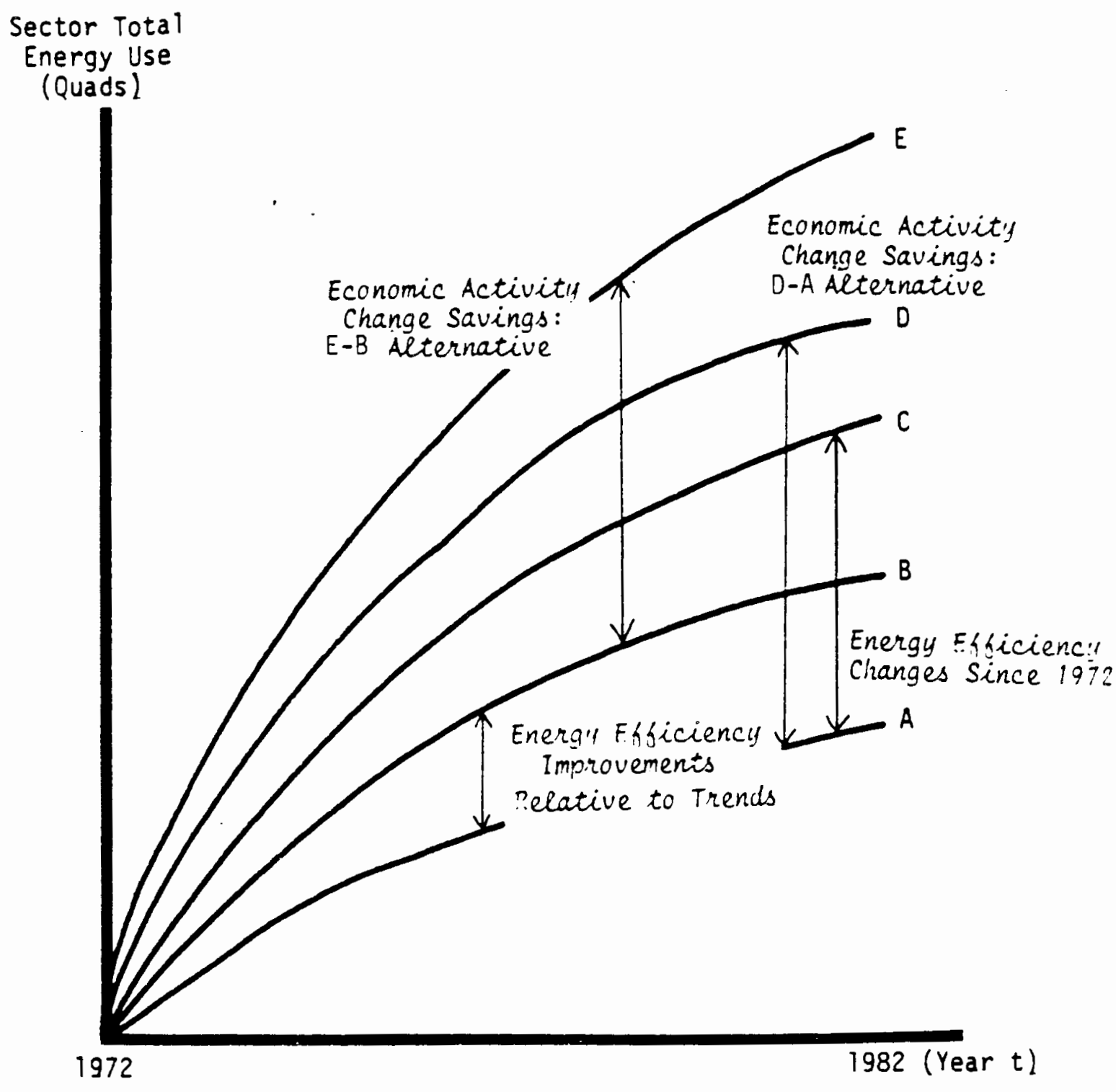

Line A: Actual Energy Use

Line B: Trended EUIs with actual activity growth

Line C: Constant 1972 EUI with actual activity growth

Line D: Actual EUIs with trended growth

Line E: Trended EUI with trended activity growth

FIGURE E.1. Energy Savings Measured with Lines A - E 


\section{E.1.3 Energy Savings Due to Energy Efficiency Improvements Relative to Trends (Line $B$ - Line A).}

The difference between Line $B$ and Line $A$. is given by:

$$
\begin{aligned}
& \operatorname{EUB}(\mathrm{J})_{t}-\operatorname{EUA}(\mathrm{J})_{t}=\hat{E U I}(\mathrm{~J})_{t} \cdot x(\mathrm{~J})_{t}-\operatorname{EUI}(\mathrm{J})_{t} \cdot x(\mathrm{~J})_{t} \\
& =x(J)_{t} \cdot\left[E \hat{U I}(J)_{t}-E U I(J)_{t}\right]
\end{aligned}
$$

Since activity levels are the same for Lines $B$ and $A$ while the EUIs change from the trended level to the actually observed level, energy savings are ascribed to the additional changes in EUI from the trended to the actual levels.

\section{E.2 COMPUTING HISTORICAL GROWTH RATES OF EUIS AND ACTIVITIES}

To generate the energy-use values for Lines $B, D$, and $E$, historical data for EUIs and economic activities are required to estimate trended energy use intensity and trended economic activity. Such trends can be estimated from exponential, linear, or other appropriate specifications. When exponential growth is observed, semi-logarithmic regression can be applied to estimate the average annual rate of growth. The following general equation for the period from $t=1960$ to 1972 may be used to estimate growth rates for energy use intensities and economic activity:

$$
Y=a b^{t-1960}
$$

where $\quad Y$ is the specific variable under consideration, (e.g., EUI $(J)_{t}$ and

$$
\left.x(J)_{t}\right) \text {, }
$$

$t$ is time, from 1960-1972

$a$ and $b$ are estimated coefficients.

Generally, the parameter $b$ takes the following value:

$$
b=1+r_{Y}
$$

where $r_{Y}$ is the rate of change in variable $Y$. By substituting energy use intensities for $Y$ in Equation E.10 and regressing the equation, the annual growth rates of sector $\mathrm{J}$ energy use intensities, $\mathrm{rEUI}(\mathrm{J})$, may be derived. 
The procedure is similar for obtaining annual growth rates for economic activities in sector $\mathrm{J}$.

The advantage of using the semi-log regression is that the trend information is sumarized by the average annual rate of growth. The disadvantage, however, arises if some turning point occurs for the trend toward the end of the time period from which the growth rate was derived. The use of such a growth rate may lead to unrealistic values. Alternatively, linear or curvilinear trends can be used. For the economic activities and EUI series, the form in which the trend line is adopted depends upon the statistical properties of the regression runs. More importantly, however, it depends on historical trends; annual-growth rates derived by some specifications (e.g. nonlinear) may be superfluous.

\section{E.3 DERIVING TRENDED VALUES OF EUIS and ECONOMIC ACTIVITIES}

Given the average annual growth rates of energy ratios and activities, trended values for Lines B, D, and $E$ are derived by appropriately applying the following equations:

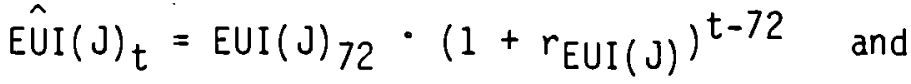

$$
\begin{aligned}
& \hat{x}(J)_{t}=x(J)_{72} \cdot\left(1+r_{x(J)}\right)^{t-72}
\end{aligned}
$$

to $\operatorname{EUI}(J)_{t}$ and $x(J)_{t}$.

If forms other than semi-log regression are used in determining the trend lines, then the respective trend equations would be applied.

\section{E.4 ECONOMY-WIDE AGGREGATIONS}

Summing up the results from four end-use sectors yields the economy-wide energy-use values and categories of energy savings:

$$
\begin{aligned}
& \text { Line } A: \operatorname{EUA}(T)_{t}=\sum_{J} \operatorname{EUA}(J)_{t} \\
& \text { Line B: } \operatorname{EUB}(T)_{t}=\sum_{J} \operatorname{EUB}(J)_{t} \\
& \text { Line C: } \operatorname{EUC}(T)_{t}=\sum \operatorname{EUC}(J)_{t}
\end{aligned}
$$




$$
\begin{aligned}
& \text { Line D: } \operatorname{EUD}(T)_{t}=\sum_{J} \operatorname{EUD}(J)_{t} \\
& \text { Line E: } \operatorname{EUE}(T)_{t}=\sum_{J} \operatorname{EUE}(J)_{t}
\end{aligned}
$$

where $T$ indicates total economy, and the summation is carried across all $\mathrm{J}$ sectors; i.e., residential (RC), commercial (CM), industrial (IN), and transportation (TR) sectors.

Similar to the above discussion relating to individual sectors in Section E.1, economy-wide energy savings can be categorized into the following:

Economic activity change energy savings:

$$
\operatorname{EUD}(T)_{t}-\operatorname{EUA}(T)_{t} \cdot \text { or } \operatorname{EUE}(T)_{t}-\operatorname{EUB}(T)_{t}
$$

Energy efficiency improvements since 1972:

$$
\operatorname{EUC}(T)_{t}-\operatorname{EUA}(T)_{t}
$$

Energy efficiency improvements relative to trends:

$$
\operatorname{EUB}(T)_{t}-\operatorname{EUA}(T)_{t}
$$

Alternatively, the energy saving measures for the total economy could be derived in a manner similar to that of the individual sectors by applying Equations E.2 through E.5 and using GNP as the activity variable; that is, rather than adding up individual sector results, total economy savings could be derived directly from energy consumption data for the entire economy. 


\section{APPENDIX $F$}

SUMMARY TABLES 
TABLE F.1. Estimated Energy Savings Due to Changes in Economic Activity: $1972-1982$ (a)(b) (quads of primary energy)

\section{1}

$$
\text { Residential Commercial Industrial }
$$

\begin{tabular}{c} 
Year \\
\hline 1972 \\
1973
\end{tabular}

(1)

0.0

$-0.035$

$-0.074$

$-0.066$

$-0.152$

$-0.136$

$-0.232$

$-0.338$

$-0.406$

$-0.401$

$-0.407$

$-2.247$

3.573

40.570

Percent of Total

Economy
$-4.87$

7.74

87.93
4.245

46.141

Economy

(4) $(1)+(2)+(3)+(4)$

0.0

$-1.050$

2.354

6.168

4.267

3.252

2.103

3.154

6.791

7.395

11.318

2.458

100.00

(a) Economic activity as defined for each sector:

Residential: Number of households

Commercial: Square feet of floor space in the commercial sector Industrial: Value added (billions of 1972 dollars)

Transportation: Weighted average of person-miles and ton-miles traveled.

(b) Estimated energy savings represents Line A minus Line D.

Source: Pacific Northwest Laboratory 
TABLE F.2. Estimated Energy Savings Due to Efficiency Improvements Relative to 1972 Stock: 1972-1982(a)(b)

$$
\text { (quads of primary energy) }
$$

\begin{tabular}{|c|c|c|c|c|c|}
\hline Year & $\begin{array}{l}\text { Residential } \\
\text { (1) } \\
\end{array}$ & $\frac{\text { Commercial }}{(2)}$ & $\begin{array}{c}\text { Industrial } \\
\text { (3) }\end{array}$ & $\begin{array}{l}\text { Transportation } \\
\text { (4) }\end{array}$ & $\begin{array}{c}\text { Economy } \\
(1)+(2)+(3)+(4)\end{array}$ \\
\hline 1972 & 0.0 & 0.0 & 0.0 & 0.0 & 0.0 \\
\hline 1973 & -0.055 & -0.004 & 0.876 & -0.098 & 0.719 \\
\hline 1974 & 0.795 & 0.482 & 0.339 & 0.067 & 1.683 \\
\hline 1975 & 0.990 & 0.628 & 0.729 & -0.201 & 2.146 \\
\hline 1976 & 0.824 & 0.279 & 1.222 & 0.426 & 2.751 \\
\hline 1977 & 0.901 & 0.389 & 2.365 & 0.679 & 4.334 \\
\hline 1978 & 0.894 & 0.393 & 3.697 & 1.293 & 6.277 \\
\hline 1979 & 1.779 & 0.602 & 3.420 & 1.681 & 7.482 \\
\hline 1980 & 2.286 & 0.893 & 3.910 & 1.817 & 8.906 \\
\hline 1981 & 3.113 & 1.126 & 6.386 & 2.053 & 12.678 \\
\hline 1982 & 3.236 & 1.129 & 7.414 & 2.152 & 13.931 \\
\hline $\begin{array}{l}\text { Cumulativ } \\
\text { Savings, } \\
1972-82\end{array}$ & 14.763 & 5.917 & 30.358 & 9.869 & 60.907 \\
\hline $\begin{array}{l}\text { Percent } \\
\text { of Total } \\
\text { Economy }\end{array}$ & 24.24 & 9.71 & 49.84 & 16.20 & 100.00 \\
\hline
\end{tabular}

(a) Efficiency immprovement is defined as decreases in Energy Use Intensity, which is defined for each end-use sector as quads of energy consumed divided by the appropriate measure of economic activity.

(b) Energy savings are defined relative to 1972 Energy Use Intensity. This represents Line A minus Line $C$.

Source: Pacific Northwest Laboratory 
TABLE F.3. Estimated Energy Savings Due to Efficiency Improvements Relative to 1960-1972 Trends: $1972-1982$ (a)(b)

$$
\text { (quads of primary energy) }
$$

\begin{tabular}{|c|c|c|c|c|c|}
\hline Year & $\begin{array}{l}\text { Residential } \\
\text { (1) }\end{array}$ & $\begin{array}{c}\text { Commercial } \\
(2)\end{array}$ & $\begin{array}{c}\text { Industrial } \\
(3)\end{array}$ & $\begin{array}{c}\text { Transportation } \\
(4)\end{array}$ & $\begin{array}{c}\text { Economy } \\
(1)+(2)+(3)+(4)\end{array}$ \\
\hline 1972 & 0.0 & 0.0 & 0.0 & 0.0 & 0.0 \\
\hline 1973 & 0.646 & 0.225 & 0.817 & -0.155 & 1.533 \\
\hline 1974 & 1.688 & 0.961 & 0.252 & -0.045 & 2.856 \\
\hline 1975 & 2.374 & 1.372 & 0.619 & -0.367 & 3.998 \\
\hline 1976 & 2.743 & 1.306 & 1.073 & 0.186 & 5.308 \\
\hline 1977 & 3.378 & 1.720 & 2.174 & 0.362 & 7.634 \\
\hline 1978 & 3.986 & 2.058 & 3.463 & 0.886 & 10.393 \\
\hline 1979 & 5.537 & 2.628 & 3.145 & 1.207 & 12.517 \\
\hline 1980 & 6.749 & 3.294 & 3.612 & 1.289 & 14.944 \\
\hline 1981 & 8.310 & 3.929 & 6.045 & 1.459 & 19.743 \\
\hline 1982 & 9.178 & 4.332 & 7.063 & 1.532 & 22.105 \\
\hline $\begin{array}{l}\text { Cumulativ } \\
\text { Savings, } \\
1972-82\end{array}$ & 44.589 & 21.825 & 28.263 & 6.354 & 101.031 \\
\hline $\begin{array}{l}\text { Percent } \\
\text { of Total } \\
\text { Economy }\end{array}$ & 44.13 & 21.60 & 27.97 & 6.29 & 100.00 \\
\hline
\end{tabular}

(a) Efficiency improvement is defined as decreases in Energy Use Intensity, which is defined for each end-use sector as quads of energy consumed divided by the appropriate measure of economic activity.

(b) Savings are defined relative to 1960-1972 trends in Energy Use Intensity (i.e., these trends are carried forward into the 1972-1982 period to determine savings). This represents Line $A$ minus Line $B$.

Source: Pacific Northwest Laboratory 
TABLE F.4. Alternative Estimates of Total Energy Use In the Total U.S. Economy, GNP Approach, 1972-1982

Trillion $\left(10^{12}\right)$ Btu

\begin{tabular}{llllll} 
Year & $\begin{array}{l}\text { Line } \\
A\end{array}$ & $\begin{array}{c}\text { Line } \\
B\end{array}$ & $\begin{array}{c}\text { Line } \\
C\end{array}$ & $\begin{array}{c}\text { Line } \\
D\end{array}$ & \multicolumn{1}{c}{ Line } \\
\cline { 6 - 7 } & & & & & \\
1972 & 71628 & 71628 & 71628 & 71628 & 71628 \\
1973 & 74602 & 76029 & 75801 & 73384 & 74787 \\
1974 & 72755 & 75832 & 75379 & 74917 & 78087 \\
1975 & 70709 & 75200 & 74527 & 76664 & 81532 \\
1976 & 74509 & 79491 & 78544 & 79798 & 85133 \\
1977 & 76335 & 84100 & 82850 & 80681 & 88889 \\
1978 & 78186 & 88362 & 86788 & 82120 & 92808 \\
1979 & 78903 & 91490 & 89591 & 83573 & 96905 \\
1980 & 76022 & 91604 & 89434 & 83970 & 101180 \\
1981 & 74014 & 93739 & 91209 & 83450 & 105646 \\
1982 & 70840 & 91924 & 89210 & 85004 & 110309
\end{tabular}

Line A: Actual energy use; actual Energy Use Intensities (EUIs) with actual activity growth

Line B: Trended EUIs with actual activity growth

Line C: Constant 1972 EUI with actual activity growth

Line D: Actual EUIs with trended activity growth

Line E: Trended EUIs with trended activity growth 
TABLE F.5. Alternative Estimates of Total Energy Use: Sum of Four Sectors, 1972-1982

\begin{tabular}{|c|c|c|c|c|c|}
\hline \multirow[b]{2}{*}{ Year } & \multicolumn{5}{|c|}{ Trillion $\left(10^{12}\right)$} \\
\hline & $\begin{array}{c}\text { Line } \\
\mathrm{A} \\
\end{array}$ & $\begin{array}{c}\text { Line } \\
\mathrm{B} \\
\end{array}$ & $\begin{array}{c}\text { Line } \\
C\end{array}$ & $\begin{array}{c}\text { Line } \\
D \\
\end{array}$ & $\underset{E}{\text { Line }}$ \\
\hline 1972 & 70858 & 70858 & 70858 & 70858 & 70858 \\
\hline 1973 & 73876 & 75409 & 74595 & 72826 . & 74343 \\
\hline 1974 & 72084 & 74940 & 73767 & 74438 & 77301 \\
\hline 1975 & 70130 & 74128 & 72276 & 76298 & 80384 \\
\hline 1976 & 73861 & 79169 & 76612 & 78128 & 83599 \\
\hline 1977 & 75811 & 83445 & 80145 & 79063 & 86950 \\
\hline 1978 & 77652 & 88045 & 83929 & 79755 & 90446 \\
\hline 1979 & 78125 & 90642 & 85607 & 81279 & 94093 \\
\hline 1980 & 75398 & 90342 & 84304 & 82189 & 97895 \\
\hline 1981 & 73371 & 93114 & 86049 & 80766 & 101864 \\
\hline 1982 & 70153 & 92258 & 84084 & 81471 & 106002 \\
\hline
\end{tabular}

Line A: Actual energy use; actual Energy Use Intensities (EUIs) with actual activity growth

Line B: Trended EUIs with actual activity growth

Line C: Constant 1972 EUI with actual activity growth

Line D: Actual EUIs with trended activity growth

Line E: Trended EUIs with trended activity growth 
TABLE F.6. Ratio of Alternative Estimates for Total Energy Use in the U.S. Economy: Sum-of-Four-Sector Approach versus Real Gross National Product Approach

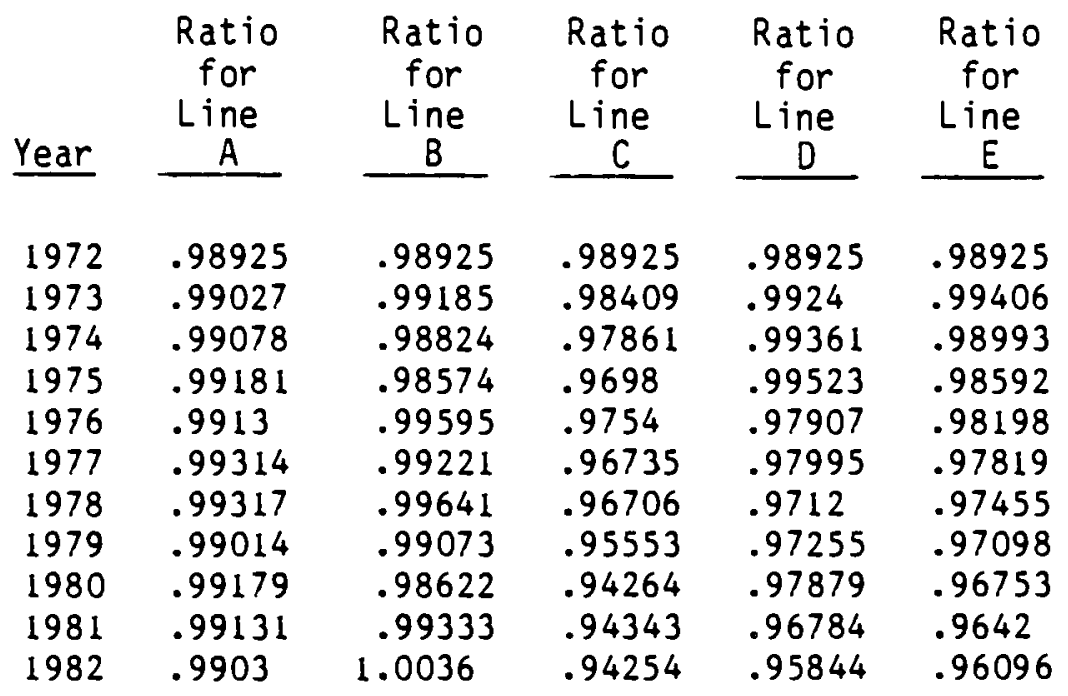

Sum of Four Sector Approach: Adding up the corresponding estimates for residential, commercial, industrial, and transportation sectors.

Real Gross National Product (GNP) Approach: Use the constraint dollar GNP as the activity variable to devise EUI, and then apply the same procedures as used in the sectoral analysis.

Ratios are computed as sum of four sectors over for each alternative estimate over the corresponding estimates from the real GNP approach. 


\section{DISTRIBUTION}

No. of

Copies

OFFSITE

Barry McNutt

DOE Office of Policy, Safety, and Environment

1000 Independence Avenue, S.W. Washington, DC 20585

Dr. Fred Abe 1

DOE Division of Conservation and Renewable Energy

1000 Independence Avenue, S.W. Washington, DC 20585

David Meyer

DOE Office of Policy, Safety, and Environment

1000 Independence Avenue, S.W. Washington, DC 20585

Bill White

DOE Office of Policy, Safety, and Environment

1000 Independence Avenue, S.W.

Washington, DC 20585

Dick Holt

DOE Office of Policy, Safety, and Environment

1000 Independence Avenue, S.W

Washington, DC 20585

John Corliss

c/o DOE Office of Policy, Safety, and Environment

1000 Independence Avenue, S.W.

Washington, DC 20585

Peggy Podolak

DOE Office of Policy Integration

1000 Independence Avenue, S.W.

Washington, DC 20585

30 DOE Technical Information Center
No. of

Copies

OFFSITE

David Lax

Energy and Environmental

Analys is, Inc.

1655 North Fort Myer Drive

Arlington, VA 22209

Arlene Wusterbarth

MITRE Corporation

1820 Dolley Madison Blvd.

McLean, VA 22101

ONSITE

DOE Richland Operations Office

H. E. Ransom

28 Pacific Northwest Laboratory

R. C. Adams (15)

D. B. Belzer

J. M. Fang

K. L. Imhoff

R. J. Moe

J. M. Roop

R. M. Scheer

Publishing Coordination (2)

Technical Information (5) 


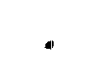

:

$+$

1 